UNIVERSIDAD POLITÉCNICA DE VALENCIA

Instituto Universitario de Ingeniería de Alimentos para el Desarrollo

\title{
EVALUATION OF ALTERNATIVES TO SYNTHETIC FUNGICIDES TO CONTROL CITRUS POSTHARVEST DISEASES
}

\author{
EVALUACIÓN DE ALTERNATIVAS A LOS FUNGICIDAS \\ SINTÉTICOS PARA EL CONTROL DE ENFERMEDADES DE \\ POSCOSECHA DE CÍTRICOS
}

\author{
TESIS DOCTORAL \\ Presentada por: \\ Clara Montesinos \\ DIRECTOR: \\ Dr. Lluís Palou \\ TUTORA: \\ Dra. Nuria Martínez Navarrete \\ Valencia, Diciembre 2015
}



Dr. Lluís Palou Vall, Investigador del Centro de Tecnología Poscosecha del Instituto Valenciano de Investigaciones Agrarias,

CERTIFICA: Que la memoria titulada "Evaluation of alternatives to synthetic fungicides to control citrus postharvest diseases", que, para aspirar al grado de Doctora en Ciencia, Tecnología y Gestión Alimentaria presenta D. Clara Montesinos, realizada bajo mi dirección en el Centro de Tecnología Poscosecha del Instituto Valenciano de Investigaciones Agrarias, cumple las condiciones adecuadas para su aceptación como Tesis Doctoral, por lo que

AUTORIZA: $\mathrm{Al}$ interesado a su presentación en el Instituto Universitario de Ingeniería de los Alimentos para el Desarollo de la Universidad Politécnica de Valencia.

Y para que conste a los efectos oportunos, presento $\mathrm{La}$ referida memoria, firmando el presente certificado en Valencia a Octubre de 2015.

Fdo. Dr. Lluís Palou Vall

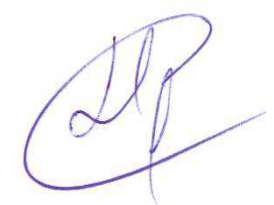



A mon pare, a qui tant extranye, qui m'enseyà qué es ser fort. Sempre estaràs en mi. A mi madre, nuestro pilar, que siempre está ahí y ha hecho posible, entre otras muchas cosas, que yo pueda escribir esta tesis. A mi noble y fantástica hermana, por compartir tanto conmigo y hacerlo todo más agradable. Y a mi hijo, por poner tanta alegría en mi vida, a quien espero poder trasladar los buenos valores que he recibido de mi familia. 

Two roads diverged in a yellow wood, And sorry I could not travel both And be one traveler, long I stood And looked down one as far as I could

To where it bent in the undergrowth;

Then took the other, as just as fair, And having perhaps the better claim, Because it was grassy and wanted wear; Though as for that the passing there Had worn them really about the same,

And both that morning equally lay In leaves no step had trodden black. Oh, I kept the first for another day! Yet knowing how way leads on to way, I doubted if I should ever come back.

I shall be telling this with a sigh Somewhere ages and ages hence: Two roads diverged in a wood, and I-

I took the one less traveled by, And that has made all the difference.

Robert Frost 



\section{AGRADECIMIENTOS}

Agraïsc al meu director de tesis, Dr. Lluís Palou per haver-me brindat l'oportunitat de realitzar el doctorat al seu grup d'investigació, per ensenyar-me tant, i per la seua professionalitat, dedicació i suport.

Al Dr. Miguel Angel del Río, que fue una persona entrañable y de grandes conocimientos, por sus consejos y amabilidad.

A la Dra. Núria Martínez por su colaboración como tutora académica.

A mis compañeros del IVIA, Aurora, Vero, Christian, Alicia, Cristina, con quienes he compartido tantas horas de laboratorio y oficina, por hacer esas horas tan amenas y sobretodo por vuestra amistad.

Al personal del Centro de Tecnología Poscosecha, con quien ha sido tan agradable trabajar y compartir esos almuerzos y comidas, Bernar, Sandra, Pilar, Cristina, Adela, Alicia, Sawsen, Pedro, Nacho, y todos los becarios, que han puesto su granito de arena.

To USDA staff in Parlier, California, specially to Joe Smilanick, who I've learned so much from and to whom I deeply admire for his intelligence and humbleness. Together with his family they made me feel like home.

To SARDI staff in Adelaide, Australia, mostly to Peter Taverner and Nancy Cunningham, for what they taught me with the best sense of humor.

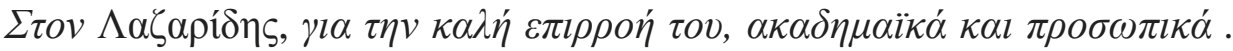

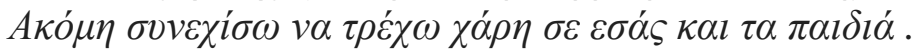

A mis amigas Isa, Mari, Sonia, Bea, Alicia, Marga, Eli... Magníficas! Por los buenos ratos y por vuestra amistad sincera.

A los amigos que he hecho a lo largo de mis estancias y trabajos en el extranjero, Giannis, Anthí, Judy, John, Franka, Delphine, Cruz, Vincenzo, David, Haihong, Hao, Burak, Hakan, y tantos más, por su amistad y por enriquecer tanto mi vida.

A mis actuales compañeros de trabajo, en especial Elena (de nuevo compañera), Carolina, Sergio... que también son amigos, por haberme acompañado en el último tramo de este proyecto. 
Especialmente, quiero dar las gracias a mi familia, desde mis abuelos hasta mi hijo, por ser un ejemplo de esfuerzo y por haberme motivado para crecer profesionalmente. 


Los cítricos (Citrus spp. fam. Rutaceae) son la fruta más consumida a nivel mundial y se cultivan en más de un centenar de países. Durante el manejo en poscosecha, la mayor parte de las pérdidas se deben a enfermedades fúngicas, que durante décadas se han controlado mediante tratamientos con fungicidas de síntesis. Sin embargo, su uso está continuamente más restringido por parte de los distribuidores y cadenas de supermercados, que reducen el Límite Máximo de Residuos (LMR) a un tercio del establecido o incluso prohíben el uso de ciertos fungicidas. Esto ha provocado la pérdida de eficacia de los tratamientos y el desarrollo de cepas de patógenos resistentes a los fungicidas. Se necesitan, pues, alternativas para sustituir o combinar con el uso de fungicidas de síntesis. El objetivo de este trabajo fue evaluar tratamientos alternativos contra las podredumbres verde y azul, causadas por Penicillium digitatum (Pers.: Fr.) Sacc. y Penicillium italicum Wehmer, respectivamente. Aditivos alimentarios y sustancias GRAS se probaron en ensayos in vivo preliminares contra los mohos verde y azul. El benzoato sódico (BS; Capítulo 1) y el sorbato potásico (SP; Capítulo 2) fueron los más eficaces. Baños de $60 \mathrm{~s}$ en $3 \%(\mathrm{p} / \mathrm{v}) \mathrm{BS}$ sobre $50^{\circ} \mathrm{C}$ redujeron en un $90 \%$ la incidencia de las podredumbres verde y azul en naranjas 'Valencia Late' tras 7 días a $20^{\circ} \mathrm{C}$. Estos tratamientos fueron también efectivos en naranjas 'Lanelate', limones 'Fino' y mandarinas híbridas 'Ortanique', pero no en mandarinas 'Clemenules'. La combinación de baños calientes de BS con dosis bajas de imazalil (IMZ) fueron sinérgicas. Esta combinación redujo la incidencia de las podredumbres verde y azul en casi el $100 \%$ en naranjas 'Valencia Late' tras 8 semanas a $5^{\circ} \mathrm{C}$ y 7 días a $20^{\circ} \mathrm{C}$. Baños de $\mathrm{SP}$ a $62^{\circ} \mathrm{C}$ durante 30 o $60 \mathrm{~s}$, redujeron las dos podredumbres en un 20, 25, 50, 80 o $95 \%$ en mandarinas 'Clemenules', 'Nadorcott', limones 'Fino', mandarinas 'Ortanique' o naranjas 'Valencia Late', respectivamente. Tras 60 días a $5^{\circ} \mathrm{C}$, las podredumbres verde y azul en naranjas 'Valencia Late' tratadas con SP a $62^{\circ} \mathrm{C}$ durante $60 \mathrm{~s}$ se redujeron en un 96 y $83 \%$, respectivamente. En ensayos semicomerciales con mandarinas 'Marisol', la combinación $\mathrm{SP}+\mathrm{IMZ}$ a $20^{\circ} \mathrm{C}$ permitió una bajada significativa de la dosis de IMZ sin perder eficacia contra la podredumbre verde. Un nuevo método colorimétrico que empleó la extracción del SP de la fruta macerada, seguido de una reacción con ácido 2-tiobabitúrico (Capítulo 3) mostró que en naranjas tratadas con SP almacenadas a $15^{\circ} \mathrm{C}$, los residuos 
descendieron rápidamente al inicio y lentamente más tarde, hasta que dejaron de descender tras 6 días. Un doble aclarado rápido con agua corriente inmediatamente después de la inmersión de limones en SP al $2 \%(\mathrm{p} / \mathrm{v})$, eliminó más del $90 \%$ del residuo de SP. El lavado con agua a presión (HPWW) un día tras el tratamiento con SP eliminó más del $73 \%$ del residuo de SP. Mandarinas 'Nadorcott', 'Clemenules' y 'Ortanique', y naranjas 'Valencia Late' se inocularon artificialmente, y se expusieron $24 \mathrm{~h}$ después a aire (control), 15, 30, 50 o $95 \mathrm{kPa} \mathrm{CO}$, o 30 o $45 \mathrm{kPa} \mathrm{O}_{2}$, a 20 o $33^{\circ} \mathrm{C}$ durante 8,24, o $48 \mathrm{~h}$, e incubadas a $20^{\circ} \mathrm{C}$ durante 4,7 o 15 días. Los choques gaseosos a $33^{\circ} \mathrm{C}$ y $15 \mathrm{kPa} \mathrm{CO}$ durante $24 \mathrm{~h}$ o $30 \mathrm{kPa}$ $\mathrm{O}_{2}$ durante $48 \mathrm{~h}$ controlaron de manera eficaz las podredumbres verde $\mathrm{y}$ azul tras 7 días de incubación a $20^{\circ} \mathrm{C}$, pero el control de las dos podredumbres descendió tras 15 días (Capítulo 4). La combinación de baños con SP y choques gaseosos mostró un efecto sinérgico, que mantuvo la eficacia de los tratamientos combinados durante 15 días. En almacenamiento en frío, tras 14, 28 y 42 días, la incidencia de moho verde en mandarinas 'Clemenules' y 'Ortanique' tratadas con baños con SP y $30 \mathrm{kPa} \mathrm{O}_{2}$ durante $48 \mathrm{~h}$ se redujo en un 100, 96 y 68\%, y 100, 97 y $79 \%$, respectivamente. De nuevo, una fuerte sinergia se observó entre los tratamientos (Capítulo 5). Las podredumbres verde y azul se controlaron eficazmente mediante la fumigación de limones y naranjas durante $6 \mathrm{~h}$ a $22^{\circ} \mathrm{C}$ con dos dosis de $3000 \mu \mathrm{L} \mathrm{L}^{-1}$ amoniaco, inyectadas al inicio del tratamiento y 2 h después (Capítulo 6). La fumigación de limones con $6000 \mu \mathrm{L} \mathrm{L}^{-1}$ amoniaco aceleró ligeramente la transición natural del color de la corteza de verde a amarillo. La germinación de esporas de $P$. italicum fue más sensible al amoniaco que la de las de $P$. digitatum. El tratamiento con amoniaco controló una cepa de $P$. digitatum resistente a IMZ. Cuando la fruta se bañó en 10 o $30 \mathrm{mg} \mathrm{L}^{-1} \mathrm{IMZ}$ (un $10 \%$ de la dosis comercial) antes de la fumigación con amoniaco, una sola aplicación con $1500 \mu \mathrm{L} \mathrm{L}^{-1}$ amoniaco fue suficiente para controlar las dos podredumbres, y el incremento en la eficacia fue aditivo o sinérgico. Todos estos tratamientos, a diferentes niveles, podrían sustituir a los fungicidas de síntesis o aumentar la eficacia de los tratamientos con IMZ en el manejo poscosecha de los cítricos. El desarrollo de las podredumbres verde y azul en las especies y variedades de cítricos más importantes comercialmente se evaluó durante cuatro campañas consecutivas y se relacionó con los parámetros de calidad de la fruta 
(Capítulo 7). La susceptibilidad de los cultivares en orden creciente fue 'Nova', 'Sanguinelli', 'Ortanique', 'Lanelate', 'Navelate', 'Fortune', 'Clemenules', 'Valencia Late', 'W. Navel', 'Oronules', 'Clemenpons', 'Marisol', 'Salustiana', 'Hernandina' y 'Nadorcott'. Las características de la corteza fueron los parámetros de calidad más correlacionados con la susceptibilidad de los cítricos a las podredumbres. 
Els cítrics (Citrus spp. fam. Rutaceae) son la fruita més consumida a nivell mundial i es cultiven en un centenar de països. Durant la postcollita, la major part de les pèrdues es deuen a malalties fúngiques, que durant dècades s'han controlat mitjançant tractaments amb fungicides de síntesi. No obstant, l'ús d'aquestes pràctiques està contínuament més restringit per part dels distribuïdors y cadenes de supermercats, que redueixen el Límit Màxim de Residus (LMR) a un terç del permès per la legislació o inclús prohibeixen l'ús d'alguns fungicides. Açò ha provocat la minora de l'eficàcia dels tractaments poscollita i el desenvolupament de soques dels patògens resistents als fungicides. Es necessari, per tant, trobar i implementar alternatives per substituir o combinar l'ús de fungicides de síntesi. L'objectiu d'aquest treball ha sigut avaluar tractaments alternatius contra les podridures verda i blava, causades per Penicillium digitatum (Pers.: Fr.) Sacc. i Penicillium italicum Wehmer, respectivament. Additius alimentaris i substàncies GRAS es provaren en proves in vivo preliminars contra les podridures verda i blava. El benzoat sòdic (BS; Capítol 1) i el sorbat potàsic (SP; Capítol 2) foren els més eficaços. Banys de $60 \mathrm{~s}$ en 3\% (p/v) BS sobre $50^{\circ} \mathrm{C}$ reduïren en un $90 \%$ la incidència de les podridures verda i blava en taronges 'Valencia Late' després de 7 dies a $20^{\circ} \mathrm{C}$. Estos tractaments foren també efectius en taronges 'Lanelate', llimones 'Fino' i mandarines híbrides 'Ortanique', però no en mandarines 'Clemenules'. Solucions calentes de BS combinades amb baixes dosis d'imazalil (IMZ) foren sinèrgiques. Esta combinació va reduir la incidència de les podridures verda i blava en quasi el $100 \%$ en taronges 'Valencia Late' després de 8 setmanes a $5^{\circ} \mathrm{C}$ i 7 dies a $20^{\circ} \mathrm{C}$. Els tractaments en banys de $\mathrm{SP}$ a $62^{\circ} \mathrm{C}$ durant 30 o $60 \mathrm{~s}$, reduïren les dos podridures en un 20, 25, 50, 80 o 95\% en mandarines 'Clemenules' i 'Nadorcott', llimones 'Fino', mandarines 'Ortanique' o taronges 'Valencia Late', respectivament. Després de 60 dies a $5^{\circ} \mathrm{C}$, les podridures verda i blava en taronges 'Valencia Late' tractades amb SP a $62^{\circ} \mathrm{C}$ durant $60 \mathrm{~s}$ se reduïren en un 96 i $83 \%$, respectivament. En assajos semicomercials amb mandarines 'Marisol', la combinació $\mathrm{SP}+\mathrm{IMZ}$ a $20^{\circ} \mathrm{C}$ va permetre una baixada significativa de la dosis de IMZ sense perdre eficàcia contra la podridura verda. Un nou mètode colorimètric que inclou l'extracció del SP de la fruita macerada, seguit d'una reacció amb àcid 2-tiobabitúric (Capítol 3) mostrà que en taronges tractades amb SP conservades a $15^{\circ} \mathrm{C}$, els residus descendiren 
ràpidament al inici i lentament mes tard, fins que deixaren de descendir després de 6 dies. Un doble rentat ràpid amb aigua corrent immediatament després de la immersió de llimones en SP al 2\% (p/v), eliminà més del $90 \%$ del residu de SP. El llavat en agua a pressió (HPWW) un dia després del tractament amb SP eliminà més del 73\% del residu de SP. Mandarines 'Nadorcott', 'Clemenules' i 'Ortanique', i taronges 'Valencia Late' s'inocularen artificialment i s'exposaren $24 \mathrm{~h}$ després a aire (control), 15, 30, 50 o $95 \mathrm{kPa} \mathrm{CO}_{2}$, o 30 o $45 \mathrm{kPa} \mathrm{O}_{2}$, a 20 o $33^{\circ} \mathrm{C}$ durant 8,24 , o $48 \mathrm{~h}$, i s'incubaren a $20^{\circ} \mathrm{C}$ durant 4,7 o 15 dies. Els xocs gasosos a $33^{\circ} \mathrm{C}$ i $15 \mathrm{kPa} \mathrm{CO}_{2}$ durant 24 h o $30 \mathrm{kPa} \mathrm{O}$ durant 48 $\mathrm{h}$ controlaren de manera eficaç les podridures verda $\mathrm{i}$ blava després de 7 dies d'incubació a $20^{\circ} \mathrm{C}$, però el control de les dos podridures descendí després de 15 dies (Capítol 4). La combinació de banys amb SP i xocs gasosos mostrà un efecte sinèrgic, que mantingué l'eficàcia dels tractaments combinats durant 15 dies. En conservacions en fred, després de 14,28 i 42 dies, d'incidència de podridura verda en mandarines 'Clemenules' i 'Ortanique' tractades en banys amb SP i 30kPa $\mathrm{O}_{2}$ durant 48h es reduí en un 100, 96 i 68\%, i 100, 97 i 79\%, respectivament. De nou, una forta sinergia s'observà entre els tractaments (Capítol 5). Les podridures verda i blava es controlaren eficaçment mitjançant la fumigació de llimones i taronges durant $6 \mathrm{~h}$ a $22^{\circ} \mathrm{C}$ amb dos dosis de $3000 \mu \mathrm{L} \mathrm{L}^{-1}$ amoníac, injectades a l'inici del tractament i $2 \mathrm{~h}$ després (Capítol 6). La fumigació de llimones amb $6000 \mu \mathrm{L} \mathrm{L}^{-1}$ amoníac accelerà lleugerament la transició natural del color de la pell de verd a groc. La germinació d'espores de $P$. italicum va ser més sensible a l'amoníac que la de les de $P$. digitatum. El tractament amb amoníac controlà una soca de $P$. digitatum amb un alt nivell de resistència a IMZ. Quan la fruita es banyà en 10 o $30 \mathrm{mg} \mathrm{L}^{-1} \mathrm{IMZ}$ (un $10 \%$ de la dosis comercial) abans de la fumigació amb amoníac, una sola aplicació amb $1500 \mu \mathrm{L} \mathrm{L}^{-1}$ amoníac fou suficient per controlar les dos podridures, i l'increment de l'eficàcia fou additiu o sinèrgic. Tots estos tractaments, a diferents nivells, podrien substituir als fungicides de síntesis o augmentar l'eficàcia dels tractaments amb IMZ en el maneig postcollita dels cítrics. El desenvolupament de les podridures verda i blava en les espècies $i$ varietats de cítrics més importants comercialment s'avaluà durant quatre campanyes consecutives i es relacionà amb els paràmetres de qualitat de la fruita (Capítol 7). La susceptibilitat dels distints cultivars en ordre 
creixent fou 'Nova', 'Sanguinelli', 'Ortanique', 'Lanelate', 'Navelate', 'Fortune', 'Clemenules', 'Valencia Late', 'W. Navel', 'Oronules', 'Clemenpons', 'Marisol', 'Salustiana', 'Hernandina' i 'Nadorcott'. Les característiques de la pell foren els paràmetres de qualitat més influents en la susceptibilitat dels cítrics a les podridures. 
Citrus spp. (Rutaceae) are the most widely produced fruits and they are grown in over a hundred countries. During postharvest, major losses are caused by fungal diseases, which for decades have been controlled with synthetic fungicides. However, their use is increasingly restricted by distributors and supermarket chains, which can lower the Maximum Residue Level (MRL) to one third of the authorized levels or even ban the use of certain fungicides. This has led to loss of efficacy of treatments and development of resistant strains of the pathogens. Alternatives are necessary to substitute or combine the use of synthetic fungicides. The objective of the present work was to evaluate alternative treatments against green and blue molds, caused by Penicillium digitatum (Pers.: Fr.) Sacc. and Penicillium italicum Wehmer, respectively. Food additives and GRAS substances were tested in in vivo preliminary tests against green and blue molds. Sodium benzoate (SB) (Chapter 1) and potassium sorbate (PS) (Chapter 2) were the most effective. Sixty-second dips in $3 \%(\mathrm{w} / \mathrm{v}) \mathrm{SB}$ above $50^{\circ} \mathrm{C}$ reduced green and blue mold incidence by $90 \%$ on 'Valencia' oranges after 7 days at $20^{\circ} \mathrm{C}$. This treatment was also effective on 'Lanelate' oranges, 'Fino' lemons and 'Ortanique' mandarins, but not on 'Clemenules' mandarins. Heated solutions combining SB with low doses of imazalil (IMZ) were synergistic. This combination reduced the incidence of green and blue molds almost by $100 \%$ on 'Valencia' oranges after 8 weeks at $5^{\circ} \mathrm{C}$ and 7 days at $20^{\circ} \mathrm{C}$. PS applications at $62^{\circ} \mathrm{C}$ for 30 or $60 \mathrm{~s}$, reduced both penicillium molds by up to $20,25,50,80$, or $95 \%$ on 'Clemenules' and 'Nadorcott' mandarins, 'Fino' lemons, 'Ortanique' mandarins, and 'Valencia' oranges, respectively. After 60 days storage at $5^{\circ} \mathrm{C}$, green and blue molds on 'Valencia' oranges treated with PS at $62^{\circ} \mathrm{C}$ for $60 \mathrm{~s}$ were reduced by 96 and $83 \%$, respectively. In semi-commercial trials with 'Marisol' clementine mandarins, the combination PS+IMZ at $20^{\circ} \mathrm{C}$ allowed a significant reduction of IMZ doses without losing effectiveness on the control of green mold. A new colorimetric method that employed extraction of PS from macerated fruit, followed by reaction with 2thiobarbituric acid (Chapter 3) showed that in oranges treated with PS and stored at $15^{\circ} \mathrm{C}$, residues declined initially rapidly and later more slowly, until residues stopped declining after 6 days. A brief double-dip rinse in tap water, immediately after immersion of lemons in a $2 \%(\mathrm{w} / \mathrm{v})$ PS solution, removed more than $90 \%$ of PS residue. High pressure water 
washing (HPWW) 1 day after PS treatment, removed more than $73 \%$ of the PS residue. 'Nadorcott', 'Clemenules' and 'Ortanique' mandarins, and 'Valencia' oranges were artificially inoculated, exposed $24 \mathrm{~h}$ later to air (control), $15,30,50$, or $95 \mathrm{kPa} \mathrm{CO}_{2}$, or 30 or $45 \mathrm{kPa} \mathrm{O}$, at 20 or $33^{\circ} \mathrm{C}$ for 8,24 , or $48 \mathrm{~h}$, and incubated at $20^{\circ} \mathrm{C}$ for 4,7 , or 15 days. Exposure at $33^{\circ} \mathrm{C}$ with $15 \mathrm{kPa} \mathrm{CO}$ for $24 \mathrm{~h}$ or $30 \mathrm{kPa} \mathrm{O}_{2}$ for $48 \mathrm{~h}$ effectively controlled both green and blue molds after 7 days of incubation at $20^{\circ} \mathrm{C}$, but control of both diseases was lower after 15 days (Chapter 4). Combining PS dip treatments with gas exposure showed a synergistic effect that maintained the efficacy of combined treatments during 15 days. After 14, 28, and 42 days of cold storage, green mold incidence on 'Clemenules' and 'Ortanique' mandarins treated with PS dips and $30 \mathrm{kPa}$ $\mathrm{O}_{2}$ for $48 \mathrm{~h}$ was reduced by 100, 96 and 68\%, and 100, 97 and $79 \%$, respectively. Again, a synergistic effect between treatments was observed (Chapter 5). Postharvest green and blue molds were effectively controlled by fumigation of lemons and oranges for $6 \mathrm{~h}$ at $22^{\circ} \mathrm{C}$ with two applied dosages of $3000 \mu \mathrm{L} \mathrm{L}^{-1}$ of ammonia that was injected initially and again $2 \mathrm{~h}$ later (Chapter 6). Fumigation of lemons with $6000 \mu \mathrm{L} \mathrm{L}^{-1}$ of ammonia slightly accelerated the natural transition of rind color from green to yellow. The germination of spores of $P$. italicum was more sensitive to ammonia than that of spores of $P$. digitatum. Ammonia fumigation controlled an IMZ-resistant isolate of $P$. digitatum. When fruit were first immersed in 10 or $30 \mathrm{mg} \mathrm{L}^{-1} \mathrm{IMZ}$ (about $10 \%$ of typical commercial rates) before ammonia fumigation, a single fumigation with $1500 \mu \mathrm{L} \mathrm{L}^{-1}$ of ammonia was adequate to control both diseases and the increase in effectiveness was additive or synergistic. All these treatments, at different degrees, could replace synthetic fungicides or augment IMZ performance in citrus postharvest decay management. The development of green and blue molds on the most commercially important citrus species and cultivars was assessed for four consecutive harvest seasons and associated with fruit quality parameters (Chapter 7). Fruit susceptibility of the cultivars to green mold in increasing order was 'Nova', 'Sanguinelli', 'Ortanique', 'Lanelate', 'Navelate', 'Fortune', 'Clemenules', 'Valencia', 'W. Navel', 'Oronules', 'Clemenpons', 'Marisol', 'Salustiana', 'Hernandina' and 'Nadorcott'. Peel characteristics were the most influencing quality parameters on the susceptibility of citrus fruit to green and blue molds. 


\section{INDEX}

\section{Summaries}

Castellano ........................................................... 1

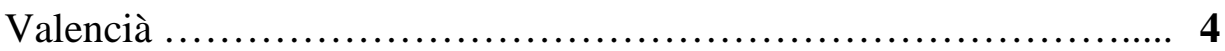

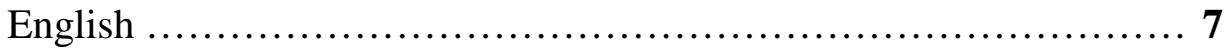

General Introduction .......................................................................................... 11

Combination of physical and low-toxicity chemical postharvest treatments for integrated disease management of citrus fruit: a review

Reference: Updated versión of Stewart Postharvest Review, 2010. Volume 6, Number 1, pp. 1-11.

General Objectives

Chapter 1

Evaluation of sodium benzoate and other food additives for the control of citrus postharvest green and blue molds

Reference: Postharvest Biology and Technology 2016, 115, 72-80.

Chapter 2 79

Evaluation of brief potassium sorbate dips to control postharvest penicillium decay on major citrus species and cultivars

Reference: Postharvest Biology and Technology 2009, 52, 117-125.

Chapter 3

Potassium sorbate residue levels and persistence in citrus fruit as detected by a simple colorimetric method

Reference: Journal of Agricultural and Food Chemistry 2009, 57, 34583463 . 
Short exposure to high $\mathrm{CO}_{2}$ and $\mathrm{O}_{2}$ at curing temperature to control postharvest diseases of citrus fruit

Reference: Plant Disease 2012, 96, 423-430.

Chapter 5

Synergism between potassium sorbate dips and short gas exposures at curing temperatures for zero residue control of green and blue molds in citrus postharvest

Reference: Crop Protection 2016, 81, 43-46.

Chapter 6 165

Control of citrus postharvest decay by ammonia gas fumigation and its influence on the efficacy of the fungicide imazalil

Reference: Postharvest Biology and Technology 2011, 59, 85-93.

Chapter 7

Relative susceptibility of major commercial orange and mandarin cultivars to postharvest green and blue molds and its relationship with fruit quality attributes

Reference: Prepared for submission.

General Discussion 
GENERAL INTRODUCTION 



\title{
Combination of physical and low-toxicity chemical postharvest treatments for integrated disease management of citrus fruit: a review
}

\author{
CLARA MONTESINOS-HERRERO and LLUÍS PALOU \\ Laboratori de Patologia, Centre de Tecnologia Postcollita (CTP) \\ Institut Valencià d'Investigacions Agràries (IVIA) \\ Apartat Oficial, 46113 Montcada, València, Spain
}

Reference: Updated version of Stewart Postharvest Review, 2010. Volume 6, Number 1, pp. 1-11. 


\begin{abstract}
Purpose of the review: Numerous physical and low-toxicity chemical treatments and their combinations have been evaluated to replace the common synthetic fungicides used to control green and blue moulds and sour rot, the most economically important postharvest diseases of citrus fruit. Although general or more specific research on this subject has been reviewed, new findings are reported every day because of the increasing interest and the large volume of research work devoted to the establishment of suitable integrated disease management (IDM) programs. The present review summarises the knowledge in this topic, giving emphasis to the most recent research results and conclusions.

Findings: Extensive research about combined physical and low-toxicity chemical treatments shows that the substitution of synthetic fungicides, or an important reduction in their required doses, by alternative treatments is currently feasible. In order to achieve an efficacy level commercially acceptable, these postharvest non-polluting alternative treatments need to be incorporated into IDM programs that also consider a variety of good practices to be followed from the field to the market.

Limitations: Even when combined, physical and low-toxicity chemical treatments may lack the persistence and preventive action of conventional fungicides and their effectiveness against established fungal infections highly depends on the species, cultivar and fruit physical and physiological condition. High costs, excessive duration or other technological application problems are drawbacks of some effective alternative treatments when compared to the use of chemical fungicides. These handicaps difficult the broad commercial replacement of common fungicides by non-toxic alternatives in citrus postharvest management.

Directions for future research: Ongoing research about host-pathogen interactions, new and more effective alternative treatments and the effects of these treatments on biochemical and molecular responses of fruits and pathogens is improving the efficacy of alternative treatments and their commercial applicability. In order to completely rely on alternative methods, there is a need to establish specific and optimised non-polluting IDM programs.
\end{abstract}


Keywords: Penicillium digitatum, P. italicum, Geotrichum citri-aurantii, green mould, blue mould, sour rot, integrated disease management, GRAS, heat, antifungal edible coatings.

\section{Introduction}

Citrus fruit are the highest value fruit crop in terms of international trade. Over 123 million tones are produced annually in 140 countries, of which Spain is the leading producing country for fresh consumption (FAO, 2013). Postharvest decay of citrus fruit limits the length of time fruit can be stored, compromises marketing acceptability, and causes substantial produce losses. The most economically important postharvest diseases that affect citrus fruit from arid climates are green and blue moulds and sour rot, caused by Penicillium digitatum (Pers.:Fr.) Sacc., Penicillium italicum Wehmer, and Geotrichum citri-aurantii (Ferraris) E.E. Butler, respectively. Among these wound pathogens, green and blue moulds account for most of the citrus decay, while sour rot can rapidly spread and be disastrous on fruit stored at temperatures above $10^{\circ} \mathrm{C}$. Fresh produce losses due to disease vary between citrus growing regions and are often 10-20\%; however, under favourable disease conditions, losses up to $50 \%$ can occur during marketing (Abd-El-Aziz and Mansour, 2006). For many years, citrus postharvest diseases have been primarily controlled worldwide by the application of conventional synthetic fungicides such as sodium ortho-phenyl phenate (SOPP), thiabendazole (TBZ), or imazalil (IMZ) (Smilanick et al., 2006; Palou, 2014). Geotrichum citri-aurantii, however, is resistant to TBZ and IMZ (Schachnai and Barash, 1982) and can only be controlled to some extent by applications of SOPP or guazatine, which use is restricted in many countries (Brown, 1979; Kitagawa and Kawada, 1984; Cunningham and Taverner, 2007). The application of conventional fungicides may reduce the losses due to decay to 2-4\% (Naqvi, 2004; Smilanick et al., 2006). However, the continuous use of a reduced number of chemicals has led to the development of resistant strains of the pathogens and a consequent loss of effectiveness of the fungicides (Kinay et al., 2007). New synthetic fungicides such as azoxystrobin (AZX), fludioxonil (FLU), pyrimethanil (PYR), or trifloxystrobin (TFX), have been tested in Europe and the USA (Schirra et al., 2004; Kanetis et al., 2007; D’Aquino et al., 2013b) and 
some of them are already in use in commercial packinghouses. Nevertheless, there are growing health and environmental concerns over pesticide disposal and fruit residue levels and, in many of the citrus importing countries, legislations, distribution and retail companies, and consumer associations are more restrictive every day regarding the amount of toxic residues present in the fruit. Likewise, the world market for certified organic citrus (fresh fruit and juice) demanding sustainable, environmentally friendly, ecological, or green agricultural produce is expected to rise steadily in developed countries, providing interesting export opportunities for producers in these higher-value markets (FAO, 2003). There is, therefore, an increasing need to find alternative strategies to control postharvest diseases that maintain a similar efficacy to that of synthetic fungicides but pose no risk to human health and environment. In order to become successful, strategies should take into consideration preharvest factors, harvest and transport conditions, and especially postharvest procedures as part of an integrated disease management (IDM) program (Narayanasamy, 2006; Palou et al., 2008). Some of the actions to take during postharvest handling include inoculum reduction through sanitation of the packinghouses and exclusion of decayed fruit (Bancroft et al., 1984), the use of suitable non-polluting antifungal treatments, and appropriate practices during fruit handling and storage to maintain or induce fruit resistance to fungal infection (Smilanick et al., 2006). Good practices in the packinghouses include hygiene and use of chemical sanitizers in dip tanks or re-circulating washes to destroy accumulated pathogenic spores and prevent them from washing on the otherwise healthy fruit tissue. However, sanitizers have no residual effects and wounded fruit may rot during transit and storage, resulting in a new focus of disease to adjacent fruit (Brown and Eckert, 2000a; Brown and Eckert, 2000b). The most important requirement of alternative antifungal postharvest treatments is that they must be costeffective and provide consistent disease control under commercial conditions. During decades, the purpose of many studies has been to find physical, chemical, or biological treatments capable to replace synthetic fungicides in citrus postharvest applications. Several comprehensive reviews and compilations have covered general or more specific aspects of this subject (Smilanick et al., 2006; Mari et al., 2007; Troncoso-Rojas et al., 2007; Palou et al., 2008; Bertolini, 2008; Palou, 2009, 2014), but 
new findings are being reported every day because of the increasing interest and the large volume of research devoted to the establishment of suitable IDM programs. The present review do not cover biological control strategies and focuses on general and recent research work on physical and low-toxicity chemical methods and their combinations as alternatives to conventional fungicides for the control of postharvest green and blue moulds and sour rot of citrus fruit.

\section{Individually applied physical or low-toxicity chemical treatments}

Physical treatments include the application of heat, irradiation, or storage strategies at low temperatures or in modified atmospheres, among others. The main advantages of physical treatments are that they leave no residues on fruit and their impact on the environment is negligible and only referred to the use of energy. The exposure of citrus fruit to various physical stresses such as injury (Brown et al., 1987), heat (Kim et al., 1991; Ben-Yehoshua et al., 1992) gamma radiation (Ladaniya et al., 2003) or far ultraviolet light (UV-C) (Ben-Yehoshua et al., 1992, Kuniga et al., 2006) may result in induction of antifungal compounds in the fruit peel that have been associated with the development of resistance against fungal pathogens. For instance, the coumarins scoparone and 4-(3methyl-2-butenoxy)isonitrosoacetophenone were isolated from gammairradiated orange and grapefruit peel (Riov, 1971; Dubery et al., 1988), while scoparone was not found in non-irradiated fruit. Accumulation of scoparone to fungitoxic levels in lemon peel was also reported following exposure to UV-C (Kuniga et al., 2006). Exposure of grapefruit to UV-C illumination resulted in induced resistance to P. digitatum (Droby et al., 1993), but some effective doses caused fruit injury (Kinay et al., 2005). It has been recently reported that blue light at wavelengths from 390 to 500 $\mathrm{nm}$ and intensity of $40 \mu \mathrm{mol} / \mathrm{m}^{2}$ s reduced decay caused by $P$. digitatum in tangerines (Alférez et al., 2012). Further work showed that blue light significantly reduced the activity of polygalacturonase in $P$. digitatum and $P$. italicum and induced the accumulation of octanal in the flavedo (Liao et al., 2013). Treatments with gaseous ozone or ozonated water, which leave no residue in fruit, have been tested in vitro with good results against $P$. digitatum and $G$. citri-aurantii; however, these treatments failed to control infections already established in the fruit 
before ozone treatment (Karaca and Sedat Velioglu, 2007; Palou et al., 2007). Cold storage is one of the most widely used technologies to slow respiration and other metabolic processes in order to preserve postharvest life of horticultural products (Wang, 1994). It is therefore a complementary decay control method that has a fungistatic activity but not a curative effect.

Special reference is due to heat treatments, including hot-water dips, vapour heat and forced hot air, which have been used for many years as non-chemical methods to control fungal decay in various fruits and vegetables (Barkai-Golan and Phillips, 1991; Lurie, 1998). In the particular case of citrus fruit, the heat applications evaluated more often for fungal decay control have been curing, hot water dips, and hot water rinsing and brushing. Thermal curing of citrus fruit consists of holding fruit for 2-3 days after harvest at temperatures higher that $30^{\circ} \mathrm{C}$ and above $90 \%$ relative humidity (RH). These conditions elicit the biosynthesis of antifungal compounds, phytoalexins and lignin-like materials in the flavedo of the fruit, enhancing the natural mechanisms of fruit resistance to fungal infections, while at the same time, the treatment directly reduces the growth of the pathogen (Rodov et al., 1995; Schirra et al., 2000). In some studies, very high or complete penicillium decay control was achieved by curing (Erkan et al., 2005), but other citrus postharvest diseases like sour rot were not effectively controlled. Holding mandarins at $40^{\circ} \mathrm{C}$ during the first 24 hours of degreening reduced by more that $95 \%$ the incidence of green and blue moulds on both early and late harvested fruit, but sour rot incidence reduction was only significant on late harvested mandarins. In general, curing delayed the degreening process and reduced the quality of the fruit (Plaza et al., 2004). Curing remains difficult to couple with standard management practices in citrus packinghouses. Too prolonged fruit treatments are not economically feasible and could induce unacceptable weight losses, which are directly responsible for the reduction of the fruit postharvest life. Reducing the duration and slightly increasing the temperature of the treatments is an approach that has been tested to increase the compatibility with commercial practices (Nunes et al., 2007). Hot water dips of citrus fruit to control decay were first reported in 1922 (Fawcett, 1922). This technology was presented as easier, cheaper, and more readily applicable 
by the industry than curing, since water is more efficient in heat-transfer than air (Wang et al., 2001), which allowed to reduce treatment duration. From the initial studies, the trend in tested treatments was to reduce the dip duration and increase the temperature of the water. Therefore, studies have subsequently tested treatment conditions from $50^{\circ} \mathrm{C}$ for $5 \mathrm{~min}$ (Spalding and Reeder, 1985) to $50-60^{\circ} \mathrm{C}$ for $20-150$ s (Schirra et al., 1998; Palou et al., 2001; Hong et al., 2007). Generally, lower temperatures were inefficient, while higher temperatures were phytotoxic (Schirra et al., 2000; Palou et al., 2001). However, both treatment efficacy and phytotoxicity depended on citrus species and cultivar (Palou et al., 2001) and fruit maturity at harvest (Schirra et al., 1998). The low persistence and curative activity against existing infections and technological issues related to the required dip tank size and energy costs have greatly limited the use of hot water dips as stand-alone treatments. A new technology based on hot water rinsing and brushing introduced an improvement to the method (Fallik, 2004). Treating citrus fruit with hot water rinsing and brushing at temperatures of 56 or $60^{\circ} \mathrm{C}$ for 20 or $10 \mathrm{~s}$, respectively, reduced postharvest diseases without injuring the fruit (Porat et al., 2000a; Rodov et al., 2000) and induced resistance to $P$. digitatum in grapefruits (Porat et al., 2000b). Nevertheless, although the method satisfactorily controlled green and blue moulds, it failed to control sour rot (Smilanick et al., 2003). Although commercially available in some countries, the use of hot water rinsing and brushing without any fungicide is limited to small fruit like kumquat, whose peel is also eaten, or some organically-grown fruit (Smilanick et al., 2005).

Alternative chemical treatments to substitute synthetic fungicides include the use of food additives, substances listed as generally regarded as safe (GRAS) by the United States Food and Drug Administration (FDA), and other natural compounds that pose no risk of toxicity to consumers or environment. Carbonates have been the most common food preservatives used in solutions to treat oranges and lemons in packinghouses in California, with no use restrictions even for organic agriculture (Smilanick et al., 1995, 1999; Dore et al., 2010). Other low-toxicity chemicals tested included aqueous solutions of sodium propionate (SP), sodium benzoate (SB), potassium sorbate (PS) (Palou et al., 2002a; Smilanick et al., 2008; Montesinos-Herrero et al., 2009a,b), or $\beta$ - 
aminobutyric acid (Tavallali et al., 2008), and acetic acid applied as fumigant (D'Aquino et al., 2008). Recently, the use of aqueous solutions of potassium silicate (Moscoso-Ramírez and Palou, 2014) or sodium paraben salts (Moscoso-Ramírez et al., 2013a,b, 2014) for the control of both green and blue molds has been investigated. The mode of action of these substances was not completely explained, although $\mathrm{pH}$ alterations in rind wounds, the presence of sodium cations, and further factors such as the induction of resistance mechanisms appear to be involved (Smilanick et al., 1999; Venditti et al., 2005). Generally, treatments by dipping the fruit in aqueous solutions of food additives were more effective when the solutions were heated, and the antifungal effect of these treatments lacked persistence (Palou et al., 2001; MontesinosHerrero et al., 2009a; Lesar, 2008; Smilanick et al., 2008). A large list of essential oils obtained from plants and other peel components presented in vitro antifungal activity against citrus postharvest pathogens (Caccioni et al., 1998; Ben-Yehoshua and Rodov, 2006; Yahyazadeh et al., 2008; Linde et al., 2010). Furthermore, in vivo tests confirmed the antifungal activity of some of these compounds by significantly suppressing fungal pathogen development on treated citrus fruit (Del Río and Ortuño, 2004; Salamone et al., 2008; Liu et al., 2009). Some plant extracts, especially from some Asian or African countries, presented a significant activity against $P$. digitatum, $P$. italicum, or $G$. citri-aurantii; for instance, this is the case of Aloe Vera (Saks and Barkai-Golan, 1995), garlic (Obagwu and Korsten, 2003), Huamuchil (Barrera-Necha et al., 2003), Thymus sp., Eucaliptus sp., Cistus sp., Juglans sp., Myrtus sp. (Ameziane et al., 2007), Accacia sp., Whitania sp., (Mekbib et al., 2007, 2009), or Lippia sp. (Combrinck et al., 2009; Shikanga et al., 2009), and many others (Palou et al., 2008; Tayel et al., 2009; Askarne et al., 2013; Zapata et al., 2013). Although in in vitro studies the direct toxic effects of these natural compounds against the pathogens have been repeatedly observed, results from in vivo research sometimes showed inefficacy or phytotoxicity (Plaza et al., 2004; Tripathi et al., 2004; Ameziane et al., 2007; Szczerbanik et al., 2007; Palou et al., 2011). In contrast, good inhibition of blue mold was obtained with the GRAS-registered essential oil MO-1 applied for $24 \mathrm{~h}$ in a gas phase (Ben-Arie et al., 2011). Some peptides and small proteins produced by plants or animals have been characterised and tested for the control of green and blue moulds with promising 
results (Muñoz and Marcos, 2006; Muñoz et al., 2007). Chitosan derivates from chitin present in crustacean shells, insect cuticles and fungal cell walls have been also tested for its antifungal activity against citrus postharvest pathogens (Wu et al., 2005; Ligorio et al., 2008).

\section{Combination of physical and low-toxicity chemical treatments}

For general acceptance by the industry, the efficacy of alternative treatments needs to be comparable to the level of control provided by conventional fungicides. Although different alternative approaches have been shown to reduce postharvest rots to some extend, they exhibit limitations that can affect their commercial applicability as stand-alone treatments. Therefore, the use of an integrated rather than a single approach is advocated in order to offer a consistent level of cost-effective disease control. In this regard, every day more studies are focusing on the combination of two or more existing alternative treatments to augment their individual performance. In general, three different objectives may be pursued by the combination of treatments: additive or synergistic effects to increase the efficacy and/or the persistence of individual treatments, complementary effects to combine preventive and curative modes of action, and commercial application of effective treatments that are too impractical, costly or risky as single treatments.

The most common combinations of alternative treatments that have been assayed to control citrus postharvest decay include heat as one of the components, combined with either other physical treatments or some alternative chemical treatments. Some heat treatments were cheap and easy to apply and often provided synergistic effects with other complementary postharvest decay control treatments. Several studies combined heat with different ionising irradiation technologies, GRAS compounds or low doses of synthetic fungicides. Other work assessed the integration of other physical or non-polluting chemical methods with the application of low-toxicity antifungal chemicals. Very recently, interest has risen for the development of antifungal edible coatings for citrus fruit. These different approaches are described in the following subsections, where their main advantages and limitations are discussed. 


\section{Combination of heat with other physical treatments}

Heat has been a common tool in the decay control arsenal of citrus fruit. However, the required conditions to control fungal pathogens with heated air treatments like curing applied alone are usually impractical, difficult to adopt and dangerous because of the risk of fruit damage caused by high temperatures. Attempts to reduce curing time, and consequently costs and risks, led to test citrus fruit brief exposure to carbon dioxide $\left(\mathrm{CO}_{2}\right)$ and/or oxygen $\left(\mathrm{O}_{2}\right)$ at curing temperatures (Palou et al., 2008; Montesinos-Herrero et al., 2010). After incubation at $20^{\circ} \mathrm{C}$ for 7 days, green mould incidence was reduced by about $70 \%$ on artificially inoculated 'Ortanique' mandarins treated at $33^{\circ} \mathrm{C}$ for 24 hours with 15 $\mathrm{kPa}$ of $\mathrm{CO}_{2}$. However, the reduction effect was lower as the incubation time was prolonged (Palou et al., 2008). Treatments with $30 \mathrm{kPa} \mathrm{O}_{2}$ at $33^{\circ} \mathrm{C}$ for 48 hours completely controlled green and blue moulds after 3 days of incubation, and reduced their incidence by 95 and $90 \%$ after 7 days, but only by 25 and $10 \%$, respectively, after 14 days. Therefore, the effect of such short $\mathrm{CO}_{2}$ or $\mathrm{O}_{2}$ treatments at $33^{\circ} \mathrm{C}$ was mainly fungistatic and lacked persistence (Palou et al., 2008; Montesinos-Herrero et al., 2010). Moreover, we observed that mandarins treated with $15 \mathrm{kPa} \mathrm{CO}_{2}$ at $33^{\circ} \mathrm{C}$ for 48 hours or 'Valencia' oranges exposed to $30 \mathrm{KPa} \mathrm{O}$ for 48 hours lost less weight than control fruit kept in air (Montesinos-Herrero et al., 2012).

Heat treatments have been applied to citrus combined with plastic packaging to maintain fruit quality. Individual sealing of citrus fruit in plastic films reduced the desiccation of fruit due to the curing treatment by reducing fruit transpiration and maintaining rind firmness (BenYehoshua et al., 1987). Benefits from these combinations, however, did not compensate their elevated costs. Both hot drench brushing at $60^{\circ} \mathrm{C}$ and hot water dip at $52^{\circ} \mathrm{C}$ delayed fruit softening, reduced the abscission of buttons, and preserved rind colour during curing applications (Rodov et al., 2000). Combined heat and UV-C treatments reduced decay and maintained quality of mandarins (Ben-Yehoshua, 2003), kumquats and 'Washington Navel' oranges better than either treatment alone (BenYehoshua et al., 2005). These researchers found that heat treatment followed by UV-C illumination was the most effective combination to control postharvest decay. Hot water dips or hot air curing significantly 
reduced the damage induced by subsequent severe UV-C treatments. When UV-C light was applied before heat, the elicitation of phytoalexins was inhibited.

It was reported in early work that dipping fruit in hot water at $52^{\circ} \mathrm{C}$ for 5 min combined with low doses of gamma radiation had a synergistic effect against the development of $P$. digitatum in vitro and in stored citrus fruit (Barkai-Golan et al., 1969). These integrated treatments delayed the appearance of green mould by about 40 days. A similar effect was observed when hot water dips and exposure to electron beam radiation were combined (Barkai-Golan and Padova, 1981). In contrast, no benefit from the combination of hot water with gamma radiation was observed for the reduction of green mould on grapefruit when compared to the effectiveness of each treatment alone (Spalding and Reeder, 1985).

\section{Combination of heat with low-toxicity chemical treatments}

Numerous studies have reported that heating aqueous solutions of GRAS compounds or chemical fungicides greatly improved their antifungal performance. Smilanick and co-workers (1997) tested several combinations of sodium carbonate (SC) concentrations and temperatures and found that 4 or $6 \% \mathrm{SC}$ applied at 40.6 or $43.3^{\circ} \mathrm{C}$ with were the most effective treatments to control green mould on oranges. Later, Palou and co-workers $(2001,2002 \mathrm{a})$ observed that immersion in 2-3\% SC or sodium bicarbonate (SBC) aqueous solutions at room temperature (around $20^{\circ} \mathrm{C}$ ) for $150 \mathrm{~s}$ reduced blue mould incidence by $50-70 \%$, and solutions at $45^{\circ} \mathrm{C}$ resulted in an additional $20-30 \%$ reduction without causing any rind damage on oranges and mandarins. On inoculated fruit treated and then stored at $3^{\circ} \mathrm{C}$, green and blue moulds were effectively controlled for the first 21 days of storage, but control, specially of blue mould, declined after more prolonged storage periods. Heated carbonate solutions were generally more effective on oranges (Palou et al., 2001) than on mandarins (Palou et al., 2002b; Venditti et al., 2005).

After testing several concentrations of about 40 different mineral or organic acid salts other than SC or SBC, Palou and co-workers (Palou et al., 2002a) found that immersion in $0.2 \mathrm{M}$ PS or SB aqueous solutions at $40^{\circ} \mathrm{C}$ and natural $\mathrm{pH}$ for $120 \mathrm{~s}$ reduced by $70 \%$ the incidence of green mould on artificially inoculated oranges. On lemons, disease reduction 
was higher than $80 \%$. Immersion in $1.0 \mathrm{mM}$ ammonium molybdate or $24.2 \mathrm{mM}$ sodium molybdate aqueous solutions at $48^{\circ} \mathrm{C}$ for $150 \mathrm{~s}$ effectively controlled both green and blue moulds on artificially inoculated oranges. At higher concentrations, these compounds were phytotoxic and stained the fruit peel (Palou et al., 2002a).

Control of sour rot (Kitagawa and Kawada, 1984) or green mould (Smoot and McCornack, 1978) was accomplished by immersion in heated PS solutions for about $2 \mathrm{~min}$, but some fruit were weakened and shorter treatments were advisable for potential commercial adoption. Treatments with aqueous solutions of $3 \%$ PS at $62^{\circ} \mathrm{C}$ for 30 or $60 \mathrm{~s}$ reduced penicillium moulds by up to $20,25,50,80$, or $95 \%$ on 1 -week incubated 'Clemenules' clementines, 'Nadorcott' mandarins, 'Fino' lemons, 'Ortanique' mandarins, and 'Valencia' oranges, respectively, clearly showing the important effect of the species and cultivar on the effectiveness of these treatments (Montesinos-Herrero et al., 2009a). In the control of green mould on inoculated fruit, PS was compatible with the fungicides IMZ, TBZ, PYR, and FLU and consistently improved their performance. Solutions of PS alone or combined with fungicides were more effective when they were applied at high temperature. Green mould caused by an isolate of $P$. digitatum resistant to IMZ and TBZ was effectively controlled when PS was added to heated solutions containing IMZ or TBZ at very low doses (Smilanick et al., 2008). Sour rot, which is not controlled by IMZ or TBZ (Schachnai and Barash, 1982) was reduced from $94.5 \%$ in control 'Eureka' lemons to 49.1 and $37.0 \%$ by 30 $\mathrm{s}$ immersion in PS at $1 \%$ at 25 and $50^{\circ} \mathrm{C}$, respectively (Smilanick et al., 2008). A brief double-dip rinse in tap water applied immediately after immersion of lemons in a $2 \%$ PS removed more than $90 \%$ of the PS residue without decreasing the treatment efficacy. Rinsing avoided the presence of apparent sediments on the fruit rind and protected it from excessive water loss (Montesinos-Herrero et al., 2009a). At equal effectiveness level, advantages of the use of PS compared with that of SC or SBC are related to the reduction of disposal issues, which include the high salinity, sodium content and $\mathrm{pH}$ of the carbonate solutions.

Combinations of non-restricted fungicides, gibberellic acid, GRAS compounds and elevated temperatures have been tested to limit sour rot and green mould infections, an important issue on export fruit from Australia. The most efficacious postharvest treatment was a combination 
of IMZ and SC either heated or not. Less effective but still satisfactory was the use of IMZ and mineral oil at ambient or higher temperatures, SC alone, or heated solutions of IMZ and carbendazim (Cunningham and Taverner, 2007). Solutions of sulphur dioxide or ethanol heated to $45^{\circ} \mathrm{C}$ controlled postharvest green mould on lemons at a level comparable to that achieved with SC and IMZ treatments (Smilanick et al., 1995). Heating aqueous solutions of low-toxicity alternative chemicals such as food additives or GRAS substances (e.g. SC, SBC, PS, SB, ethanol, sulphur dioxide, etc.), molybdate salts (Cunningham, 2010) or phosphite salts (Cerioni et al., 2013) significantly enhanced their effectiveness against penicillium molds. Accordingly, heating aqueous solutions of synthetic fungicides such as IMZ (Dore et al., 2009), TBZ (Schirra et al., 2008; D'Aquino et al., 2013a), FLU (Schirra et al., 2005), PYR (D'Aquino et al., 2006), SOPP (Barkai-Golan and Apelbaum, 1991), liquid lime-sulphur containing $0.75 \%$ calcium polysulfide (Smilanick and Sorenson, 2001) or cyprodinil (Schirra et al., 2009) increased the effectiveness and the persistence of the treatments. Heat probably facilitated the uptake of these compounds through the fruit cuticle (Schirra et al., 2000), allowing the use of lower doses of fungicides and thus, reducing costs and environmental risks. The most appropriate solution temperature should be specifically determined for each combination of active ingredient and fruit species and cultivar.

Curing of citrus following the application of low doses of synthetic fungicides effectively controlled citrus postharvest pathogens (Kinay et al., 2005; Zhang and Swingle, 2005). The combination of curing with GRAS compounds like SC (Lanza et al., 2004; Ahmed et al., 2007a,b;) or ethanol (Lanza et al., 2004) also improved the antifungal action of the individually applied treatments. Curing of mandarins followed by fumigations with 50 and $75 \mu \mathrm{L} / \mathrm{L}$ acetic acid for 15 min effectively controlled green mould on early and late harvested fruit, respectively. Furthermore, these combinations were not phytotoxic and some rind damage (pitting) was only observed on fruit treated with $100 \mu \mathrm{L} / \mathrm{L}$ acetic acid alone (Venditti et al., 2009). Venditti and co-workers observed that curing caused melting and remodelling of the epicuticular wax on the surface of the mandarin, allowing non-phytotoxic doses of acetic acid to exert its efficacy against the pathogen. 
As stated by Mulas and Schirra (2007), heat is unlikely to totally control fruit decay as a stand-alone method; however, it has an important role as a synergistic practice, together with the use of traditional or new fungicides, as well as a way to enhance the effect of GRAS products.

\section{Combination of low doses of ionising radiation with GRAS compounds or reduced levels of conventional fungicides}

Gamma radiation was applied in combination with diphenyl (BarkaiGolan and Kahan, 1967) or SOPP (Barkai-Golan and Apelbaum, 1991) to reduce penicillium moulds on citrus fruit. In both studies, the combination of the chemical fungicides with ionising radiation allowed to reduce both the radiation dose and the chemical concentration required to control the diseases. More recently, X-irradiation applied to clementine mandarins previously dipped in SC solutions significantly reduced the incidence and severity of green and blue moulds and prevented sporulation without injuring the fruit (Palou et al., 2007). Nevertheless, these beneficial effects were not high enough for commercial decay control standards and it was concluded that the combined treatments could not be a substitute for the use of conventional chemical fungicides.

\section{Combination of GRAS compounds with reduced levels of conventional fungicides}

The combinations of peracetic acid with FLU (Lanza et al., 2008) or hydrogen peroxide with calcium chloride $\left(\mathrm{CaCl}_{2}\right)$ or chitosan (El-Mougy et al., 2008) were synergistic and reduced green mould incidence more than each substance alone. The addition of SC or SBC treatments improved the performance of treatments with IMZ (Smilanick et al., 1999; Smilanick et al., 2005), TBZ (Smilanick et al., 2005; Lesar, 2008; Schirra et al., 2008) or PYR (Smilanick et al., 2006) against citrus postharvest pathogens. Likewise, PS presented a synergistic antifungal effect when combined with IMZ (Smilanick et al., 2008; MontesinosHerrero et al., 2009a), increased the efficacy against green mould of TBZ, PYR and FLU (Smilanick et al., 2008; D'Aquino et al., 2013a), and 
improved the performance of benzimidazoles against fungicide-resistant strains of $P$. digitatum (Nelson et al., 1981). One factor that may account for the considerable improvement of the efficacy of fungicides such as IMZ against green mould, even against fungicide-resistant strains, when applied together with SC, PS or other buffers that increase wound $\mathrm{pH}$, is an increase of either the pathogen membrane permeability or the mobility and toxicity of the fungicidal active ingredient when in its neutral molecular form (Smilanick et al., 2005, 2008; Montesinos-Herrero et al., 2009a). A standardised sequential treatment was recently tested to control citrus postharvest pathogens by combining oxidizing compounds widely used in food sanitation such as sodium hypochlorite $(\mathrm{NaClO})$ and hydrogen peroxide $\left(\mathrm{H}_{2} \mathrm{O}_{2}\right)$ with cupric sulphate $\left(\mathrm{CuSO}_{4}\right)$. The combined application of these compounds was synergistic and greatly reduced the dose of the oxidizing compounds normally required to exert their antimicrobial effect. Results from in vitro experiments showed a strong inhibition of the growth of $P$. digitatum, $G$. citri-aurantii and, to a lower extent $P$. italicum. On lemons, a significantly delay in fungal infection on treated fruit was observed (Cerioni et al., 2009).

\section{Edible coatings amended with low-toxicity chemicals}

For certain citrus fruit handling conditions and export markets, an important component of IDM programs may be the replacement of conventional postharvest waxes, often amended with high doses of synthetic fungicides, by natural edible coatings. Edible films and coatings have been used in the food industry to increase the shelf-life of many commodities, including fruits and vegetables. In fresh fruit, adequate edible coatings create a semi-permeable barrier to gas exchange and water vapour that reduces respiration rate and moisture loss and consequently delays fruit senescence (Navarro-Tarazaga et al., 2007; Olivas et al., 2008). Among other ingredients, edible coatings may incorporate non-polluting antimicrobials such as organic acids and theirs salts, parabens, chitosan, essential oils or other natural compounds to inhibit or delay the growth of contaminating microorganisms during storage or distribution of fresh or minimally processed horticultural products (Valencia-Chamorro et al., 2011). Chitosan has been used in recent studies as a carrier of additional antifungal compounds such as 
essential oils (Wang et al., 2011; Cháfer et al., 2012) or synthetic fungicides (El-Mougy et al., 2012) to enhance the activity against citrus green and blue molds. Recent in vitro studies have shown that, cornstarch edible films formulated with $0.5 \%$ Mexican oregano (Lippia berlandieri) essential oil inhibited the growth of Penicillium spp. (Avila-Sosa et al., 2009). In the case of citrus fruit, the antifungal activity of Mentha spicata and Lippia scaberrima essential oils as ingredients of citrus coatings was assessed in vitro, and in semicommercial and commercial trials (Combrinck et al., 2009; Du Plooy et al., 2009). A carnauba wax-based commercial coating amended with $L$. scaberrima, spray applied on 'Valencia' oranges before or after inoculation with $P$. digitatum, completely reduced green mould development after 6 days at $23^{\circ} \mathrm{C}$. Disease control and prevention were slightly higher than on oranges sprayed with commercial doses of TBZ or IMZ and guazatine. In addition, moisture loss significantly decreased in fruit treated with essential oil enriched coatings. The strong inhibitory activity of the terpenoid R-carvone against $P$. digitatum was found to be responsible for the effectiveness of the amended coatings (Du Plooy et al., 2009). In similar studies, Valencia-Chamorro and co-workers (2008) tested in vitro a wide variety of hydroxypropyl methylcellulose (HPMC)-lipid composite films containing food additives with antifungal properties against $P$. digitatum and $P$. italicum. They selected coatings containing either some organic acid salts or parabens and their mixtures to be tested in vivo on several commercially important citrus fruit cultivars. HPMClipid edible composite coatings containing PS, SB, SP, or some mixtures of these food additives were the most effective against green and blue moulds on artificially inoculated 'Clemenules' and 'Ortanique' mandarins, and 'Valencia' oranges treated and incubated at $20^{\circ} \mathrm{C}$ for 7 days (Valencia-Chamorro et al., 2009a). On 'Valencia' oranges and Clemenules' and 'Ortanique' mandarins stored at $5^{\circ} \mathrm{C}$ for long periods, edible coatings containing PS, SB, SP, or mixtures greatly reduced green and blue moulds, reduced weight loss and maintained fruit quality (Valencia-Chamorro et al., 2009b, 2010, 2011). Generally, edible coatings with GRAS ingredients were fungistatic rather than fungicidal and showed a curative, but not preventive, effect against green and blue moulds. The development of edible coatings with antifungal properties to control citrus postharvest diseases is a relatively new field of study and 
the promising results justify further research to develop new formulations or assess the compatibility of edible coatings with other strategies as part of IDM programs.

\section{Conclusions}

The development of postharvest diseases of fresh horticultural produce including citrus fruit requires the conjunction of three different factors: presence of infective pathogenic inoculum, susceptible fruit host, and adequate environmental conditions. The infection and decay process may be hindered by artificially manipulating any these three factors. The use of conventional synthetic fungicides is very effective to directly inactivate or kill the pathogen if the population of resistant strains in the packinghouse are kept under control. Moreover, these compounds provide long-term protection due to their typically high persistence. It is possible that alternative treatments that are neither polluting to the environment, nor toxic to humans or wildlife, nor injurious to fruit, might not show similar direct effects against the pathogens and reach similar levels of efficacy. Therefore, the implementation of alternative control methods increasingly requested by consumers and legislators requires the adoption of control strategies that devote much more attention to the other two vertexes of the disease triangle: host and environment. Accordingly, in the context of citrus IDM programs, good practices are required during the fruit growing season, harvest and postharvest life that contribute to improve the performance of postharvest alternative nonpolluting treatments and favour their efficacy. These practices include cultural actions in the field and appropriate sanitation of packinghouses to reduce the load of pathogenic inoculum, correct non-injurious harvest and adequate packingline procedures to avoid rind wounds and damage, and processing, storage and distribution of the fruit at proper handling and environmental conditions to preserve their natural defences.

Combinations of physical and low-toxicity chemical treatments have proved to be efficient in reducing the amounts of inoculum present on the surface of the fruit, controlling to some extent established infections and/or maintaining or inducing fruit resistance to fungal infections. Although the integration of treatments typically enhances the 
performance of stand-alone treatments, its efficacy and persistence still considerably depends on the fruit-pathogen interaction and consequently on different citrus species and cultivars and fruit physical and physiological condition. Studies to find new and more effective control methods and combination systems are still in progress. As advances in the knowledge about the mechanisms underlying host-pathogen interactions and the effect of the treatments on the physiology, biochemistry, and molecular biology of fruit are achieved, we will be closer to tailor the application of specific IDM strategies for each commodity and market circumstance.

\section{Acknowledgements}

The authors thank the Spanish 'Ministerio de Ciencia a Innovación' (MICINN) and the European Union FEDER program for funding some research in this topic (projects AGL-2004-05271 and RTA-2008-0007400-00). The IVIA is acknowledged for supporting the doctorate program of Clara Montesinos-Herrero.

\section{References}

Abd-El-Aziz SA and Mansour FS. Some safe treatments for controlling post-harvest diseases of Valencia orange (Citrus sinensis L.) fruits. Annals of Agricultural Science 2006: 44:135-146.

Ahmed DM, Hafez OM and Fouad AA. Sodium bicarbonate application as an alternative control of postharvest decay of blood orange fruits. Research Journal of Agriculture and Biological Sciences 2007a: 3:753-759.

Ahmed DM, Omaima MH and Solliman MED. Integrated control of postharvest decay on blood orange fruits by curing, hot water and sodium carbonate applications. Research Journal of Agriculture and Biological Sciences 2007b: 3:590-598.

Alférez F, Liao HL and Burn JK. Blue light alters infection by Penicillium digitatum in tangerines. Postharvest Biology and Technology 2012: 63:11-15. 
Ameziane N, Boubaker H, Msanda F, Jilal A and Benaoumar AA. Antifungal activity of Moroccan plants against citrus fruit pathogens. Agronomy for Sustainable Development 2007: 27:273-277.

Askarne L, Talibi I, Boubaker H, Boudyach EH, Msanda F, Saadi B and Ben Aoumar AA. Use of Moroccan medicinal plant extracts as botanical fungicide against citrus blue mould. Letters in Applied Microbiology 2013: 56:37-43.

Avila-Sosa R, Palou E and López-Malo A. Antifungal activity of starch edible films formulated with Mexican oregano (Lippia berlandieri Shauer) essential oil. In: Book of abstracts, IFT Annual Meeting and Food Expo. Anaheim, OC, CA, USA: Institute of Food Technologists; 2009: p. 157.

Bancroft MN, Gardner PD, Eckert JW and Baritelle JL. Comparison of decay control strategies in California lemon packinghouses. Plant Disease 1984: 68:24-28.

Barkai-Golan R and Apelbaum A. Synergistic effects of heat and sodium o-phenyl phenate treatments to inactivate Penicillium spores and suppress decay in citrus fruits. Tropical Science 1991: 31:229-233.

Barkai-Golan R and Kahan RS. Combined action of diphenyl and gamma radiation on the in vitro development of fungi pathogenic to citrus fruit. Phytopathology 1967: 7:696-698.

Barkai-Golan R and Padova R. Eradication of Penicillium on citrus fruits by electron radiation. Proceedings of the International Society of Citriculture 1981: 2:799-801.

Barkai-Golan R and Phillips DJ. Postharvest heat treatment of fresh fruits and vegetables for decay control. Plant Disease 1991: 75:1085-1089.

Barkai-Golan R, Kahan RS and Padova R. Synergistic effects of gamma radiation and heat on development of Penicillium digitatum in vitro and in stored citrus fruits. Phytopathology 1969: 59:922-924.

Barrera-Necha L, Bautista-Baños S, Bravo-Luna L, Bermúdez-Tores K, García-Suárez S, Jiménez-Estrada M and Reyes-Chilpa R. Antifungal activity against postharvest fungi by extracts and compounds of Pithecellobium dulce seeds (Huamuchil). Acta Horticulturae 2003: 628:761-766.

Ben-Arie R, Kvitnitsky E and Paluy I. Control of blue mold rot on mandarins with gaseous phase of essential oil. Acta Horticulturae 2011:905:275-281. 
Ben-Yehoshua S. Effects of postharvest heat and UV applications on decay, chilling injury and resistance against pathogens of citrus and other fruits and vegetables. Acta Horticulturae 2003: 599:159-173.

Ben-Yehoshua S, Barak E and Shapiro B. Postharvest curing at high temperatures reduces decay of individually sealed lemons, pomelos, and other citrus fruit. Journal of American Society of Horticultural Science 1987: 112:658-663.

Ben-Yehoshua $\mathrm{S}$ and Porat R. Heat treatments to reduce decay. In: Environmentally friendly technologies for agricultural produce quality. Ben-Yehoshua S (editor). Boca Raton, FL, USA: CRC Press, Taylor and Francis Group; 2005: pp. 265-299.

Ben-Yehoshua S and Rodov V. Developing a novel environmentally friendly microbiocidal formulation from peel of citrus fruit. Acta Horticulturae 2006: 712:275-284.

Ben-Yehoshua S, Rodov V, D'hallewin D and Dore A. Elicitation of resistance against pathogens in citrus fruits by combined UV illumination and heat treatments. Acta Horticulturae 2005: 682:20132020.

Ben-Yehoshua S, Rodov V, Kim JJ and Carmeli S. Preformed and induced antifungal materials of citrus fruits in relation to the enhancement of decay resistance by heat and ultraviolet treatments. Journal of Agricultural and Food Chemistry 1992: 40:1217-1221.

Bertolini P (editor). Proceedings of COST Action 924 International Congress, Novel approaches for the control of postharvest diseases and disorders. Bologna, Italy: CRIOF, University of Bologna; 2008.

Brown GE. Biology and control of Geotrichum candidum, the cause of citrus sour rot. Proceedings of the Florida State Horticultural Society 1979: 92:186-189.

Brown GE and Eckert JW. Green mold. In: Compendium of citrus diseases. Whiteside JO, Garnsey SM, Timmer LW (editors). St Paul, MN, USA: The American Phytopathological Society Press; 2000a: pp. 41-42.

Brown GE and Eckert JW. Sour rot. In: Compendium of citrus diseases. Whiteside JO, Garnsey SM, Timmer LW (editors). St Paul, MN, USA: The American Phytopathological Society Press; 2000b: p. 43. 
Brown GE, Ismail MA and Barmore CR. Lignification of injuries to citrus fruit and susceptibility to green mold. Proceedings of the Florida State Horticultural Society 1978: 91:124-126.

Caccioni DRL, Guizzardi M, Bionbi DM, Renda A and Ruberto G. Relationship between volatile components of citrus fruit essential oils and antimicrobial action on Penicillium digitatum and Penicillium italicum. International Journal of Food Microbiology 1998: 43:73-79.

Cerioni L, Rapisarda VA, Doctor J, Fikkert S, Ruiz T, Fassel R and Smilanick JL. Use of phosphite salts in laboratory and semicommercial tests to control citrus postharvest decay. Plant Disease 2013: 97: 201-212.

Cerioni L, Rapisarda VA, Hilal M, Prado FE and Rodríguez-Montelongo L. Synergistic antifungal activity of sodium hypochlorite, hydrogen peroxide, and cupric sulfate against Penicillium digitatum. Journal of Food Protection 2009: 72:1660-1665.

Cháfer M, Sánchez-González L, González-Martínez C and Chiralt A. Fungal decay and shelf life of oranges coated with chitosan and bergamot, thyme, and tea tree essential oils. Journal of Food Science 2012: 77: E182-E187.

Combrinck S, Regnier TJC and du Plooy W. Use of Lippia scaberrima essential oil in postharvest management of subtropical fruits. South African Journal of Botany 2009: 75:396.

Cunningham NM and Taverner PD. Efficacy of integrated postharvest treatments against mixed inoculations of Penicilium digitatum and Geotrichum citru-aurantii in 'Leng' navel oranges (Citrus sinensis). New Zealand Journal of Crop and Horticultural Science 2007: 35:187192.

Cunningham N. Combinations of treatments to replace the use of conventional fungicides for the commercial control of postharvest diseases of citrus fruit. Stewart Postharvest Review 2010: 1:1-8.

D'Aquino S, Fadda A, Barberis A, Palma A, Angioni A and Schirra M. 2013a. Combined effects of potassium sorbate, hot water and thiabendazole against green mould of citrus fruit and residue levels. Food Chemistry: 141:858-864.

D'Aquino S, Palma A, Angioni A and Schirra M. Residue levels and efficacy of fludioxonil and thiabendazole in controlling postharvest green mold decay in citrus fruit when applied in combination with 
sodium bicarbonate. Journal of Agricultural and Food Chemistry 2013b: 61:296-306.

D'Aquino S, Palma A, Mura D, Tedde M and Schirra M. The use of acetic acid to prevent decay in citrus fruit. In: Proceedings of COST Action 924 International Congress, Novel approaches for the control of postharvest diseases and disorders. Bertolini $\mathrm{P}$ (editor). Bologna, Italy: CRIOF, University of Bologna; 2008: pp. 396-402.

D'Aquino S, Schirra M, Palma A, Angioni A, Cabras P and Migheli Q. Residue levels and effectiveness of pyrimethanil vs imazalil when using heated postharvest dip treatments for control of Penicillium decay on citrus fruit. Journal of Agricultural and Food Chemistry 2006: 54:4721-4726.

Del Río JA and Ortuño A. Biosynthesis of flavonoids in citrus and its involvement in the antifungal defence mechanisms. In: Crop management and postharvest handling of horticultural products, Vol 4, Diseases and disorders of fruits and vegetables. Dris R, Niskanen R, Mohan Jain S (editors). Enfield, NH, USA: Science Publishers Inc.; 2004: pp. 185-220.

Dore A, Molinu MG, Venditti T and D'hallewin G. Immersion of lemons into imazalil mixtures heated at $50^{\circ} \mathrm{C}$ alters the cuticle and promotes permeation of imazalil into rind wounds. Journal of Agricultural and Food Chemistry 2009: 57:623-631.

Dore A, Molinu MG, Venditti T and D'hallewin G. Sodium bicarbonate induces crystalline wax generation, activates host-resistance, and increases imazalil level in rind wounds of oranges, improving the control of green mold during storage. Journal of Agricultural and Food Chemistry 2010: 58:7297-7304.

Droby S, Chalutz E, Horev B, Cohen L, Gaba V, Wilson CL and Wisniewski M. Factors affecting UV-induced resistance in grapefruit against the green mould decay caused by Penicillium digitatum. Plant Pathology 1993: 42:418-424.

Du Plooy W, Regnier $\mathrm{T}$ and Combrinck S. Essential oil amended coatings as alternatives to synthetic fungicides in citrus postharvest management. Postharvest Biology and Technology 2009: 53:117-122.

Dubery IA, Holzapfel CW, Kruger GJ, Schabort JC and Van Dyk M. Characterization of a gamma-radiation-induced antifungal stress metabolite in citrus peel. Phytochemistry 1988: 27:2769-2772. 
El-Mougy NS, El-Gamal NG and Abdalla MA. The use of fungicide alternatives for controlling postharvest decay of strawberry and orange fruits. Journal of Plant Protection Research 2008: 48:385-395.

El-Mougy NS, Abdel-Kader MM and Aly MH. Effect of a new chemical formula on postharvest decay incidence in citrus fruit. Journal of Plant Protection Research 2012: 52:156-264.

Erkan M, Pekmezci M and Wang CY. Hot water and curing treatments reduce chilling injury and maintain post-harvest quality of 'Valencia' oranges. International Journal of Food Science and Technology 2005: 40:91-96.

Fallik A. Prestorage hot water treatments (immersion, rinsing and brushing). Postharvest Biology and Technology 2004: 32:125-134.

FAO. Food and Agriculture Organization of the United Nations 2013:

FAO Statistical Yearbook 2013 [http://

www.fao.org/docrep/018/i3107e/i3107e03.pdf].

FAO. World markets for organic citrus and citrus juices: Current market situation and medium-term prospects 2003: [http://www.fao.org/docs/eims/upload/229991/organic_citrus_markets .pdf].

Fawcett HS. Packing house control of brown rot. Citograph 1922: 7:232234.

Hong S, Lee H and Kim D. Effects of hot water treatment on the storage stability of satsuma mandarin as a postharvest decay control. Postharvest Biology and Technology 2007: 43:271-279.

Kanetis L, Förster H and Adaskaveg JE. Comparative efficacy of the new postharvest fungicides azoxystrobin, fludioxonil, and pyrimethanil for managing citrus green mold. Plant Disease 2007: 91:1502-1511.

Karaca $\mathrm{H}$ and Sedat Velioglu Y. Ozone applications in fruit and vegetable processing. Food Reviews International 2007: 23:91-106.

Kim JJ, Ben-Yehoshua S, Shapiro B, Henis Y and Carmeli S. Accumulation of scoparone in heat-treated lemon fruit inoculated with Penicillium digitatum Sacc. Plant Physiology 1991: 97:880-885.

Kinay P, Mansour MF, Mlikota-Gabler F, Margosan DA and Smilanick JL. Characterization of fungicide-resistant isolates of Penicillium digitatum collected in California. Crop Protection 2007: 26:647-656. 
Kinay P, Yildiz F, Sen F, Yildiz M and Karacali I. Integration of pre- and postharvest treatments to minimize Penicillium decay of Satsuma mandarins. Postharvest Biology and Technology 2005: 37:31-36.

Kitagawa $\mathrm{H}$ and Kawada K. Effect of sorbic acid and potassium sorbate on the control of sour rot of citrus fruits. Proceedings of the Florida State Horticultural Society 1984: 97:133-135.

Kuniga T, Tsumura T, Matsuo $\mathrm{Y}$ and Matsumoto R. Changes in scoparone concentrations on citrus cultivars after ultraviolet radiation. Journal of the Japanese Society for Horticultural Science 2006: 75:328-330.

Ladaniya MS, Singh S and Wadhawan AK. Response of 'Nagpour' mandarin, 'Mosambi' sweet orange and 'Kagzi' acid lime to gamma radiation. Radiation Physics and Chemistry 2003: 67:665-675.

Lanza G, Aleppo EDM, Strano MC, Aloisi V and Privitera D. Effectiveness of peracetic acid in integrated control strategies of Penicillium decay in Tarocco orange fruit. In: Proceedings of COST Action 924 International Congress, Novel approaches for the control of postharvest diseases and disorders. Bertolini $\mathrm{P}$ (editor). Bologna, Italy: CRIOF, University of Bologna; 2008: pp. 60-65.

Lanza G, Di Martino Aleppo E and Strano MC. Evaluation of alternative treatments to control green mold in citrus fruit. Acta Horticulturae 2004: 632:343-349.

Lesar KH. The potential role of GRAS (generally regarded as safe) chemicals, alone and in combinations with the post-harvest fungicides, in the control of the major post-harvest citrus pathogens, Penicillium digitatum (citrus green mould) and Geotrichum candidum (sour rot). In: Proceedings of COST Action 924 International Congress, Novel approaches for the control of postharvest diseases and disorders. Bertolini P (editor). Bologna, Italy: CRIOF, University of Bologna; 2008: pp. 322-326.

Liao HL, Alférez F and Burns JK. Assessment of blue light treatments on citrus postharvest diseases. Postharvest Biology and Technology 2013: 81:81-88.

Ligorio A, Schena L, Albanese P, Pentimone I, Quinto G, Mennone C, Nigro F, Ippolito A and Salerno M. Pre- and postharvest application of salts for controlling green and blue mould of Clementine. In: Proceedings of COST Action 924 International Congress, Novel 
approaches for the control of postharvest diseases and disorders. Bertolini P (editor). Bologna, Italy: CRIOF, University of Bologna; 2008: pp. 387-395.

Linde JH, Combrinck S, Regnier TJC and Virijevic S. Chemical composition and antifungal activity of the essential oils of Lippia rehmannii from South Africa. South African Journal of Botany 2010: 76:37-42.

Liu X, Wang LP, Li YC, Li HY, Yu T and Zheng X-D. Antifungal activity of thyme oil against Geotrichum citri-aurantii in vitro and in vivo. Journal of Applied Microbiology 2009: 107:1450-1456.

Lurie S. Postharvest heat treatments. Postharvest Biology and Technology 1998: 14:257-269.

Mari M, Neri F and Bertolini P. Novel approaches to prevent and control postharvest diseases of fruits. Stewart Postharvest Review 2007: 6:5.

Mekbib SB, Regnier TJC and Korsten L. Control of Penicillium digitatum on citrus fruit using two plant extracts and study of their mode of action. Phytoparasitica 2007: 35:264-276.

Mekbib SB, Regnier TJC, Sivakumar D and Korsten L. Evaluation of Ethiopian plant extracts, Acacia seyal and Whitania somnifera, to control green and blue mould and ensure quality maintenance of citrus (Citrus sinensis L.). Fruits 2009: 64:285-294.

Montesinos-Herrero C, del Río MA, Pastor C, Brunetti O and Palou L. Evaluation of brief potassium sorbate dips to control postharvest penicillium decay on major citrus species and cultivars. Postharvest Biology and Technology 2009a: 52:117-125.

Montesinos-Herrero C, del Río MA, Rojas-Argudo C and Palou L. Short exposure to high $\mathrm{CO}_{2}$ and $\mathrm{O}_{2}$ at curing temperature to control postharvest diseases of citrus fruit. Plant Disease 2012: 96: 423-430.

Montesinos-Herrero C, del Río MA, Rojas-Argudo C and Palou L. Shortterm oxygen exposure at curing temperature to control postharvest penicillium molds on hybrid mandarins cv. Ortanique. Acta Horticulturae 2010: 876:365-371.

Montesinos-Herrero C, Smilanick JL, Hurley JM and Palou L. Potassium sorbate residue levels and persistence in citrus fruit as detected by a simple colorimetric method. Journal of Agricultural and Food Chemistry 2009b: 57:3458-3463. 
Moscoso-Ramírez PA, Montesinos-Herrero C and Palou L. Antifungal activity of sodium propylparaben alone or in combination with low doses of imazalil against Penicillium decay on citrus fruit. European Journal of Plant Pathology 2014:140: 145-157.

Moscoso-Ramírez PA, Montesinos-Herrero $\mathrm{C}$ and Palou L. Characterization of postharvest treatments with sodium methylparaben to control citrus green and blue molds. Postharvest Biology and Technology 2013a: 77: 128-137.

Moscoso-Ramírez PA, Montesinos-Herrero C and Palou L. Control of citrus postharvest penicillium molds with sodium ethylparaben. Crop Protection 2013b: 46: 44-51.

Moscoso-Ramírez PA and Palou L. 2014. Preventive and curative activity of postharvest potassium silicate treatments to control green and blue molds on orange fruit. European Journal of Plant Pathology 2014: 138:721-732.

Mulas M and Schirra M. The effect of heat conditioning treatments on the postharvest quality of horticultural crops. Stewart Postharvest Review 2007: 3:1.

Muñoz A, López-García B and Marcos JF. Comparative study of antimicrobial peptides to control citrus postharvest decay caused by Penicillium digitatum. Journal of Agricultural and Food Chemistry 2007: 55:8170-8176.

Muñoz A and Marcos JF. Activity and mode of action against fungal phytopathogens of bovine lactoferricin-derived peptides. Journal of Applied Microbiology 2006: 101:1199-1207.

Naqvi SAMH. Diagnosis and management of pre and post-harvest diseases of citrus fruit. In: Diseases of fruits and vegetables. Diseases and management. Naqvi SAMH (editor). Dordrecht, The Netherlands: Kluwer Academic Publishers; 2004: pp. 339-359.

Narayanasamy P. Postharvest pathogens and disease management. Hoboken, NJ, USA: John Wiley \& Sons Inc., Wiley-Interscience; 2006.

Navarro-Tarazaga ML, Pérez-Gago MB, Gonder K and Plotto A. A new composite coating containing HPMC, beeswax, and shellac for 'Valencia' oranges and 'Marisol' tangerines. Proceedings of the Florida State Horticultural Society 2007: 120:1-7. 
Nelson PM, Wheeler RW and McDonald PD. Potassium sorbate in combination with benzimidazoles reduces resistant Penicillium digitatum decay in citrus. Proceedings of the International Society of Citriculture 1981: 2:820-823.

Nunes C, Usall J, Manso T, Torres R, Olmo M and García JM. Effect of high temperature treatments on growth of Penicillium spp. and development on 'Valencia' oranges. Food Science and Technology International 2007: 13:63-68.

Obagwu $\mathrm{J}$ and Korsten L. Control of citrus green and blue molds with garlic extracts. European Journal of Plant Pathology 2003: 109:221225.

Olivas GI, Dávila-Aviña JE, Salas-Salazar NA and Molina FJ. Use of edible coatings to preserve the quality of fruits and vegetables during storage. Stewart Postharvest Review 2008: 3:6.

Palou L. Control of citrus postharvest diseases by physical means. Tree and Forestry Science and Biotechnology 2009: 3:127-142.

Palou L. Penicillium digitatum, Penicillium italicum (Green mold, Blue mold). In: Postharvest Decay. Control Strategies. Bautista-Baños, S. (editor). London, UK: Academic Press, Elsevier Inc.; 2014: pp. 45102.

Palou L, Marcilla A, Rojas-Argudo C, Alonso M, Jacas JA and del Río MA. Effects of X-ray irradiation and sodium carbonate treatments on postharvest Penicillium decay and quality attributes of clementine mandarins. Postharvest Biology and Technology 2007: 46:252-261.

Palou L, Montesinos-Herrero $\mathrm{C}$ and del Río MA. Short-term $\mathrm{CO}_{2}$ exposure at curing temperature to control postharvest green mold of mandarins. Acta Horticulturae 2008: 768: 257-263.

Palou L, Smilanick JL and Droby S. Alternatives to conventional fungicides for the control of citrus postharvest green and blue moulds. Stewart Postharvest Review 2008: 2:2.

Palou L, Smilanick JL and Margosan DA. Ozone application for sanitation and control of postharvest diseases of fresh fruits and vegetables. In: Recent advances in alternative postharvest technologies to control fungal diseases in fruits \& vegetables. Troncoso-Rojas R, Tiznado-Hernández ME, González-León A (editors). Trivandrum, Kerala, India: Transworld Research Network; 2007: pp. 39-70. 
Palou L, Smilanick JL, Montesinos-Herrero C, Valencia-Chamorro S and Pérez-Gago MB. Novel approaches for postharvest preservation of fresh citrus fruits. In: Citrus fruits: properties, consumption and nutrition. Slaker DA (editor). New York, USA: Nova Science Publishers, Inc.; 2011: pp. 1-45.

Palou L, Smilanick JL, Usall J and Viñas I. Control of postharvest blue and green molds of oranges by hot water, sodium carbonate, and sodium bicarbonate. Plant Disease 2001: 85:371-376.

Palou L, Usall J, Muñoz JA, Smilanick JL and Viñas I. Hot water, sodium carbonate, and sodium bicarbonate for the control of postharvest green and blue molds of clementine mandarins. Postharvest Biology and Technology 2002b: 24:93-96.

Palou L, Usall J, Smilanick JL, Aguilar MJ and Viñas I. Evaluation of food additives and low-toxicity compounds as alternative chemicals for the control of Penicillium digitatum and Penicillium italicum on citrus fruit. Pest Management Science 2002a: 58:459-466.

Plaza P, Sanbruno A, Usall J, Lamarca N, Torres R, Pons J and Viñas I. Integration of curing treatments with degreening to control the main postharvest diseases of clementine mandarins. Postharvest Biology and Technology 2004: 34:29-37.

Plaza P, Torres R, Usall J, Lamarca N and Viñas I. Evaluation of the potential of commercial post-harvest application of essential oils to control citrus decay. Journal of Horticultural Science \& Biotechnology 2004: 79:935-940.

Porat R, Daus A, Weiss B, Cohen L, Fallik E and Droby S. Reduction of postharvest decay in organic citrus fruit by a short hot water brushing treatment. Postharvest Biology and Technology 2000a: 18:151-157.

Porat R, Pavoncello D, Peretz J, Weiss D, Daus A, Cohen E, BenYehoshua S, Fallik A, Droby S and Lurie S. Induction of resistance to Penicillium digitatum and chilling injury in 'Star Ruby' grapefruit by a short hot-water rinse and brushing treatment. Journal of Horticultural Science \& Biotechnology 2000b: 75:428-432.

Riov J. 6,7-dimethoxycoumarin in the peel of gamma-irradiated grapefruit. Phytochemistry 1971: 10:1923.

Rodov V, Agar T, Peretz J, Nafussi B, Kim JJ and Ben-Yehoshua S. Effect of combined application of heat treatments and plastic packaging on keeping quality of 'Oroblanco' fruit (Citrus grandis L. $\mathrm{x}$ 
C. paradisi Macf.). Postharvest Biology and Technology 2000: 20:287-294.

Rodov V, Ben-Yehoshua S, Fang DQ, Kim JJ and Ashkenazi R. Preformed antifungal compounds of lemon fruit: citral and its relation to disease resistance. Journal of Agricultural and Food Chemistry 1995: 43:1057-1061.

Saks Y and Barkai-Golan R. Aloe vera gel activity against plant pathogenic fungi. Postharvest Biology and Technology 1995: 6:159_ 165.

Salamone A, Scarito G, Pirajimo G, Barone F and Calabrese F. Lemon post-harvest decay control by natural products. In: Book of abstracts, 11th International Citrus Congress. Wuhan, China: International Society of Citriculture 2008: p. 33.

Schachnai A and Barash I. Evaluation of the fungicides CGA 64251, guazatine, sodium $o$-phenylphenate, and imazalil for control of sour rot on lemon fruits. Plant Disease 1982: 66:733-735.

Schirra M, Angioni A, Ruggiu R, Minelli EV and Cabras P. Thiabendazole uptake and persistence in lemons following postharvest dips at $50^{\circ} \mathrm{C}$. Italian Journal of Food and Science 1998: 10:165-170.

Schirra M, D'Aquino S, Cabras P and Angioni A. Influence of postharvest application rates of cyprodinil, treatment time and temperature on residue levels and efficacy in controlling green mould on 'Valencia' oranges. Food Additives and Contaminants 2009: 26:10331037.

Schirra M, D'Aquino S, Palma A, Angioni A and Cabras P. Factors affecting the synergy of thiabendazole, sodium bicarbonate, and heat to control postharvest green mold of citrus fruit. Journal of Agricultural and Food Chemistry 2008: 56:10793-10798.

Schirra M, D'Aquino S, Palma A, Angioni A, Cabras P and Migheli Q. Residues of the quinone outside inhibitor fungicide trifloxystrobin after postharvest dip treatments to control Penicillium spp. on citrus fruit. Journal of Food Protection 2006: 69:1646-1652.

Schirra M, D'Aquino S, Palma A, Marceddu S, Angioni A, Cabras P, Scherm B and Migueli Q. Residue level, persistence, and storage performance of citrus fruit treated with fludioxonil. Journal of Agricultural and Food Chemistry 2005: 53:6718-6724. 
Schirra M, D'hallewin G, Ben-Yehoshua S and Fallik E. Host-pathogen interactions modulated by heat treatment. Postharvest Biology and Technology 2000: 21:71-85.

Shikanga E, Regnier TJC, Combrinck S and Botha B. Polar Lippia extracts as alternatives for the postharvest control of Guazatine ${ }^{\circledR}$ resistant strains of Penicillium digitatum in citrus. Fruits 2009: 64:7582.

Smilanick JL, Brown GE and Eckert JW. The biology and control of postharvest diseases. In: Fresh citrus fruits, $2^{\text {nd }}$ edition. Wardowski WF, Miller WM, Hall DJ, Grierson W (editors). Longboat Key, FL, USA: Florida Science Source Inc.; 2006: pp. 339-396.

Smilanick JL, Mackey BE, Reese R, Usall J and Margosan DA. Influence of concentration of soda ash, temperature, and immersion period on the control of postharvest green mold on oranges. Plant Disease 1997: 81:379-382.

Smilanick JL, Mansour MF, Margosan DA, Mlikota-Gabler F and Goodwine WR. Influence of $\mathrm{pH}$ and $\mathrm{NaHCO}_{3}$ on effectiveness of imazalil to inhibit germination of Penicillium digitatum and to control postharvest green mold on citrus fruit. Plant Disease 2005: 89:640648.

Smilanick JL, Mansour MF, Mlikota-Gabler F and Goodwine WR. The effectiveness of pyrimethanil to inhibit germination of Penicillium digitatum and to control citrus green mold after harvest. Postharvest Biology and Technology 2006: 42:75-85.

Smilanick JL, Mansour MF, Mlikota-Gabler F and Sorenson D. Control of citrus postharvest green mold and sour rot by potassium sorbate combined with heat and fungicides. Postharvest Biology and Technology 2008: 47:226-238.

Smilanick JL, Margosan DA and Henson DJ. Evaluation of heated solutions of sulfur dioxide, ethanol, and hydrogen peroxide to control postharvest green mold of lemons. Plant Disease 1995: 79:742-747.

Smilanick JL, Margosan DA, Mlikota-Gabler F, Usall J and Michael IF. Control of citrus green mold by carbonate and bicarbonate salts and the influence of commercial postharvest practices on their efficacy. Plant Disease 1999: 83:139-145. 
Smilanick JL and Sorenson D. Control of postharvest decay of citrus fruit with calcium polysulfide. Postharvest Biology and Technology 2001: 21:157-168.

Smilanick JL, Sorenson D, Mansour MF, Aieyabei J and Plaza P. Impact of a brief postharvest hot water drench treatment on decay, fruit appearance, and microbe populations of California lemons and oranges. HortTechnology 2003: 13:333-338.

Smoot JJ and McCornack AA. The use of potassium sorbate for citrus decay control. Proceedings of the Florida State Horticultural Society 1978: 91:119-122.

Spalding DH and Reeder WF. Effect of hot water and gamma radiation on postharvest decay of grapefruit. Proceedings of the Florida State Horticultural Society 1985: 98:207-208.

Szczerbanik M, Jobling J, Morris S and Holford P. Essential oil vapours control some common postharvest fungal pathogens. Australian Journal of Experimental Agriculture 2007: 47:103-109.

Tavallali V, Karimi S, Mohammadi S and Hojati S. Effects of baminobutyric acid on the induction of resistance to Penicillium italicum. World Applied Sciences Journal 2008: 5:345-351.

Tayel AA, El-Baz AF, Salem MF and El-Hadary MH. Potential applications of pomegranate peel extract for the control of citrus green mould. Journal of Plant Disease Protection 2009: 116:252-256.

Tripathi P, Dubey NK, Banerji R and Chansouria JPN. Evaluation of some essential oils as botanical fungitoxicants in management of postharvest rotting of citrus fruits. World Journal of Microbiology \& Biotechnology 2004: 20:317-321.

Troncoso-Rojas R, Tiznado-Hernández ME and González-León A (editors). Recent advances in alternative postharvest technologies to control fungal diseases in fruits \& vegetables. Trivandrum, Kerala, India: Transworld Research Network; 2007.

Valencia-Chamorro SA, Palou L, del Río MA, Pérez-Gago MB. Antimicrobial edible films and coatings for fresh and minimally processed fruits and vegetables: a review. Critical Reviews in Food Science and Nutrition 2011:51: 872-900.

Valencia-Chamorro SA, Palou L, del Río MA and Pérez-Gago MB. Inhibition of Penicillium digitatum and Penicillium italicum by hydroxypropyl methylcellulose-lipid edible films containing food 
additives with antifungal properties. Journal of Agricultural and Food Chemistry 2008: 56:11270-11278.

Valencia-Chamorro S, Palou L, del Río MA and Pérez-Gago MB. Performance of hydroxypropyl methylcellulose (HPMC)-lipid edible composite coatings containing food additives with antifungal properties during cold storage of 'Clemenules' mandarins. LWT Food Science and Technology 2011: 44:2342-2348.

Valencia-Chamorro SA, Pérez-Gago MB, del Río MA and Palou L. Curative and preventive activity of hydroxypropyl methylcelluloselipid edible composite coatings containing antifungal food additives to control citrus postharvest green and blue moulds. Journal of Agricultural and Food Chemistry 2009a: 57: 2770-2777.

Valencia-Chamorro SA, Pérez-Gago MB, del Río MA and Palou L. Effect of antifungal hydroxypropyl methylcellulose-lipid edible composite coatings on Penicillium decay development and postharvest quality of cold-stored 'Ortanique' mandarins. Journal of Food Science 2010: 75:S418-S426.

Valencia-Chamorro SA, Pérez-Gago MB, del Río MA and Palou L. Effect of antifungal hydroxypropyl methylcellulose (HPMC)-lipid edible composite coatings on postharvest decay development and quality of cold-stored 'Valencia' oranges. Postharvest Biology and Technology 2009b: 54:72-79.

Venditti T, Dore A, Molinu MG, Agabbio M and D'hallewin G. Combined effect of curing followed by acetic acid vapour treatments improves postharvest control of Penicillium digitatum on mandarins. Postharvest Biology and Technology 2009: 54:111-114.

Venditti T, Molinu MG, Dore A, Agabbio M and D'hallewin G. Sodium carbonate treatment induces scoparone accumulation, structural changes, and alcalinization in the albedo of wounded Citrus fruits. Journal of Agricultural and Food Chemistry 2005: 53:3510-3518.

Wang CY. Chilling injury in horticultural communities. HortScience 1994: 29:986-988.

Wang LN, Liu F, Jiang YF, Chai Z, Li PL, Cheng YQ, Jing H, Leng XJ. Synergistic antimicrobial activities of natural essential oils with chitosan films. Journal of Agricultural and Food Chemistry 2011:59: 12411-12419. 
Wang S, Tang $\mathbf{J}$ and Cavalieri RP. Modelling fruit internal heating rates for hot air and hot water treatments. Postharvest Biology and Technology 2001: 22:257-270.

Wu T, Zivanovic S, Draughon FA, Conway WS and Sams CE. Physicochemical properties and bioactivity of fungal chitin and chitosan. Journal of Agricultural and Food Chemistry 2005: 53:38883894.

Yahyazadeh M, Omidbaigi R, Zare R and Taheri H. Effect of some essential oils on mycelial growth of Penicillium digitatum Sacc. World Journal of Microbiology \& Biotechnology 2008: 24:14451450.

Zapata PJ, Navarro D, Guillén F, Castillo S, Martínez-Romero D, Valero D and Serrano M. Characterisation of gels from different Aloe spp. as antifungal treatment: Potential crops for industrial applications. Industrial Crops and Products 2013: 42:223-230.

Zhang $\mathbf{J}$ and Swingle PP. Effects of curing on green mold and stem -end rot of citrus fruit and its potential application under Florida packing system. Plant Disease 2005: 89:834-840. 

GENERAL OBJECTIVES 



\section{OBJECTIVES}

General objective of the thesis is to evaluate alternatives to synthetic fungicides to be used alone or in combination for non-polluting control of citrus postharvest green and blue molds, caused by the pathogens Penicillium digitatum and $P$. italicum, respectively.

\section{Specific objectives}

1. To test the efficacy of postharvest treatments with aqueous solutions of several food additives against green and blue molds of citrus fruit, and to assess the feasibility of the application of selected compounds, viz. sodium benzoate (SB), as part of the commercial handling procedures followed in the citrus packinghouses for decay control.

2. To assess the effectiveness of brief postharvest dip treatments with aqueous solutions of potassium sorbate (PS) against postharvest penicillium molds of citrus fruit and determine the best application conditions (concentration, temperature, immersion time). To evaluate the performance of PS treatments on long-term cold-stored fruit, commercially important citrus species and cultivars, and in combination with low doses of the fungicide imazalil (IMZ).

3. To develop a simple colorimetric method for the determination of PS residues in citrus fruit based on the reaction with thiobarbituric acid. To apply this method to evaluate the influence of PS concentration on residue levels, determine the effectiveness of water rinse and high pressure water wash to remove PS residues, and assess the evolution of PS residue levels in treated fruit during storage.

4. To evaluate short exposure of several citrus fruit cultivars to high $\mathrm{CO}_{2}$ or $\mathrm{O}_{2}$ controlled atmospheres at curing temperature as a method to either control established infections of $P$. digitatum and $P$. italicum or induce physical and/or biochemical changes in the fruit that could maintain or increase their resistance to infection. 
5. To determine the potential synergy of the combination of postharvest dip treatments with PS and brief exposures to high $\mathrm{CO}_{2}$ or $\mathrm{O}_{2}$ atmospheres at curing temperature for green mold control. Comparison with individual treatments.

6. To assess both in vitro and in vivo the effectiveness of brief ammonia fumigations to control citrus green and blue molds and determine their influence on fruit quality, especially on rind color of lemon fruit. To explore the interaction of ammonia fumigation with IMZ treatments.

7. To investigate the relative susceptibility of commercially important citrus species and cultivars to green and blue molds, and evaluate the relationship between this susceptibility and fruit quality attributes. 
Chapter 1

\title{
Evaluation of sodium benzoate and other food additives for the control of citrus postharvest green and blue molds
}

\author{
CLARA MONTESINOS-HERRERO ${ }^{1}$, PEDRO A. MOSCOSO- \\ RAMÍREZ $^{1,2}$ and LLUÍS PALOU ${ }^{1}$ \\ ${ }^{1}$ Laboratori de Patologia, Centre de Tecnologia Postcollita (CTP) \\ Institut Valencià d'Investigacions Agràries (IVIA) \\ Apartat Oficial, 46113 Montcada, València, Spain \\ ${ }^{2}$ Campus Tabasco, Colegio de Postgraduados \\ 86500 H. Cárdenas, Tabasco, México
}

Reference: Postharvest Biology and Technology 2016, 115, 72-80. 



\begin{abstract}
The curative activity of the food additives dehydroacetic acid, dimethyl dicarbonate, ethylene diamine tetracetic acid, sodium acetate, and sodium benzoate (SB) was tested in in vivo preliminary screenings against green and blue molds on citrus fruit artificially inoculated $24 \mathrm{~h}$ before with Penicillium digitatum and $P$. italicum, respectively. SB was the most effective compound and it was further tested in trials simulating postharvest industrial applications. Dip treatments for $60 \mathrm{~s}$ with 3\% (w/v) SB heated above $50{ }^{\circ} \mathrm{C}$ resulted in about $90 \%$ reduction of green and blue mold incidence on 'Valencia' oranges inoculated, treated, and incubated at $20^{\circ} \mathrm{C}$ and $90 \% \mathrm{RH}$ for 7 days. This treatment was also effective on 'Lanelate' oranges, 'Fino' lemons and 'Ortanique' mandarins, but not on 'Clemenules' mandarins. Heated solutions combining SB with low doses ( 25 or $50 \mu \mathrm{L} \mathrm{L}^{-1}$ ) of the fungicide imazalil (IMZ) were synergistic and greatly improved the efficacy of stand-alone treatments. On 'Valencia' oranges stored for 8 weeks at $5{ }^{\circ} \mathrm{C}$ followed by 7 days of shelf-life at 20 ${ }^{\circ} \mathrm{C}$, this combination reduced the incidence of green and blue molds almost by $100 \%$. It was found in additional trials to test the preventive activity that $3 \% \mathrm{SB}$ dips at $50^{\circ} \mathrm{C}$ for $60 \mathrm{~s}$ did not reduce green mold on 'Valencia' oranges treated, inoculated with $P$. digitatum 24 h later, and incubated at $20{ }^{\circ} \mathrm{C}$ for 7 days. It can be concluded from this work that heated SB aqueous solutions might be in the future an interesting nonpolluting disease control alternative for the commercialization of citrus in markets with zero tolerance to fungicide residues.
\end{abstract}

\title{
1. Introduction
}

The most common citrus postharvest diseases in Mediterranean climate regions are green and blue molds, caused by Penicillium digitatum and P. italicum, respectively (Eckert and Eaks, 1989; Palou, 2014). Economic losses due to these diseases have been reduced to commercially acceptable levels by the use of synthetic fungicides such as imazalil (IMZ), thiabendazole (TBZ), sodium-o-phenylphenate, or others for more than 30 years (Brown, 1985; Erasmus et al., 2013; D'Aquino et al., 2013). Deeper knowledge about residue levels in fruit and the toxicology of these fungicides and, on the other hand, consumers trends to eat more natural food, are favoring a continuous reduction in the amount of these substances allowed by authorities to be present on fruit. 
Furthermore, at present, large citrus distributors and major supermarket chains are even demanding particular and more restrictive fungicide usage. In addition, rising populations of resistant strains of diseasecausing pathogens to these fungicides are an important thread, which is compromising the efficacy of the treatments (Bus et al., 1991; Eckert et al., 1994; Holmes and Eckert, 1995; Zhu et al., 2006; Kinay et al., 2007; Sánchez-Torres and Tuset, 2011). Consequently, the citrus industry worldwide is increasing demanding for alternatives to conventional fungicides to control postharvest diseases. In the last few years, many studies have been published and reviewed on alternatives to synthetic fungicides for the control of postharvest decay of fresh horticultural produce (Palou et al., 2008; Cunningham, 2010; Janisiewicz and Conway, 2010; Montesinos-Herrero and Palou, 2010; Romanazzi et al., 2012; Bautista-Baños, 2014). Among them, dip treatments with low toxicity substances with antimicrobial properties has been one of the first approaches (Hall, 1988), since the substitution of synthetic fungicides by these products would not require substantial changes in the industrial procedures followed in the packinghouses. These alternative compounds should be natural or synthetic substances with toxicity to humans and wildlife extensively evaluated and proven to be very low. Food additives, especially preservatives, and generally regarded as safe (GRAS) compounds, which are allowed with very few restrictions for many industrial and agricultural applications by regulations worldwide meet these conditions. A number of food additives have been successfully tested for this purpose against citrus postharvest diseases. These include carbonates and bicarbonates (Smilanick et al., 1999; Sorenson et al., 1999; Palou et al., 2001, 2002; Zhang and Swingle, 2003; Plaza et al., 2004; Venditti et al., 2005; Youssef et al., 2014), potassium sorbate (Smilanick et al., 2008; Montesinos-Herrero et al., 2009), or sodium parabens (Moscoso-Ramírez et al., 2013a,b, 2014). Other food additives with antimicrobial activity, commonly used as preservatives, may have similar control ability when applied as postharvest treatments against citrus pathogens, but they have not been extensively assayed in postharvest applications. This is the case of sodium benzoate (SB; EU food additive number E-211), which was first identified as a potential citrus postharvest antifungal agent by Hall (1988). This worker found that the efficacy of treatments with $2 \%(\mathrm{w} / \mathrm{v}) \mathrm{SB}$ in the control of green 
mold was similar to that of TBZ commercial treatments. More recently, Palou et al. (2009) tested in vivo several food additives against postharvest pathogens of stone fruit such as Monilinia fructicola, Botrytis cinerea, Geotrichum candidum, Alternaria alternata, or Penicillium expansum and found that treatments with $200 \mathrm{mM} \mathrm{SB}$ were among the most effective in the control of diseases caused by these pathogens. In vitro assays with ethylendiaminetetraacetic acid (EDTA, E-385) showed complete inhibition of $P$. italicum growth and sporulation (Askarne et al., 2011). Dehydroacetic acid sodium salt (NaDHA, E-265) was successfully tested in dip treatments to reduce postharvest spoilage of different fruit and vegetables (Smith, 1962). In preliminary tests, sodium acetate salts (NaAc, E-262) reduced by $70 \%$ the incidence of gray mold caused B. cinerea on sweet cherries compared to the water control treatment (Ippolito et al., 2005). Postharvest treatments with $200 \mathrm{mg} \mathrm{L}^{-1}$ of dimethyl dicarbonate (DMDC, E-242) significantly reduced the total mold count of the leaf and stalk of Chinesse cabbage and this substance was suggested as an alternative sanitation treatment (Chen et al., 2013). Likewise, count of total yeasts and molds in fresh-cut carrots treated with DMDC were significantly reduced by 3.01 and $3.43 \log \mathrm{cfu} \mathrm{g}^{-1}$, respectively, in comparison with water-treated controls (Wang et al., 2012). Therefore, according to such previous reports, the objective of the present work was to test the efficacy of postharvest treatments with SB, EDTA, NaDHA, NaAc, and DMDC against green and blue molds of citrus fruit, and to assess the feasibility of the application of selected compounds, viz. SB, as part of the commercial handling procedures followed in the packinghouses for decay control.

2. Materials and methods

2.1. Fruit

Fruit used in the experiments were 'Valencia' and 'Lanelate' oranges (Citrus sinensis (L.) Osbeck), 'Clemenules' (synonyms: 'Nules', 'Clementina de Nules') clementine mandarins (Citrus clementina Hort. ex Tanaka), 'Ortanique' [Citrus reticulata Blanco x (C. sinensis x $C$. reticulata); synonym: 'Topaz'] hybrid mandarins, and 'Fino' lemons (Citrus limon (L.) Burm.). Fruit were collected from commercial orchards in the Valencia area (Spain) and used the same day or stored up to 1 week at $5{ }^{\circ} \mathrm{C}$ and $90 \%$ relative humidity (RH) before use. Fruit used 
in the study were free from previous postharvest treatments or coatings. Before each experiment, fruit were selected, randomized, washed with tap water and allowed to air-dry at room temperature.

\subsection{Fungal inoculation}

Penicillium digitatum and $P$. italicum, isolates NAV-7 and MAV1 , respectively, from the fungal culture collection of the IVIA CTP, were cultured on potato dextrose agar (PDA, Sigma-Aldrich Chemical Co., St. Louis, MA, USA) plates at $25^{\circ} \mathrm{C}$. Conidia of each fungus from 7 to 14day-old cultures were taken from the agar surface with a sterile rod and transferred to a sterile aqueous solution of $0.05 \%$ Tween ${ }^{\circledR} 80$ (Panreac, S.A.U., Barcelona, Spain). Conidial suspensions were filtered through two layers of cheesecloth to separate hyphal fragments and adjusted to a concentration of $10^{5}$ or $10^{6}$ spores $\mathrm{mL}^{-1}$ using a haemocytometer. The tip of a stainless steel rod, $1 \mathrm{~mm}$ wide and $2 \mathrm{~mm}$ in length, was immersed in the conidial suspension and inserted in the fruit rind afterwards. Except for in vivo primary screening tests, fruit were inoculated at two opposite points in the fruit equatorial zone, one with $P$. digitatum and the other with $P$. italicum. Inoculated fruit were kept in a temperature-controlled room at $20{ }^{\circ} \mathrm{C}$ and $90 \% \mathrm{RH}$ for $24 \mathrm{~h}$, until treatment. In the case of in vivo primary screenings, each pathogen was inoculated in different sets of fruit.

\subsection{In vivo primary screenings}

Several substances, previously selected for their potential antifungal properties, were tested at different concentrations to assess their control ability of citrus postharvest green and blue molds on fruit previously inoculated with the pathogens. These concentrations and substances were 100 and $200 \mathrm{mM} \mathrm{SB}\left(\mathrm{NaC}_{7} \mathrm{H}_{5} \mathrm{NaO}_{2}\right.$; Guinama S.L., Alboraia, València, Spain); 0.1, 1, 10, 20, 40, 50, 70, and $100 \mathrm{mM}$ EDTA $\left(\mathrm{C}_{10} \mathrm{H}_{16} \mathrm{~N}_{2} \mathrm{O}_{8}\right) ; 0.1,1,4,7,10,20,30,40,70$, and $100 \mathrm{mM} \mathrm{NaDHA}$ $\left(\mathrm{C}_{8} \mathrm{H}_{8} \mathrm{O}_{4}\right) ; 1,10,40,70,100,140,170,200,300,400,500,600,800$, and $1000 \mathrm{mM} \mathrm{NaAc}\left(\mathrm{NaC}_{2} \mathrm{H}_{3} \mathrm{O}_{2}\right)$; and $0.07,0.75,7.5,75,150,300,450$, and $600 \mathrm{mM}$ DMDC $\left(\mathrm{C}_{4} \mathrm{H}_{6} \mathrm{O}_{5}\right)$ (all purchased to Sigma-Aldrich Chemie Gmbh, Steinheim, Germany). Inoculation with $P$. digitatum or $P$. italicum was carried out following the procedure described above, with an inoculum concentration of $10^{5}$ spores $\mathrm{mL}^{-1}$. About $24 \mathrm{~h}$ after fungal 
inoculation, $30 \mu \mathrm{L}$ of the solution to be tested at the specified concentration were placed, using a micropipette, in the same inoculation rind wound. Control fruit were treated with $30 \mu \mathrm{L}$ of sterile distilled water. For each combination of pathogen, substance, and concentration, 4 replicates of 5 'Valencia' oranges each were used. Treated fruit were incubated at $20^{\circ} \mathrm{C}$ and $90 \% \mathrm{RH}$ for 3 and 6 days, at which time disease incidence ( $\%$ of infected fruit) was determined. Trials were repeated three times, and average values were calculated.

\subsection{Dip treatment conditions}

Since SB at $200 \mathrm{mM}\left(29 \mathrm{~g} \mathrm{~L}^{-1} ; 2.9 \% \mathrm{w} / \mathrm{v}\right)$ was selected as the best among all treatments assayed in the previous in vivo primary screening tests, trials with 3\% SB were conducted using 'Valencia' oranges to establish the best dip conditions for this treatment. Fruit were inoculated with $P$. digitatum and $P$. italicum at a concentration of $10^{6}$ spores $\mathrm{mL}^{-1}$ following the procedure mentioned above, and then dip-treated using stainless steel buckets containing $10 \mathrm{~L}$ aqueous solution of $3 \% \mathrm{SB}$. When needed, solutions were heated by placing the buckets in a $250-\mathrm{L}$ stainless steel water tank fitted with two electrical resistances $(4.5 \mathrm{~kW}$ each), a thermostat, and an automatic water-recirculating system. Fruit were placed into $18 \mathrm{~L}$ multi-perforated wall stainless steel containers, exactly fitting in the above mentioned buckets, and completely immersed in the treatment solution for $5,15,30,60$, or $150 \mathrm{~s}$ at $20,50,53,58,62,65$, or $68{ }^{\circ} \mathrm{C}$, although not all time-temperature combinations were tested. After treatment, the fruit were rinsed for $5 \mathrm{~s}$ with tap water at low pressure in order to eliminate SB salt residues. Control fruit were treated with water alone at $20^{\circ} \mathrm{C}$ for $60 \mathrm{~s}$. Each treatment was applied to 3 replicates of 25 fruit, which were arranged in plastic cavity sockets on cardboard trays. Treated fruit were incubated at $20{ }^{\circ} \mathrm{C}$ and $90 \% \mathrm{RH}$ for 7 days, at which time disease incidence was assessed. Three days after treatment, fruit were inspected for potential rind injuries caused by the treatments.

The same procedure was followed in further experiments to test the treatments on 'Clemenules' mandarins, 'Fino' lemons, and 'Ortanique' hybrid mandarins. Treatment conditions tested on these cultivars were chosen according to results previously obtained with 'Valencia' oranges. 


\subsection{Combination with low doses of imazalil}

Following the same procedure previously described for dip treatments, 'Valencia' oranges were inoculated with $10^{6}$ spores $\mathrm{mL}^{-1} P$. digitatum or $P$. italicum, held for $24 \mathrm{~h}$ at $20^{\circ} \mathrm{C}$ and $90 \% \mathrm{RH}$, and treated for $60 \mathrm{~s}$ dips in deionized water (control), $3 \% \mathrm{SB}, 25 \mu \mathrm{L} \mathrm{L}^{-1}$ active ingredient (a.i.) of IMZ (IMZ 25; ( \pm )-1-(2-(2,4-dichlorophenyl)-2-(2propenyloxy) ethyl)-1H-imidazole; Fecundal 7.5\% EC; Fomesa Fruitech S.L., Valencia, Spain), $50 \mu \mathrm{L} \mathrm{L}^{-1}$ a.i. IMZ (IMZ 50), or the combination of SB with each of the two concentrations of IMZ. For the combinations, aqueous solutions of both chemicals were mixed into $10 \mathrm{~L}$ buckets and manually stirred with a clean plastic rod. IMZ was used at two doses considerably lower than those recommended for commercial applications (500-1000 $\mu \mathrm{L} \mathrm{L}^{-1}$ a.i.). Tested temperatures were $20^{\circ} \mathrm{C}$ (except for the combination treatments) and $50{ }^{\circ} \mathrm{C}$. Fruit treated with SB were rinsed with tap water and left to dry before incubation at $20{ }^{\circ} \mathrm{C}$ and $90 \% \mathrm{RH}$. Each treatment was applied to 3 replicates of 20 fruit each. Disease incidence was determined after 7 days of incubation. Fruit phytotoxicities were assessed after 3 days at $20^{\circ} \mathrm{C}$. The experiment was performed twice.

2.5.1. Effectiveness on major citrus species and cultivars. Time and temperature conditions selected from the previous trials with 'Valencia' oranges were tested on other commercially important citrus species and cultivars. On the one hand, 'Clemenules' and 'Ortanique' mandarins were treated with water or $3 \% \mathrm{SB}$ for $60 \mathrm{~s}$ at $20,53,58$ or $62{ }^{\circ} \mathrm{C}$, and at 20 or $60{ }^{\circ} \mathrm{C}$, respectively. Likewise, 'Fino' lemons were treated with water at $20^{\circ} \mathrm{C}$ for $30 \mathrm{~s}$ (control treatment) or $3 \% \mathrm{SB}$ at 20 or $62{ }^{\circ} \mathrm{C}$, both for 15 or $30 \mathrm{~s}$. On the other hand, in order to study the compatibility with common postharvest treatments, 'Lanelate' oranges and 'Ortanique' mandarins were treated for $60 \mathrm{~s}$ with water or $25 \mu \mathrm{L} \mathrm{L}^{-1} \mathrm{IMZ}$ at $20^{\circ} \mathrm{C}$, or $25 \mu \mathrm{L} \mathrm{L}^{-1} \mathrm{IMZ}, 3 \% \mathrm{SB}$, or $3 \% \mathrm{SB}$ followed by $25 \mu \mathrm{L} \mathrm{L}^{-1} \mathrm{IMZ}$ at $50{ }^{\circ} \mathrm{C}$. Only fruit treated with SB alone was rinsed with tap water after treatment. Green and blue mold incidence was assessed after 7 days of incubation at $20^{\circ} \mathrm{C}$ and $90 \% \mathrm{RH}$.

2.5.2. Effectiveness of treatments during cold storage. 'Valencia' oranges were artificially inoculated with $P$. digitatum and $P$. italicum and then dip-treated for $60 \mathrm{~s}$ with water or aqueous solutions of $25 \mu \mathrm{L} \mathrm{L}^{-1}$ 
$\mathrm{IMZ}$ at $20{ }^{\circ} \mathrm{C}$, or $25 \mu \mathrm{L} \mathrm{L}^{-1} \mathrm{IMZ}, 3 \% \mathrm{SB}$, or $3 \% \mathrm{SB}$ followed by $25 \mu \mathrm{L} \mathrm{L}^{-}$

${ }^{1} \mathrm{IMZ}$ at $50{ }^{\circ} \mathrm{C}$. Only fruit treated with $\mathrm{SB}$ alone was rinsed with tap water after treatment. Treated fruit were stored for 8 weeks at $5{ }^{\circ} \mathrm{C}$ and $90 \% \mathrm{RH}$, then moved to a chamber at $20^{\circ} \mathrm{C}$ and $70-80 \% \mathrm{RH}$ and further held there for 7 days, simulating shelf-life. Green and blue mold incidence was assessed after $2,4,6$, and 8 weeks at $5^{\circ} \mathrm{C}$ and at the end of shelf-life.

\subsection{Preventive activity}

The efficacy of treatments with SB in the prevention of green mold was assessed on 'Valencia' oranges. Fruit were first dip treated with $3 \% \mathrm{SB}$ at $50{ }^{\circ} \mathrm{C}$ for $60 \mathrm{~s}$, and then inoculated, after $24 \mathrm{~h}$, with the tip of a stainless steel rod, $1 \mathrm{~mm}$ wide and $2 \mathrm{~mm}$ in length that had been immersed in a $10^{5}$ spores $\mathrm{mL}^{-1}$ conidial suspension of $P$. digitatum. Each treatment consisted of 3 replicates of 20 fruit each. After inoculation, treated fruit were incubated at $20{ }^{\circ} \mathrm{C}$ and $90 \% \mathrm{RH}$ for 7 days and then disease incidence was evaluated. The trial was performed twice.

\subsection{Statistical analysis}

Data on disease incidence $(\%)$ were transformed to the arcsine of the square root of the proportion of infected fruit to assure the homogeneity of variances. In some cases, reductions with respect to control treatments were calculated as percentages. Transformed data were analyzed by analysis of variance (ANOVA) with Statgraphics software (v. 5.1, Statpoint Technologies Inc., Warrenton, VA, USA). The level of significance was established at $P=0.05$. When appropriate, Fisher's Protected Least Significant Difference (LSD) test was used for means separation. Values displayed in graphs are non-transformed means. The term synergy was applied as defined by Richer (1987), where the effectiveness of a combination of treatments exceeds the prediction of the effectiveness of their additive action estimated by Limpel's formula $(\mathrm{Ee}=\mathrm{X}+\mathrm{Y}-(\mathrm{XY} / 100))$.

\section{Results}

3.1. In vivo primary screenings

Among the variety of food additives and concentrations tested in primary screenings, NaDHA at concentrations above $40 \mathrm{mM}$ and $\mathrm{SB}$ at 
concentrations of 100 or $200 \mathrm{mM}$ were the most effective treatments to reduce the incidence of both green and blue molds after both 3 and 6 days (Fig. 1) of incubation at $20{ }^{\circ} \mathrm{C}$ and $90 \% \mathrm{RH}$. Treatments with NaAc were slightly effective, even at very high doses of 600 to $1000 \mathrm{mM}$. Treatments with DMDC showed very poor efficacy against both pathogens, with disease reductions lower than $40 \%$ at concentrations as high as $600 \mathrm{mM}$. Similarly, treatments with EDTA were not generally effective, except when applied at $100 \mathrm{mM}$ against green mold, which was reduced by over $90 \%$ (Fig. 1). Rind phytotoxicity (dark blemishes or pitting on the rind area surrounding the inoculation site) was not observed for any of these treatments.

\subsection{Dip treatment conditions}

In accordance to the previous results, SB at $3 \%(\sim 200 \mathrm{mM})$ was selected to test the efficacy of this treatment in further dip applications. In tests with 'Valencia' oranges, treatments with SB were always more effective against green and blue molds than those with water alone applied at the same temperature for the same time (Fig. 2). SB dip treatment for only $5 \mathrm{~s}$ required very high application temperatures to be effective. Treatments with water applied for longer than $5 \mathrm{~s}$ reduced the incidence of green and blue molds proportionally to the dip temperature. This trend, although less marked, was also observed on fruit treated with SB. Thus, decay was strongly reduced on fruit treated with SB for 15 or $30 \mathrm{~s}$, even at dip temperatures of $20^{\circ} \mathrm{C}$, and rising the treatment temperature to $62^{\circ} \mathrm{C}$ only increased the efficacy of the treatments slightly. The lowest green and blue mold incidence was observed on fruit treated with SB at $62^{\circ} \mathrm{C}$ for $60 \mathrm{~s}$, with incidence values as low as 6 and $1 \%$, respectively, at the end of the incubation period. Increasing the duration of $\mathrm{SB}$ treatments at this temperature to $150 \mathrm{~s}$ did not substantially improve their efficacy. In general, SB efficacy was highly influenced by treatment temperature, showing a synergistic effect between these two factors (see asterisks on Fig. 2). With the exception of slight blemishes on the rind of 'Valencia' oranges treated at $62^{\circ} \mathrm{C}$ for 150 $\mathrm{s}$, no rind phytotoxicities were observed in these trials. 


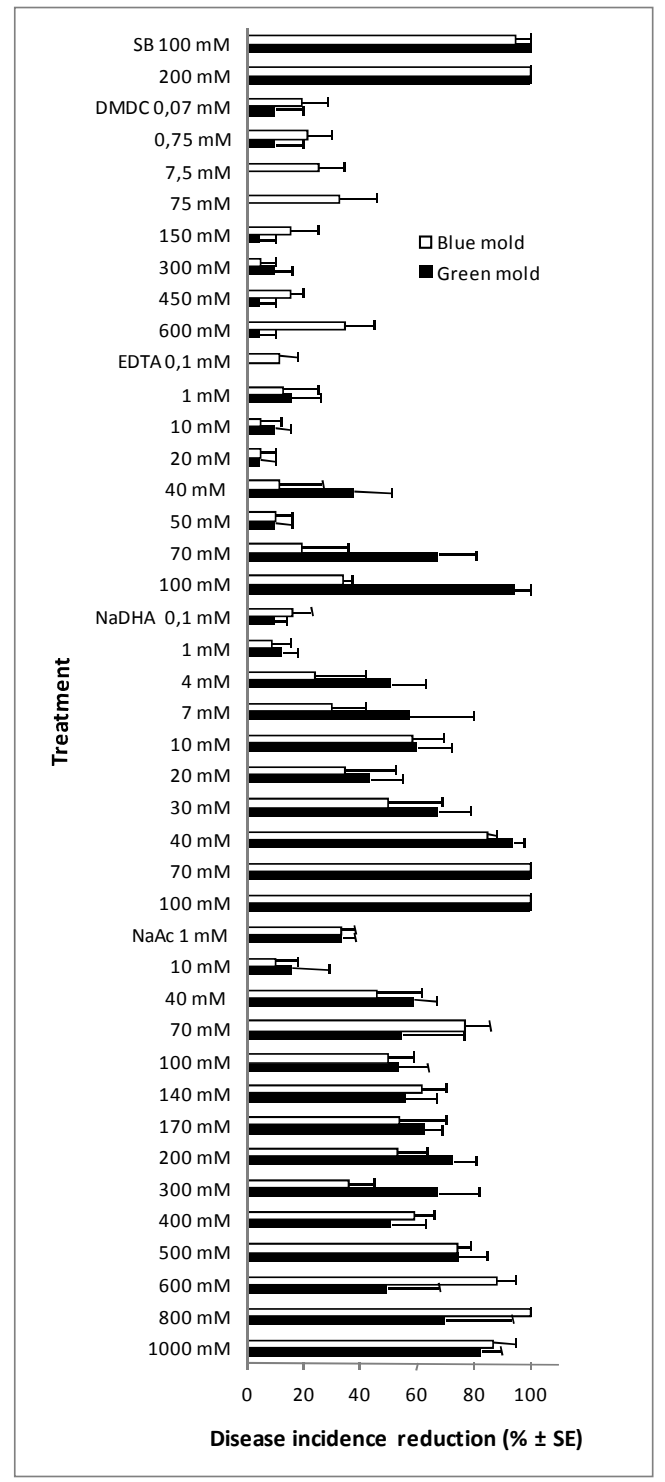

Fig. 1. Reduction of the incidence of green and blue molds on 'Valencia' oranges wound inoculated with $P$. digitatum and $P$. italicum, respectively, treated $24 \mathrm{~h}$ later by placing in the wound $30 \mu \mathrm{L}$ of aqueous solution at different concentrations of sodium benzoate (SB), ethylendiaminetetraacetic acid (EDTA), dehydroacetic acid sodium salt (NaDHA), sodium acetate (NaAc), or dimethyl dicarbonate (DMDC), and incubated at $20{ }^{\circ} \mathrm{C}$ for 6 days. Each combination of pathogen, substance, and concentration was applied to 4 replicates of 5 oranges and repeated twice $(n=12)$. 


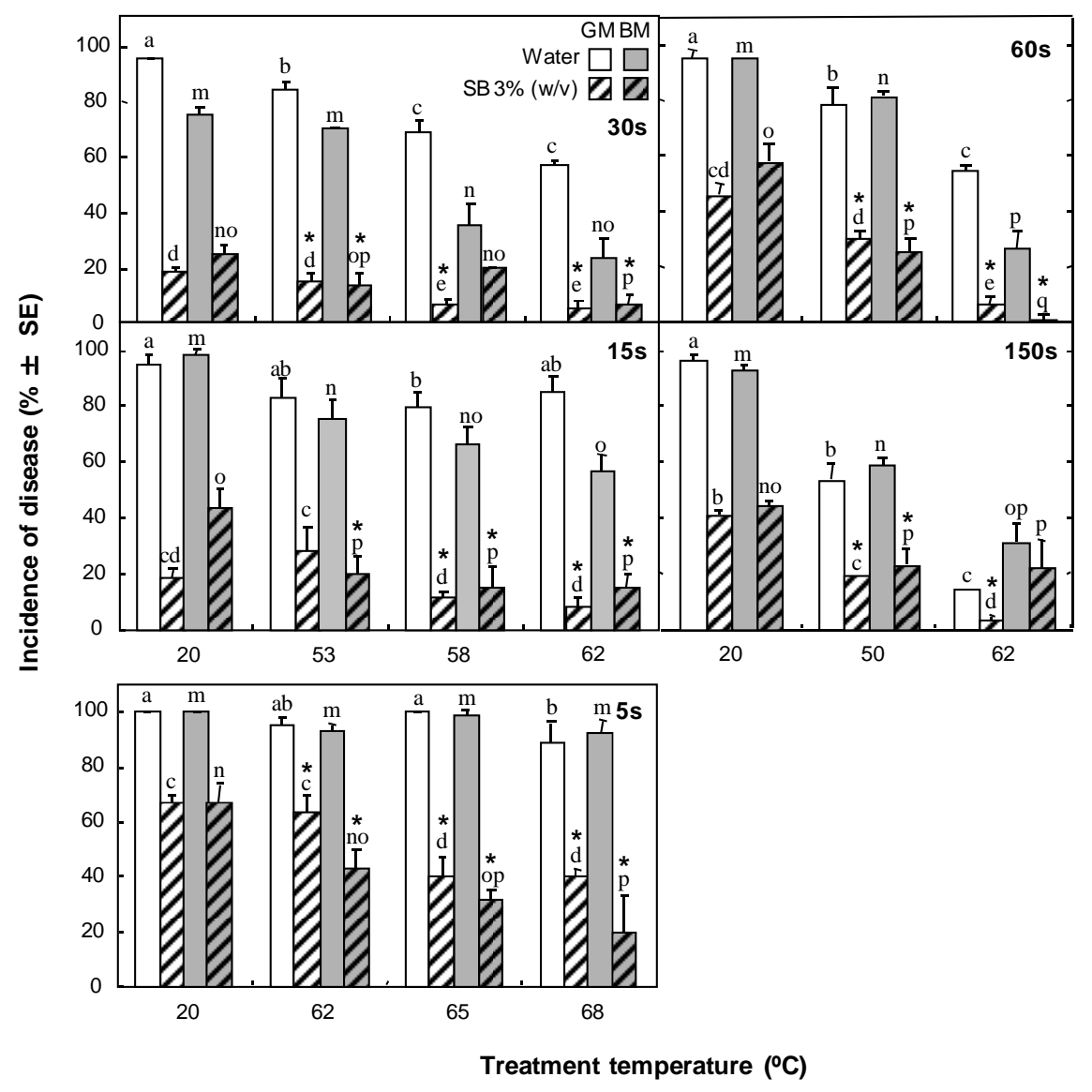

Fig. 2. Incidence of green (GM) and blue (BM) molds on 'Valencia' oranges wound inoculated with Penicillium digitatum and P. italicum, respectively, immersed $24 \mathrm{~h}$ later for different time periods in $3 \%(\mathrm{w} / \mathrm{v})$ sodium benzoate (SB) at different temperatures, and stored for 7 days at $20{ }^{\circ} \mathrm{C}$ and $90 \% \mathrm{RH}$. For each immersion time and pathogen, columns with unlike letters $(a-d$ for GM and $m-p$ for BM) differ significantly according to Fisher's protected LSD test $(P \leq 0.05)$ applied after an ANOVA to arcsine-transformed values. Nontransformed means are shown. Each treatment was applied to 3 replicates of 25 fruit $(n=3) .(*)$ Synergistic effect between temperature and SB according to Limpel's formula. 


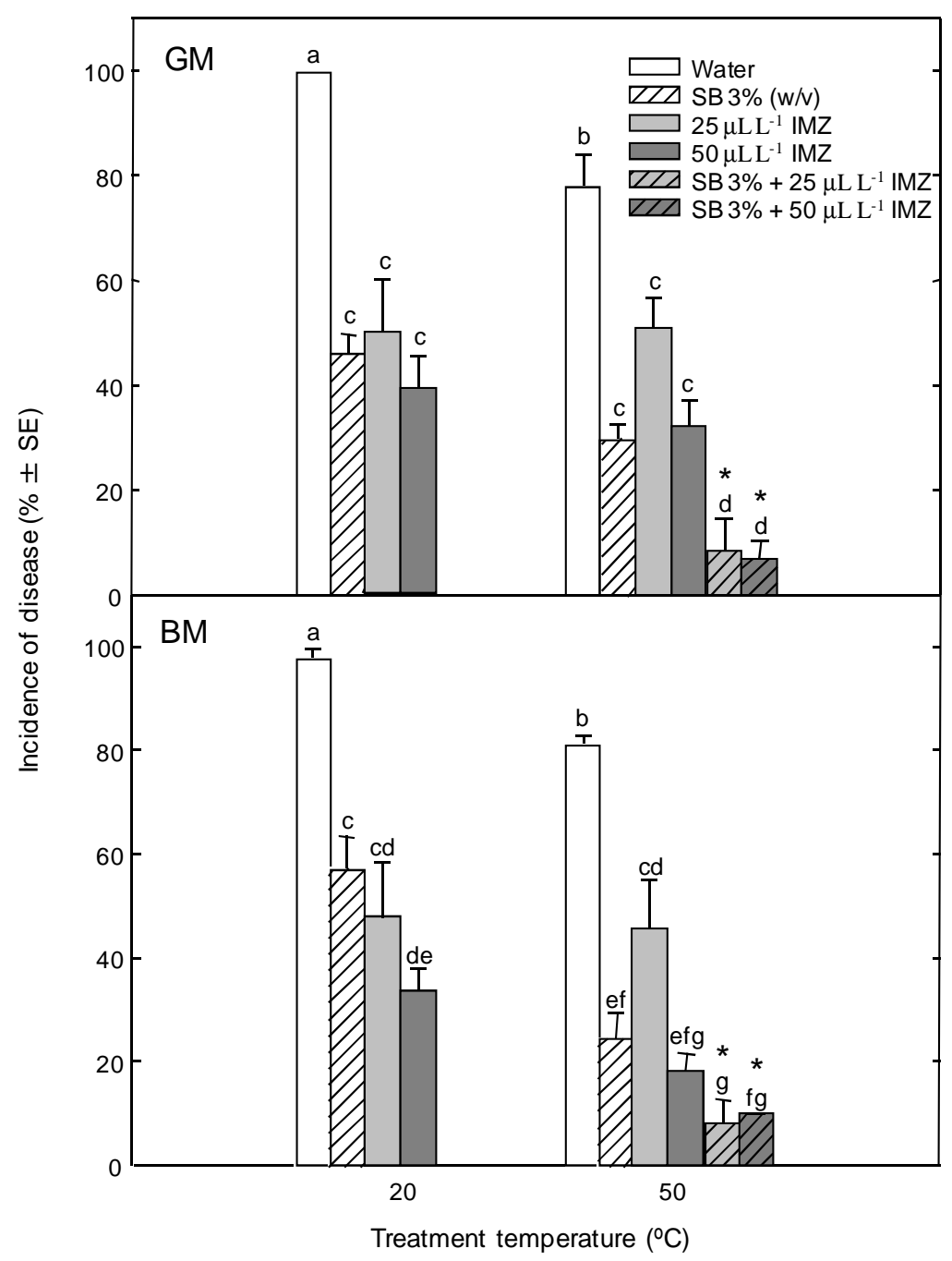

Fig. 3. Incidence of green (GM) and blue (BM) molds on 'Valencia' oranges wound inoculated with Penicillium digitatum and $P$. italicum, respectively, immersed $24 \mathrm{~h}$ later in water (control), $3 \%$ (w/v) sodium benzoate (SB), 25 or $50 \mu \mathrm{L} \mathrm{L}^{-1}$ imazalil (IMZ), or SB combined with IMZ at the indicated temperature, and stored for 7 days at $20{ }^{\circ} \mathrm{C}$ and $90 \%$ RH. For each pathogen, columns with unlike letters differ significantly according to Fisher's protected LSD test $(P \leq 0.05)$ applied after an ANOVA to arcsine-transformed values. Non-transformed means are shown. Each treatment was applied to 3 replicates of 20 fruit and repeated once $(n=6)$. (*) Synergistic effect between SB and IMZ according to Limpel's formula.. 


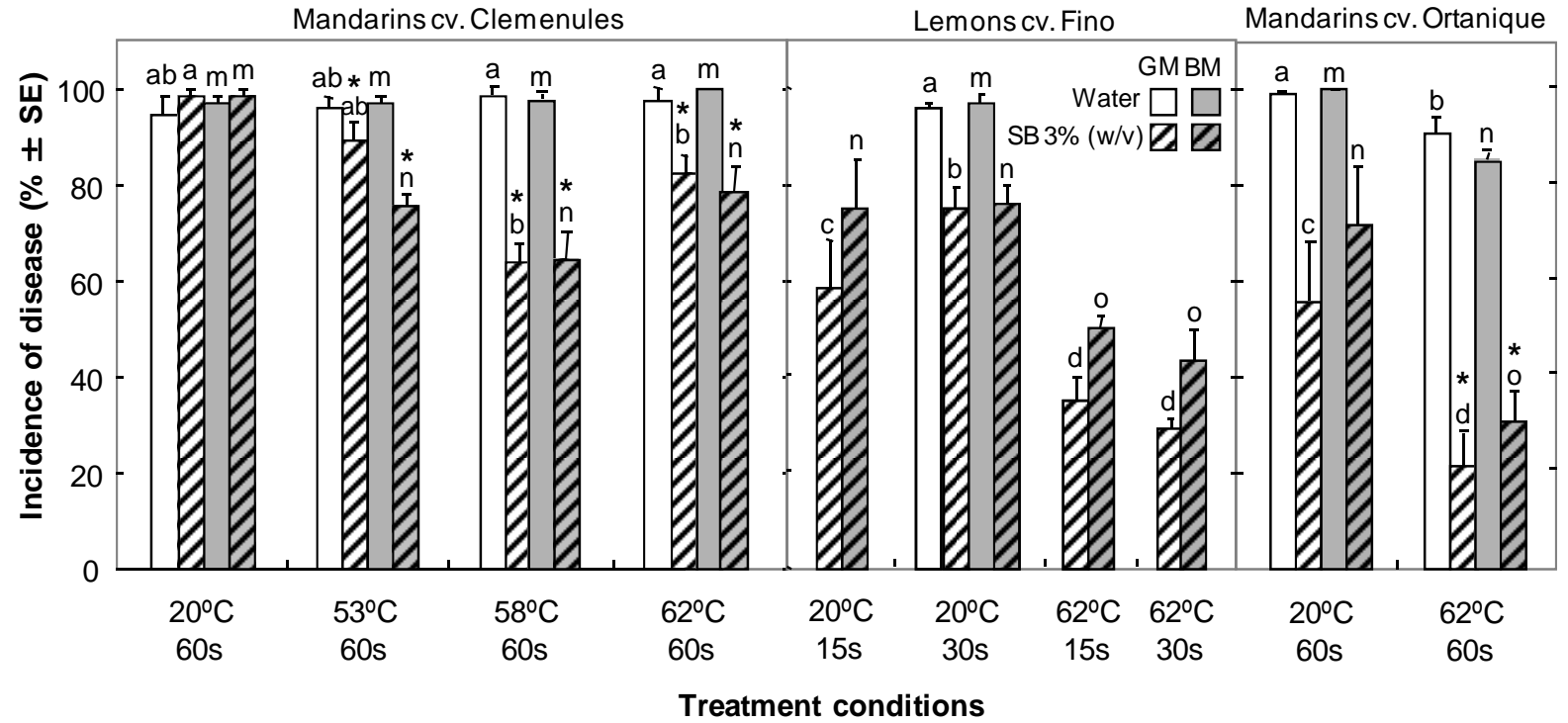

Fig. 4. Incidence of green (GM) and blue (BM) molds on 'Clemenules' and 'Ortanique' mandarins and 'Fino' lemons inoculated with Penicillium digitatum and P. italicum, respectively, immersed in water (control), or 3\% (w/v) sodium benzoate (SB), at the indicated temperature for the indicated time, and stored for 7 days at $20{ }^{\circ} \mathrm{C}$ and $90 \%$ RH. For each cultivar and pathogen, columns with unlike letters ( $a-d$ for GM and $m-p$ for BM) differ significantly according to Fisher's protected LSD test $(P \leq 0.05)$ applied after an ANOVA to arcsine-transformed values. Non-transformed means are shown. Each treatment was applied to 3 replicates of 25 fruit $(n=3)$. $\left(^{*}\right)$ Synergistic effect between temperature and SB according to Limpel's formula. 


\subsection{Combination with low doses of imazalil}

Dip treatments with $3 \%(\mathrm{w} / \mathrm{v}) \mathrm{SB}$ at $20^{\circ} \mathrm{C}$ for $60 \mathrm{~s}$ reduced green and blue mold incidence from $100 \%$ on control fruit to less than 50 and $60 \%$, respectively (Fig. 3). Treatments with IMZ at concentrations of 25 or 50 $\mu \mathrm{L} \mathrm{L}{ }^{-1}$ were not more effective than SB treatments applied at the same temperature for the same time. Heating dip solutions to $50^{\circ} \mathrm{C}$ generally improved the efficacy of all treatments, including water alone, against both target diseases, although the differences were not always statistically significant. The incidence of both green and blue molds was greatly reduced on 'Valencia' oranges treated with 3\% SB combined with 25 or $50 \mu \mathrm{L} \mathrm{L}^{-1} \mathrm{IMZ}$, with no significant differences between treatments. In all cases, the efficacy of combined treatments was higher than the expected by the mere addition of individual efficacies, showing a synergistic effect according to Limpel's formula (Fig. 3). None of the tested treatments at any temperature was visibly phytotoxic to 'Valencia' oranges.

3.3.1. Effectiveness on major citrus species and cultivars. On 'Clemenules' mandarins, treatments with $3 \% \mathrm{SB}$ for $60 \mathrm{~s}$ were not effective for the control of green and blue molds when applied at $20^{\circ} \mathrm{C}$ (Fig. 4). Regardless of treatment temperature, all treatments with water were ineffective to control green and blue molds, being disease incidence always close to $100 \%$. Heating solutions to $53^{\circ} \mathrm{C}$ increased the efficacy of the dips for blue mold, but not for green mold. Disease incidence was also significantly lower on fruit treated at 58 or $62^{\circ} \mathrm{C}$, but with reductions of both molds of only around 30\%. On 'Fino' lemons, the incidence of green and blue molds was not highly reduced after treatments with $3 \%$ $\mathrm{SB}$ at $20^{\circ} \mathrm{C}$ irrespective of dip duration, and most fruit showed disease incidence of around $75 \%$, while decay on fruit of the unique control treatment performed with this citrus species (water at $20^{\circ} \mathrm{C}$ for $30 \mathrm{~s}$ ) was close to $100 \%$. Increasing the temperature of SB aqueous solutions to $62^{\circ} \mathrm{C}$ reduced green and blue mold incidence on treated lemons to approximately 30 and $50 \%$, respectively, with respect to the control treatment of water at $20^{\circ} \mathrm{C}$. For these $\mathrm{SB}$ solutions heated to $62^{\circ} \mathrm{C}$, no significant differences were observed between treatment durations of 15 and 30 s. Likewise, on 'Ortanique' mandarins, treatments with SB at $20^{\circ} \mathrm{C}$ for $60 \mathrm{~s}$ reduced green and blue molds incidence by 40 and $30 \%$, respectively. The efficacy of the treatments increased when applied at 
$62^{\circ} \mathrm{C}$, reducing the incidence of green and blue molds to 20 and $30 \%$, respectively. According to Limpel's formula, the two factors, temperature and SB concentration, were synergistic in mandarins (Fig. 4). Synergy was not analyzed in lemons since treatments with heated water alone were not performed. The tested dip conditions did not cause any visible phytotoxicity on the fruit rind.

$\mathrm{SB}$ at $3 \%$ in combination with low doses of IMZ $\left(25 \mu \mathrm{L} \mathrm{L}^{-1}\right)$ was studied on 'Lanelate' oranges and 'Ortanique' mandarins. Incidence of both green and blue molds on 'Lanelate' oranges treated with water at $20^{\circ} \mathrm{C}$ for $60 \mathrm{~s}$ (control) was $100 \%$ after 7 days of incubation (Fig. 5). Incidence of green and blue molds was reduced by around 80 and $70 \%$, respectively, on oranges treated with either IMZ alone at 20 or $50^{\circ} \mathrm{C}$ or $\mathrm{SB}$ at $50^{\circ} \mathrm{C}$. Decay incidence on oranges treated with the combination of $\mathrm{SB}$ and $\mathrm{IMZ}$ at $50^{\circ} \mathrm{C}$ was as low as $5 \%$, showing a synergistic effect between these two treatments, according to Limpel's formula. The same pattern was observed when 'Ortanique' mandarins were treated following identical procedures. In this case, treatments with either IMZ or SB alone were less effective than on 'Lanelate' oranges, although the combined treatment reduced disease incidence to a lower extent ( 2 and $4 \%$ incidence of green and blue molds, respectively), showing a stronger synergism between SB and IMZ (Fig. 5).

3.3.2. Effectiveness of treatments during cold storage. 'Valencia' oranges inoculated with $P$. digitatum or $P$. italicum and treated with water at $20^{\circ} \mathrm{C}$ (control) showed high levels of decay after the first two weeks of storage at $5^{\circ} \mathrm{C}$, being the incidence of green and blue molds around 96 and 88\%, respectively (Fig. 6). At this time, the incidence of both green and blue molds was around $10 \%$ on fruit treated with $25 \mu \mathrm{L} \mathrm{L}^{-}$ ${ }^{1} \mathrm{IMZ}$ at $20^{\circ} \mathrm{C}$, and close to zero on oranges treated with $25 \mu \mathrm{L} \mathrm{L}^{-1} \mathrm{IMZ}$, $3 \% \mathrm{SB}$, or the combination of both chemicals at $50{ }^{\circ} \mathrm{C}$. On fruit treated with IMZ or SB alone, the incidence of green and blue molds gradually increased along storage time and even more after 1 additional week at room temperature, when final incidence of green and blue molds was respectively 45 and $55 \%$ for $\mathrm{IMZ}$ at $20^{\circ} \mathrm{C}, 27$ and $42 \%$ for $\mathrm{SB}$ at $50^{\circ} \mathrm{C}$, and both $28 \%$ for IMZ at $50{ }^{\circ} \mathrm{C}$. Nevertheless, the incidence of both diseases remained close to zero on oranges treated with the combination of SB and IMZ at $50{ }^{\circ} \mathrm{C}$ at the end of the cold storage period and shelf- 
life. Again, this latter treatment showed a high synergism between IMZ and SB according to Limpel's formula (Fig. 6).

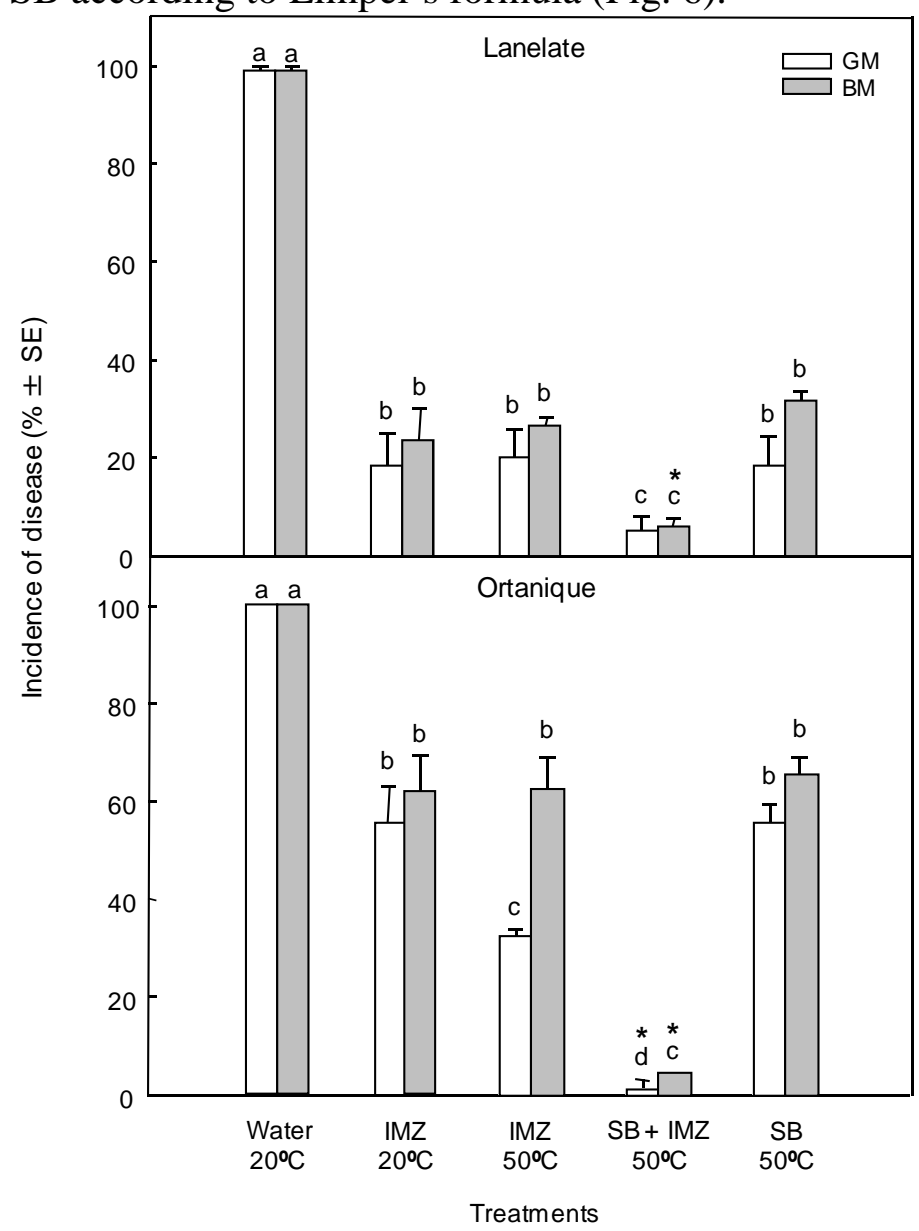

Fig. 5. Incidence of green (GM) and blue (BM) molds on 'Ortanique' mandarins and 'Lanelate' oranges inoculated with of Penicillium digitatum and $P$. italicum, respectively, immersed for $60 \mathrm{~s}$ in water (control), $3 \%(\mathrm{w} / \mathrm{v})$ sodium benzoate (SB), $25 \mu \mathrm{L} \mathrm{L}^{-1}$ imazalil (IMZ), or SB combined with IMZ at the indicated temperature, and stored for 7 days at $20^{\circ} \mathrm{C}$ and $90 \% \mathrm{RH}$. For each pathogen, columns with unlike letters differ significantly according to Fisher's protected LSD test $(P \leq 0.05)$ applied after an ANOVA to arcsine-transformed values. Non-transformed means are shown. Each treatment was applied to 3 replicates of 20 fruit $(n=3)$. (*) Synergistic effect between SB and IMZ according to Limpel's formula. 


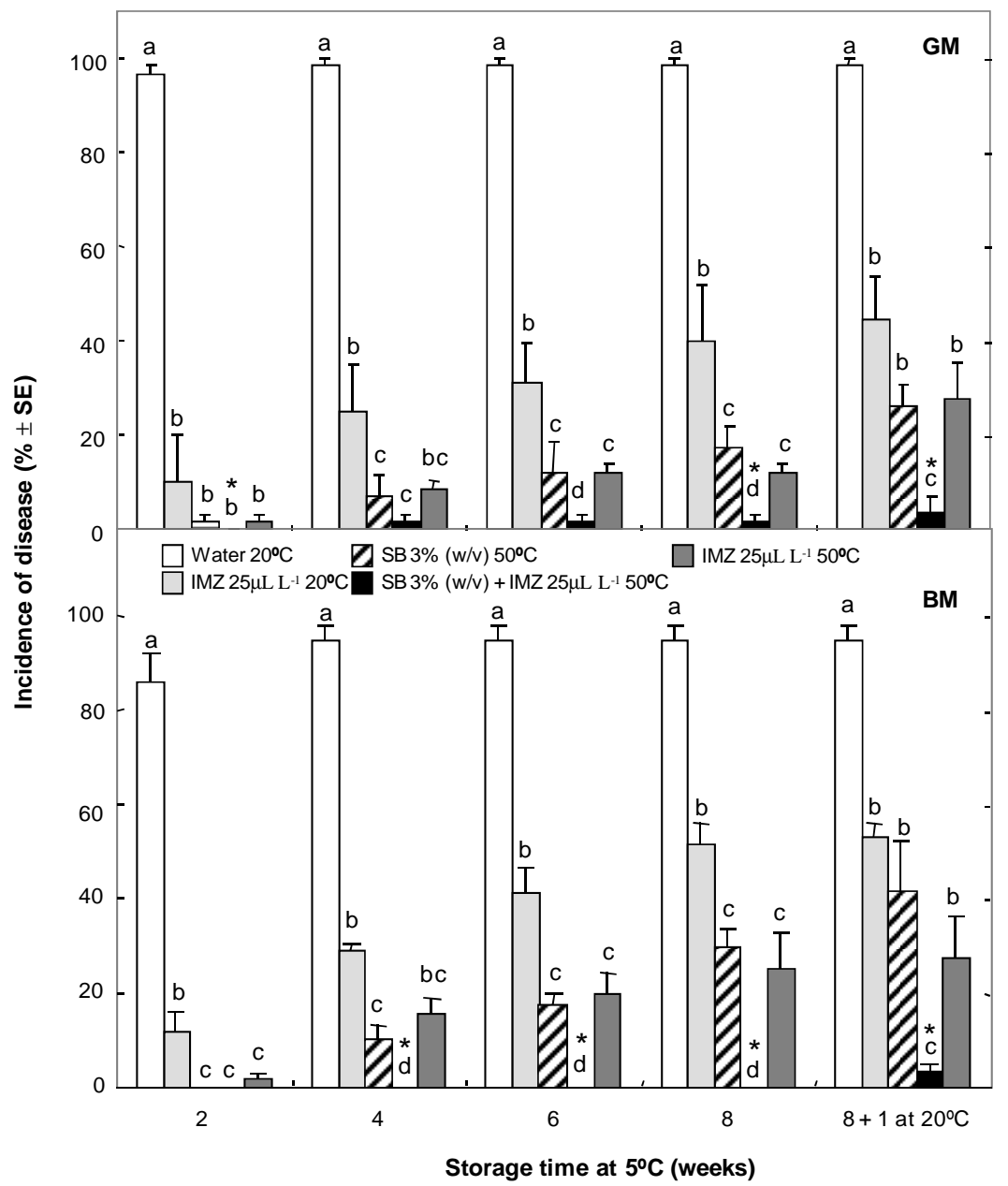

Fig. 6. Incidence of green (GM) and blue (BM) molds on 'Valencia' oranges inoculated with Penicillium digitatum and $P$. italicum, respectively, immersed for $60 \mathrm{~s}$ in water (control) or $25 \mu \mathrm{L} \mathrm{L}^{-1}$ imazalil (IMZ) at $20^{\circ} \mathrm{C}$, or $3 \%(\mathrm{w} / \mathrm{v}$ ) sodium benzoate (SB), $25 \mu \mathrm{L} \mathrm{L}^{-1} \mathrm{IMZ}$, or the mixture of SB and IMZ at $50{ }^{\circ} \mathrm{C}$, and stored for 8 weeks at $5{ }^{\circ} \mathrm{C}$ and $90 \%$ RH followed by 7 days of shelf-life at $20{ }^{\circ} \mathrm{C}$ and $70-80 \%$ RH. For each pathogen, columns with unlike letters differ significantly according to Fisher's protected LSD test $(P \leq 0.05)$ applied after an ANOVA to arcsine-transformed values. Non-transformed means are shown. Each treatment was applied to 3 replicates of 20 fruit $(n=3)$. (*) Synergistic effect between SB and IMZ according to Limpel's formula. 


\subsection{Preventive activity}

SB treatments were not effective in reducing green mold incidence when applied about $24 \mathrm{~h}$ before wound inoculation with $P$. digitatum (data not shown).

\section{Discussion}

In this study, the antifungal properties of five food additives were tested at a wide range of concentrations in primary screening tests on fruit inoculated with $P$. digitatum or $P$. italicum. It has been reported that, as a pathogenicity mechanism, the secretion of organic acids by the pathogens varies when it is produced in vitro and in vivo (Prusky et al., 2004), which could presumably alter the toxicity of antifungal treatments with food additives or other compounds. For instance, notable differences in efficacy between in vivo and in vitro tests have been observed in experiments with carbonates against citrus green mold (Smilanick et al., 1999). Therefore, in vivo primary screenings with citrus fruit instead of in vitro assays were selected in this study to preliminary assess the efficacy of different food additives and concentrations. Among the tested substances (SB, NaDHA, NaAc, DMDC, and EDTA), SB at 100 and 200 $\mathrm{mM}, \mathrm{NaDHA}$ at 70 and $100 \mathrm{mM}$, and $\mathrm{NaAc}$ at 800 and $1000 \mathrm{mM}$ reduced green and blue molds by $80 \%$ or higher. Required NaAc concentrations were too high and unpractical, and even less effective than lower concentrations of SB or NaDHA. SB parental chemical benzoic acid and the related compound benzyl benzoate are registered by US EPA as insecticides and fungicides. Moreover, while SB is approved in the EU for use in foods, the status of NaDHA has been revisited due to its more toxic profile (Kegley et al., 2014). These facts accounted for the choice of SB to be used in subsequent trials to assess the efficacy of dip treatments. Although the differences between 100 and $200 \mathrm{mM} \mathrm{SB}$ were not significant, SB at $200 \mathrm{mM}$ was slightly more effective against blue mold than at $100 \mathrm{mM}$. Further, previous studies showed that SB at 200 $\mathrm{mM}$ was an effective treatment against postharvest pathogens of stone fruit (Palou et al., 2009). For these reasons, this concentration of approximately $3 \%$ SB was selected to be tested in further trials.

In general in the present study, SB dip treatments controlled green and blue molds more effectively on oranges than on mandarins after identical treatments applied at the same conditions. In all tests, decay on control 
fruit was high and similar on both oranges and mandarins, so differences in efficacy were not caused by mere differences in fruit susceptibility to decay. Disease development results from complex interactions between fruit, pathogen and environment. Efficacy of antifungal food additives depends on the amount of salt residue present within wound infection courts occupied by the fungus and on interactions between this residue and rind constituents. Apparently, such interactions may be different in oranges and mandarins as a consequence of different rind characteristics or composition. In prior research, the efficacy of treatments with hot water, sodium carbonate, sodium bicarbonate (Palou et al., 2001, 2002), potassium sorbate (Montesinos-Herrero et al., 2009) or sodium parabens (Moscoso-Ramírez et al., 2013a,b, 2014) against green and blue molds was also lower on mandarins than oranges. On the other hand, the effectiveness of 3\% SB applied as aqueous dips was considerably lower than that obtained in in vivo primary screenings (incidence reductions of $100 \%$; Fig. 1). This was possibly due to the increased contact time of the SB drop with the rind wound inoculated with $P$. digitatum or $P$. italicum with respect to the contact time of dip treatments. In fact, contact time or dip duration was an influencing factor on the effectiveness of SB treatments applied on 'Valencia' oranges (Fig. 2).

The antimicrobial effect of SB has been widely reviewed and, in particular, several studies showed its efficacy as antifungal postharvest treatment on citrus (Hall, 1988), stone fruits (Palou et al., 2009), or longan fruit (Yahia, 2011). In the present work, different dip conditions (duration and temperature) were tested in order to optimize dip applications of SB. High temperatures tested ranged from 50 to $62{ }^{\circ} \mathrm{C}$ because synergistic effects between these temperatures and alternative chemicals such as sodium carbonate or potassium sorbate had been previously observed; lower temperatures were less effective and higher temperatures led to visible phytotoxicities on the fruit rind (Smilanick et al., 1999; Montesinos-Herrero et al., 2009). The combination of SB with heat was synergistic and SB treatments at higher temperatures were more effective against green and blue molds in all cultivars tested (Figs. 2, 4). This was observed in previous studies with other food aditives such as carbonates (Palou et al., 2001) or potassium sorbate (Montesinos-Herrero et al., 2009), but not with other compounds such as potassium silicate (Moscoso-Ramírez and Palou, 2014) or sodium methyl- (Moscoso- 
Ramírez et al., 2013a), ethyl- (Moscoso-Ramírez et al., 2013b) or propyl(Moscoso-Ramírez et al., 2014) parabens. It was concluded in these cases that the potential benefits from heating the solutions did not compensate for the potential commercial costs. Synergistic effects between SB and heat were also dependent on the citrus cultivar. The efficacy of heated SB solutions was not as high on 'Clemenules' mandarins than on other citrus species and cultivars, probably due to a higher sensitivity of this cultivar to hot water dips, which may adversely affect the skin of the fruit and made it more susceptible to fungal development. It is actually found in the literature that hot water dip treatments were less effective as antifungal treatments on mandarins than on oranges (Schirra et al., 1998; Palou et al., 2001, 2002). Immersion time is an important factor influencing efficacy, with higher control achieved by longer treatments. However, commercial conditions during fruit manipulation in citrus packinghouses do not allow prolonged treatment times and thus, times from 5 to $150 \mathrm{~s}$ were chosen. As expected, longer treatments yielded higher efficacies against green and blue molds (Fig. 2). However, the efficacy of SB treatments applied for 60 or $150 \mathrm{~s}$ was not different enough to select the longest immersion time. It is clear that, at the commercial level, longer dip treatments lead to an increase in energy costs and risks of phytotoxicity in sensitive cultivars.

Dip treatments with 3\% SB reduced green and blue mold incidence to a similar extent than dip treatments with low doses of IMZ. The combinations of SB with IMZ consistently improved the efficacy of these treatments and always showed a synergistic effect (Figs. 3, 5, 6). This effect was particularly marked when treated fruit were stored at low temperatures (Fig. 6). The observed synergism between SB and IMZ is presumably due to the different modes of action of these chemicals, which are more lethal when acting together. In addition, both substances were more effective when applied at higher temperatures, which favored their synergism. It is known that IMZ, like the rest of fungicides in the imidazole family, inhibits ergosterol synthesis in fungi by blocking C-14 demethylation (Van den Bossche et al., 1978; Siegel and Ragsdale, 1978; Henry and Sisler, 1979). This results in accumulation of C-14 methyl sterol intermediates, such as lanosterol, and a decrease in ergosterol, with the subsequent deterioration of the cell membrane. Moreover, heat increases the level of IMZ residues in the fruit rind, probably due to 
partial melting and remodeling of the wax layer by heat, resulting in the disappearance of cracks in this layer and in trapping of the active ingredient (Schirra et al., 1997). On the other hand, it has been demonstrated that in acidic medium such as the wounded rind of citrus fruit, the undissociated form of the benzoic acid (to which the yeast cell membrane is permeable) enters the cell until the concentration equals inside and outside the cell (Restaino et al., 1981; Krebs et al., 1983). The neutralization of the undissociated form by cell buffers causes an acidification inside the cell that ultimately inhibits cell growth. The fall in intracellular $\mathrm{pH}$ caused by the accumulation of benzoic acid at low external $\mathrm{pH}$ inhibits glycolysis at the stage of phosphofructokinase, thus depleting the cell of ATP and in consequence restricting its growth (Krebs et al., 1983). The observed synergism between heat and SB treatments seems to indicate that high temperatures improve the mode of action of SB by increasing the permeability of the membrane, facilitating the entrance of $\mathrm{SB}$, a $\mathrm{pH}$ reduction and the formation of benzoic acid (Rushing and Senn, 1963). Different and complementary modes of action of IMZ and SB may account for their synergism when applied together against green and blue molds.

The use of SB in postharvest applications for fresh horticultural produce may have the same level of allowance by authorities than potassium sorbate, since SB is also a food additive authorized by EU and USA regulations. Potassium sorbate is currently accepted as postharvest treatment for citrus fruit, with an MRL of $20 \mathrm{mg} \mathrm{kg}^{-1}$ (EC, 2010). At present, SB, benzoic acid, potassium benzoate and calcium benzoate are authorized food additives in the EU. They can be used up to $150 \mathrm{mg} \mathrm{kg}^{-1}$ in traditional Swedish and Finnish fruit syrups and flavored drinks excluding dairy-based drinks; up to $200 \mathrm{mg} \mathrm{kg}^{-1}$ in Danish juice sweet, alcohol-free wine and beer, and aspic; up to $500 \mathrm{mg} \mathrm{kg}^{-1}$ in olives and olive-based preparations, seaweed preparations, low-sugar and similar low calorie or sugar-free marmalades and other fruit-based spreads; up to $1000 \mathrm{mg} \mathrm{kg}^{-1}$ quince paste and cooked crustaceans and mollusks; up to $1500 \mathrm{mg} \mathrm{kg}^{-1}$ in cooked shrimps in brine, and up to $2000 \mathrm{mg} \mathrm{kg}^{-1}$ in cooked red beet (EC, 2015). In the USA, SB and benzoic acid are included in the Food and Drug Administration (FDA) list of GRAS substances. Both may be used as antimicrobial agents, flavoring agents, 
and as adjuvants with a current maximum level of $0.1 \%$ in food (US FDA, 2001).

In the present research, SB alone or combined with low doses of IMZ showed very high efficacy for the control of citrus green and blue molds. This kind of treatments with low or no use of synthetic fungicides is very demanded by general consumers and especially by most fruit distributors in the EU and worldwide. In addition, the different mode of action of SB could be an important additional tool to hinder the proliferation of IMZ resistant strains of $P$. digitatum and $P$. italicum, which is at present a common important issue in most citrus packinghouses. In this sense, the use of SB would allow the fight against resistances without the addition of other synthetic fungicides in the packinghouse disease management program. Treatments tested in this study, including those using high temperatures, are currently feasible to be applied at the commercial level in many modern Spanish and worldwide citrus packinghouses. Heated solutions of SB alone satisfactorily controlled green and blue mold on oranges, even when treated fruit were cold-stored. However, on mandarins and lemons, the combination of SB with low doses of IMZ was necessary to reduce disease incidence to commercially acceptable levels. In this case, combinations with control methods other than synthetic fungicides should be tested in order to improve SB efficacy and offer alternative treatments for markets with zero tolerance to fungicide residues. After these laboratory and small-scale trials with artificially inoculated, large-scale trials in citrus packinghouses with naturally infected fruit should be conducted to confirm the potential of SB treatments against green and blue molds and justify the registration of this compound for postharvest commercial use.

\section{Acknowledgements}

Federico Izquierdo and Fontestad S.A. (Montcada, València) are gratefully acknowledged for providing fruit. This work was partially funded by the Spanish 'Ministerio de Educación y Ciencia' (MEC; project AGL2004-05271) and the European Union (FEDER Program). Clara Montesinos-Herrero's doctorate program was supported by the IVIA. In memory of Dr. Miguel Ángel del Río, for his guidance and support and for his unconditional friendship. 


\section{References}

Askarne, L., Talibi, I., Boubaker, H., Serghin, M.A., Boudyach, E.H., Ait Ben Aoumar, A., 2011. Effects of organic acids and salts on the development of Penicillium italicum: The causal agent of citrus blue mold. Plant Pathology Journal 10, 99-107.

Bautista-Baños, S. (ed.), 2014. Postharvest Decay. Control Strategies. 1st ed. Academic Press, Elsevier. London, UK.

Brown, G.E., 1985. Effectiveness of postharvest fungicides for the control of citrus fruit decays. Proceedings of the Florida State Horticultural Society 98, 208-211.

Bus, V.G., Bongers, A.J., Risse, L.A., 1991. Occurrence of Penicillium digitatum and $P$. italicum resistant to benomyl, thiabendazole, and imazalil on citrus fruit from different geographical origins. Plant Disease 75, 1098-1100.

Cunningham, N., 2010. Combinations of treatments to replace the use of conventional fungicides for the commercial control of postharvest diseases of citrus fruit. Stewart Postharvest Review 1:2, 1-8.

D’Aquino, S., Palma, A., Angioni, A., Schirra, M., 2013. Residue levels and efficacy of fludioxonil and thiabendazole in controlling postharvest green mold decay in citrus fruit when applied in combination with sodium bicarbonate. Journal of Agricultural and Food Chemistry 61, 296-306.

EC (European Commission), 2010. Commission Directive No 2010/69/EC modifying annexes of Directive 95/2/EC relative to food additives other than colorants and sweeteners. Official Journal No. L279, 22-31.

EC (European Commission), 2015. Database on Food Additives. Online: https://webgate.ec.europa.eu/sanco_foods/main/index.cfm?sector=FA D\&auth=SANCAS

Eckert, J.W., Eaks, I.L., 1989. Postharvest disorders and diseases of citrus fruits. In: Reuter, W., Calavan, E.C., Carman, G.E. (eds.), The Citrus Industry. Division of Agriculture and Natural Resources, University of California Press, Berkeley, CA, USA.

Eckert, J.W., Sievert, J.R., Ratnayake, M., 1994. Reduction of imazalil effectiveness against citrus green mold in California packinghouses by resistant biotypes of Penicillium digitatum. Plant Disease 78, 971-974. 
Erasmus, A., Lennox, C.L., Smilanick, J.L., Lesar, K., Fourie, P.H., 2013. Imazalil residue loading and green mould control on citrus fruit as affected by formulation, solution $\mathrm{pH}$ and exposure time in aqueous dip treatments. Postharvest Biology and Technology 77, 43-49.

Hall, D.J., 1988. Comparative activity of selected food preservatives as citrus postharvest fungicides. Proceedings of the Florida State Horticultural Society 101, 184-187.

Henry, M.J., Sisler, H.D., 1979. Effects of miconazole and dodecylimidazole on sterol biosybthesis in Ustilago maydis. Antimicrobial Agents and Chemotherapy 15, 603-607.

Holmes, G.J., Eckert, J.W., 1995. Relative fitness of imazalil-resistant and -sensitive biotypes of Penicillium digitatum. Plant Disease 79, 1068-1073.

Ippolito, A., Schena, L., Pentimone, I., Nigro, F., 2005. Control of postharvest rots of sweet cherries by pre- and postharvest applications of Aureobasidium pulllulans in combination with calcium chloride or sodium bicarbonate. Postharvest Biology and Technology 36, 245252.

Janisiewicz, W.J., Conway, W.S., 2010. Combining biological control with physical and chemical treatments to control fruit decay after harvest. Stewart Postharvest Review 1:3, 1-16.

Kegley, S.E., Hill, B.R., Orme, S., Choi, A.H., 2014. PAN Pesticide Database. Online: http:www.pesticideinfo.org.

Kinay, P., Mansour, M.F., Mlikota-Gabler, F., Margosan, D.A., Smilanick, J.L., 2007. Characterization of fungicide-resistant isolates of Penicillium digitatum collected in California. Crop Protection 26, 647-656.

Krebs, H.A., Wiggins, D., Stubbs, M., Sols, A., and Bedoya, F. 1983. Studies on the mechanism of the antifungal action of benzoate. Biochemistry Journal 214, 657 - 663.

Montesinos-Herrero, C., Palou, L., 2010. Combination of physical and low-toxicity chemical postharvest treatments for integrated disease management of citrus fruit: a review. Stewart Postharvest Review 1:1, $1-11$.

Montesinos-Herrero, C., del Río, M.A., Pastor, C., Brunetti, O., Palou, L., 2009. Evaluation of brief potassium sorbate dips to control 
postharvest penicillium decay on major citrus species and cultivars. Postharvest Biology and Technology 52, 117-125.

Moscoso-Ramírez, P.A., Montesinos-Herrero, C., Palou, L., $2013 \mathrm{a}$. Characterization of postharvest treatments with sodium methylparaben to control citrus green and blue molds. Postharvest Biology and Technology 77, 128-137.

Moscoso-Ramírez, P.A., Montesinos-Herrero, C., Palou, L., 2013 b. Control of citrus postharvest penicillium molds with sodium ethylparaben. Crop Protection 46, 44-51.

Moscoso-Ramírez, P.A., Montesinos-Herrero, C., Palou, L., 2014. Antifungal activity of sodium propylparaben alone or in combination with low doses of imazalil against Penicillium decay on citrus fruit. European Journal of Plant Pathology 140, 145-157.

Moscoso-Ramírez, P.A., Palou, L., 2014. Preventive and curative activity of postharvest potassium silicate treatments to control green and blue molds on orange fruit. European Journal of Plant Pathology 138, 721732.

Palou, L. 2014. Penicillium digitatum, Penicillium italicum (Green Mold, Blue mold). In: Bautista-Baños, S. (ed.), Postharvest Decay. Control Strategies. 1st ed. Academic Press, Elsevier. London, UK. pp. 45-102.

Palou, L., Smilanick, J.L., Crisosto, C.H., 2009. Evaluation of food additives as alternative or complementary chemicals to conventional fungicides for the control of major postharvest diseases of stone fruit. Journal of Food Protection 72, 1037-1046.

Palou, L., Smilanick, J.L., Droby, S., 2008. Alternatives to conventional fungicides for the control of citrus postharvest green and blue moulds. Stewart Postharvest Review 4:2, 1-16.

Palou, L., Smilanick, J.L., Usall, J., Viñas, I., 2001. Control of postharvest blue and green molds of oranges by hot water, sodium carbonate, and sodium bicarbonate. Plant Disease 85, 371-376.

Palou, L., Usall, J., Muñoz, J.A., Smilanick, J.L., Viñas, I., 2002. Hot water, sodium carbonate, and sodium bicarbonate for the control of postharvest green and blue molds of clementine mandarins. Postharvest Biology and Technology 24, 93-96.

Plaza, P., Usall, J., Torres, R., Abadías, M., Smilanick, J.L., Viñas, I. 2004. The use of sodium carbonate to improve curing treatments 
against green and blue moulds on citrus fruits. Pest Management Science 60, 815-821.

Prusky, D., McEvoy, J.L., Saftner, R.A., Conway, W.S., Jones, R., 2004. Relationship between host acidification and virulence of Penicillium spp. on apple and citrus fruit. Phytopathology 94, 44-51.

Restaino, L.K., Komatsu, K., Syracuse, M.J., 1981. Effects of acids on potassium sorbate inhibition on food-related microorganisms in culture media. Journal of Food Science 47, 134-143.

Richer, D.L., 1987. Synergism - a patent view. Pesticide Science 19, 309315.

Romanazzi, G., Lichter, A., Mlikota-Gabler, F., Smilanick, J.L., 2012. Recent advances on the use of natural and safe alternatives to conventional methods to control postharvest gray mold of table grapes. Postharvest Biology and Technology 63, 141-147.

Rushing, N.B, Senn, V.J., 1963. The effect of benzoic, sorbic, and dehydroacetic acids on the growth of citrus products spoilage organisms. Proceedings of the Florida State Horticultural Society 76, 271-276.

Sánchez-Torres, P., Tuset, J.J., 2011. Molecular insights into fungicide resistance in sensitive and resistant Penicillium digitatum strains infecting citrus. Postharvest Biology and Technology 59, 159-165.

Schirra, M., D'hallewin, G., Cabras, P., Angioni, A., Garau, V.L., 1998. Seasonal susceptibility of Tarocco oranges to chilling injury as affected by hot water and thiabendazole postharvest dip treatments. Journal of Agricultural and Food Chemistry 46, 1177-1180.

Schirra, M., Cabras, P., Angioni, A., D’hallewin, G., Ruggiu, R., Minelli, E.V., 1997. Effect of heated solutions on decay control and residues of imazalil in lemons. Journal of Agricultural and Food Chemistry 45, 4127-4130.

Siegel, M.R., Ragsdale, N.N., 1978. Antifungal mode of action of imazalil. Pesticide Biochemistry and Physiology 9, 48-56.

Smilanick, J.L., Mansour, M.F., Mlikota-Gabler, F., Sorenson, D., 2008. Control of citrus postharvest green mold and sour rot by potassium sorbate combined with heat and fungicides. Postharvest Biology and Technology 47, 226-238.

Smilanick, J.L., Margosan, D.A., Mlikota-Gabler, F., Usall, J., Michael, I.F., 1999. Control of citrus green mold by carbonate and bicarbonate 
salts and the influence of commercial postharvest practices on their efficacy. Plant Disease 83, 139-145.

Smith, W.L., 1962. Chemical treatments to reduce postharvest spoilage of fruits and vegetables. The Botanical Review 28, 411-445.

Sorenson, D., Smilanick, J.L., Margosan, D.A., 1999. Postharvest high pressure washing of citrus fruit with sodium bicarbonate to control green mold. Phytopathology 89, S74.

US FDA (United States Federal Drug Administration), 2001. Direct Food Substances Affirmed as Generally Recognized as Safe. Code of Federal Regulations, Title 21 - Food and Drugs, Vol. 3, Part 184.

Van den Bossche, H., Willemsens, G., Cools, W., Lauwers, W.F.J., Le Jeune, L., 1978. Biochemical effects of miconazole on fungi. II. Inhibition of ergosterol biosynthesis in Candida albicans. ChemicoBiological Interactions 21, 59-78.

Venditti, T., Molinu, M.G., Dore, A., Agabbio, M., D’hallewin, G., 2005. Sodium carbonate treatment induces scoparone accumulation, structural changes, and alkalinization in the albedo of wounded Citrus fruits. Journal of Agricultural and Food Chemistry 53, 3510-3518.

Wang, C., Chen, Y., Xu, Y., Wu, J., Xiao, G., Zhang, Y., Liu, Z., 2012. Effect of dimethyl dicarbonate as disinfectant on the quality of freshcut carrot (Daucus carota L.). Journal of Food Processing and Preservation 37, 751-758.

Yahia, E.M. (ed.), 2011. Postharvest Biology and Technology of Tropical and Subtropical Fruits. Volume 3: Cocona to Mango. Woodhead Publishing Ltd. Cambridge, UK.

Chen, Y., Wang, H., Xu, Y., Wu, J., Xiao, G., 2013. Effect of treatment with dimethyl dicarbonate on microorganisms and quality of Chinese cabbage. Postharvest Biology and Technology 76, 139-144.

Zhang, J., Swingle, P.P., 2003. Control of green mold on Florida citrus fruit using bicarbonate salts. Proceedings of the Florida State Horticultural Society 116, 375-378.

Zhu, J., Xie, Q., Li, H., 2006. Occurrence of imazalil-resistant biotype of Penicillium digitatum in China and the resistant molecular mechanism. Journal of Zhejiang University Science A, 7 (Suppl. II), 362-365. 
Chapter 2

\title{
Evaluation of brief potassium sorbate dips to control postharvest penicillium decay on major citrus species and cultivars
}

\author{
CLARA MONTESINOS-HERRERO ${ }^{1}$, MIGUEL ÁNGEL DEL RÍO ${ }^{1}$, \\ CRISTINA PASTOR ${ }^{1}$, OSVALDO BRUNETTI ${ }^{2}$ and LLUÍS PALOU ${ }^{1}$
}

${ }^{1}$ Laboratori de Patologia, Centre de Tecnologia Postcollita (CTP) Institut Valencià d'Investigacions Agràries (IVIA) Apartat Oficial, 46113 Montcada, València, Spain ${ }^{2}$ Decco Ibérica Post Cosecha S.A.U.

C/Villa de Madrid, 54. 46988 Paterna, València, Spain

Reference: Postharvest Biology and Technology 2009, 52, 117-125. 



\begin{abstract}
Several commercially important citrus species and cultivars were artificially inoculated with Penicillium digitatum or $P$. italicum, immersed $24 \mathrm{~h}$ later for $5,15,30$, or $60 \mathrm{~s}$ in water (control) or aqueous solutions of $3 \%(\mathrm{wt} / \mathrm{vol})$ potassium sorbate $(\mathrm{PS})$ at $20,53,58,62,65$, or $68{ }^{\circ} \mathrm{C}$, depending on the experiment, rinsed with tap water, and incubated at $20{ }^{\circ} \mathrm{C}$ for $7 \mathrm{~d}$. The most effective treatments were PS applications at 62 ${ }^{\circ} \mathrm{C}$ for 30 or $60 \mathrm{~s}$, which reduced both penicillium molds by up to 20, 25, 50 , 80, or $95 \%$ on 'Clemenules' and 'Nadorcott' mandarins, 'Fino' lemons, 'Ortanique' mandarins, and 'Valencia' oranges, respectively. After $60 \mathrm{~d}$ storage at $5{ }^{\circ} \mathrm{C}$, green mold and blue mold on 'Valencia' oranges treated with PS at $62{ }^{\circ} \mathrm{C}$ for $60 \mathrm{~s}$ were reduced by 96 and $83 \%$, respectively. Treatments applied to nonwounded fruit before inoculation did not induce disease resistance. In semicommercial trials with 'Valencia' oranges, treatments with heated PS alone, PS combined with the fungicide imazalil (IZ), and IZ alone were all equally effective. On 'Marisol' clementine mandarins, the combination PS+IZ at room temperature allowed a significant reduction of the IZ doses needed for effective control of green mold.
\end{abstract}

Keywords: Penicillium digitatum, $P$. italicum, green mold, blue mold, alternatives to postharvest fungicides, GRAS compounds, integrated disease management

\title{
Introduction
}

In countries with Mediterranean climate the postharvest diseases that cause more losses are green mold, caused by Penicillium digitatum (Pers.:Fr.) Sacc., and blue mold, caused by P. italicum Wehmer (Tuset, 1987). For many years, these wound pathogens have been controlled by using synthetic fungicides like imazalil (IZ), sodium ortho-phenylphenate (SOPP), or thiabendazole (TBZ) (Eckert and Eaks, 1989; Smilanick et al., 2006). Concerns about their impact on human health and the environment (Dezman et al., 1986) and the rise of fungicide-resistant biotypes of $P$. digitatum and $P$. italicum (Bus et al., 1991; Holmes and Eckert, 1999; Kinay et al., 2007) have encouraged the development of alternatives to traditional control means. 
Post-inoculation treatments with hot water (Schirra et al., 2000; Palou et al., 2001, 2002a) or with aqueous solutions containing very low toxicity substances, generally regarded as safe (GRAS) by the United States Food and Drug Administration (US FDA) (Smilanick et al., 1999; Palou et al., 2001, 2002a), have been some of the tested alternatives. Compounds included in the GRAS classification can be used in a variety of applications with no restrictions from regulations in the European Union (EU) or the USA (Lindsay, 1996). Sodium carbonate and sodium bicarbonate are effective components of alternative strategies to replace postharvest fungicides in citrus (Smilanick et al., 1997, 1999; Palou et al., 2001, 2002a). However, disposal of used solutions is a problem due to the content of sodium and the high $\mathrm{pH}$ and conductivity of the solutions of sodium carbonates (Smilanick et al., 2008). Palou et al. (2002b) studied the antifungal activity of a wide range of food additives and GRAS substances against $P$. digitatum and $P$. italicum, and found that potassium sorbate (PS) was among the most effective on oranges and lemons.

Sorbic acid and some sorbic acid salts have been widely used for years as preservatives in processed food (Chichester and Tanner, 1972). PS $\left(\mathrm{C}_{6} \mathrm{H}_{7} \mathrm{O}_{2} \mathrm{~K}\right.$; EU E-Number list: E-202) is a wide spectrum antimicrobial food additive with effect against molds and yeasts, mostly within the $\mathrm{pH}$ range of 3 to 6.5 (Bandelin, 1958). PS is more water soluble than sorbic acid, thus it is more appropriate for application as aqueous solutions. Moreover PS has been recently classified by the United States Environmental Protection Agency as a minimal risk active ingredient and exempt from residue tolerances (US EPA, 2005).

PS has been tested alone or in combination with commercial fungicides against the major postharvest pathogens of citrus fruits. Recently, Smilanick et al. (2008) combined low concentrations of PS with IZ, TBZ, pyrimethanil (PYR), and fludioxonil (FLU), and found that PS was not only compatible with these fungicides but also improved their performance against $P$. digitatum and Geotrichum citri-aurantii, the causal pathogen of sour rot. In other studies to control either sour rot (Kitagawa and Kawada, 1984) or green mold (Smoot and McCornack, 1978; Wild, 1987; Hall, 1988; Palou et al., 2002b), PS solutions applied at room temperature or moderately heated for relatively long immersion times (2-3 min) resulted in a relatively effective control of the diseases. 
However, from a commercial point of view, shorter treatments are desirable. In order not to lose effectiveness, the use of solutions at higher temperature is likely to be needed. Several studies have already shown an improvement in effectiveness, when the treatment time was very brief, when PS solutions were heated (Wild, 1987; Smilanick et al., 2008).

Few studies have been done to elucidate the ability of GRAS compounds to induce resistance in citrus fruits; however, it has been recognized as an important and manageable form of controlling postharvest diseases (El Ghaouth, 1994; Venditti et al., 2005). It is known that the curative or preventive activity of alternative GRAS compounds in controlling postharvest diseases is more dependent on the interaction with the host than that of conventional chemical fungicides, and such interaction is highly dependent on fruit physical and physiological condition as well as on fruit species and cultivar (Palou et al., 2001, 2002a, b, 2008; Venditti et al., 2005).

The objective of this work was to assess the effectiveness of brief PS treatments at several temperatures against postharvest penicillium molds on citrus fruits. Different treatment durations and temperatures were tested on several commercially important citrus species and cultivars to elucidate which conditions were more effective in each case. Individual influence of treatment temperature and length on the efficacy of the treatments was also studied. Treatments were tested for both disease control ability and induction of disease resistance in the fruit. In some cases, the effectiveness of PS treatments was also evaluated during longterm cold storage. Both laboratory and semicommercial experiments were conducted. In semicommercial experiments, the effect of PS treatments was compared to that of low doses of the conventional fungicide IZ, and the effect of combination of low doses of PS and IZ was also assessed.

\section{Materials and methods}

\section{Fruit}

Fruit used in the experiments were 'Valencia' oranges (Citrus sinensis (L.) Osbeck), 'Fino' lemons (C. limon (L.) Burm.), 'Marisol' and 'Clemenules' (synonyms: 'Nules', 'Clementina de Nules') clementine mandarins $(C$. reticulata Blanco), or 'Ortanique' $[C$. reticulata $\mathrm{x}(C$. 
sinensis x $C$. reticulata); synonym: 'Topaz'] and 'Nadorcott' $(C$. reticulata x $C$. sinensis; synonyms: 'Afourer', 'W. Murcott') hybrid mandarins. Fruit were collected from commercial orchards in València province (Spain) and stored at $5^{\circ} \mathrm{C}$ and $90 \%$ relative humidity (RH) up to 2 weeks. Fruits used in the study were free from previous postharvest treatments or coating. Before each treatment, fruit were selected, randomized, rinsed with tap water, and let to air-dry at room temperature.

\section{Fungal inoculum}

The strains of $P$. digitatum (NAV-7) and $P$. italicum (MAV-1) were isolated from decayed oranges or mandarins collected in orchards in the province of València. These fungi were cultivated, re-cultured from single conidia, identified, selected for their virulence, and included in the fungal culture collection of the Centre de Tecnologia Postcollita of the IVIA. Fungi were multiplied by inoculation of conidia in $90 \mathrm{~mm}$ petri dishes of potato dextrose agar (PDA) and incubation at $25^{\circ} \mathrm{C}$ for 7 to 14 d. For each pathogen, a quantity of conidia was taken from the mycelium surface and suspended in a sterile aqueous solution of $0.05 \%$ (wt/vol) Tween 80 . The conidial suspension was filtered to separate conidia from parts of mycelium and conidial concentration was determined using a haemocytometer. The suspension of conidia was diluted with sterile distilled water to a final concentration of $10^{9}$ conidia $\mathrm{L}^{-1}$. This is the concentration of conidia recommended in the evaluation of postharvest treatments for the control of green and blue molds (Eckert and Brown, 1986). The tip of a stainless steel rod, $1 \mathrm{~mm}$ wide and $2 \mathrm{~mm}$ in length, was immersed in a conidial suspension of the corresponding pathogen and inserted in the fruit rind afterwards. Fruit was inoculated in two opposite points in the equatorial zone, one with $P$. digitatum and the opposite with $P$. italicum. Inoculated fruit was maintained at $20^{\circ} \mathrm{C}$ until treatment, $24 \mathrm{~h}$ later. When the potential induction of resistance was tested, the fruit was treated, held for 1,2 or $5 \mathrm{~d}$ at $20^{\circ} \mathrm{C}$, and then inoculated following the above mentioned procedure but using a suspension of pathogenic fungi of $10^{8}$ conidia $\mathrm{L}^{-1}$.

\section{Laboratory experiments for assessment of disease control ability}

Stainless steel buckets containing $10 \mathrm{~L}$ of $3 \%$ (wt/vol) PS (Guinama S.L., Alboraia, València, Spain) in deionized water were used in all tests. 
The solutions were kept at the natural $\mathrm{pH}$ of 7.8. When needed, solutions were heated by placing the buckets in a 250-L stainless steel water tank fitted with two electrical resistances ( $4.5 \mathrm{~kW}$ each), a thermostat, and an automatic water-recirculating system. Fruit were placed into $18 \mathrm{~L}$ multiperforated-wall stainless steel containers, exactly fitting in the abovementioned buckets, and completely immersed in the treatment solution. Control fruit were dipped in water alone at $20^{\circ} \mathrm{C}$. The tested citrus cultivars, treatment conditions, and incubation/cold storage conditions for this set of laboratory experiments are summarized in Table 1. After treatment, PS-treated fruit was rinsed with low-pressure tap water for $5 \mathrm{~s}$ running 20-30 $\mathrm{cm}$ above the fruit, left to air-dry and placed in plastic cavity sockets on cardboard trays. For each treatment, 3 replicates of 25 fruit each were used. Treated fruit were incubated in walk-in chambers at $20{ }^{\circ} \mathrm{C}$ and $90 \% \mathrm{RH}$ for 7 or $14 \mathrm{~d}$ or, in some experiments, stored at $5{ }^{\circ} \mathrm{C}$ for $60 \mathrm{~d}$. Disease incidence was counted every $7 \mathrm{~d}$ as the number of decayed fruit. Three days after treatment, fruit were inspected for potential rind injures caused by the treatments. All the experiments were conducted twice.

\begin{tabular}{|c|c|c|c|c|c|}
\hline \multirow[t]{2}{*}{ Fruit } & \multicolumn{3}{|c|}{ Treatments } & \multicolumn{2}{|c|}{ Incubation/storage } \\
\hline & Substance & $\mathbf{T}\left({ }^{\circ} \mathbf{C}\right)$ & $\begin{array}{c}\text { Time } \\
(\mathrm{s})\end{array}$ & $\mathbf{T}\left({ }^{\circ} \mathrm{C}\right)$ & $\begin{array}{c}\text { Time } \\
\text { (d) }\end{array}$ \\
\hline \multirow{6}{*}{$\begin{array}{l}\text { 'Valencia' } \\
\text { oranges }\end{array}$} & Water & $20,62,65,68$ & 5 & 20 & 7 \\
\hline & PS & $20,62,65,68$ & 5 & 20 & 7 \\
\hline & Water & $20,53,58,62$ & 15,30 & 20 & 7 \\
\hline & PS & $20,53,58,62$ & 15,30 & 20 & 7 \\
\hline & Water & 20 & 60 & 20 & 14 \\
\hline & PS & 62 & 60 & 5 & 60 \\
\hline \multirow[t]{2}{*}{ 'Fino' lemons } & Water & 20 & 15,30 & 20 & 7 \\
\hline & PS & 20,62 & 15,30 & 20 & 7 \\
\hline \multirow{2}{*}{$\begin{array}{l}\text { 'Clemenules' } \\
\text { mandarins }\end{array}$} & Water & $20,53,58,62$ & 60 & 20 & 7 \\
\hline & PS & $20,53,58,62$ & 60 & 20 & 7 \\
\hline \multirow{2}{*}{$\begin{array}{l}\text { 'Nadorcott' } \\
\text { mandarins }\end{array}$} & Water & 20 & 30 & 20 & 7 \\
\hline & PS & $20,53,58,62$ & 30 & 20 & 7 \\
\hline \multirow{2}{*}{$\begin{array}{l}\text { 'Ortanique' } \\
\text { mandarins }\end{array}$} & Water & 20,62 & 60 & 20 & 14 \\
\hline & PS & 20,62 & 60 & 5 & 60 \\
\hline
\end{tabular}

Table 1. Summary of treatments applied in laboratory experiments. 


\section{Laboratory experiments for assessment of induced resistance}

Following the same procedure of disease control tests previously mentioned, 'Valencia' oranges or 'Ortanique' mandarins were treated with deionized water at $20{ }^{\circ} \mathrm{C}$ (control) or aqueous solutions of $3 \%$ (wt/vol) PS at $62{ }^{\circ} \mathrm{C}$ for $60 \mathrm{~s}$ and then held for 1,2 , or $5 \mathrm{~d}$ at $20^{\circ} \mathrm{C}$. After each one of these time periods, fruit were inoculated at two opposite points of the equatorial zone with a suspension of $10^{8}$ conidia $\mathrm{L}^{-1}$ of $P$. digitatum. After inoculation, fruit were incubated at $20{ }^{\circ} \mathrm{C}$ and the number of infected lesions and the diameter of each lesion (disease severity) was measured after 3 and $7 \mathrm{~d}$ of incubation.

\section{Semicommercial experiments}

'Valencia' oranges were commercially harvested and transported to our laboratory where they were selected, randomized, and inoculated with $P$. digitatum and $P$. italicum as described above. One day after inoculation, fruit were transported to the facilities of the company Decco Ibérica Post Cosecha S.A.U. in Paterna (València), where treatments were applied using a 125-L stainless steel tank with an automatic heating system and thermostat. Treatments consisted of $30 \mathrm{~s}$ dips in water at $20^{\circ} \mathrm{C}$ (control), 1 $\%$ (wt/vol) PS (Nantong Acetic Acid Chemical Co Ltd., Tangzha, Nantong City, Jiangshu Province, China), $0.05 \mathrm{~mL} \mathrm{~L}^{-1}$ a.i. IZ EC (imazalil emulsifiable concentrate, Deccozil $50^{\circledR}$, Decco Ibérica Post Cosecha S.A.U., Paterna, València, Spain), and a mixture of a final concentration of $1 \%$ PS and $0.05 \mathrm{~mL} \mathrm{~L}^{-1}$ a.i. IZ EC (Deccozil 50 ${ }^{\circledR}$ ). PS, $\mathrm{IZ}$, and mixture solutions were heated to $45^{\circ} \mathrm{C}$. Treated fruit were not rinsed with tap water. For each one of these four treatments, 3 replicates consisting of $20 \mathrm{~kg}$ plastic boxes each were used (about 80-90 oranges per box; 240-270 oranges per treatment). Treated fruit were left to air-dry and then taken back to the IVIA where they were incubated at $20{ }^{\circ} \mathrm{C}$ and $90 \% \mathrm{RH}$. After $2 \mathrm{~d}$, the rind of the fruit was observed to check for any treatment-induced damage. Disease incidence was assessed after 7 and $14 \mathrm{~d}$ of incubation.

'Marisol' clementine mandarins were collected from a commercial orchard and brought to a local packinghouse in Bétera (València) where they were checked for injuries, selected, and randomized. Fruit were not artificially inoculated in this trial (natural infection). Tested solutions were water alone (control), 2\% (wt/vol) PS (Nantong Acetic Acid 
Chemical Co Ltd.), $525 \mathrm{mg} \mathrm{L}^{-1}$ a.i. IZ (imazalil sulfate, Deccozil S-7.5 ${ }^{\circledR}$, Decco Ibérica Post Cosecha S.A.U.), and a mixture of PS and IZ at a final concentration of $1 \%$ (wt/vol) PS and $0.2 \mathrm{~mL} \mathrm{~L}^{-1}$ a.i. IZ EC $\left(\right.$ Deccozil $\left.50^{\circledR}\right)$. All treatments were applied at room temperature $(19 \pm$ $2^{\circ} \mathrm{C}$ ) for $30 \mathrm{~s}$. Twelve $20-\mathrm{kg}$ field boxes containing an average of 222 mandarins each were used for each treatment (average of 2,664 fruit per treatment). Solutions were renewed after treating six boxes. Nonrinsed treated fruit were degreened in a commercial degreening room with 1-2 $\mu \mathrm{L} \mathrm{L}^{-1}$ ethylene at atmospheric pressure and 19 to $21^{\circ} \mathrm{C}$ for $4 \mathrm{~d}$. Once degreened, the fruit were transported to the IVIA and kept in a chamber at $20{ }^{\circ} \mathrm{C}$ and $90 \% \mathrm{RH}$. Decay incidence was assessed 9, 20 and $30 \mathrm{~d}$ after the application of the treatments.

\section{Statistical analysis}

The experiments were designed to sequentially determine effective PS treatment conditions for each of the different tested citrus species and cultivars, not to establish general effects of quantitative variables such as treatment temperature or time on disease incidence. Therefore, the independent variables in each test were considered as qualitative variables. Values recording percentage of disease incidence were arcsinetransformed and two- or three-way analyses of variance (ANOVA) were performed using Statgraphics Plus 4.1 (Manugistics Inc., Rockville, Maryland, USA). Since differences between experiments were not significant, presented means for laboratory tests are average values from two experiments. Means were separated by Fisher's Protected Least Significant Difference (LSD) test $(P \leq 0.05)$. Values shown are nontransformed data.

\section{Results}

\section{Laboratory experiments to assess disease control}

On 'Nadorcott' mandarins, the incidence of green and blue molds on fruit treated with PS at the highest tested temperatures was significantly lower than that on control fruit (water at $20{ }^{\circ} \mathrm{C}$ for $30 \mathrm{~s}$ ). However, the magnitude of the reduction was small (up to $25 \%$ in the case of green mold; Fig. 1). On 'Clemenules' clementine mandarins, although treatment time was increased to $60 \mathrm{~s}$, none of the tested treatments was effective against green and blue molds (Fig. 1). 


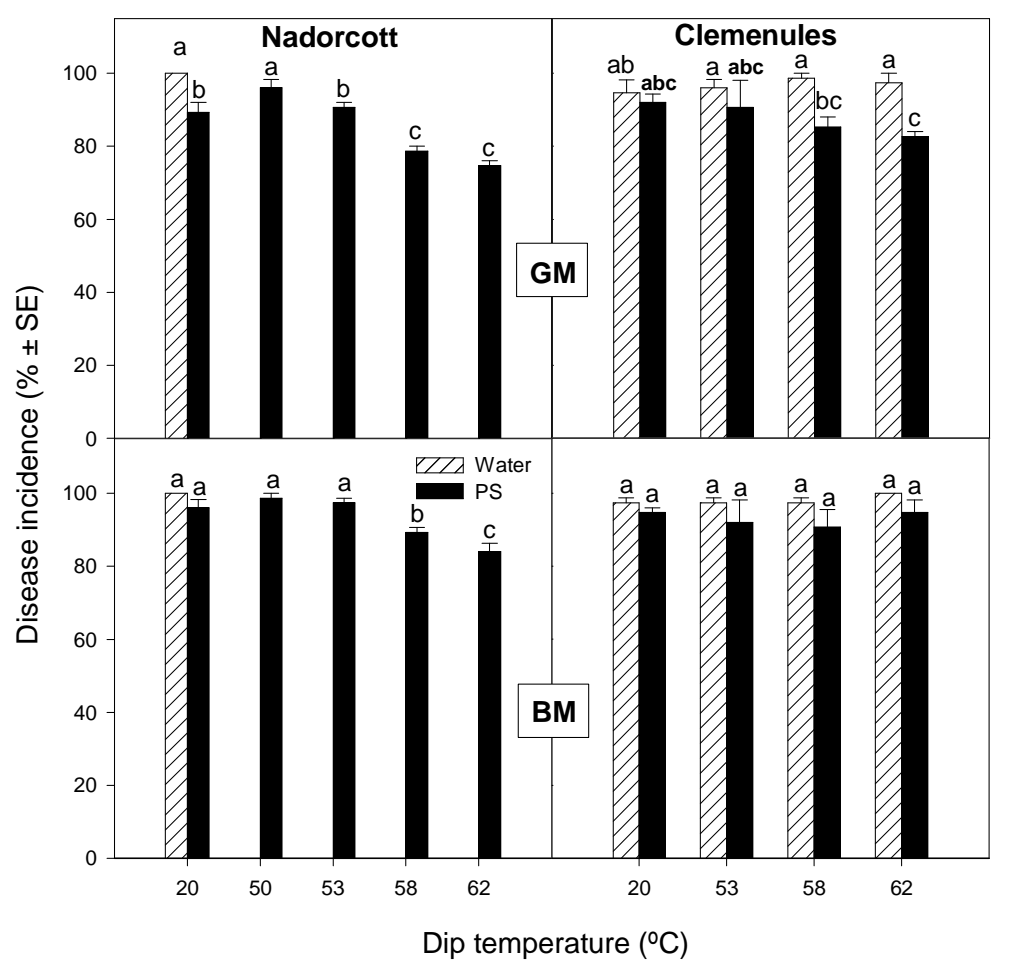

Fig. 1. Incidence of green $(\mathrm{GM})$ and blue $(\mathrm{BM})$ molds on mandarins artificially inoculated, dipped $24 \mathrm{~h}$ later in water or $3 \%(\mathrm{wt} / \mathrm{vol})$ potassium sorbate (PS) and incubated for $7 \mathrm{~d}$ at $20{ }^{\circ} \mathrm{C}$ and $90 \% \mathrm{RH}$. 'Nadorcott' and 'Clemenules' mandarins were treated for 30 and $60 \mathrm{~s}$, respectively. Water treatments on 'Nadorcott' mandarins were only at $20^{\circ} \mathrm{C}$. For each disease and cultivar, columns with unlike letters are significantly different according to Fisher's Protected LSD test $(P \leq 0.05)$ applied to arcsine-transformed data. Nontransformed means \pm standard error (SE) are shown.

In contrast, on 'Ortanique' mandarins, PS treatments at $62{ }^{\circ} \mathrm{C}$ for $60 \mathrm{~s}$ reduced the incidence of green and blue molds with respect to control fruit (treated with water at $20{ }^{\circ} \mathrm{C}$ for $60 \mathrm{~s}$ ) by 86 and $65 \%$, respectively, after incubation at $20{ }^{\circ} \mathrm{C}$ for $7 \mathrm{~d}$. PS treatments at $20{ }^{\circ} \mathrm{C}$ and water treatments at $62{ }^{\circ} \mathrm{C}$ scarcely reduced decay incidence on these trials (Fig. 2). When stored at $5{ }^{\circ} \mathrm{C}$ for $15 \mathrm{~d}$, green and blue mold incidence on 'Ortanique' mandarins treated with PS was 92 and $97 \%$ lower than on 
control fruit, respectively. However, control of both diseases was transitory and these reductions gradually decreased to only 36 and $10 \%$ after $60 \mathrm{~d}$ storage (Fig. 3). No peel injures caused by the treatments were observed.

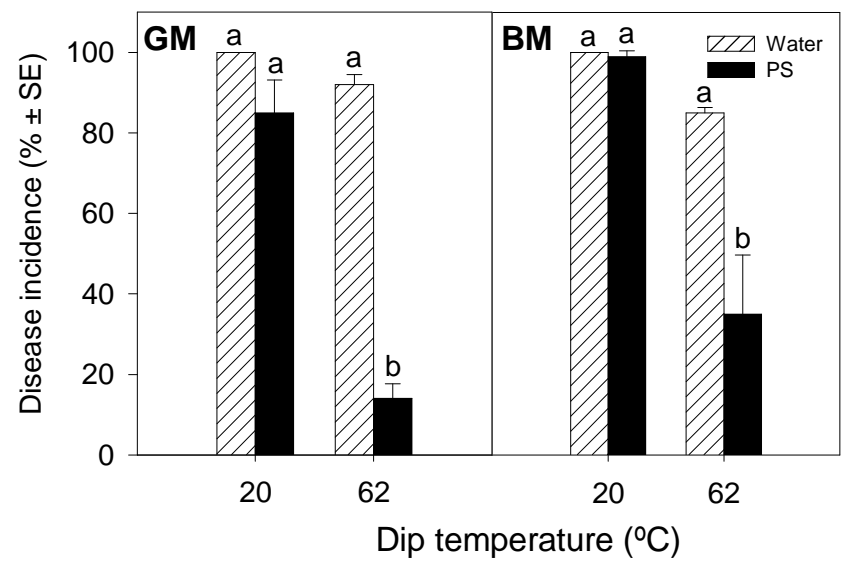

Fig. 2. Incidence of green (GM) and blue (BM) molds on 'Ortanique' mandarins artificially inoculated, dipped $24 \mathrm{~h}$ later in water or aqueous solutions of $3 \%\left(\mathrm{wt} / \mathrm{vol}\right.$ ) potassium sorbate (PS) at 20 or $62{ }^{\circ} \mathrm{C}$ for $60 \mathrm{~s}$, and incubated for $7 \mathrm{~d}$ at $20{ }^{\circ} \mathrm{C}$ and $90 \% \mathrm{RH}$. For each disease, columns with unlike letters are significantly different according to Fisher's Protected LSD test $(P \leq 0.05)$ applied to arcsine-transformed data. Nontransformed means \pm standard error (SE) are shown.

On 'Fino' lemons, the interaction between dip time and treatment (water or PS at 20 or $62{ }^{\circ} \mathrm{C}$ ) was significant. Treatments with PS at $62{ }^{\circ} \mathrm{C}$ slightly controlled both green and blue molds. Average decay incidence after treatments with PS at $62{ }^{\circ} \mathrm{C}$ for $15 \mathrm{~s}$ was 30 and $40 \%$ lower than that recorded on control lemons for $P$. digitatum and $P$. italicum, respectively (Fig. 4). When treatment duration was increased to $30 \mathrm{~s}$, green mold and blue mold were reduced by 45 and $55 \%$, respectively.

Treatments at lower temperatures were less effective. The rind of the lemons was not damaged by any treatment.Combined effects of the type 
of substance (PS or water), treatment temperature, and dip duration (5, 15 , or $30 \mathrm{~s}$ ) were evaluated on 'Valencia' oranges. Blue mold incidence on fruit dipped for $5 \mathrm{~s}$ in PS was about $50 \%$ lower than after treatments with water at the same temperature, and 70 and $90 \%$ lower on fruit dipped for 15 and $30 \mathrm{~s}$, respectively (Fig. 5). A similar trend was observed for green mold, although the differences between 15 and $30 \mathrm{~s}$ treatments were small. On 'Valencia' oranges, temperature had greater influence on the efficacy of water treatments than on that of PS treatments. Control of both diseases by 5 or $15 \mathrm{~s}$ immersions in water was not improved by increasing the temperature of the treatments. Only treatments with water for $30 \mathrm{~s}$ were more effective when applied at higher temperatures (Fig. 5). Generally, treatments for 5, 15, or $30 \mathrm{~s}$ were slightly more effective against $P$. italicum than against $P$. digitatum. Green mold incidence was $90 \%$ on control fruit and $10 \%$ on fruit treated with PS at $62{ }^{\circ} \mathrm{C}$ for $15 \mathrm{~s}$ (89\% incidence reduction). Blue mold incidence was $78 \%$ on control fruit while it was absent or very low (1.6 $\%)$ on fruit treated with PS for $30 \mathrm{~s}$ at any of the tested temperatures (98 $\%$ incidence reduction) (Fig. 5). None of the treatments caused visible injuries to the rind of the oranges.

PS treatments at $62{ }^{\circ} \mathrm{C}$ for $60 \mathrm{~s}$ were further tested on 'Valencia' oranges that were evaluated after 7 and $14 \mathrm{~d}$ of incubation at $20^{\circ} \mathrm{C}$. While the incidence of decay caused by both $P$. digitatum and $P$. italicum after $7 \mathrm{~d}$ was $100 \%$ on control fruit, it was 2.6 and $5.3 \%$ on treated fruit, respectively. After $14 \mathrm{~d}$, the incidence of both molds on treated fruit increased to $12 \%$ (Fig. 6). The same PS treatment reduced both penicillium molds by more than $98 \%$ on fruit stored at $5{ }^{\circ} \mathrm{C}$ for $15 \mathrm{~d}$. After a cold storage period of $60 \mathrm{~d}$, reduction of green and blue molds on PS-treated fruit was 96 and $83 \%$, respectively (Fig. 3). No damage was observed in the skin of the oranges. 


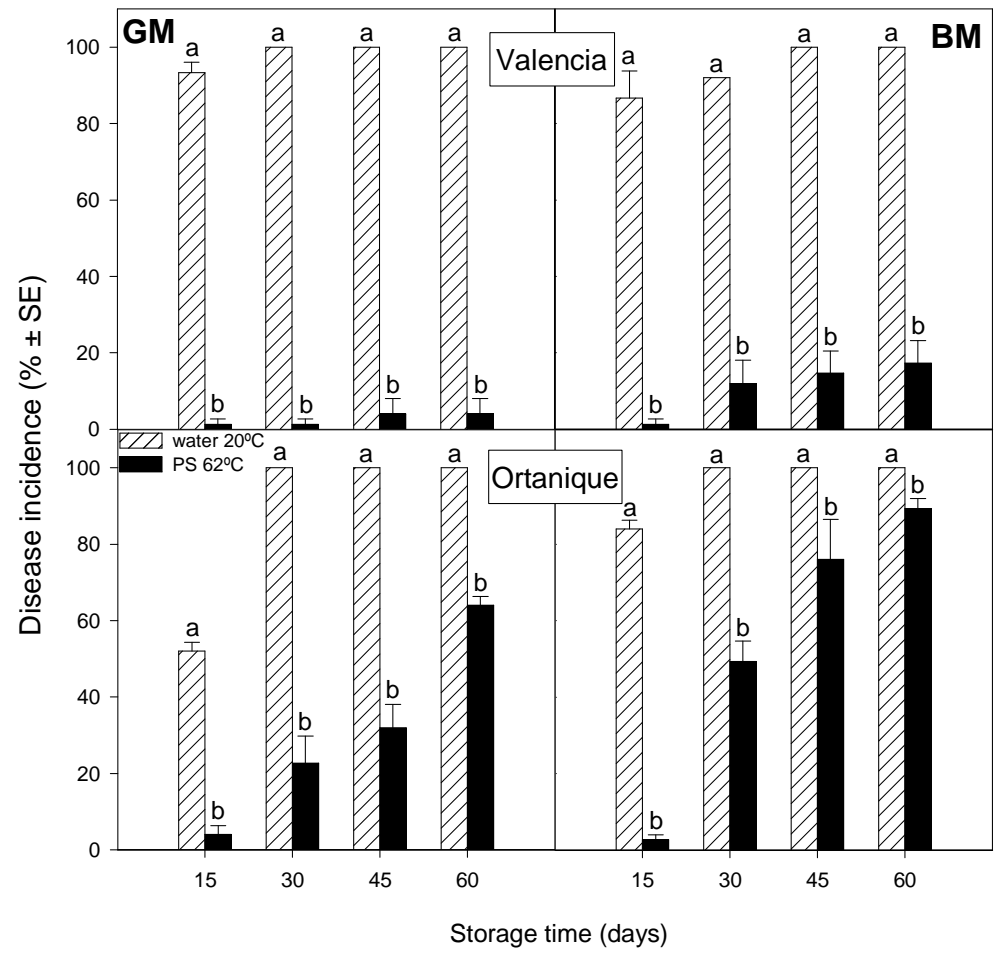

Fig. 3. Incidence of green (GM) and blue (BM) molds on 'Valencia' oranges and 'Ortanique' mandarins artificially inoculated, dipped $24 \mathrm{~h}$ later in water at $20{ }^{\circ} \mathrm{C}$ or aqueous solutions of $3 \%(\mathrm{wt} / \mathrm{vol})$ potassium sorbate (PS) at $62{ }^{\circ} \mathrm{C}$ for $60 \mathrm{~s}$, and stored for $60 \mathrm{~d}$ at $5{ }^{\circ} \mathrm{C}$ and $90 \% \mathrm{RH}$. For each disease and cultivar, columns with unlike letters are significantly different according to Fisher's Protected LSD test $(P \leq 0.05)$ applied to arcsine-transformed data. Nontransformed means \pm standard error (SE) are shown. 


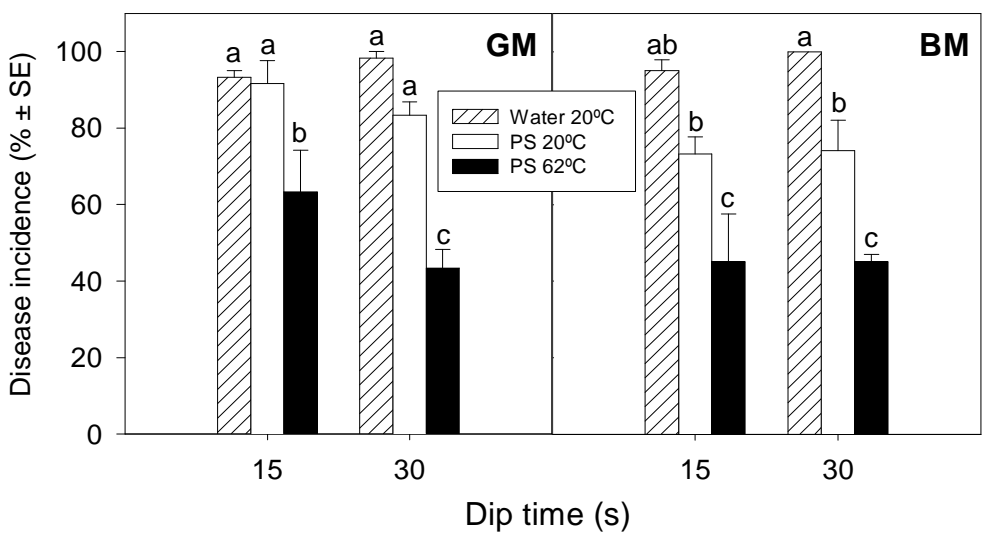

Fig. 4. Incidence of green (GM) and blue (BM) molds on 'Fino' lemons artificially inoculated, dipped $24 \mathrm{~h}$ later in water at $20^{\circ} \mathrm{C}$ or aqueous solutions of $3 \%(\mathrm{wt} / \mathrm{vol})$ potassium sorbate (PS) at 20 or $62{ }^{\circ} \mathrm{C}$ for 15 or $30 \mathrm{~s}$, and incubated for $7 \mathrm{~d}$ at $20^{\circ} \mathrm{C}$ and $90 \% \mathrm{RH}$. For each disease, columns with unlike letters are significantly different according to Fisher's Protected LSD test $(P \leq$ $0.05)$ applied to arcsine-transformed data. Nontransformed means \pm standard error (SE) are shown.

\section{Laboratory experiments to assess induced resistance}

Treatments with aqueous solutions of $3 \%$ PS prior to artificial fungal inoculation did not significantly affect the severity of the lesions caused by $P$. digitatum or $P$. italicum on 'Ortanique' mandarins and 'Valencia' oranges (data not shown).

\section{Semicommercial experiments}

After $7 \mathrm{~d}$ incubation at $20^{\circ} \mathrm{C}$, the incidence of green and blue molds on artificially inoculated 'Valencia' oranges treated with water (control) was 77 and $44 \%$, respectively. The incidence of both molds on fruit treated with PS was reduced by approximately 95\%, with no significant differences between treatments. There was only a minor increase on fruit decay at $14 \mathrm{~d}$ of incubation. The high effectiveness of PS or IZ treatments when applied alone did not allow observing any possible synergistic effect of the combined treatment (Fig. 7). No rind damage was observed after any treatment. 
Chapter 2

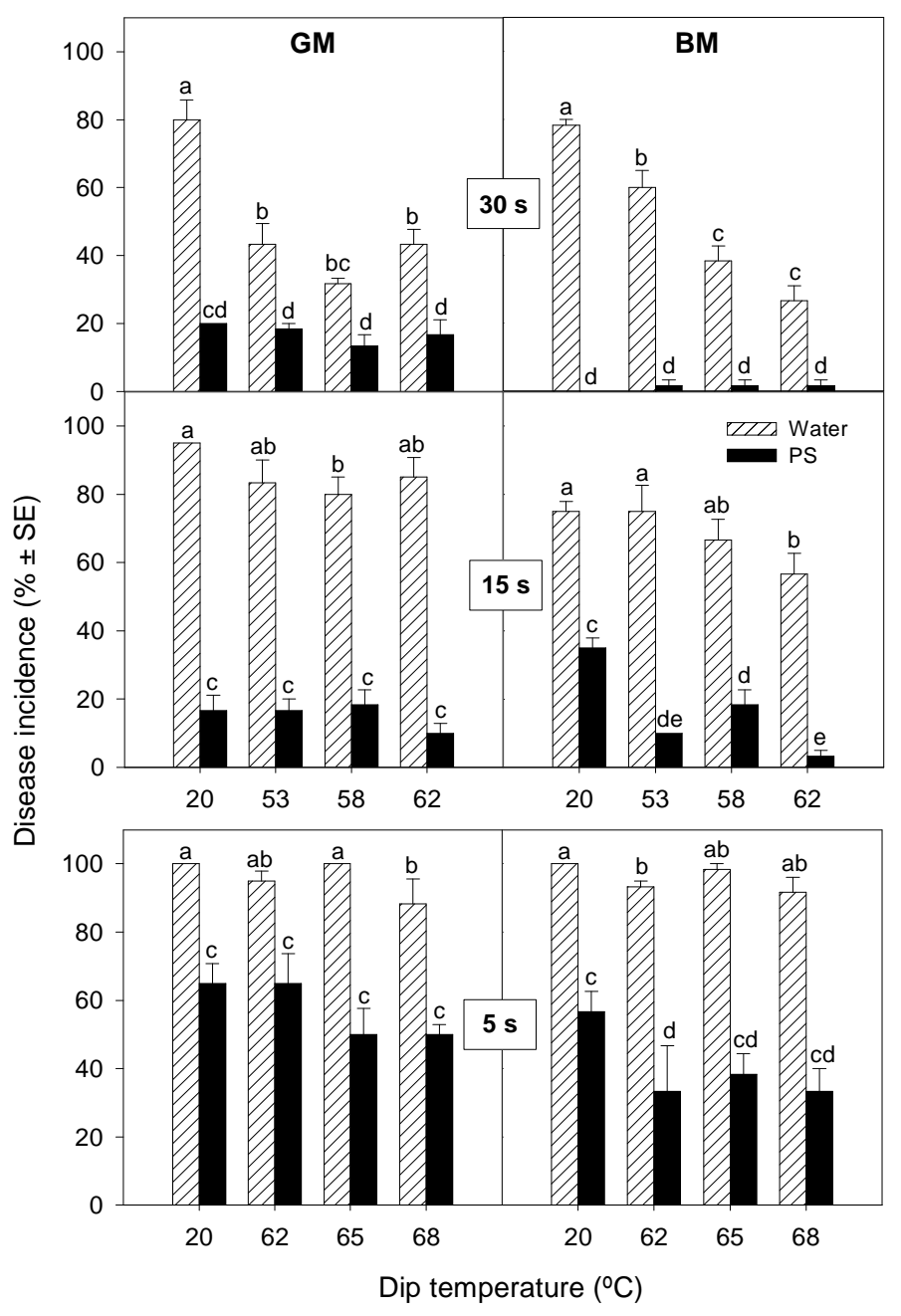

Fig. 5. Incidence of green (GM) and blue (BM) molds on 'Valencia' oranges artificially inoculated, dipped $24 \mathrm{~h}$ later in water or aqueous solutions of $3 \%$ (wt/vol) potassium sorbate (PS) at different temperatures for 5,15 , or $30 \mathrm{~s}$, and incubated for $7 \mathrm{~d}$ at $20{ }^{\circ} \mathrm{C}$ and $90 \% \mathrm{RH}$. For each disease and treatment time, columns with unlike letters are significantly different according to Fisher's Protected LSD test $(P \leq 0.05)$ applied to arcsine-transformed data. Nontransformed means \pm standard error (SE) are shown. 


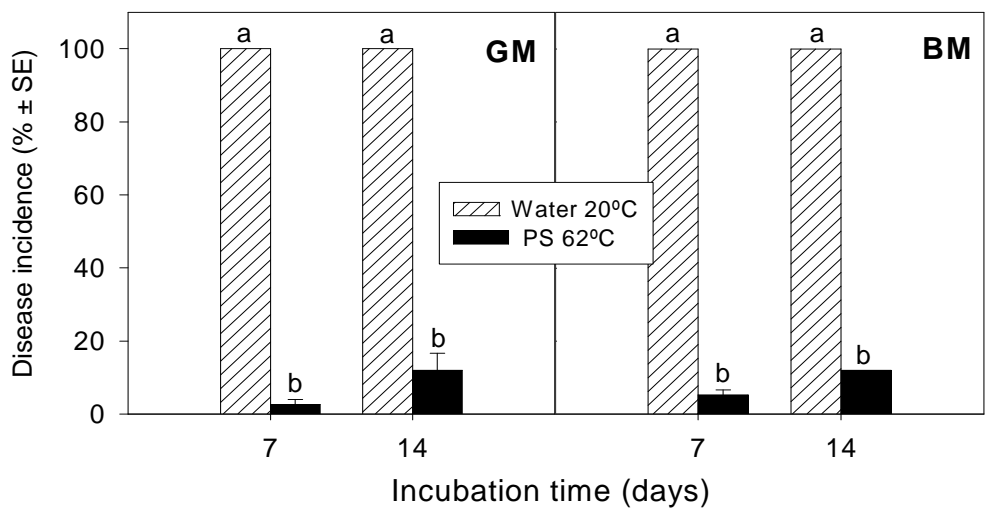

Fig. 6. Incidence of green (GM) and blue (BM) molds on 'Valencia' oranges artificially inoculated, dipped $24 \mathrm{~h}$ later in water at $20{ }^{\circ} \mathrm{C}$ or aqueous solutions of $3 \%\left(\mathrm{wt} / \mathrm{vol}\right.$ ) potassium sorbate (PS) at $62{ }^{\circ} \mathrm{C}$ for $60 \mathrm{~s}$, and incubated for $14 \mathrm{~d}$ at $20{ }^{\circ} \mathrm{C}$ and $90 \% \mathrm{RH}$. For each disease, columns with unlike letters are significantly different according to Fisher's Protected LSD test $(P \leq 0.05)$ applied to arcsine-transformed data. Nontransformed means \pm standard error (SE) are shown.

Decay on naturally infected 'Marisol' mandarins after $30 \mathrm{~d}$ incubation period at $20^{\circ} \mathrm{C}$ reached $41 \%$ of nontreated (control) fruit and was mainly caused by Penicillium spp. (62\% of rotten fruit). Other pathogens causing decay were Colletotrichum gloeosporioides, Alternaria citri, Geotrichum citri-aurantii, or Phytophtora citrophthora (data not shown). The incidence of green mold was about eight times higher (25\% of total control fruit) than that of blue mold (3.2\% of total control fruit). Mandarins infected with $P$. digitatum were $18,0.8$, and $0.7 \%$ on fruit treated with PS, PS+IZ, and IZ, respectively (Fig. 8). 
Chapter 2

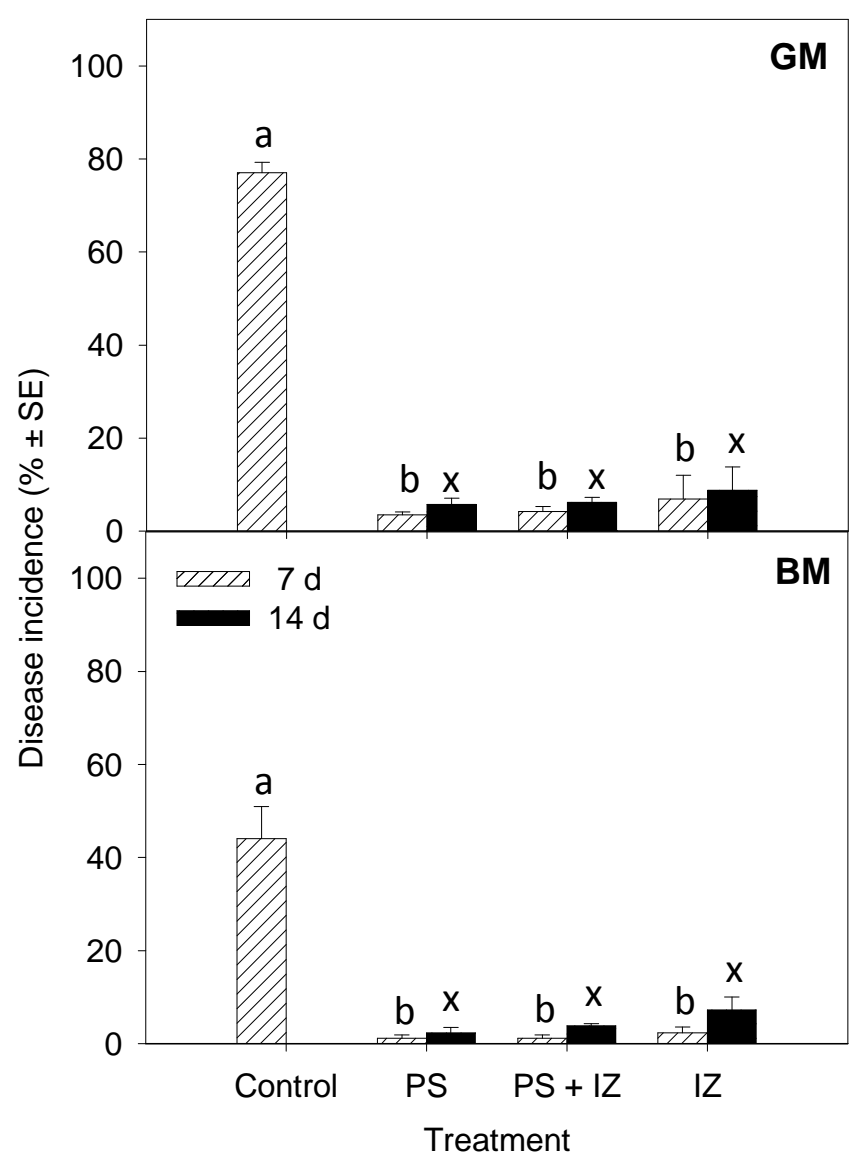

Fig. 7. Incidence of green (GM) and blue (BM) molds on artificially inoculated 'Valencia' oranges after $30 \mathrm{~s}$ dips in water at $20^{\circ} \mathrm{C}$ (control) or aqueous solutions at $45^{\circ} \mathrm{C}$ of $1 \%$ (wt/vol) potassium sorbate (PS), $0.05 \mathrm{~mL} \mathrm{~L}^{-1}$ imazalil EC (IZ), or a mixture of $1 \%$ (wt/vol) potassium sorbate and $0.05 \mathrm{~mL} \mathrm{~L}^{-1}$ imazalil EC (PS + IZ), and incubated for 7 or $14 \mathrm{~d}$ at $20^{\circ} \mathrm{C}$ and $90 \% \mathrm{RH}$. For each disease and incubation time, values with unlike letters ('a-b' for $7 \mathrm{~d}$ and ' $\mathrm{x}$ ' for $14 \mathrm{~d}$ ) are significantly different according to Fisher's Protected LSD test $(P \leq 0.05)$ applied to arcsine-transformed data. Nontransformed means \pm standard error (SE) are shown. 


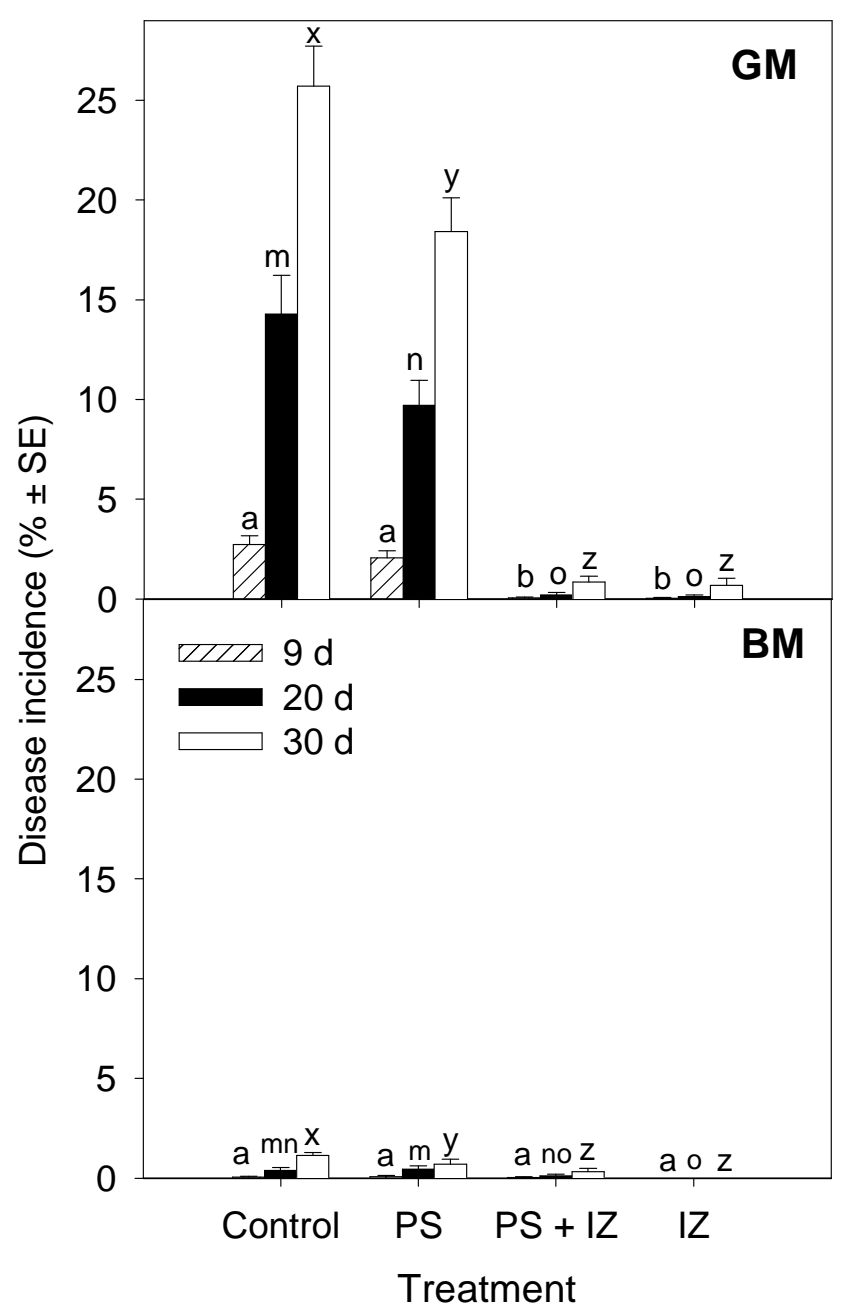

Fig. 8. Incidence of green (GM) and blue (BM) molds on naturally infected mandarins cv. Marisol after $30 \mathrm{~s}$ dips at $19^{\circ} \mathrm{C}$ in water (control) or aqueous solutions of $2 \%$ (wt/vol) potassium sorbate (PS), $525 \mathrm{mg} \mathrm{L}^{-1}$ imazalil sulfate (IZ), or a mixture of $1 \%(\mathrm{wt} / \mathrm{vol})$ potassium sorbate and $0.2 \mathrm{~mL} \mathrm{~L}^{-1}$ imazalil EC (PS + IZ), and incubated for 9,20 , or $30 \mathrm{~d}$ at $20^{\circ} \mathrm{C}$ and $90 \% \mathrm{RH}$. For each disease and incubation time, values with unlike letters ('a-b' for $9 \mathrm{~d}$, ' $\mathrm{m}$-o' for $20 \mathrm{~d}$, and ' $\mathrm{x}-\mathrm{z}$ ' for $30 \mathrm{~d}$ ) are significantly different according to Fisher's Protected LSD test $(P \leq 0.05)$ applied to arcsine-transformed data. Nontransformed means \pm standard error (SE) are shown. 


\section{Discussion}

Citrus green and blue molds were controlled effectively in some tests by short treatments with heated PS aqueous solutions. According to previous results (Palou et al., 2002b), a concentration of 3\% (wt/vol) PS was selected to be used in every test. The efficacy of the treatments depended on the one hand on the fruit species and cultivar and on the other hand on treatment temperature and duration. Combined effects of the type of substance (PS or water), treatment temperature, and dip duration $(5,15$, or $30 \mathrm{~s}$ ) were evaluated on 'Valencia' oranges. All three factors were found to significantly influence the control of both green and blue molds. Irrespective of treatment temperature and length, oranges that had been treated with PS developed much less decay than oranges that had been treated with water. Prolonging the treatment from 5 to $30 \mathrm{~s}$ greatly reduced the percentage of decayed fruit, in spite of the higher temperatures used for the $5 \mathrm{~s}$ treatments $\left(68 \mathrm{vs} .62^{\circ} \mathrm{C}\right)$. In general, the difference in decay control effectiveness between water and PS treatments increased as treatment time was prolonged. In most of the experiments, treatments with hot water alone at the same temperatures were used to assess the effects of PS and heat on disease control separately. In agreement with numerous previous reports (Schirra et al., 2000; Porat et al., 2000, 2002; Palou et al., 2001, 2002a), hot water treatments were only slightly effective against both molds and their efficacy improved as the temperature of the water increased. Heated water may cause a decreased elongation of fungal germination tubes or even a complete destruction of the germinating conidia, resulting in a reduced volume of effective fungal inoculum (Schirra et al., 2000). Treatments with PS aqueous solutions were always more effective than treatments with water alone at the same temperature and dip duration and, in some cases, PS treatments satisfactorily controlled green and blue molds. When PS is used, the undissociated acid (to which the cytoplasmic membranes of many microorganisms are permeable) diffuses into the cell until the concentration inside and outside is balanced. Sorbic acid seems to inhibit several enzymes (fumarase, espartase and succinic dehydrogenase) involved in microorganisms growth (York and Vaughn, 1964). Previous studies have shown the antifungal properties of PS against $P$. digitatum or $P$. italicum and/or the effect of heat on enhancing the efficacy of PS solutions (Smoot and 
McCornack, 1978; Wild, 1987; Hall, 1988; Palou et al., 2002b; Smilanick et al., 2008).

In the present study, very brief treatments were evaluated with a variety of citrus species and cultivars. In general, PS effectiveness after treatments at $62{ }^{\circ} \mathrm{C}$ for 15 to $30 \mathrm{~s}$ was comparable to that observed in previous studies where longer treatments (120 to $180 \mathrm{~s})$ at lower temperatures were employed (Smoot and McCornack, 1978; Wild, 1987; Hall, 1988; Palou et al., 2002b). Similar results were obtained when brief dips with heated solutions of sodium carbonates were evaluated (Montesinos-Herrero et al., 2007). Furthermore, similar temperature and treatment time combinations were also selected by Porat et al. (2000) and Smilanick et al. (2003) as the optimum conditions for effective control of green mold on fruit sprayed or drenched with hot water over rotating brushes. Temperatures used in the present study were as high as $62{ }^{\circ} \mathrm{C}$ for $60 \mathrm{~s}$ treatments or $68{ }^{\circ} \mathrm{C}$ for $5 \mathrm{~s}$ treatments. These temperatures were regarded as phytotoxic in some studies in which the length of treatment was about $150 \mathrm{~s}$ (Palou et al., 2001; Smilanick et al., 2003). In this work, however, these high temperatures did not damage the rind of treated fruit, probably due to the brief exposure time and the tap water rinse that followed PS dips and instantaneously lowered the temperature of the fruit. On the other hand, immediate rinsing of treated fruit may have reduced PS effectiveness in some tests reported herein compared to similar works with nonrinsed citrus fruit (Smilanick et al., 2008). Similarly, rinsing of clementines treated with other GRAS salts such as sodium carbonate resulted in a significant loss of treatment effectiveness against green mold (Larrigaudière et al., 2002; Palou et al., 2007). Nevertheless, we decided to rinse the fruit after PS treatment in order to simulate a hypothetical commercial application in which rinsing would be necessary to minimize the risk of injury to the fruit. Although the risk of PS injury to citrus fruit has not been rigorously evaluated, research work with sodium carbonate showed that rinsing the fruit after treatment was an effective method to avoid treatment negative effects (loss of weight and firmness during cold storage) on the quality of clementine mandarins (Larrigaudière et al., 2002).

The effectiveness of PS treatments was greatly influenced by citrus species and cultivar. On 'Nadorcott' and 'Clemenules' mandarins, PS treatments did not control penicillium decay after $7 \mathrm{~d}$ incubation at $20^{\circ} \mathrm{C}$. 
In contrast, the same PS treatment applied to 'Ortanique' mandarins, 'Fino' lemons, and 'Valencia' oranges, reduced the incidence of green and blue molds by 80,50 , and more than $95 \%$, respectively. Moreover, while PS treatments at $62{ }^{\circ} \mathrm{C}$ for $60 \mathrm{~s}$ similarly controlled green and blue molds on 'Ortanique' mandarins and 'Valencia' oranges after $15 \mathrm{~d}$ of storage at $5{ }^{\circ} \mathrm{C}$, the effectiveness of the treatments was significantly lower on mandarins than on oranges after longer storage times. It was also observed in these cold storage tests that PS treatments were slightly more effective in controlling green mold than blue mold, which can be explained by the fact that $P$. italicum grows faster than $P$. digitatum below $10^{\circ} \mathrm{C}$ (Brown and Eckert, 2000). In the experiments in which PStreated fruit was incubated at $20^{\circ} \mathrm{C}$, similar effectiveness against both fungi or slightly better control of blue mold was observed. The varietal dependence of PS efficacy was further observed in the semicommercial experiments, where PS was used alone or combined with low doses of IZ. When applied to 'Valencia' oranges, a $1 \%$ PS solution at $45^{\circ} \mathrm{C}$ was as effective as IZ and the combination of the two treatments did not improve their effectiveness as stand-alone treatments. PS alone effectively controlled both green and blue molds even after two weeks of incubation at $20^{\circ} \mathrm{C}$. In contrast, the incidence of green mold after 9, 20, or $30 \mathrm{~d}$ of incubation at $20^{\circ} \mathrm{C}$ on naturally infected 'Marisol' clementine mandarins treated with PS at room temperature was only slightly lower than that on control fruit, even though higher concentrations of PS were used $(2 \%)$. In this trial, however, green mold was satisfactorily controlled by the mixture of PS and IZ or IZ alone. All these differences on treatment effectiveness clearly show the strong influence that intrinsic fruit characteristics may have on either fruit susceptibility to infection by $P$. digitatum and $P$. italicum or on fruit response to PS activity. In fact, the influence of the type of fruit on the performance of other food additives or GRAS substances was also reported in previous studies. Palou et al. (2001, 2002a) found that treatments with aqueous solutions of sodium bicarbonate or sodium carbonate for $150 \mathrm{~s}$ were significantly less effective against green and blue molds on mandarins than on oranges. Moreover, differences in the effectiveness of these salts on different citrus cultivars were also found when shorter immersion times were used (Montesinos-Herrero et al., 2007). Early studies clarified the general mode of action of PS as a fungicide. As explained by Eklund 
(1983), the fungicidal activity of undissociated sorbic acid is 10 to 600 times more effective than the dissociated form. Thus, the highest efficacy is achieved at the highest concentration of the undissociated form of sorbic acid in the solution, that occur when the $\mathrm{pH}$ of the medium where PS is dissolved is as low as 4.77, which is the $\mathrm{pk}_{\mathrm{a}}$ of PS (Bandelin, 1958). The toxicity of PS aqueous solutions at its natural $\mathrm{pH}$ of 7.8 is low, but when applied to citrus fruit they become more active within the wounds in the albedo tissue because of the relatively low $\mathrm{pH}$ in these wounds. Rind $\mathrm{pH}$ of citrus fruit ranges from 4 to 6 depending on the species and cultivar (Smilanick et al., 1999, 2005; Prusky et al., 2004) and, according to this, PS would be more effective against $P$. digitatum or $P$. italicum on fruit with lower rind $\mathrm{pH}$. However, such rind $\mathrm{pH}$ differences cannot explain alone the different effectiveness of the treatments among different citrus species and cultivars. In general, the inhibitory ability of low toxicity antifungal compounds such as PS or other food additives depends on the presence of residues of the compound within the wound infection courts occupied by the fungus and on interactions between this residue and constituents of the rind (Palou et al., 2001, 2002b; Smilanick et al., 1999). Apparently, the nature of such interactions would be different according to the citrus species and cultivar as a consequence of different flavedo and albedo characteristics or presence of different constituents (preformed antifungal compounds) in the rind. Additionally, such constituents and their concentration in the rind would be determined by not only the genotype but also the fruit physical and physiological condition. On the one hand, these factors determine the natural fruit susceptibility to decay; mature citrus fruits are typically more susceptible to decay than immature ones because, among other possible causes, their level of preformed antifungal compounds is lower. On the other hand, the biosynthesis and/or accumulation of antifungal compounds as a response to different postharvest treatments is also lower in mature fruit (BenYehoshua et al., 1992; Del Río and Ortuño, 2004; Ben-Yehoshua and Porat, 2005). It is known that an indirect mechanism of action of certain postharvest treatments such as heat (Ben-Yehoshua et al., 1992) or solutions of some GRAS compounds (Venditti et al., 2005) is the induction in the treated fruit tissues of disease resistance. According to these considerations and taking also into account that the inoculum density used for artificial inoculation was high $\left(10^{9}\right.$ conidia $\left.\mathrm{L}^{-1}\right)$ and the 
same for all species and cultivars, the relatively poor performance of the tested treatments on 'Nadorcott', 'Clemenules', or 'Marisol' mandarins could be explained by the weak physical condition of their rind and perhaps a reduced ability to synthesize antifungal compounds. At commercial maturity, the rind of these mandarin cultivars is typically soft and thin and they can ripen to an overmature stage during the postharvest phase easier and faster than other citrus species and cultivars. In contrast, 'Ortanique' is a mandarin hybrid especially valued because of the high level of firmness of its rind, its good tolerance for long-term cold storage, and its great resistance to injury during postharvest manipulation (Cohen et al., 1990). It appears clear, therefore, that the rind properties of 'Valencia' oranges or 'Ortanique' mandarins play a key role in their natural susceptibility to penicillium molds and consequently on the superior effectiveness of PS treatments. The influence of solution temperature on PS efficacy has been discussed, but it can also be concluded from this work that, besides other factors, this influence is lower than that of the characteristics of the treated fruit. Increasing solution temperature scarcely increased PS effectiveness on those cultivars in which it was either very low ('Nadorcott' or 'Clemenules') or very high ('Valencia'). In fact, on 'Valencia' oranges, PS treatments were highly effective against both green and blue molds even at room temperature. The effectiveness of PS treatments on these fruit was maintained after either $14 \mathrm{~d}$ of incubation at $20^{\circ} \mathrm{C}$ or $60 \mathrm{~d}$ of cold storage at $5{ }^{\circ} \mathrm{C}$. After different days of storage, depending on the citrus species and cultivar and the treatment conditions, the infections resumed. This result confirmed that the antifungal activity of PS against Penicillium spp. in citrus fruit is more fungistatic than fungicidal, as it has been also reported in other studies and for other food additives or GRAS compounds (Wild, 1987; Smilanick et al., 1999, 2008; Palou et al., 2001, 2002a,b). In general, the effect of factors like cultivar or fruit condition on treatment effectiveness is more important when low toxicity compounds such as food additives are intended to be used instead of stronger synthetic fungicides as postharvest treatments to control postharvest diseases. A thorough knowledge of the effect of these factors would give managers the option to discriminate in the packinghouse different lots of harvested fruit as a function of available postharvest treatments. 
Previous studies showed that some alternative disease control agents induced resistance to postharvest pathogens when fruit were treated before inoculation (El Ghaouth, 1994; Venditti et al., 2005). Venditti et al. (2005) treated wounded 'Fairchild' mandarins with sodium carbonate and found an accumulation of the phytoalexin scoparone in the albedo that associated with a decrease in disease severity. When wounded 'Biondo' oranges were treated and then inoculated after $3 \mathrm{~d}$, the incidence of green and blue molds was reduced by 97.2 and $93.9 \%$, respectively. In the present study, no differences in disease severity were observed when nonwounded 'Ortanique' mandarins or 'Valencia' oranges were treated with PS 1,2 , or $5 \mathrm{~d}$ prior to inoculation with $P$. digitatum. As reported by Venditti et al. (2005), the efficacy of the treatment in inducing resistance was related to its interaction with the albedo tissue. Thus, when the treatment was applied as a film on unwounded flavedo there was no effect in preventing contact infection by $P$. digitatum. Although such consideration could explain why no induced resistance was observed under the experimental conditions of the present work, additional research should be conducted to clarify if PS treatments can induce resistance to penicillium molds in citrus fruit.

In agreement with other studies in which a synergistic effect between PS and IZ treatments was found when they were applied on oranges previously inoculated with $P$. digitatum (Smilanick et al., 2008), the compatibility and benefits from the integration of PS and IZ treatments were also observed in our semicommercial trials with oranges and clementines. Although the high level of effectiveness of stand-alone treatments did not make the nature of the interaction evident, the combination of low concentrations of PS with IZ allowed a considerable reduction of the concentration of the latter without losing effectiveness in controlling green mold on naturally infected 'Marisol' clementine mandarins. The natural occurrence of blue mold was very low in this trial and no conclusive results were obtained.

Treatment conditions of $62{ }^{\circ} \mathrm{C}$ and 30 or $60 \mathrm{~s}$ would be appropriate for satisfactory control of both green and blue molds of citrus fruit with $3 \%$ PS solutions as part of an alternative integrated postharvest decay control program. These non-phytotoxic conditions would allow a reduction in the immersion time to at least half that required at temperatures of approximately $40{ }^{\circ} \mathrm{C}$ and make PS treatments more feasible for the 
industry, specifically by allowing the use of smaller tanks that would save time, material costs, and space in the packinghouses. These PS treatments are new tools that could be included in integrated disease management programs especially suitable for packinghouses with high levels of fungicide-resistant strains of Penicillium spp. or working with certain citrus cultivars destined to international markets with low or zero pesticide residue tolerances.

\section{Acknowledgements}

Mr. Federico Izquierdo from Fontestad S.A. (Montcada, València), Cooperativa de Bétera (Bétera, València), and Fomesa Fruitech S.L. (Beniparrell, València) are gratefully acknowledged for providing fruit and technical assistance. This work was partially funded by the Spanish 'Ministerio de Educación y Ciencia' (MEC; project AGL2004-05271) and the European Union (FEDER Program). Clara Montesinos-Herrero's doctorate program is supported by the IVIA.

\section{References}

Bandelin, F.J., 1958. The effect of $\mathrm{pH}$ on the efficiency of various mold inhibiting compounds. J. Am. Pharm. Assoc. 47, 691-694.

Ben-Yehoshua, S., Porat, R., 2005. Heat treatments to reduce decay. In: Ben-Yehoshua, S. (Ed.), Environmentally Friendly Technologies for Agricultural Produce Quality. CRC Press, Taylor and Francis Group, Boca Raton, FL, USA, pp. 11-42.

Ben-Yehoshua, S., Rodov, V., Kim, J. J., Carmeli, S., 1992. Preformed and induced antifungal materials of citrus fruits in relation to the enhancement of decay resistance by heat and ultraviolet treatments. J. Agric. Food Chem. 40, 1217-1221.

Brown, G.E., Eckert, J.W., 2000. Penicillium decays. In: Timmer, L.W., Garnsey, S.M., Graham, J.H. (Eds.), Compendium of Citrus Diseases, 2nd ed. APS Press, St. Paul, MN, USA, pp. 41-42.

Bus, V.G., Bongers, A.J., Risse, L.A., 1991. Occurrence of Penicillium digitatum and $P$. italicum resistant to benomyl, thiabendazole, and imazalil on citrus fruit from different geographic origins. Plant Dis. 75, 1098-1100. 
Chichester, D.F., Tanner, F.W.Jr., 1972. Antimicrobial food additives. In: Furia, T.E. (Ed.), Handbook of Food Additives, 2nd ed. CRC Press, Cleveland, OH, USA, pp. 155-184.

Cohen, E., Shalom, Y., Rosenberger, I., 1990. Post-harvest behaviour of 'Ortanique' ('Topaz') tangor citrus fruit during long-term storage at various temperatures. Sci. Hortic. 44, 235-240.

Del Río, J.A., Ortuño, A., 2004. Biosynthesis of flavonoids in citrus and its involvement in the antifungal defense mechanisms. In: Dris, R., Niskanen, R., Mohan Jain, S. (Eds.), Crop Management and Postharvest Handling of Horticultural Products, vol. 4, Diseases and Disorders of Fruits and Vegetables. Science Publishers Inc., Enfield, NH, USA, pp. 185-220.

Dezman, D.J., Nagy, S., Brown, G.E., 1986. Postharvest fungal decay control chemicals: treatments and residues in citrus fruits. Residue News 97, 37-92.

Eckert, J.W., Brown, G.E., 1986. Evaluation of postharvest treatments for citrus fruits. In: Hickey, K.D. (Ed.), Methods for Evaluating Pesticides for Control of Plant Pathogens. APS Press, St. Paul, MN, USA, pp. 92-97.

Eckert, J.W., Eaks, I.L., 1989. Postharvest disorders and diseases of citrus fruit. In: Reuther, W., Calavan, E.C., Carman, G.E. (Eds.), The Citrus Industry, vol. 5. University of California Press, Berkeley, CA, USA, pp. 179-260.

Eklund, T., 1983. The antimicrobial effect of dissociated and undissociated sorbic acid at different pH levels. J. Appl. Bacteriol. 54, 383-389.

El Ghaouth, A., 1994. Manipulation of defense systems with elicitors to control postharvest diseases. In: Wilson C.L., Wisniewski, M.E. (Eds.), Biological Control of Postharvest Diseases: Theory and Practise. CRC Press, Boca Raton, FL, USA, pp. 153-167.

Hall, D.J., 1988. Comparative activity of selected food preservatives as citrus postharvest fungicides. Proc. Fla. State Hort. Soc. 101, 184-187.

Holmes, G.J., Eckert, J.W., 1999. Sensitivity of Penicillium digitatum and $P$. italicum to postharvest citrus fungicides in California. Phytopathology 89, 716-721.

Kinay, P., Mansour, M.F., Mlikota Gabler, F., Margosan, D.A., Smilanick, J.L., 2007. Characterization of fungicide-resistant isolates 
of Penicillium digitatum collected in California. Crop Prot. 26, 647656.

Kitagawa, H., Kawada, K., 1984. Effect of sorbic acid and potassium sorbate on the control of sour rot of citrus fruits. Proc. Fla. State Hort. Soc. 97, 133-135.

Larrigaudière, C., Pons, J., Torres, R., Usall, J., 2002. Storage performance of clementines treated with hot water, sodium carbonate and sodium bicarbonate dips. J. Hortic. Sci. Biotechnol. 77, 314-319.

Lindsay, R.C. 1996. Food additives. In: Fennema, O.R. (Ed.), Food Chemistry, 3th ed. Marcel Decker, Inc., New York, USA, pp. 767823.

Montesinos-Herrero, C., del Río, M.A., Pastor, C., Palou, L., 2007. Brief immersion in heated solutions of sodium bicarbonate and sodium carbonate to control postharvest green and blue molds of citrus fruit. In: Proc. 5th Int. Congr. Food Technology, vol. 1, Thessaloniki, Greece, 9-11 March, pp. 470-475.

Palou, L., Marcilla, A., Rojas-Argudo, C., Alonso, M., Jacas, J.A., del Río, M.A., 2007. Effects of X-ray irradiation and sodium carbonate treatments on postharvest Penicillium decay and quality attributes of clementine mandarins. Postharvest Biol. Technol. 46, 252-261.

Palou, L., Smilanick, J.L., Droby, S., 2008. Alternatives to conventional fungicides for the control of citrus postharvest green and blue molds. Stewart Postharv. Rev. 2:2, 1-16.

Palou, L., Smilanick, J.L., Usall, J., Viñas, I., 2001.Control of postharvest blue and green molds of oranges by hot water, sodium carbonate, and sodium bicarbonate. Plant Dis. 85, 371-376.

Palou, L., Usall, J., Muñoz, J.A., Smilanick, J.L., Viñas, I., 2002a. Hot water, sodium carbonate, and sodium bicarbonate for the control of postharvest green and blue molds of Clementine mandarins. Postharvest Biol. Technol. 24, 93-96.

Palou, L., Usall, J., Smilanick, J.L., Aguilar, M.J., Viñas, I., 2002b. Evaluation of food additives and low-toxicity compounds as alternative chemicals for the control of Penicillium digitatum and Penicillium italicum on citrus fruit. Pest Manag. Sci. 58, 459-466.

Porat, R., Daus, A., Weiss, B., Cohen, L., Droby, S., 2002. Effects of combining hot water, sodium bicarbonate and biocontrol on 
postharvest decay of citrus fruit. J. Hortic. Sci. Biotechnol. 77, 441445.

Porat, R., Daus, A., Weiss, B., Cohen, L., Fallik, E., Droby, S., 2000. Reduction of postharvest decay in organic citrus fruit by a short hot water brushing treatment. Postharvest Biol. Technol. 18, 151-157.

Prusky, D., McEvoy, J.L., Saftner, R., Conway, W.S., Jones, R., 2004. Relationship between host acidification and virulence of Penicillium spp. on apple and citrus fruit. Phytopathology 94, 44-51.

Schirra, M., D'hallewin, G., Ben-Yehoshua, S., Fallik, E., 2000. Hostpathogen interaction modulated by heat treatment. Postharvest Biol. Technol. 21, 71-85.

Smilanick, J.L., Brown, G.E., Eckert, J.W., 2006. Postharvest citrus diseases and their control. In: Wardowski, W.F., Miller, W.M., Hall, D.J., Grierson, W. (Eds.), Fresh Citrus Fruits, 2nd ed. Florida Science Source, Inc., Longboat Key, FL, USA, pp. 339-396.

Smilanick, J.L., Mackey, B.E., Reese, R., Usall, J., Margosan, D.A., 1997. Influence of concentration of soda ash, temperature, and immersion period on the control of postharvest green mold of oranges. Plant Dis. 81, 379-382.

Smilanick, J.L., Mansour, M.F., Margosan, D.A., Mlikota Gabler, F., 2005. Influence of $\mathrm{pH}$ and $\mathrm{NaHCO}_{3}$ on effectiveness of imazalil to inhibit germination of Penicillium digitatum and to control postharvest green mold on citrus fruit. Plant Dis. 89, 640-648.

Smilanick, J.L., Mansour, M.F., Mlikota Gabler, F., Sorenson, D., 2008. Control of citrus postharvest green mold and sour rot by potassium sorbate combined with heat and fungicides. Postharvest Biol. Technol. 47, 226-238.

Smilanick, J.L., Margosan, D.A., Mlikota Gabler, F., Usall, J., Michael, I.F., 1999. Control of citrus green mold by carbonate and bicarbonate salts and the influence of commercial postharvest practices on their efficacy. Plant Dis. 83, 139-145

Smilanick, J.L., Sorenson, D., 2001. Control of postharvest decay of citrus fruit with calcium polysulfide. Postharvest Biol. Technol. 21, 157-168.

Smilanick, J.L., Sorenson, D., Mansour, M.F., Aieyabei, J., Plaza, P., 2003. Impact of a brief postharvest hot water drench treatment on 
decay, fruit appearance, and microbe populations of California lemons and oranges. HortTechnology 13, 333-338.

Smoot, J.J., McCornack, A.A., 1978. The use of potassium sorbate for citrus decay control. Proc. Fla. State Hort. Soc. 91, 119-122.

Tuset, J.J., 1987. Podredumbres de los Frutos Cítricos. Conselleria d'Agricultura i Pesca. Generalitat Valenciana, València, Spain (In Spanish).

US EPA (United States Environmental Protection Agency), 2005. Updating generic pesticide chemical tolerance regulations. Final rule. Fed. Reg. 70, 33354-33363.

Venditti, T., Molinu, M.G., Dore, A., Agabbio, M., D’hallewin, G., 2005. Sodium carbonate treatment induces scoparone accumulation, structural changes, and alkalinization in the albedo of wounded citrus fruits. J. Agric. Food Chem. 53, 3510-3518.

Wild, B.L., 1987. Fungicidal activity of potassium sorbate against Penicillium digitatum as affected by thiabendazole and dip temperature. Sci. Hortic. 32, 41-48.

York, G.K., Vaughn, R.H., 1964. Mechanisms in the inhibition of microorganisms by sorbic acid. J. Bacteriol. 88, 411-417. 
Chapter 2 
Chapter 3

\title{
Potassium sorbate residue levels and persistence in citrus fruit as detected by a simple colorimetric method
}

\author{
CLARA MONTESINOS-HERRERO ${ }^{1}$, JOSEPH L. SMILANICK ${ }^{2}$, \\ J. MICHAEL HURLEY ${ }^{3}$ and LLUÍS PALOU ${ }^{1}$ \\ ${ }^{1}$ Laboratori de Patologia, Centre de Tecnologia Postcollita (CTP) \\ Institut Valencià d'Investigacions Agràries (IVIA) \\ Apartat Oficial, 46113 Montcada, València, Spain \\ ${ }^{2}$ USDA-ARS, San Joaquin Valley Agricultural Sciences Center \\ 9611 South Riverbend Avenue, Parlier, CA 93648, USA \\ ${ }^{3}$ Dried Fruit Association of California Laboratory \\ 1855 S. Van Ness, Fresno, CA 93721, USA
}

Reference: Journal of Agriculture and Food Chemistry 2009, 57, 34583463. 



\begin{abstract}
A colorimetric method that employed extraction of the macerated fruit, followed by reaction with 2-thiobarbituric acid, was used to quantify potassium sorbate residues in citrus fruit. A recovery of more than $90 \%$ in oranges and lemons was obtained. Potassium sorbate residues determined by this method and a standard HPLC method were similar. Residues were proportionate to the potassium sorbate concentration in the treatment solution. In oranges stored at $15^{\circ} \mathrm{C}$ following the potassium sorbate treatments, residues declined initially rapidly and later more slowly, until residues stopped declining after 6 days. A brief double-dip rinse in tap water applied immediately after immersion of lemons in a $2 \%$ $(\mathrm{wt} / \mathrm{vol})$ potassium sorbate removed more than $90 \%$ of the potassium sorbate residue. The influence of high pressure water washing (HPWW) on potassium sorbate residues in potassium sorbate-treated fruit was determined. Potassium sorbate residues were more effectively reduced by rinsing oranges than lemons.
\end{abstract}

Keywords: alternative antifungal postharvest treatments; GRAS; lemon; orange; spectrophotometric method; penicillium decay

\title{
INTRODUCTION
}

Sorbic acid and its water-soluble salts, especially potassium sorbate, are common food preservatives. Sorbates are the best characterized of all food antimicrobials as to their broad-spectrum of action. They effectively inhibit certain bacteria and food-borne yeast and mold species (1). Their use for the control of postharvest diseases of citrus fruit was first evaluated by Smoot and McCormack (2). Later, Nelson et al. (3) combined potassium sorbate with benzimidazoles and found some improvement in the control of resistant strains of Penicillium digitatum. Kitagawa and Kawada (4) found that potassium sorbate was as effective as sodium o-phenylphenate to control sour rot on lemons, and Wild (5) showed that potassium sorbate was approximately $1 / 5$ as active as sodium o-phenylphenate against green mold on 'Valencia' oranges. Potassium sorbate was used commercially to retard citrus postharvest 
decay, but its use did not become popular because its efficacy was sometimes low, and it was reported to delay, rather than stop, green mold infections $(6,7)$. However, the rise in fungicide-resistant strains of pathogenic fungi, together with the increasing concern about environmental and health risks, has elicited interest in finding alternatives to conventional synthetic fungicides for postharvest treatment of fresh fruit. The use of potassium sorbate alone, heated and/or combined with fungicides has been recently studied with citrus fruit $(8,9)$. Dip treatments with potassium sorbate solutions significantly reduced sour rot incidence on lemons and its effectiveness was improved by heat (9). When used against green and blue molds, potassium sorbate effectiveness strongly depended on citrus cultivar and species, being generally more effective on oranges than on mandarins (8). The use of potassium sorbate as an alternative to synthetic fungicides has also been studied on other fruits like table grapes (10) and cherries (11).

Although the performance of potassium sorbate treatments to control decay on citrus fruit has been rigorously studied, little is known about the level of potassium sorbate residues remaining in treated fruit. Potassium sorbate residues that remain after treatment may be an issue to some buyers. At one time registered as a fungicide in the US, potassium sorbate was more recently listed as a "minimum risk pesticide" by the US EPA and exempt from residue tolerance requirements (12). However, regulations in other countries are not clear about the level of residue permitted in citrus fruit, and the use of potassium sorbate is prohibited for use under most 'organic' crop production rules. Sorbates leave a persistent antimicrobial residue in food products they protect (13), and it is possible they provide a persistent residue in citrus fruit. An accurate assessment of the fungicidal activity of potassium sorbate requires the development of a method for analysis of potassium sorbate in whole fruit so that experimental application, storage, and shipping tests can be evaluated.

Methods for determination of potassium sorbate in food products traditionally included distillation and subsequent determination by ultraviolet absorption and titration techniques $(14,15)$. The initial Association of Official Analytical Chemists (AOAC) methods (15) required extensive sample preparation and relatively long analysis times, and did not give accurate results at low levels. Park and Nelson (17) 
described a method for determining sorbic acid in citrus fruit by reverse phase HPLC. The method involved extraction of the peel with methanol, cleanup of the extract by solvent partitioning and column chromatography, and quantitative determination by HPLC using ultraviolet detection. Distillation, or extraction with methanol, is timeconsuming, and HPLC methods are not adaptable for use by small processors, because they lack technical personnel and equipment costs are high. Nury and Bolin (18) described a simple, direct colorimetric method requiring no distillation for the determination of potassium sorbate in dried fruits. The method made use of the oxidation of sorbic acid to malonaldehyde, which reacts with thiobarbituric acid to form a red pigment that was measured photometrically. Different adaptations of this method, using the same basic reaction, have been used in the determination of sorbic acid in wines (19).

This study investigated a simple colorimetric method for the determination of potassium sorbate in citrus fruit based on the previously mentioned reaction with thiobarbituric acid. This method was applied in this study to: (a) evaluate the influence of potassium sorbate concentration on the residue level in treated fruit; (b) determine the effectiveness of water rinse and high pressure water wash in removing potassium sorbate residues from treated fruit; and (c) assess the evolution of potassium sorbate residue level in treated fruit during storage.

\section{MATERIALS AND METHODS}

Fruit. 'Eureka' lemons or 'Atwood' navel oranges were used in this study. Lemons were collected from field bins in a packinghouse in Tulare County (California, USA) one day after harvest. The oranges originated from a grove of the University of California, Lindcove Research and Extension Center in Exeter (California). No postharvest treatments had been applied. Before use, fruits were stored at $15{ }^{\circ} \mathrm{C}$ for less than two weeks. Fruits were randomized before the experiments.

Spectrophotometric method for the analysis of potassium sorbate residues in citrus. A colorimetric assay for potassium sorbate in dried fruits (18) was adapted for its use in the analysis of potassium sorbate residues in citrus fruit.

Reagents. All reagents used were analytical-reagent grade. Doubly deionized water $(18 \mathrm{M} \Omega)$ was used. A potassium sorbate working 
solution $(0.1 \% \mathrm{wt} / \mathrm{vol})$ was prepared from potassium salt of sorbic acid (min. 99\%) (Sigma-Aldrich, St. Louis, Missouri, USA). A 1:1 mixture of $0.01 \mathrm{~N} \mathrm{~K}_{2} \mathrm{Cr}_{2} \mathrm{O}_{7}$ and $0.3 \mathrm{~N}$ was prepared from potassium dichromate (min. 99.5\%) (Sigma-Aldrich) and sulfuric acid (95-97\%) (A.C.S. reagent, Sigma-Aldrich). For the preparation of 2-thiobarbituric acid, 0.5 $\mathrm{g}$ of 2-thiobarbituric acid (min. 98\%) (Sigma-Aldrich) was dissolved in $20 \mathrm{~mL}$ water and $10 \mathrm{~mL}$ of $1 \mathrm{~N} \mathrm{NaOH}$ in a $100-\mathrm{mL}$ volumetric flask. After dissolving, $11 \mathrm{~mL}$ of $1 \mathrm{~N} \mathrm{HCl}$ were added and the solution was made to $100-\mathrm{mL}$ volume. The 2-thiobarbituric acid solution was made fresh daily. The reagent remains relatively unchanged for about $6 \mathrm{~h}$, but after that time absorbance values are lower, resulting in erroneous results (18).

Standard curve. The standard curve was prepared from non-treated fruit. One whole fruit was weighed, cut into pieces, and blended with $0.95 \mathrm{~mL}$ water per $1 \mathrm{~g}$ of fruit for $1 \mathrm{~min}$. Ten grams of the slurry were poured in each of five $250-\mathrm{mL}$ volumetric flasks and fortified with $0,0.25,0.5$, 0.75 , or $1.0 \mathrm{~mL}$ volume of the standard sorbate solution $(0.1 \% \mathrm{wt} / \mathrm{vol})$. Each flask was filled till $250-\mathrm{mL}$ volume with water to reach the concentration of $0,1,2,3$, or $4 \mathrm{mg} / \mathrm{L}$ of potassium sorbate in solution, respectively. A volume of $30 \mathrm{~mL}$ were transferred to centrifuge tubes and centrifuged at $14,500 \mathrm{x}$ g for $7 \mathrm{~min}$. A $2 \mathrm{~mL}$ volume of each of the supernatants was added to each of five test tubes containing $2 \mathrm{~mL}$ of potassium dichromate-sulfuric acid solution. This mixture was heated for $5 \mathrm{~min}$ at approximately $100{ }^{\circ} \mathrm{C}$ in a water bath. Then $2 \mathrm{~mL}$ of the thiobarbituric acid solution were added to each of the tubes and they remained in the bath for an additional 10 min time. The tubes were then removed and quickly cooled in running tap water. Absorbance was measured at $530 \mathrm{~nm}$ in a spectrophotometer (UV-VIS spectrophotometer, UV Mini 1240, Shimadzu, China). Water was used as a blank. A standard curve was obtained by plotting absorbance versus $\mathrm{mg} / \mathrm{L}$ of potassium sorbate. Two standard curves, one for lemons and one for oranges, were prepared.

Sample preparation. Potassium sorbate residues in lemons within each replicate of 27 pieces of fruit were determined by taking three lemons and following the protocol described previously. When oranges were analyzed, two pieces of fruit were used for each replicate of 20 oranges. 
Calculations. Optical absorbance was applied to the regression describing the slope of the standard curve to calculate the potassium sorbate concentration of this value. This value was adjusted by multiplying it by 48.78 (conversion factor to reflect the dilution and express the final value in $\mathrm{mg}$ of potassium sorbate per $\mathrm{kg}$ of fruit).

Recovery. Residue recovery was determined in ten replicates by spiking fresh samples of lemons and oranges with $200 \mathrm{mg} / \mathrm{kg}$ potassium sorbate in fruit before blending the fruit. They were analyzed as previously described to estimate the recovery of the colorimetric method.

Effect of a water rinse on removal of potassium sorbate residues in lemons. Lemons were immersed for $1 \mathrm{~min}$ in $15-\mathrm{L}$ volume of water at $25{ }^{\circ} \mathrm{C}$ (control) or $2 \%\left(\mathrm{wt} / \mathrm{vol}\right.$ ) potassium sorbate at $25,40,50$ or $62{ }^{\circ} \mathrm{C}$. The temperature of the solutions did not change more than $0.5^{\circ} \mathrm{C}$ during treatment. Immediately after the immersion, lemons were rinsed by two immersions of $1 \mathrm{~s}$ each in tap water, left to dry in air, and stored at $15{ }^{\circ} \mathrm{C}$ for $24 \mathrm{~h}$. At that time, the colorimetric analysis for the detection of potassium sorbate as previously described was used to determine the residues in fruit.

Effect of a high pressure water wash (HPWW) on removal of potassium sorbate residues in citrus fruit. The effectiveness of HPWW to remove potassium sorbate residues in citrus fruit treated with potassium sorbate was assessed before and after cold storage for 25 days at $15^{\circ} \mathrm{C}$. In order to compare removal of residues from fruit from the two HPWW times, two sets of fruit (three replicates of 20 oranges or three replicates of 27 lemons) were immersed for $1 \mathrm{~min}$ in water at $25{ }^{\circ} \mathrm{C}$ (control treatment) or in aqueous solutions containing $2 \%$ (wt/vol) potassium sorbate at $25^{\circ} \mathrm{C}$. After immersion, the fruit were left to dry and then stored at $15^{\circ} \mathrm{C}$. Samples from each treatment from one of the sets were analyzed for potassium sorbate residues the same day of the treatment. The next day, one set of fruit was again analyzed for residues and the other set was rinsed by HPWW and then analyzed. Both sets of fruit were then stored at $15{ }^{\circ} \mathrm{C}$ for 25 days. At the end of the storage period, both sets of fruit were again analyzed for potassium sorbate residues. HPWW was applied to the set of fruit that had not been rinsed and these fruit were analyzed for potassium sorbate residues. All HPWW treatments were applied at the Fruit Evaluation Center Packline of the University of California Lindcove Research and Extension Center, in 
Exeter, California, USA. A pressure washer (Food Machinery Corporation, Lindsay, California, USA) delivered 2,000 $\mathrm{kPa}$ high pressure, room temperature water over rotating brushes. The Tufted Polycor pressure water brushes (Industrial Brush Co., Pomona, California, USA) were $61 \mathrm{~cm}$ wide and $11.43 \mathrm{~cm}$ in diameter. The filaments of the brush were $38 \mathrm{~mm}$ in diameter with 20 tufts per circumference. The brushes rotated at $80 \mathrm{rpm}$. Fruit was moved across the spraying area at a $6.35 \mathrm{~cm} / \mathrm{s}$ speed, with a residence time of about 30 $\mathrm{s}$ inside the washer. The openings of the water delivery nozzles were 24 $\mathrm{cm}$ above the top of the brushes. The water contained about $30 \mu \mathrm{L} / \mathrm{L}$ total chlorine (12.5\% sodium hypochlorite) (Brogdex Co., Pomona, California, USA) with a $6.5 \mathrm{pH}$ was applied over the brushes through a single 1.9-m-long row of solid-cone nozzles at $9.53-\mathrm{cm}$ intervals, on a 2.54-cm inside diameter pipe down the center of the brush bed. Each nozzle delivered $306 \mathrm{~L} / \mathrm{s}$ of water at 2,000 $\mathrm{kPa}$. These tests were repeated twice with both lemons and oranges.

Assessment of the decline in potassium sorbate residue concentration in oranges. In order to measure the concentration of potassium sorbate during storage, oranges were treated by immersion in water at $25{ }^{\circ} \mathrm{C}$ (control) or in aqueous solutions containing $0.5,1.0,2.0$ or $3.0 \mathrm{~g} / \mathrm{L}$ potassium sorbate, left to dry in air, and stored at $15{ }^{\circ} \mathrm{C}$. Potassium sorbate residues were analyzed the day of the treatment and after 1, 2, 3, $4,5,6,12,19$, and 26 days of cold storage. Only the measurements at days 1, 12, 19 and 26 were repeated in another experiment.

Statistical analysis. All treatments to oranges or lemons were applied to three replicates of 20 or 27 fruit each, respectively. Within each replicate, three lemons or two oranges were used for each analysis of potassium sorbate residues. Experiments were repeated twice and data shown are means of two experiments (unless otherwise stated). Results were compared using analysis of variance (ANOVA), and means were separated by Fisher's least significant difference test (LSD; $P=0.05)$. In order to estimate the correlation between absorbance and potassium sorbate concentration on the standard curves, Pearson's correlation index was used. Statistics were analyzed using SPSS software (SPSS version 16; SPSS Inc., Chicago, Illinois, USA). 


\section{RESULTS AND DISCUSSION}

Spectrophotometric method for the analysis of potassium sorbate residues in citrus. The method we employed is based on the conversion of potassium sorbate to sorbic acid and its subsequent oxidation by potassium dichromate-sulfuric acid to malonaldehyde, which reacts with 2-thiobarbituric acid to form a reddish-pink product with a single absorption maximum at $530 \mathrm{~nm}$. The amount of thiobarbituric acid lost is about $40 \%$ after 14 days and $100 \%$ after 30 days at ambient temperature (18). Because the reaction proceeds slowly at room temperature, it must be performed at $100{ }^{\circ} \mathrm{C}$, but before measuring the absorbance of the reaction mixture, it must be cooled in running tap water. The colored solution, after cooling, is stable for at least one-half hour.

Two standard curves, one for lemons and a second for oranges, were obtained from solutions prepared to equal concentrations of 0 to $4 \mathrm{mg} / \mathrm{L}$ potassium sorbate. Pearson's correlation coefficient for the linear standard curves for lemons and oranges was 1.000 in both cases. The correlation equations and their corresponding $\mathrm{R}^{2}$ were: $\mathrm{y}=0.0899 \mathrm{x}+$ 0.1004 and 0.9998 for oranges and $y=0.0717 x+0.0622$ and 0.9999 for lemons (data not shown). The relative standard deviation of ten replicate determinations of $200 \mathrm{mg} / \mathrm{kg}$ of potassium sorbate in lemons was $3.18 \%$. Recovery of $200 \mathrm{mg} / \mathrm{kg}$ potassium sorbate, added to the fruit in the blender before mixing with water, recovered an average of $93.45 \%$ with a standard deviation of $3.4 \%$.

While potassium sorbate contents ( \pm SD) determined with this spectrophotometric method in four orange samples that had been immersed in $2 \%$ (wt/vol) potassium sorbate were $25.96 \pm 4.01 \mathrm{mg} / \mathrm{kg}$, they were $16.90 \pm 3.15 \mathrm{mg} / \mathrm{kg}$ in the same samples determined with a standard HPLC method, conducted by the Dried Fruit Association of California laboratory (Fresno, California). Differences in extraction efficiency may account for these slightly different results.

Effect of a water rinse on removal of potassium sorbate residues in lemons. This set of experiments was designed to assess the effect of a water rinse applied right after the immersion of the fruit in potassium sorbate solutions, which is a routine that may be followed in some cases to avoid potential adverse effects on fruit quality (8). A brief double-dip rinse with tap water, applied immediately after treatment of lemons with $2 \%\left(\mathrm{wt} / \mathrm{vol}\right.$ ) potassium sorbate for $1 \mathrm{~min}$ at $25,40,50$ or $62{ }^{\circ} \mathrm{C}$, almost 
completely removed the residues of potassium sorbate in the fruit. In lemons treated at $25^{\circ} \mathrm{C}$, removal of potassium sorbate residues approached $99 \%$ compared with the amount of residue present in similarly treated, non-rinsed lemons. As treatment temperatures were increased, the amount of potassium sorbate removed from the fruit decreased to $92 \%$ in lemons treated at $62{ }^{\circ} \mathrm{C}$ (Figure 1). Potassium sorbate is a highly water soluble salt that was easily removed from the surface of fruit when a simple water rinse was applied immediately after treatment. However, the effect of potassium sorbate treatments on the control of decay caused by $P$. digitatum and $P$. italicum is still important even after rinsing $(7,8)$. This could be explained by the fact that these pathogens can only infect through wounds in the rind, where presumably a portion of the potassium sorbate may be trapped during treatments, not eliminated by the water rinse, and thus still active. Smilanick et at. (20) found that immersion treatments in sodium carbonate or bicarbonate followed by water spray onto fruit did not influence the effectiveness of the treatments to control green mold. It was discussed that since spores survive the treatments of 1 or $2 \mathrm{~min}$ in duration that control green mold on fruit (21), it was probable that a residue of carbonate or bicarbonate remained in the fruit, or at least within the wound infection courts occupied by the pathogen, so the treatment inhibited the infection. This study shows that potassium sorbate residues were slightly more difficult to remove when potassium sorbate was applied at higher temperatures. Presumably, the absorption rates of potassium sorbate were higher at high temperature because of increased metabolism rates.

In studies evaluating hot water treatments to reduce postharvest decay on citrus fruit, some rind injury was observed at treatment temperatures of $53{ }^{\circ} \mathrm{C}$ or higher, and severe rind damage at $60{ }^{\circ} \mathrm{C}(22)$, including melting and/or removal of epicuticular waxes $(23,24)$. The influence of dip temperature on the residue level of fludioxonil was also studied (24), and it was found that there was no difference in the fludioxonil residue level between fungicide solution temperatures of 20 and $40{ }^{\circ} \mathrm{C}$, but residue levels proportionally increased with temperature in oranges dipped at temperatures of 50 and $60{ }^{\circ} \mathrm{C}$. Higher depositions of imazalil at higher dip temperatures were also found in other studies $(25,26)$. 


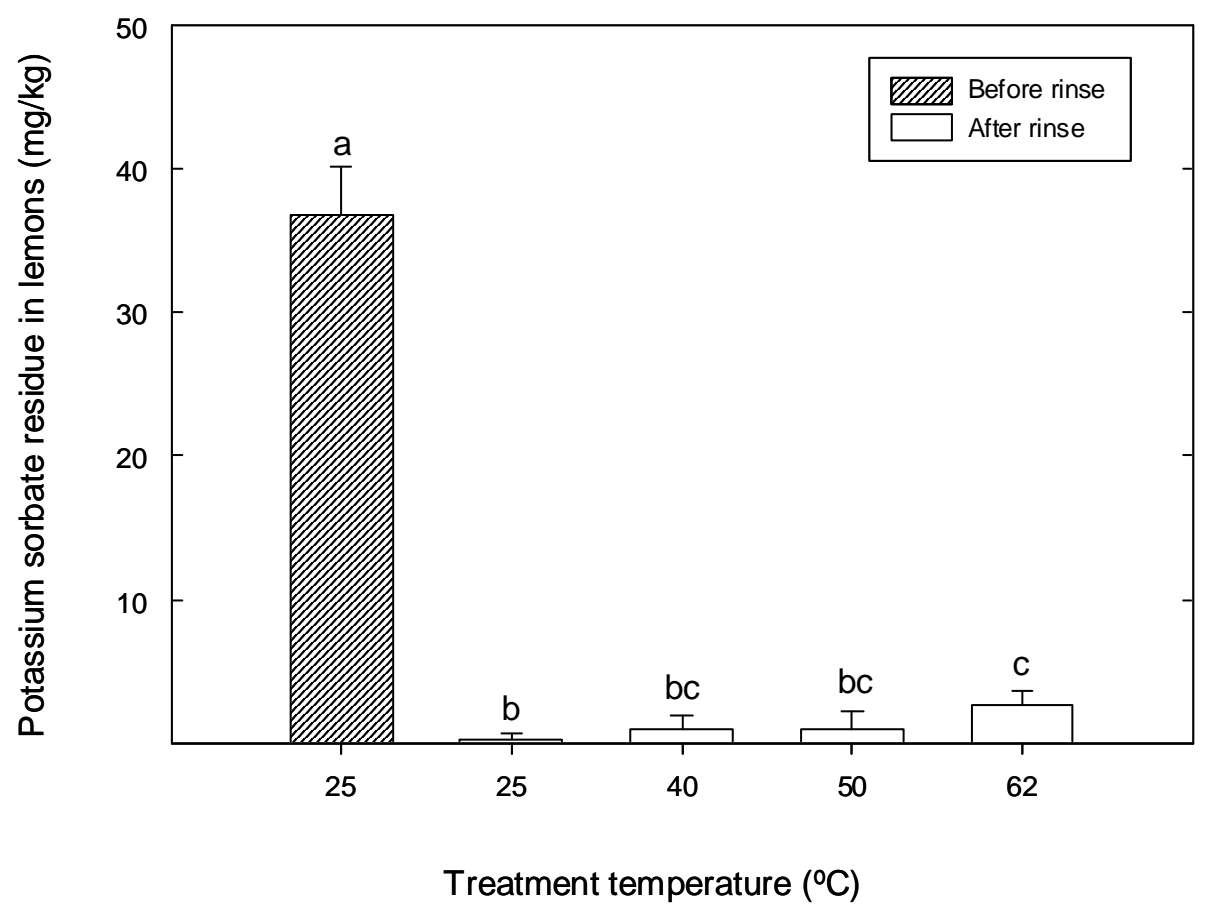

Figure 1. Effectiveness of double-dip rinse, applied immediately after treatment, on removal of potassium sorbate residues in lemons treated with $2 \%(\mathrm{wt} / \mathrm{vol})$ potassium sorbate for $1 \mathrm{~min}$ at different temperatures. Columns with the same letter are not significantly different according to Fisher's Protected LSD test $(P$ $<0.05)$. 


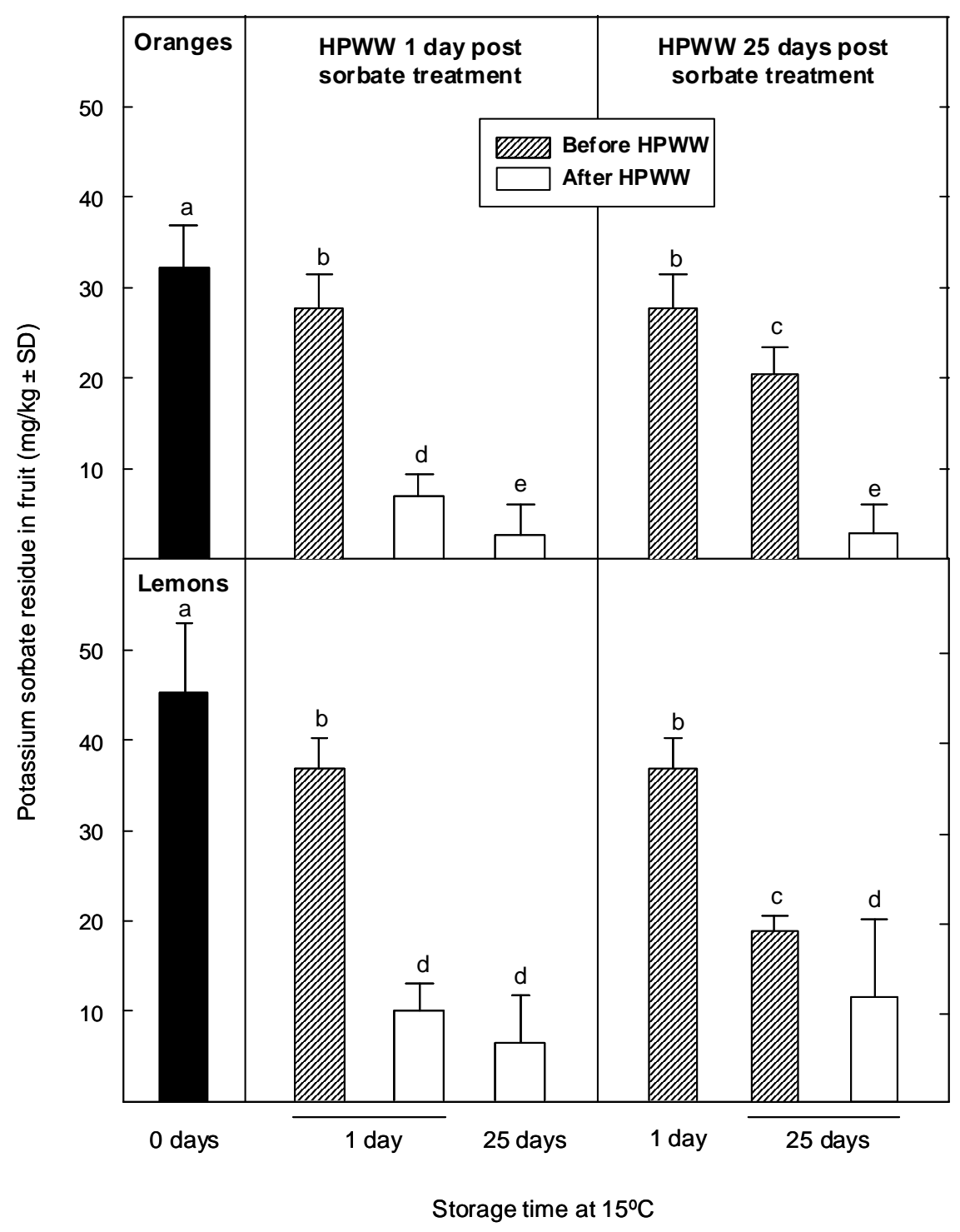

Figure 2. Influence of high pressure water washing (HPWW), applied 1 or 25 days after treatment, on potassium sorbate residues in fruit treated with $2 \%$ (wt/vol) potassium sorbate at $25^{\circ} \mathrm{C}$ for $1 \mathrm{~min}$. After treatment, fruit was stored at $15{ }^{\circ} \mathrm{C}$. For each type of fruit, columns with the same letter are not significantly different according to Fisher's Protected LSD test $(P<0.05)$. 
Effect of a high pressure water wash (HPWW) on removal of potassium sorbate residues in citrus fruit. HPWW is another procedure that may be used in some cases to clean the fruit and remove superficial chemical residues. Washing fruit with water at high pressure significantly removed the amount of residues present on the surface of lemons and oranges. However, the amount of potassium sorbate removed depended on the type of fruit and the time elapsed between treatment application and HPWW (Figure 2). The concentration of potassium sorbate residue in oranges and lemons decreased after 1 day of storage at $15^{\circ} \mathrm{C}$ by 5 and $19 \%$, respectively. When HPWW was applied one day after potassium sorbate treatment, on either oranges or lemons, the removal of residue was similar ( 75 and $73 \%$, respectively). During the 25-days cold storage period, potassium sorbate residues remaining in the HPWW-treated fruit continuously decreased. In oranges, residues decreased by $96 \%$ of the initial concentration while in lemons they decreased by $86 \%$. In non-rinsed oranges and lemons stored at $15{ }^{\circ} \mathrm{C}$ for 25 days, potassium sorbate residues decreased by 28 and $58 \%$ during that period, respectively. When the fruit were rinsed by HPWW at the end of the 25-days storage period, $87 \%$ of the previous residue content in stored oranges was removed (to a $93 \%$ less of the potassium sorbate initial content), while in lemons this percentage was 39\% (74\%). The fact that the potassium sorbate content in the fruit was decreasing during storage probably is a consequence of potassium sorbate residues on the surface of the fruit progressively migrating into the rind where, apparently, some of the potassium sorbate is metabolized and transformed into other substances no longer detectable as potassium sorbate or sorbic acid by the colorimetric method. As shown in this study, a brief water rinse removes most of the potassium sorbate residues on the surface of the fruit when applied immediately after treatment, when most of potassium sorbate is supposed to be found on the surface of fruit. Smilanick et al. (20) washed 'Atwood' navel oranges treated with sodium carbonate with a $1,380 \mathrm{kPa}$ pressure water wash and found that washing significantly reduced the control of green mold by carbonate treatment compared to non-washed oranges or those rinsed briefly with water. They suggested that salt residues were probably removed from the surface of fruit. In our study, the pressure used in the HPWW was $2,000 \mathrm{kPa}$, a much rigorous and much longer procedure than a brief water rinse, which should have 
been able to remove the potassium sorbate residues from the fruit surface. However, when applied after storage for 1 day, some of the residues had already migrated into the rind and were no longer eliminated by the wash, but remained in the fruit and could be detected when we macerated the fruit to release them before the analysis. Fruit that were HPWW rinsed and then stored for 25 days presented lower potassium sorbate content than they did just after the HPWW rinse, again probably due to some migration and degradation of the potassium sorbate. When the fruit were first stored and then HPWW rinsed, only the remaining potassium sorbate residues on the skin surface were removable by washing. The proportion of potassium sorbate removed from the surface of oranges at the end of the storage period was higher than that removed from lemons. This, together with the fact that residues in lemons also decreased faster during storage, may indicate that the rind of lemons was more permeable to potassium sorbate than the rind of oranges. However, once potassium sorbate had migrated into the rind of the fruit, a higher proportion of it remains non-metabolized, and thus detectable, in the case of lemons than in oranges. Moreover, whenever the HPWW is applied, either at the beginning or the end of the storage period, the amount of potassium sorbate in either oranges or lemons at the end of storage was the same. In oranges, only $4 \%$ of the initial potassium sorbate content remained after HPWW and 25 days or storage (or 25 days of storage and HPWW), while in similarly treated lemons, $20 \%$ of the initial residue content remained. If the hypothesis of potassium sorbate being metabolized is confirmed, the difference between HPWW applied at the beginning or at the end of the storage period would be that, when HPWW is applied at the beginning, a higher proportion of potassium sorbate is topical and it is readily washed away, while when HPWW is applied at the end of storage, a larger portion of the potassium sorbate residues had already migrated into the rind, with some portion being metabolized, and they would not be removed. In other words, more potassium sorbate metabolites are probably found in fruit when it is washed at the end of the storage period. Differences between oranges and lemons in permeability, chemical composition, $\mathrm{pH}$, or number of openings present in the fruit rind may cause potassium sorbate to migrate and decompose in the rind and consequently influence the efficiency of HPWW treatment to remove the residue. 
Assessment of the decline in potassium sorbate residues in oranges. Potassium sorbate content was analyzed in oranges treated with different concentrations of potassium sorbate for $1 \mathrm{~min}$ at $25^{\circ} \mathrm{C}$ and stored at 15 ${ }^{\circ} \mathrm{C}$. The analyses were conducted during storage to quantify the decrease in the residue content among lemons and oranges that was observed in previous experiments in this study (not shown). Results from daily and bimonthly measurements are shown in Figure 3 and Figure 4, respectively. Regardless the length of storage, higher potassium sorbate concentration in the treatment deposited proportionately higher residues in the fruit. The amount of potassium sorbate residues consistently decreased from day 0 (measured immediately after the treatment) to day 6 (6 days after the treatment), generally with a more acute decline

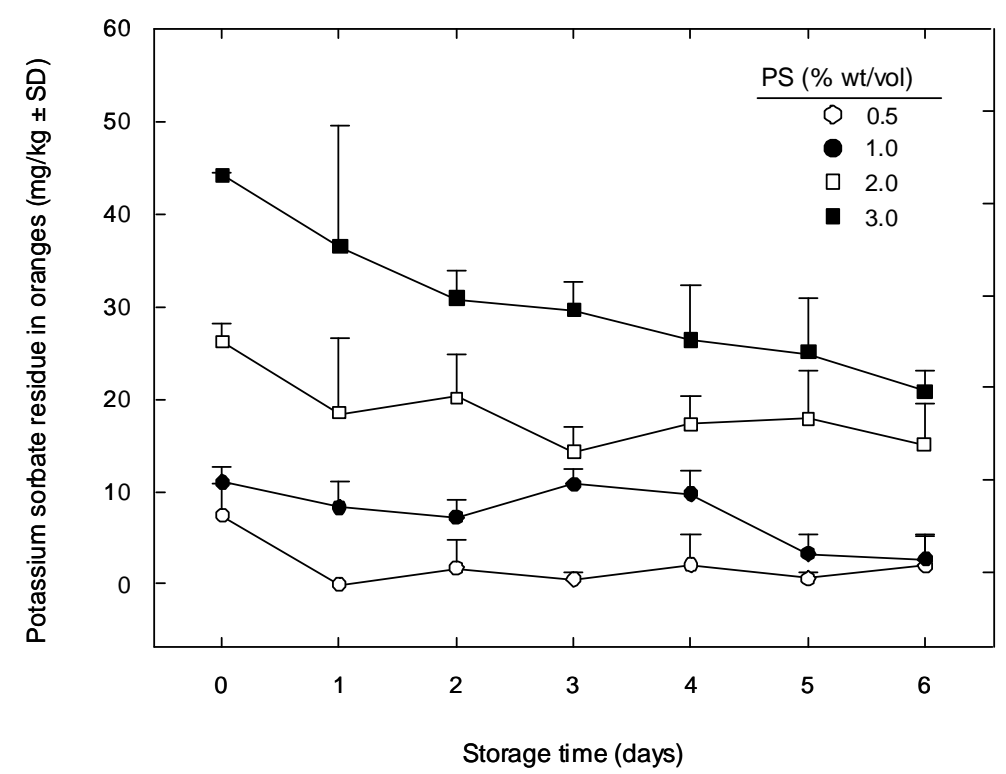

Figure 3. Influence of treatment concentration on potassium sorbate (PS) residue in oranges treated for $1 \mathrm{~min}$ at $25^{\circ} \mathrm{C}$ during the first 6 days of storage at $15{ }^{\circ} \mathrm{C}$. 


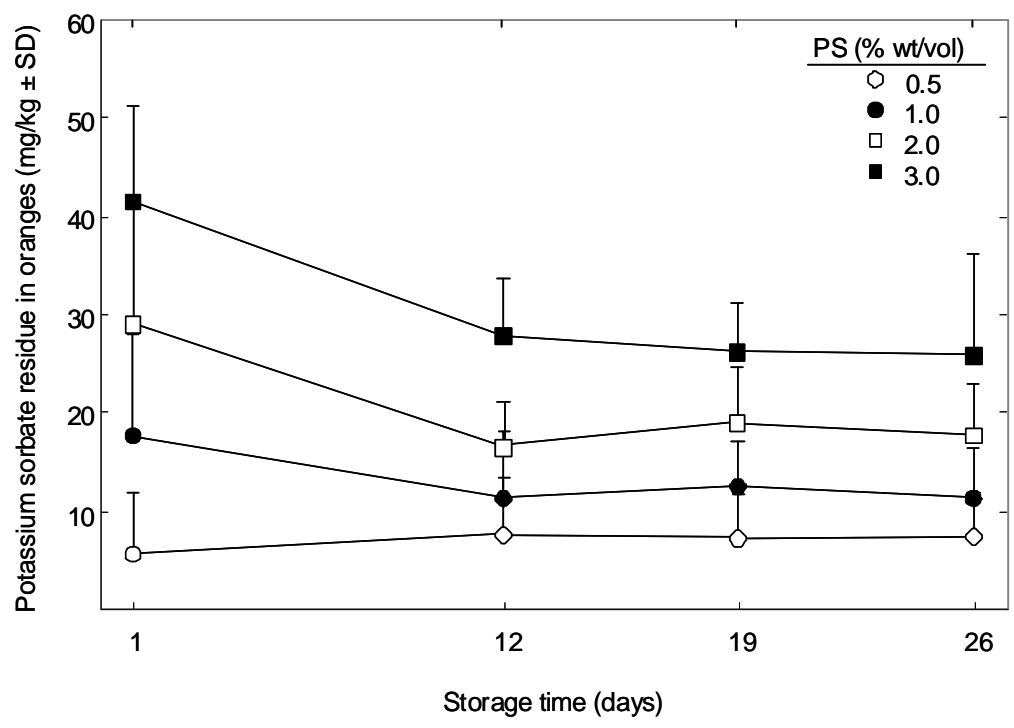

Figure 4. Influence of treatment concentration on potassium sorbate (PS) residue in oranges treated for $1 \mathrm{~min}$ at $25^{\circ} \mathrm{C}$ and stored at $15{ }^{\circ} \mathrm{C}$ for 26 days.

between day 0 and day 1 . No significant differences were found between the residue contents at day 6 (Figure 3) and day 12 (Figure 4), within fruit treated with the same potassium sorbate concentration. Residue contents also remained relatively unchanged during the rest of the 26days storage period (Figure 4). In our work, the residue content was proportional to the amount of potassium sorbate used in the treatment, this fact has also been observed in previous studies with other fungicides like fludioxonil (24), imazalil $(25-28)$, pyrimethanil $(28,29)$ or thiabendazole $(26,30)$. The level of residue declined to one-half the initial residue concentration after approximately 5 or 6 days (Figure 3). The decrease in the potassium sorbate residue content during the storage period could explain the loss of antifungal efficacy of potassium sorbate treatments against green and blue molds on citrus fruit observed when the incubation period of the treated fruit was prolonged $(7,8)$.

A simple, rapid, and accurate spectrophotometric method was used to determine residues of potassium sorbate in citrus fruit. The application of this method to quantify residue level after potassium sorbate treatments of citrus fruit showed the effect of different treatment parameters and subsequent handling on residue concentrations. Compared to an HPLC 
method, the spectrophotometric method is more convenient, easy, and rapid. Furthermore, knowledge of residue levels and their persistence is needed to intelligently employ the potassium sorbate treatments for disease control applications. In this work, potassium sorbate residues were analyzed based on blended whole fruit. Since Penicillium species strictly infect fruit through rind injuries, an interesting but more complex study may consider the efficacy of postharvest potassium sorbate treatments in relation to potassium sorbate residue levels in fruit wound sites. The amount of potassium sorbate residues in the fruit increases with the temperature and concentration of the treatment solution. A brief water rinse almost completely removed the residues of potassium sorbate when applied promptly after treatment. However, potassium sorbate migrated rapidly into the rind of fruit and the removal of residues was not complete even when a high-pressure water wash was used. Potassium sorbate residue levels in fruit decreased during storage to approximately one-half the initial residue concentration after 5 or 6 days, and then remained relatively constant. This decline in residues would explain why some workers reported that potassium sorbate effectiveness declined when citrus fruit were stored for longer periods. The mechanism of decline of potassium sorbate residues on fresh fruit is not known and warrants further study. In many processed products, potassium sorbate residues decline, sometimes rapidly (31). Other studies (32) reported that $\mathrm{pH}$ markedly influenced the rate of decline in potassium sorbate levels in model aqueous systems designed to simulate plastic packaging; at $\mathrm{pH}$ 3.5 , the decline was much more rapid than at $\mathrm{pH} 5$. Sorbates are also metabolized by humans (33) and many microorganisms (13).

\section{ACKNOWLEDGEMENTS}

We thank the Institut Valencià d'Investigacions Agràries (IVIA, Valencia, Spain) for funding the visit of Clara Montesinos to the San Joaquin Valley Agricultural Sciences Center in Parlier (California, USA). We also thank the California Citrus Research Board for partial financial support to conduct this research, John Maze of the University of California Lindcove Research and Extension Center (Exeter, California) for the use and operation of their pressure washer, and acknowledge Charlene Jewell (John Bean Technologies Corporation, Riverside, California) for suggesting this study. 


\section{LITERATURE CITED}

(1) Sofos, J. N.; Busta, F. F. Sorbic acid and sorbates. In: Antimicrobials in Foods, Second ed.; Davidson, P. M., Branen, A. L., Eds.; Marce Dekker, Inc.: New York, USA, 1993; pp. 49-94.

(2) Smoot, J. J.; McCornack, A. A. The use of potassium sorbate for citrus decay control. Proc. Fla. State Hort. Soc. 1978, 91, 119-122.

(3) Nelson, P. M.; Wheeler, R. W.; McDonald, P. D. Potassium sorbate in combination with benzimidazoles reduces resistant Penicillium digitatum decay in citrus. Proc. Int. Soc. Citriculture 1981, 2, 820823.

(4) Kitagawa, H.; Kawada, K. Effect of sorbic acid and potassium sorbate on the control of sour rot of citrus fruits. Proc. Fla. State Hort. Soc. 1984, 97, 133-135.

(5) Wild, B. L. Fungicidal activity of potassium sorbate against Penicillium digitatum as affected by thiabendazole and dip temperature. Scientia Hortic. 1987, 32, 41-48.

(6) Gutter, Y. Investigations on new postharvest fungicides: Israel. Proc. Int. Soc. Citriculture 1981, 2, 810-811.

(7) Palou, L.; Usall, J.; Smilanick, J. L.; Aguilar, M. J.; Viñas, I. Evaluation of food additives and low-toxicity compounds as alternative chemicals for the control of Penicillium digitatum and Penicillium italicum on citrus fruit. Pest Manag. Sci. 2002, 58, 459466.

(8) Montesinos-Herrero, C.; del Río, M. A.; Pastor, C.; Brunetti, O.; Palou, L. Evaluation of brief potassium sorbate dips to control postharvest penicillium decay on major citrus species and cultivars. Postharvest Biol. Technol. 2009, 52, 117-125.

(9) Smilanick, J. L.; Mansour, M.; Gabler, F. M.; Sorenson, D. Control of citrus postharvest green mold and sour rot by potassium sorbate combined with heat and fungicides. Postharvest Biol. Technol. 2008, 47, 226-238.

(10) Karabulut, O. A.; Romanazzi, G.; Smilanick, J. L.; Lichter, A. Postharvest ethanol and potassium sorbate treatments of table grapes to control gray mold. Postharvest Biol. Technol. 2005, 37, 129-134.

(11) Karabulut, O. A.; Lurie, S.; Droby, S. Evaluation of the use of sodium bicarbonate, potassium sorbate and yeast antagonists for 
decreasing postharvest decay of sweet cherries. Postharvest Biol. Technol. 2001, 23, 233-236.

(12) US EPA (United States Environmental Protection Agency). 40 CFR part $152.25(\mathrm{~g})$ - Exemptions for pesticides of a character not requiring FIFRA regulation. Final Rule. Fed. Reg. 1996, 61, 88788879 .

(13) Sofos, J. N. Interactions and synergistic effects. In Sorbate food preservatives; CRC Press, Inc.: Boca Raton, FL, USA, 1989; pp 5594.

(14) Alderton, G.; Lewis, J. C. Determination of sorbic acid and its disappearance from pickle brines. Food Res. 1958, 23, 338.

(15) Harrison, N. Determination of potassium sorbate in figs. Unpublished data. California Fig Growers and Packers, Fresno, California, USA; 1961.

(16) AOAC. Official Methods of Analysis, 12th ed; Association of Official Analytical Chemist; Washington, DC, USA, 1975.

(17) Park, G. L.; Nelson, D. B. HPLC analysis of sorbic acid in citrus fruit. J. Food Sci. 1981, 46, 1629-1631.

(18) Nury, F. S.; Bolin, H. R. Colorimetric assay for potassium sorbate in dried fruits. J. Food Sci. 1962, 27, 370-372.

(19) Rivero Molina, A.; Vereda Alonso, E.; Siles Cordero, M. T.; García de Torres, A.; Cano Pavón, J. M. Spectrophotometric flow-injection method for determination of sorbic acid in wines. Lab. Rob. Autom. 1999, 11, 299-303.

(20) Smilanick, J. L.; Margosan, D. A.; Gabler, F. M.; Usall, J.; Michael, I. F. Control of citrus green mold by carbonate and bicarbonate salts and the influence of commercial postharvest practices on their efficacy. Plant Dis. 1999, 83, 139-145.

(21) Smilanick, J. L.; Denis-Arrue, R. Control of green mold of lemons with Pseudomonas species. Plant Dis. 1992, 76, 481-485.

(22) Palou, L.; Smilanick, J. L.; Usall, J.; Viñas, I. Control of postharvest blue and green molds of oranges by hot water, sodium carbonate, and sodium bicarbonate. Plant Dis. 2001, 85, 371-376.

(23) Schirra, M.; D'hallewin, G. Storage performance of Fortune mandarins following hot water dips. Postharvest Biol. Technol. 1997, 10, 229-238. 
(24) Schirra, M.; D'Aquino, S.; Palma, A.; Marceddu, S.; Angioni, A.; Cabras, P.; Scherm, B.; Migueli, Q. Residue level, persistence, and storage performance of citrus fruit treated with fludioxonil. J. Agric. Food Chem. 2005, 53, 6718-6724.

(25) Smilanick, J. L.; Michael, I. F.; Mansour, M. F.; Mackey, B. E.; Margosan, D. A.; Flores, D.; Weist, C. F. Improved control of green mold of citrus fruit with imazalil in warm water compared with its use in wax. Plant Dis. 1997, 81, 1299-1304.

(26) Cabras, P.; Schirra, M.; Pirisi, F. M.; Garau, V. L.; Angioni, A. Factors affecting imazalil and thiabendazole uptake and persistence in citrus fruits following dip treatments. J. Agric. Food Chem. 1999, 47, 3352-3354.

(27) Schirra, M.; Cabras, P.; Angioni, A.; Melis, M. Residue level of imazalil fungicide in lemons following pre-storage dip treatment at 20 and $50^{\circ}$ C. J. Agric. Food Chem. 1996, 44, 2865-2869.

(28) D’Aquino, S.; Schirra, M.; Palma, A.; Angioni, A.; Cabras, P.; Migheli, Q. Residue levels and effectiveness of pyrimethanil versus imazalil when using heated postharvest dip treatments for control of Penicillium decay on citrus fruit. J. Agric. Food Chem. 2006, 54, 4721-4726.

(29) Smilanick, J. L.; Mansour, M. F.; Gabler, F. M.; Goodwine, W. R. The effectiveness of pyrimethanil to inhibit germination of Penicillium digitatum and to control citrus green mold after harvest. Postharvest Biol. Technol. 2006, 42, 75-85.

(30) Smilanick, J. L.; Mansour, M. F.; Sorenson, D. Pre- and postharvest treatments to control green mold of citrus fruit during ethylene degreening. Plant Dis. 2006, 90, 89-96.

(31) Campos, C. A.; Gerschenson, L. N. Effect of certain additives on sorbate stability. Food Res. Int. 1996, 29, 147-154.

(32) Castro, M. P.; Gerschenson, L. N.; Campos, C. A. Stability of sorbates in the presence of EDTA: effect of $\mathrm{pH}$, packaging material and sequestrant level. J. Sci. Food Agric. 2005, 85, 328-332.

(33) Deuel, H. J. Jr.; Calbert, C. E.; Anisfeld, L.; McKeehan, H.; Blunden, H. Sorbic acid as a fungistatic agent for foods. II. Metabolism of $\beta$-unsaturated fatty acids with emphasis on sorbic acid. Food Res. 1954, 19, 13-19. 
Chapter 4

\section{Short exposure to high $\mathrm{CO}_{2}$ and $\mathrm{O}_{2}$ at curing temperature to control postharvest diseases of citrus fruits}

CLARA MONTESINOS-HERRERO, MIGUEL ÁNGEL DEL RÍO, CRISTINA ROJAS-ARGUDO and LLUÍS PALOU

Laboratori de Patologia, Centre de Tecnologia Postcollita (CTP) Institut Valencià d'Investigacions Agràries (IVIA) Apartat Oficial, 46113 Montcada, València, Spain

Reference: Plant Disease 2012, 96, 423-430. 



\begin{abstract}
Curing of citrus fruits at 30 to $37^{\circ} \mathrm{C}$ and 90 to $98 \%$ relative humidity for 65 to $72 \mathrm{~h}$ is an effective alternative to fungicides to control postharvest green and blue molds, caused by Penicillium digitatum and P. italicum, respectively. However, commercial adoption is limited because treatment is long and it may harm fruit quality. In order to improve the feasibility of curing, short $\mathrm{CO}_{2}$ or $\mathrm{O}_{2}$ exposures at curing temperature were evaluated on 'Nadorcott', 'Clemenules' and 'Ortanique' mandarins, and 'Valencia' oranges. Fruit were artificially inoculated, exposed $24 \mathrm{~h}$ later to air (control), 15, 30, 50, or $95 \mathrm{kPa} \mathrm{CO}$, or 30 or $45 \mathrm{kPa} \mathrm{O}_{2}$, at 20 or $33^{\circ} \mathrm{C}$ for 8,24 , or $48 \mathrm{~h}$, and incubated at $20^{\circ} \mathrm{C}$ for 4,7 , or 15 days. Exposure at $33^{\circ} \mathrm{C}$ with $15 \mathrm{kPa} \mathrm{CO}$ for $24 \mathrm{~h}$ or $30 \mathrm{kPa} \mathrm{O}_{2}$ for $48 \mathrm{~h}$ effectively controlled both green and blue molds after 7 days of incubation at $20^{\circ} \mathrm{C}$, but control of both diseases was minimal after 15 days. To assess potential induction of disease resistance, fruit were treated as described above, then inoculated after 1,2 , or 5 days at $20^{\circ} \mathrm{C}$ and evaluated after 3 and 6 more days at $20^{\circ} \mathrm{C}$. All of the treatments were ineffective in inducing fruit resistance. Short exposures of citrus fruit to high $\mathrm{CO}_{2}$ or $\mathrm{O}_{2}$ at curing temperatures may be part of a control program alternative to synthetic fungicides, especially for organic fruit markets.
\end{abstract}

\title{
INTRODUCTION
}

Fungicides such as imazalil, sodium ortho-phenylphenate, or thiabendazole have been widely used for treatment of citrus fruit against postharvest diseases. Green and blue molds caused by Penicillium digitatum (Pers.:Fr.) Sacc. and Penicillium italicum Wehmer, respectively, cause the majority of economic losses during storage and marketing of citrus fruits (13). The number of synthetic postharvest fungicides is declining because of their reduced effectiveness due to the proliferation of fungicide resistant isolates of decay pathogens and concerns about human and environmental safety of their residues. Since the control of postharvest diseases is an imperative for the marketing of citrus fruit, new and nontoxic methods are required to substitute or complement the current use of synthetic fungicides (25). 
Studies to find alternatives to conventional fungicides have quantified the effect of heat on postharvest treatments of fruit $(26,28,38)$. Heat treatments have a direct effect on reducing the effective inoculum size by inactivating or killing spores, and an indirect effect via physiological responses of the fruit tissue that inhibit fungal development (38). Curing is a heat treatment that consists of holding the fruit at 30 to $37^{\circ} \mathrm{C}$ and 90 to $98 \%$ relative humidity (RH) for 65 to $72 \mathrm{~h}$. Methods based on curing treatments have been evaluated to control green and/or blue molds on citrus fruits $(6,7,22,30,47)$. For instance, curing at $33^{\circ} \mathrm{C}$ and high $\mathrm{RH}$ for $65 \mathrm{~h}$ has been reported as an effective method to control green mold on oranges (30). Moreover, curing at $36^{\circ} \mathrm{C}$ for $72 \mathrm{~h}$ reduced chilling injury on 'Star Ruby' grapefruit (32). Although effective, its use commercially is inconvenient because it is time consuming, requires energy for heating, and may harm fruit quality. Nevertheless, while the use of curing as a standalone method is not feasible, some modifications of the method and the combination with other treatments may overcome the drawbacks of curing alone. In this regard, short exposures to modified atmospheres created by elevating the concentration of $\mathrm{CO}_{2}$ or $\mathrm{O}_{2}$ may be complementary with curing. Exposure to $\mathrm{CO}_{2}$-enriched atmospheres has been reported to provide fungistatic effects and, in some cases, induce resistance in fresh fruit against major postharvest diseases $(16,28,33)$. Cold storage in high $\mathrm{CO}_{2}$ atmospheres is a common commercial practice with some commodities and suppression of decay has been widely assessed $(2,5,39,45)$. According to El-Goorani and Sommer (14), the $\mathrm{CO}_{2}$ concentrations required to inhibit growth and/or spore germination vary with fungal species, but $\mathrm{CO}_{2}$ levels above $10 \%$ are generally needed to significantly suppress fungal growth. However, very few studies have tested the effect of short-term exposures to high levels of $\mathrm{CO}_{2}$ on postharvest diseases of fresh produce. Exposure of harvested avocados to $30 \% \mathrm{CO}_{2}$ for $24 \mathrm{~h}$ at 20 to $25^{\circ} \mathrm{C}$ delayed the development of anthracnose, caused by Colletotrichum gloeosporioides (33). Furthermore, table grapes pretreated with $20 \mathrm{kPa} \mathrm{CO}$ for 3 days at $0^{\circ} \mathrm{C}$ had less natural decay during subsequent cold storage (37). On the other hand, superatmospheric $\mathrm{O}_{2}$ has been shown to prevent growth of microbes in some fruit and vegetable crops during cold storage $(1,40)$, and specifically, inhibit the development of fungal diseases $(19,44,48,49)$. Moreover, high $\mathrm{O}_{2}$ atmospheres may be advantageous for product quality 
$(11,48)$ and prevent anaerobic fermentation and off-flavor development $(1,41)$. Nevertheless, the levels of $\mathrm{O}_{2}$ that were most effective for decay control were those close to $80 \%$ or higher, which could be difficult and expensive to maintain on a large scale, as well as a fire hazard in a commercial situation.

Although controlled or modified atmospheres are commonly used for the storage or packaging of some commodities, this technology has not been used in citrus production because the potential benefits do not compensate for the high costs (18). Therefore, there is a lack of information about the effects of altered concentrations of $\mathrm{CO}_{2}$ or $\mathrm{O}_{2}$ on the control of decay in citrus fruit, especially in the case of exposure for short periods at high temperatures. Presumably, by using an atmosphere that inhibits fungal growth, curing time could be reduced preserving fruit quality and maintaining antifungal effectiveness. In the present study, exposure of several citrus fruit cultivars to high $\mathrm{CO}_{2}$ or $\mathrm{O}_{2}$ treatments during short periods at curing temperature was evaluated as a method to either control established infections of $P$. digitatum or $P$. italicum, or induce physical and/or biochemical changes in the fruit that could maintain or increase its resistance to infection. Some preliminary results have been presented $(24,29)$.

\section{MATERIALS AND METHODS}

Fruit. Fruit used in these experiments were oranges (Citrus sinensis (L.) Osbeck) cv. Valencia, clementine mandarins (C. reticulata Blanco) cv. Clemenules (synonyms: 'Nules', 'Clementina de Nules'), and hybrid mandarins cvs. Nadorcott $(C$. reticulata $\times C$. sinensis) (synonyms: 'Afourer', 'W. Murcott') and Ortanique [Citrus reticulata $\times(C$. sinensis $\times$ C. reticulata)] from commercial orchards in Valencia (Spain). Fruit had not been treated with fungicides nor artificially coated. The fruit were stored at $5^{\circ} \mathrm{C}$ and $90 \% \mathrm{RH}$ until their use in the experiments within the next week. Prior to each assay, the fruit were selected, randomized, rinsed with fresh water, and allowed to air dry at room temperature.

Inoculum. Isolates NAV-7 of $P$. digitatum and MAV-1 of $P$. italicum used in the experiments are included in the fungal culture collection of the Pathology Laboratory of the Postharvest Technology Center of the Institut Valencià d'Investigacions Agràries (IVIA). They had been 
obtained from decayed oranges or mandarins from the Valencia area, purified, identified, and selected for their pathogenicity and aggressiveness among a high amount of autochthonous isolates. The two pathogens were cultured on potato dextrose agar (PDA) in petri dishes at $25^{\circ} \mathrm{C}$ for 7 to 14 days. Conidial suspensions of the pathogens were prepared in sterile water with Tween $80(0.05 \% \mathrm{w} / \mathrm{v})$ and adjusted to a concentration of $10^{5}$ or $10^{6}$ spores $/ \mathrm{ml}$ after counting spores with a hemacytometer. Fruit were inoculated with $P$. digitatum by immersing a stainless steel rod with a probe tip 1-mm wide and 2-mm long into the required spore suspension and then wounding each fruit with this inoculum-carrying tip once in the equator. The opposite side of the same fruit was inoculated with $P$. italicum using the same procedure.

Gas exposure. Chambers used for gas exposure consisted of hermetically sealed, transparent polymethyl methacrylate cabinets $(82 \times$ $62 \times 87 \mathrm{~cm}$ ) fitted with outlet and inlet ports through which $\mathrm{O}_{2}$ or $\mathrm{CO}_{2}$ (Alphagaz, Air Liquide España S.A., Madrid, Spain) were injected until the desired concentrations of $\mathrm{O}_{2}(30$ or $45 \mathrm{kPa})$ or $\mathrm{CO}_{2}(15,30,50$, or 95 $\mathrm{kPa}$ ) were achieved. The cabinets were also fitted with internal basal water trays that allowed achieving a high RH $(95 \pm 5 \%)$. Levels of $\mathrm{O}_{2}$, $\mathrm{CO}_{2}$, temperature, and $\mathrm{RH}$ were continuously monitored by means of the computer-controlled system (Control-Tec ${ }^{\circledR}$, Tecnidex S.A., Paterna, Valencia, Spain). This system activated the injection of $\mathrm{O}_{2}$ or $\mathrm{CO}_{2}$ when the concentration of the gases was below the settings and stopped when the target level was measured, with an oscillation of approximately \pm 2 $\mathrm{kPa} \mathrm{O}_{2}$ or $\mathrm{CO}_{2}$. Depending on the experiment, the treatment duration was 8,24 , or $48 \mathrm{~h}$. Cabinets were installed in the postharvest research facilities of the IVIA in a $40 \mathrm{~m}^{3}$ standard cold storage/curing room that was set to each experimental temperature $\left(20\right.$ or $\left.33^{\circ} \mathrm{C}\right)$. A curing treatment of $33^{\circ} \mathrm{C}$ was selected because it is the lowest temperature that has been reported to be effective for the control of citrus green and blue molds (30). Not all the combinations of treatment conditions were tested on all cultivars; treatments that provided better disease-control responses were selected for further tests with the same or other citrus cultivars. The treatments applied to different cultivars are listed in Table 1. 
Table 1. Summary of the gas treatments applied on mandarins and oranges.

\begin{tabular}{|c|c|c|c|c|c|}
\hline \multirow{2}{*}{ Fruit } & \multicolumn{4}{|c|}{ Treatments $^{a}$} & \multirow{2}{*}{$\begin{array}{l}\text { Incubation time } \\
\text { at } 20^{\circ} \mathrm{C} \text { (days) }\end{array}$} \\
\hline & Gas & Concentration $(\mathrm{kPa})$ & Temperature $\left({ }^{\circ} \mathrm{C}\right)$ & Time (h) & \\
\hline \multirow{6}{*}{$\begin{array}{l}\text { 'Ortanique' } \\
\text { mandarins }\end{array}$} & Air & & 20,33 & 8,24 & 14 \\
\hline & $\mathrm{CO}_{2}$ & $15,30,50$ & 20,33 & 8,24 & 7 \\
\hline & $\mathrm{CO}_{2}$ & 95 & 20 & 8,24 & 7 \\
\hline & $\mathrm{CO}_{2}$ & 95 & 33 & 24 & 7 \\
\hline & $\mathrm{O}_{2}$ & 30,45 & 20,33 & 8,24 & 7 \\
\hline & $\mathrm{O}_{2}$ & 30 & 33 & 24,48 & 14 \\
\hline \multirow{4}{*}{$\begin{array}{l}\text { 'Nadorcott' } \\
\text { mandarins }\end{array}$} & Air & & 20,33 & 8,24 & 7 \\
\hline & $\mathrm{CO}_{2}$ & $15,30,50$ & 20,33 & 8,24 & 7 \\
\hline & $\mathrm{CO}_{2}$ & 95 & 33 & 8,24 & 7 \\
\hline & $\mathrm{N}_{2}$ & 95 & 33 & 8,24 & 7 \\
\hline \multirow{3}{*}{$\begin{array}{l}\text { 'Clemenules' } \\
\text { mandarins }\end{array}$} & Air & & 33 & 24,48 & 14 \\
\hline & $\mathrm{O}_{2}$ & 30 & 20 & 48 & 14 \\
\hline & $\mathrm{O}_{2}$ & 30 & 33 & 24,48 & 14 \\
\hline \multirow{3}{*}{$\begin{array}{l}\text { 'Valencia' } \\
\text { oranges }\end{array}$} & Air & & 33 & 24,48 & 15 \\
\hline & $\mathrm{O}_{2}$ & 30 & 33 & 48 & 15 \\
\hline & $\mathrm{CO}_{2}$ & 15 & 33 & 24 & 15 \\
\hline
\end{tabular}

${ }^{a}$ Air treatments were used as controls. RH was $95 \pm 5 \%$ during treatments and $85 \pm 5 \%$ during incubation.

Effect on green and blue molds. Fruit were inoculated with a suspension of $10^{6}$ spores $/ \mathrm{ml}$ of $P$. digitatum and $P$. italicum and kept at $20^{\circ} \mathrm{C}$ for $24 \mathrm{~h}$ before treatment. This inoculum density is recommended for evaluation of curative postharvest treatments to control green and blue molds (11). Fruit were then placed in the gas cabinets and treated according to the specifications for each experiment (Table 1). Treated fruit were arranged in plastic trays and incubated at $20^{\circ} \mathrm{C}$ and $85 \pm 5 \%$ $\mathrm{RH}$. Green mold incidence (number of decayed fruit) was recorded after $4,7,14$, or 15 days of incubation, depending on the experiment. Disease incidence is the most important parameter to evaluate the efficacy of treatments, but severity (lesion diameter) and sporulation (percentage of sporulated lesions) were also measured at the same time to be able to detect more subtle differences between treatments in case disease incidences were similar. Fruit treated with air at $20^{\circ} \mathrm{C}$ were considered as 
controls. Each treatment was applied to three replicates each with 25 fruit.

Induced resistance to green mold. Noninoculated citrus fruit from the same four cultivars were treated as described above, stored at $20^{\circ} \mathrm{C}$ for 1 , 2 , or 5 days and subsequently inoculated with $P$. digitatum at a concentration of $10^{5}$ spores $/ \mathrm{ml}$. The incidence, severity, and sporulation of green mold were evaluated after 3 and 6 days of incubation at $20^{\circ} \mathrm{C}$. Each treatment was applied to three replicates each with 12 fruit.

Statistical analysis. Data from countings (disease incidence and pathogen sporulation) was arcsine transformed. The percentage of disease reduction with respect to the control treatments was calculated. Multifactor analyses of variance (ANOVA) were performed for each evaluation date (after 4 to 15 days at $20^{\circ} \mathrm{C}$ ) using Statgraphics Plus 4.1 (Manugistics, Inc., Rockville, MD) with disease incidence, reduction, and severity, and pathogen sporulation as dependent variables and gas treatment composition, temperature, and/or time of exposure as factors, depending on the experiment. ANOVAs for different levels of the factors were performed because of significant interactions. Where appropriate, means were separated by Fisher's Protected LSD test $(P=0.05)$. When exposure to high $\mathrm{CO}_{2}$ or $\mathrm{O}_{2}$ was tested both at 20 and $33^{\circ} \mathrm{C}$, Limpel's formula (34) was applied to determine if the effectiveness of the combination of curing temperature and high $\mathrm{CO}_{2}$ or $\mathrm{O}_{2}$ was synergistic.

\section{RESULTS}

On Nadorcott mandarins treated with high $\mathrm{CO}_{2}$ at $20^{\circ} \mathrm{C}$, disease reduction was not significant regardless of gas composition and treatment duration (data not shown). When applied at $33^{\circ} \mathrm{C}$ for $8 \mathrm{~h}$, the reduction in the incidence of green and blue molds was lower than 10 and $40 \%$, respectively, after 4 days of incubation at $20^{\circ} \mathrm{C}$. In contrast, $\mathrm{CO}_{2}$ treatments at $33^{\circ} \mathrm{C}$ for $24 \mathrm{~h}$ greatly reduced green and blue molds incidence after 4 days compared to air-treated fruit (Fig. 1). However, reductions were very low after 7 days of incubation, when $100 \%$ of control fruit (exposed to air at $20^{\circ} \mathrm{C}$ for $8 \mathrm{~h}$ ) was decayed. In general, most of the tested $\mathrm{CO}_{2}$ concentrations showed a similar ability to control the diseases. Green mold reduction significantly differed from 55\% (50 
$\left.\mathrm{kPa} \mathrm{CO}_{2}\right)$ to $80 \%\left(15 \mathrm{kPa} \mathrm{CO}_{2}\right)$, but it was statistically similar and intermediate on mandarins treated with the rest of $\mathrm{CO}_{2}$ concentrations. Blue mold reduction reached $99 \%$ after exposure to $95 \mathrm{kPa} \mathrm{CO}_{2}$ at the 4 days of incubation, and results for the rest of $\mathrm{CO}_{2}$ treatments were statistically similar. High levels of $\mathrm{N}_{2}(95 \mathrm{kPa})$ applied to Nadorcott mandarins at $33^{\circ} \mathrm{C}$ for 8 or $24 \mathrm{~h}$ only reduced the incidence of green and blue molds by 5 and $40 \%$, respectively. In virtually all cases, the combination of curing temperature and high $\mathrm{CO}_{2}$ or $\mathrm{O}_{2}$ was synergistic according to Limpel's formula (Fig. 1).

Exposure of Ortanique mandarins to high $\mathrm{CO}_{2}$ or 30 or $45 \mathrm{kPa} \mathrm{O}$ for 8 or $24 \mathrm{~h}$ at $20^{\circ} \mathrm{C}$ did not significantly controlled blue mold (data not shown). At $20^{\circ} \mathrm{C}$, green mold was significantly reduced only by $95 \mathrm{kPa}$ $\mathrm{CO}_{2}$ (Fig. 2). However, these treatments applied at $33^{\circ} \mathrm{C}$ effectively controlled both molds (Fig. 2). The average green mold reduction after 4 days of incubation was 71,70 , and $60 \%$, and 81,87 , and $92 \%$ for 8 - and 24-h exposure to 50, 30, and $15 \mathrm{kPa} \mathrm{CO}$, respectively. Among these values, only those for the $15 \mathrm{kPa} \mathrm{CO}_{2}$ treatment were statistically different. The effectiveness declined after 7 days of incubation, but Ortanique mandarins treated with $15 \mathrm{kPa} \mathrm{CO}$ still had $74 \%$ less green mold incidence than control fruit (100\% disease incidence). Exposure of Ortanique mandarins to 30 or $45 \mathrm{kPa} \mathrm{O}_{2}$ at $33^{\circ} \mathrm{C}$ for $8 \mathrm{~h}$ marginally controlled green and blue molds after 4 days of incubation at $20^{\circ} \mathrm{C}$, while exposure for $24 \mathrm{~h}$ totally controlled both diseases. Once more, the effectiveness declined after 7 days. Nonetheless, when the treatment with $30 \mathrm{kPa} \mathrm{O}_{2}$ was extended to $48 \mathrm{~h}$, the incidence reductions of green and blue molds after 7 days of incubation were 96 and 92\%, respectively (Fig. 2), although dropped to 24 and 8\%, respectively, after 14 days (data not shown). Again, the application of high temperature with high $\mathrm{CO}_{2}$ or $\mathrm{O}_{2}$ was synergistic in most of the cases according to Limpel's formula. 


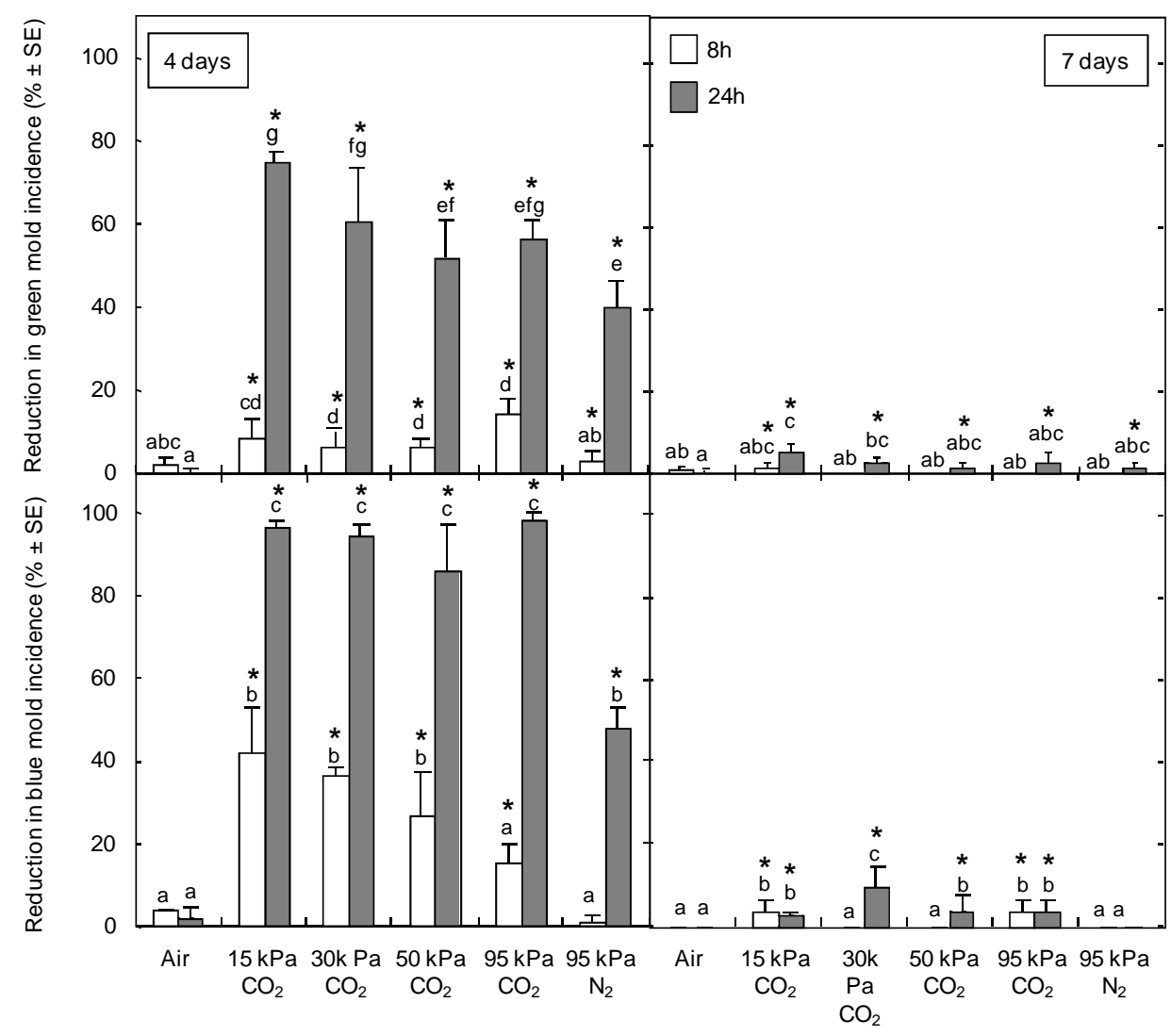

Fig. 1. Reduction in green and blue molds incidence with respect to the control treatment (air at $20^{\circ} \mathrm{C}$ for $8 \mathrm{~h} ; 100 \%$ incidence of both molds after 7 days of incubation) on Nadorcott mandarins artificially inoculated with Penicillium digitatum and $P$. italicum, treated $24 \mathrm{~h}$ later with air, 15, 30, 50 , or $95 \mathrm{kPa} \mathrm{CO}_{2}$ or $95 \mathrm{kPa} \mathrm{N}$ at $33^{\circ} \mathrm{C}$ for 8 or $24 \mathrm{~h}$, and incubated at $20^{\circ} \mathrm{C}$ for 4 and 7 days. For each individual graph, values within columns with the same letters did not differ significantly according to Fisher's protected LSD test $(P<0.05)$. Asterisk indicates synergistic activity was present between temperature and gas treatment according to Limpel's formula. 


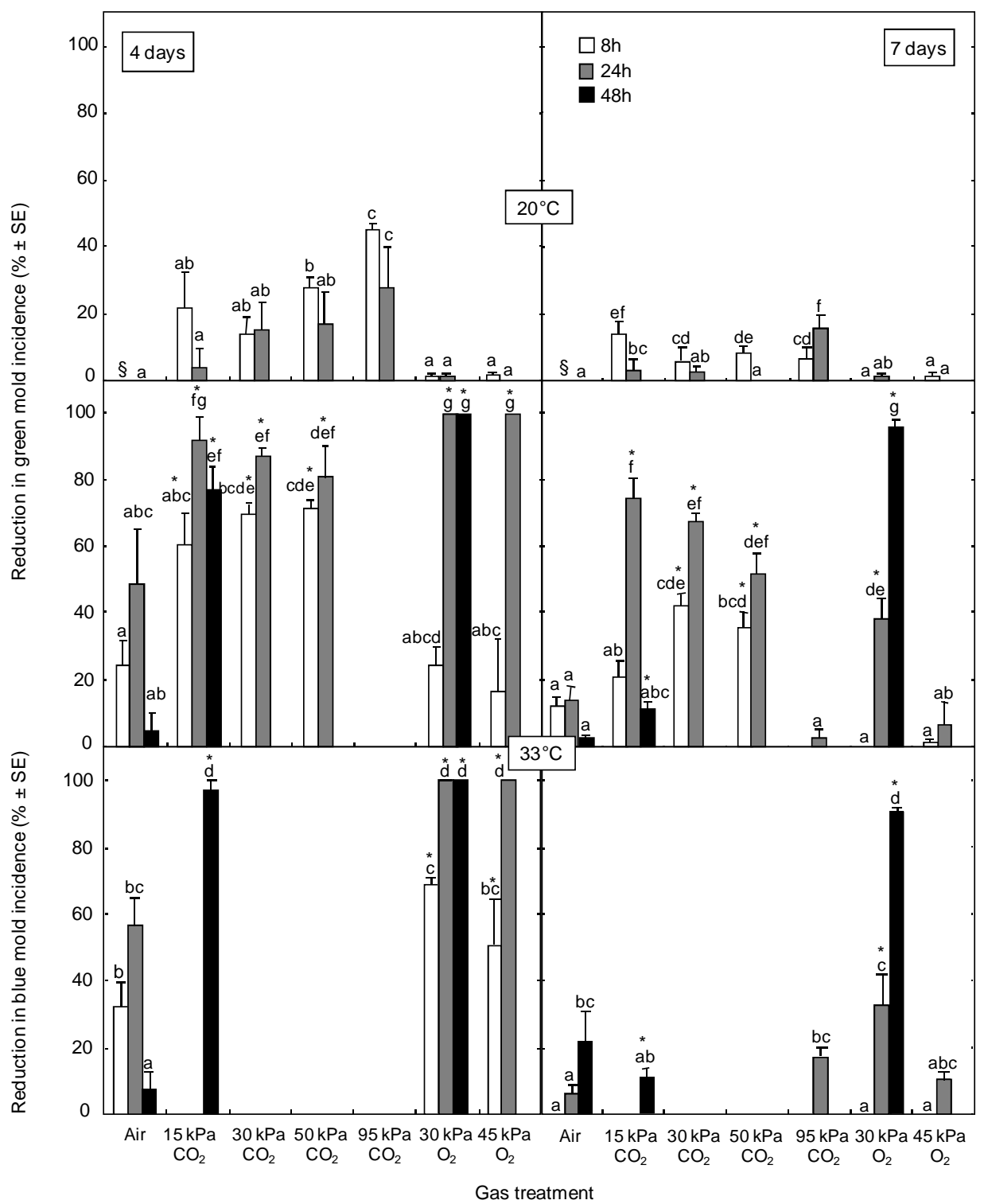

Fig. 2. Reduction in green and blue molds incidence with respect to the control treatment $\left(\S\right.$, air at $20^{\circ} \mathrm{C}$ for $8 \mathrm{~h} ; 100 \%$ incidence of both molds after 7 days of incubation) on Ortanique mandarins artificially inoculated with Penicillium digitatum and $P$. italicum, respectively, treated $24 \mathrm{~h}$ later with air, $15,30,50$, or $95 \mathrm{kPa} \mathrm{CO}_{2}$ or 30 or $45 \mathrm{kPa} \mathrm{O}_{2}$ at 20 or $33^{\circ} \mathrm{C}$ for 8,24 , or $48 \mathrm{~h}$, and incubated at $20^{\circ} \mathrm{C}$ for 4 and 7 days. For each 
individual graph, values within columns with the same letters did not differ significantly according to Fisher's protected LSD test $(P<0.05)$. Where no letters are shown, treatment conditions were not tested or readings were not performed. Asterisk indicates synergistic activity was present between temperature and gas treatment according to Limpel's formula.

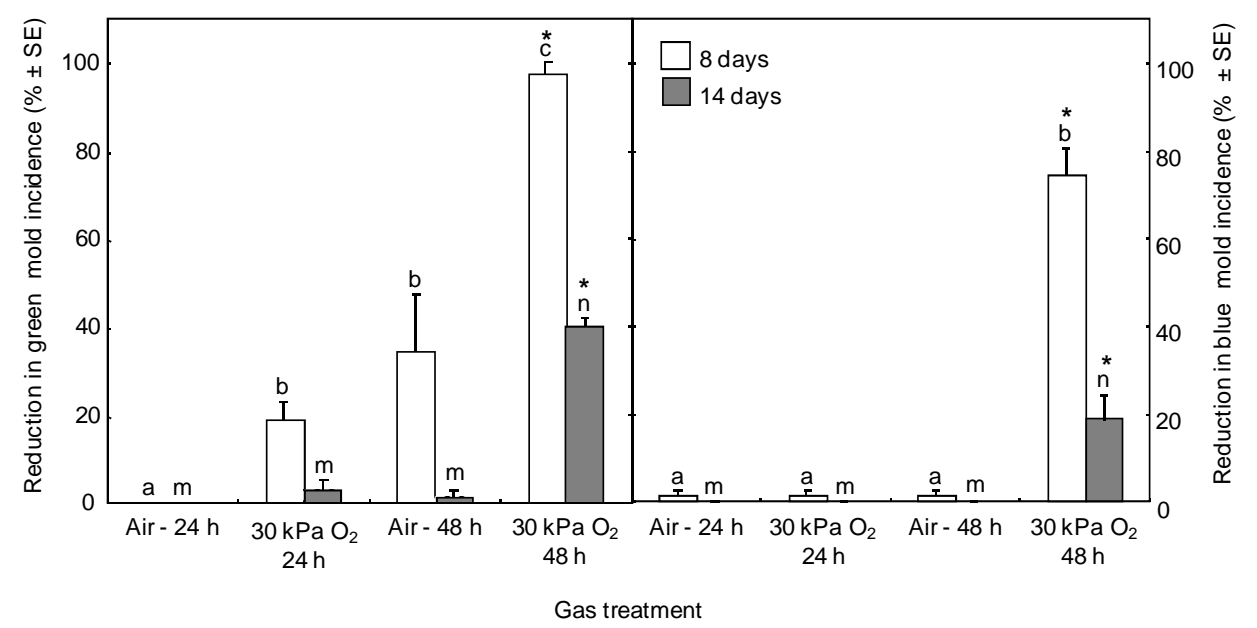

Fig. 3. Reduction in green and blue molds incidence with respect to the control treatment (air at $20^{\circ} \mathrm{C}$ for $24 \mathrm{~h} ; 99$ and $100 \%$ incidence of green and blue molds, respectively, after 7 days of incubation) on Clemenules mandarins artificially inoculated with Penicillium digitatum and $P$. italicum, respectively, treated $24 \mathrm{~h}$ later with air or $30 \mathrm{kPa} \mathrm{O}_{2}$ at $33^{\circ} \mathrm{C}$ for 24 or $48 \mathrm{~h}$, and incubated at $20^{\circ} \mathrm{C}$ for 8 and 14 days. For each individual graph, values within columns with the same letters ('a-c', and 'm-n' for 8 and 14 days, respectively) did not differ significantly according to Fisher's protected LSD test $(P<0.05)$. Asterisk indicates synergistic activity was present between temperature and gas treatment according to Limpel's formula. 


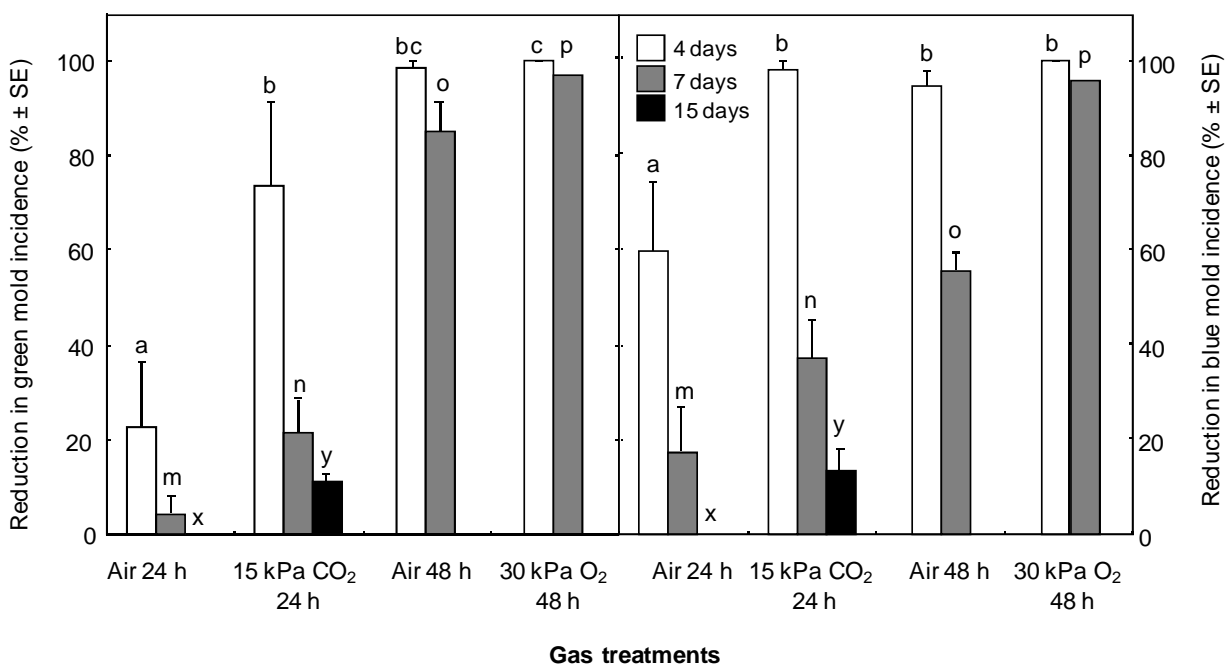

Fig. 4. Reduction in green and blue molds incidence with respect to the control treatment (air at $20^{\circ} \mathrm{C}$ for $24 \mathrm{~h} ; 100 \%$ incidence of both molds after 7 days of incubation) on Valencia oranges artificially inoculated with Penicillium digitatum and $P$. italicum, treated $24 \mathrm{~h}$ later at $33^{\circ} \mathrm{C}$ with air, $15 \mathrm{kPa} \mathrm{CO}$ for $24 \mathrm{~h}$, or $30 \mathrm{kPa} \mathrm{O}_{2}$ for $48 \mathrm{~h}$, and incubated at $20^{\circ} \mathrm{C}$ for 4,7 , and 15 days. For each individual graph, values within columns with the same letters ('a-c', 'm-p', and ' $x-y$ ' for 4, 7, and 15 days, respectively) did not differ significantly according to Fisher's protected LSD test $(P<0.05)$. Where no letters are shown, treatment conditions were not tested.

After 8 days of incubation at $20^{\circ} \mathrm{C}$, the incidence of green and blue mold on Clemenules mandarins exposed to $30 \mathrm{kPa} \mathrm{O}_{2}$ at $33^{\circ} \mathrm{C}$ for $24 \mathrm{~h}$ was significantly lower than that on air-treated or control mandarins (100\% disease incidence), but the reduction was poor and no reduction was observed in the case of blue mold (Fig. 3). However, extending the treatment time to a period of $48 \mathrm{~h}$ resulted in green and blue mold incidence reductions of 97 and $74 \%$ after 8 days of incubation, and 40 
and $20 \%$ after 14 days, respectively. When high $\mathrm{O}_{2}$ treatments for $48 \mathrm{~h}$ were tested at $20^{\circ} \mathrm{C}$, no significant reduction in both molds was obtained (data not shown). A synergistic effect was observed with the combination of curing temperature and high $\mathrm{O}_{2}$ according to Limpel's formula (Fig. $3)$.

After 4 days of incubation at $20^{\circ} \mathrm{C}$, treatments with $15 \mathrm{kPa} \mathrm{CO}_{2}$ at $33^{\circ} \mathrm{C}$ for $24 \mathrm{~h}$ reduced the incidence of green and blue molds on Valencia oranges by 74 and $98 \%$, respectively (Fig. 4). However, after 7 days of incubation, with $100 \%$ decay on control fruit, reduction in green and blue molds incidence dropped to 20 and $35 \%$, respectively. The incidence reductions on cured (air-treated) oranges subjected to the same incubation conditions were significantly lower. Extending fruit exposure to air at $33^{\circ} \mathrm{C}$ from 24 to $48 \mathrm{~h}$ reduced the incidence of green mold by more than 95 and $85 \%$ after 4 and 7 days of incubation, respectively, but blue mold incidence was 55\% lower than on control fruit after 7 days. Exposing oranges to $30 \mathrm{kPa} \mathrm{O}_{2}$ for this period of time reduced both diseases by 100 and $95 \%$ after 4 and 7 days of incubation, respectively. Treatments at $20^{\circ} \mathrm{C}$ were not performed with Valencia oranges (Table 1).

In general, data on disease severity followed similar trends to that of disease incidence. Lesion diameter was significantly reduced by high $\mathrm{CO}_{2}$ or $\mathrm{O}_{2}$ applied at $33^{\circ} \mathrm{C}$ for 24 or $48 \mathrm{~h}$ after 4 days of incubation at $20^{\circ} \mathrm{C}$, but the reduction considerably decreased after 7 or more days of incubation. Treatments applied at $20^{\circ} \mathrm{C}$ and/or for $8 \mathrm{~h}$ did not influence severity (data not shown). Similarly, the sporulation of $P$. digitatum and $P$. italicum was significantly inhibited by gas treatments at curing temperature during the first 4 or 7 days of incubation at $20^{\circ} \mathrm{C}$ in an air environment, but in general the inhibitory effect did not persist. The most important effect of the treatments on pathogen sporulation was observed in Valencia oranges, in which, for instance, exposure to $15 \mathrm{kPa} \mathrm{CO}_{2}$ at $33^{\circ} \mathrm{C}$ for $24 \mathrm{~h}$ reduced the sporulation of green and blue molds by 81 and $70 \%$, respectively, after 7 days of incubation, and 43 and $24 \%$, respectively, after 14 days (data not shown).Based on the disease incidence and severity data, none of the treatments induced resistance to the pathogens when applied before inoculation of fruit, regardless of cultivar, treatment conditions, and time between treatment and inoculation (data not shown). 


\section{DISCUSSION}

In this study, artificially inoculated citrus fruits treated at a curing temperature with $\mathrm{CO}_{2}$ or $\mathrm{O}_{2}$ at high concentrations showed lower green and blue molds incidence than those treated by curing in air alone, regardless of cultivar and length of treatment. In studies using conventional curing treatments in which citrus diseases were effectively controlled, fruit were held for 3 days at up to 36 to $37^{\circ} \mathrm{C}(4,22)$. However, these exposure conditions may adversely affect weight loss, rind color, taste, and flavor of fruit (38). Curing at milder conditions of $33^{\circ} \mathrm{C}$ for 72 , 65 , or even $48 \mathrm{~h}$ controlled in some cases green and blue molds on inoculated 'Navelina' or 'Salustiana' oranges (30). Similar results were observed in our study after curing Valencia oranges for $48 \mathrm{~h}$, but none of the other cultivars treated with air at $33^{\circ} \mathrm{C}$ and high $\mathrm{RH}$ for $48 \mathrm{~h}$ or briefer periods were protected by this treatment against the inoculated pathogens. Thus, we found an evident effect of the fruit variety on the efficacy of the treatments. The mode of action of heat in general $(26,28,38)$, and curing treatments in particular $(6,7,22,30,47)$, as methods to control postharvest diseases of citrus fruits has been extensively discussed. Heat treatments may induce several changes in the nucleus and cell wall of fungi, destroy their mitochondria and vacuoles, and cause loss of spore cytoplasm (3). In addition to these direct effects on fungi, indirect effects of heat on the interaction between fruit and pathogen have been described. Heat can induce biosynthesis of lignin or lignin-like polymers in injured fruit rind, which may act as a physical barrier to hyphae penetration (6), and the production of antifungal compounds (phytoalexins such as scoparone or pathogen-related proteins such as chitinase or $\beta$-1,3-gluconase) in response to pathogen infection $(21,38)$. Furthermore, some studies suggest that proteins biosynthesized by fruit to prevent denaturalization by heat (heat shock proteins), or melting of natural rind waxes, that would close potential infection sites, could act as defense mechanisms against molds (38). These indirect effects are dependent on fruit species and cultivar and also on fruit physical and physiological condition. This may be the reason why, in the present study, the same treatments with air at $33^{\circ} \mathrm{C}$ applied on different citrus fruit cultivars resulted in different degrees of decay inhibition: lack of control on Nadorcott and Clemenules mandarins and reductions of up to $50 \%$ on Ortanique hybrids. 
Treatments applied at the same temperature and duration but with $\mathrm{CO}_{2^{-}}$or $\mathrm{O}_{2}$-enriched atmospheres consistently improved the initial inhibition of green and blue molds on all citrus cultivars. Comparably, 15 $\mathrm{kPa} \mathrm{CO} \mathrm{CO}_{2}$ exposures were more effective against green and blue molds than those of 30,50 , or $95 \mathrm{kPa} \mathrm{CO}_{2}$. The use of high $\mathrm{CO}_{2}$ concentrations during cold storage of fresh fruits and vegetables to control postharvest pathogens is based on both their direct toxicity to fungi and their indirect effect on delaying fruit ripening and senescence, therefore reducing fruit susceptibility to decay (17). The direct toxicity of high $\mathrm{CO}_{2}$ levels has been assessed in in vitro studies, where $\mathrm{CO}_{2}$ at $13 \mathrm{kPa}$ prevented spores of $P$. expansum from germinating after exposure for 21 days (10). Short treatments tested in the present study may not exert much delay on fruit senescence; however, they may trigger the production of high levels of antifungal volatile compounds, which increase fruit resistance to rot (43). On the other hand, according to Kader (17), atmospheres with excessively elevated concentrations of $\mathrm{CO}_{2}$ may harm some commodities and induce physiological breakdown and render it more susceptible to pathogens. $\mathrm{CO}_{2}$ concentrations higher than $15 \mathrm{kPa}$ that would result in higher direct toxicity to $P$. digitatum and $P$. italicum were apparently injurious to fruit and resulted in poorer disease control. Accordingly, we observed in previous studies that treatments with $15 \mathrm{kPa} \mathrm{CO}_{2}$ at $33^{\circ} \mathrm{C}$ for $48 \mathrm{~h}$ were significantly better than those with higher $\mathrm{CO}_{2}$ concentrations to maintain the quality of citrus fruits during long cold storage (36). Treatments with a $\mathrm{CO}_{2}$ concentration as high as $95 \mathrm{kPa}$ increased the subsequent production of acetaldehyde and ethyl acetate during cold storage of Ortanique and Nadorcott mandarins, which may be very toxic to pathogenic fungi but caused an important loss of fruit quality including elevated water loss during storage, decrease in acidity, and increase in maturity index (36). These alterations led to an increased susceptibility of fruit to fungal infection and colonization. Inoculated Nadorcott mandarins exposed to hypoxia by increasing the concentration of $\mathrm{N}_{2}$ in the chamber to $95 \mathrm{kPa}$ showed slightly less disease development than airexposed fruit, but this treatment was less effective than those with elevated $\mathrm{CO}_{2}$. The toxicity of low $\mathrm{O}_{2}$ on fungi was assessed in early studies, in which it was observed that the germination of five pathogenic fungi decreased linearly with $\mathrm{O}_{2}$ concentrations decreasing below $4 \%$ (42). Later, in vivo studies showed that storage at $5^{\circ} \mathrm{C}$ for up to 4 weeks 
in atmospheres with $1 \mathrm{kPa} \mathrm{O}_{2}$ reduced decay incidence on Clemenules clementine mandarins, but increased decay incidence on Nadorcott mandarins (23). Hypoxia, either alone or with high concentrations of $\mathrm{CO}_{2}$ has typically a direct fungistatic effect $(10,42)$ that nevertheless is not constantly nor proportionally related to lower fruit decay (23). The effect of these treatments on citrus fruit quality, which varies from neutral to negative $(23,36)$, may influence the host-pathogen interaction and impair the natural resistance of fruit to disease, therefore facilitating the infection by spores that might have escaped the direct toxicity of the treatments. In another set of experiments in our work, treatments at $33^{\circ} \mathrm{C}$ for $48 \mathrm{~h}$ with high levels of $\mathrm{O}_{2}$ controlled green and blue molds to a greater extent and more persistently than those with high levels of $\mathrm{CO}_{2}$

High $\mathrm{O}_{2}$ probably reduces decay by its toxic effect on microbial cells that lack mechanisms to protect themselves from damage (45). Amanatidou et al. (1) found that atmospheres with high concentrations of $\mathrm{O}_{2}$ imposed oxidative stress that led to an increase of intracellularly generated reactive oxygen species (ROS, mainly $\mathrm{O}_{2}{ }_{2}^{-}, \mathrm{H}_{2} \mathrm{O}_{2}$, and free hydroxyl radicals), which disturbed the cellular homeostasis due to catabolic imbalance and resulted in the inhibition of the growth of certain microorganisms. To our knowledge, there are no studies assessing the direct toxicity of high $\mathrm{O}_{2}$ or $\mathrm{CO}_{2}$ atmospheres on $P$. digitatum or $P$. italicum. In early work, bacteria and fungi exposed to 10 atm $\mathrm{O}_{2}$ $(1,013.25 \mathrm{kPa})$ for $8 \mathrm{~h}(8)$, or 7 and 14 days (35) completely halted their growth. On return to air, the fungi treated for $8 \mathrm{~h}$ began to grow after a variable delay period, whereas those treated for 7 or 14 days recovered after longer delay periods or never recovered. Although $P$. digitatum and $P$. italicum were not tested, several Penicillium spp. were among those fungi killed by hyperbaric $\mathrm{O}_{2}$ (35). Other pathogenic imperfecti fungi such as $B$. cinerea or Aspergillus flavus were inhibited by high levels of $\mathrm{O}_{2}(70,80$ and $95 \mathrm{kPa} \mathrm{O}$ ) (16) and it is therefore reasonable to hypothesize that $P$. digitatum and $P$. italicum might be similarly affected. However, it has been reported that direct toxicity of high $\mathrm{O}_{2}$ treatments on microorganisms is generally lower than that of high $\mathrm{CO}_{2}$ treatments $(1,15,44)$. Therefore, an indirect effect by increasing fruit resistance to pathogens may have contributed, as in other pathosystems $(44,46)$, to the higher control of green and blue molds observed in fruit after exposure to high $\mathrm{O}_{2}$. On citrus fruit, Kader and Ben-Yehoshua (19) observed that 80 
$\mathrm{kPa} \mathrm{O}_{2}$ effectively reduced penicillium decay on grapefruit. We also observed (36) that exposure to 30 or $45 \mathrm{kPa} \mathrm{O}_{2}$ at $33^{\circ} \mathrm{C}$ for 24 or $48 \mathrm{~h}$ positively affected citrus quality. Clemenules and Ortanique mandarins exposed to $\mathrm{O}_{2}$ for $48 \mathrm{~h}$ lost less weight after 4 weeks storage at $5^{\circ} \mathrm{C}$ followed by 1 week of shelf life at $20^{\circ} \mathrm{C}$ than air-exposed fruit. Clemenules mandarins exposed to $\mathrm{O}_{2}$ were firmer and had a reduced ethanol content in the juice compared to control fruit. Similarly, Valencia oranges exposed to $30 \mathrm{kPa} \mathrm{O}$ for $48 \mathrm{~h}$ at 20 or $33^{\circ} \mathrm{C}$ lost less weight than air-exposed fruit, while the rest of external and internal fruit quality parameters were not affected (36). One of the positive effects of high $\mathrm{O}_{2}$ treatments on citrus fruit quality might be an increase in their natural resistance to pathogens.

Neither air at curing temperature, gaseous treatments at $20^{\circ} \mathrm{C}$, nor treatments for $8 \mathrm{~h}$ were effective to control green and blue molds on citrus fruits. However, when high $\mathrm{CO}_{2}$ or $\mathrm{O}_{2}$ were applied at $33^{\circ} \mathrm{C}$, decay was inhibited to a greater extent than that expected by the mere addition of the two conditions. There was thus a synergistic effect between high levels of $\mathrm{CO}_{2}$ or $\mathrm{O}_{2}$ and curing temperatures, which was noticeable at all treatments lengths, but was only effective against green and blue molds when treatments were applied for not less than $24 \mathrm{~h}$.

Regarding the induced resistance assays, all citrus cultivars treated before wounding and fungal inoculation showed similar green mold incidence and severity than control fruit. Neither heat nor high $\mathrm{CO}_{2}$ or $\mathrm{O}_{2}$ exposure at the levels used in this study induced any noticeable defensive response in the fruit against green mold, which could be explained by the lack of any injury or pathogen that triggered the defense system of the fruit $(21,27)$, or also by insufficient temperature or treatment length, which were unable to induce any response in the nonwounded fruit. We have recently observed that superficial wounds in the rind of citrus fruits are not always necessary to induce phytoalexin accumulation as a response to a stressing postharvest treatment. Nonwounded Clemenules mandarins X-ray irradiated at 510 or $875 \mathrm{~Gy}$ and stored at $20^{\circ} \mathrm{C}$ for 7 or 14 days synthesized significant amounts of scoparone and scopoletin in the flavedo (C. Rojas-Argudo, unpublished). Nonetheless, the synthesis was substantially higher on mandarins that had been wounded prior to irradiation and inoculated with $P$. digitatum afterwards. 
According to the findings in the present study, exposure of citrus fruits to $15 \mathrm{kPa} \mathrm{CO}$ for $24 \mathrm{~h}$ or to $30 \mathrm{kPa} \mathrm{O}_{2}$ for $48 \mathrm{~h}$ at $33^{\circ} \mathrm{C}$ can be a convenient measure to inhibit green and blue molds after harvest. Treatments were not persistent but a marked inhibition was observed on fruit incubated for up to 7 days at $20^{\circ} \mathrm{C}$, which is a reasonable shelf-life period for domestic or, in the case of Spain, European export markets, especially taking into account that a nontoxic antifungal treatment was applied that could open opportunities for marketing of the fruit. New gaseous combinations should be tested on citrus to increase the effectiveness of the method. For instance, Amanatidou et al. (1) used atmospheres composed by high $\mathrm{O}_{2}$ and high $\mathrm{CO}_{2}$ and found that they were consistently more effective together than when used separately. Thus, superatmospheric $\mathrm{O}_{2}$ concentrations appear to reduce the potential negative effects of high $\mathrm{CO}_{2}$ and allow sensitive commodities to tolerate fungistatic $\mathrm{CO}_{2}$ levels with minimal injury $(19,20)$. The effect of such gaseous treatments on citrus fruits remains to be tested.

Exposure to $\mathrm{CO}_{2}$ or $\mathrm{O}_{2}$ at a relatively low curing temperature of $33^{\circ} \mathrm{C}$ for shorter time periods may be a suitable alternative to the existing effective curing times of 65 to $72 \mathrm{~h}$ and thus facilitate the commercial implementation of curing treatments on citrus. Although the commercial feasibility of heated gas treatments in the conventional citrus industry is questionable due to the treatment costs and the effectiveness, persistence, and availability of existing fungicides, these alternative treatments may be a useful tool to be considered. In an integrated approach, the effectiveness and persistence of these treatments might be enhanced by combining them with other nonpolluting treatments, like for instance sodium carbonate dips, which are known for improving the performance of curing (31). Exposure to high $\mathrm{CO}_{2}$ or $\mathrm{O}_{2}$ leaves no chemical residues on fruit, which enables treated citrus fruit to be potentially traded as organic, considerably increasing the value of the commodity. Higher prices of the final product achieved by compliance with organic fruit production or specific 'green' markets may counteract the cost of establishing and using such postharvest treatments, especially when appropriate facilities are already available for citrus degreening or insecticidal quarantine treatments. 


\section{Acknowledgments}

Fontestad S.A. (Montcada, València) is gratefully acknowledged for providing fruit. This work was partially funded by the Spanish 'Ministerio de Ciencia e Innovación' (MICINN; project AGL200405271) and the European Union (FEDER Program). Clara MontesinosHerrero's doctorate program is supported by the IVIA.

\section{Literature cited}

1 Amanatidou, A., Smid, E. J., and Gorris, L. G. M. 1999. Effect of elevated oxygen and carbon dioxide on the surface growth of vegetable-associated micro-organisms. J. Appl. Microbiol. 86:429438.

2 Barkai-Golan, R. 2001. Postharvest Diseases of Fruit and Vegetables. Elsevier Science B. V., Amsterdam, The Netherlands.

3 Barkai-Golan, R., and Phillips, D. J. 1991. Postharvest heat treatments of fresh fruit and vegetables for decay control. Plant Dis. 75:1085-1089.

4 Ben-Yehoshua, S., Barak, E., and Shapiro, B. 1987. Postharvest curing at high temperatures reduces decay of individually sealed lemons, pomelos, and other citrus fruit. J. Am. Soc. Hort. Sci. 112:658-663.

5 Ben-Yehoshua, S., Beaudry, R. M., Fishman, S., Jayanty, S., and Mir, N. 2005. Modified atmosphere packaging and controlled atmosphere storage. Chapter 4 in: Environmentally Friendly Technologies for Agricultural Produce Quality. S. Ben-Yehoshua, ed. Taylor and Francis Group LLC. Boca Raton, FL.

6 Ben-Yehoshua, S., Kim, J. J., and Shapiro, B. 1989. Curing of citrus fruit. Applications and mode of action. Pages 179-196 in: Fifth Proc. Controlled Atmosphere Research Conf., Vol. 2. June 14-16, Wenatchee, WA.

7 Brown, G. E. 1973. Development of green mold in degreened oranges. Phytopathology 63:1104-1107.

8 Caldwell, J. 1965. Effects of high partial pressures of oxygen on fungi and bacteria. Nature 206:321-323.

9 Chen, X. H., Zheng, Y. H., Yang, Z. F., Cao, S. F., Li, N., and Ma, S. J. 2006. Inhibition of postharvest decay in relation to induced 
disease resistance of strawberry fruit treated with high oxygen. Trans. Chin. Soc. Ag. Eng. 22:208-211.

10 Cossentine, J. E., Sholberg, P., Jensen, L. B. J., Bedford, K., and Shephard, T. 2004. Fumigation of empty fruit bins with carbon dioxide to control diapausing codling moth larvae and Penicillium expansum Link. ex Thom spores. HortScience 39:429-432.

11 Day, B. P. F. 1996. High oxygen modified atmosphere packaging for fresh prepared produce. Postharv. News Info. 7:31N-34N.

12 Eckert, J. W., and Brown, G. E. 1986. Evaluation of postharvest fungicide treatments for citrus fruits. Pages 92-97 in: Methods for Evaluating Pesticides for Control of Plant Pathogens. K. D. Hickey, ed. APS Press, St. Paul, MN.

13 Eckert, J. W., and Eaks, I. L. 1989. Postharvest disorders and diseases of citrus. Pages 179-260 in: The Citrus Industry, Vol. 5. W. Reuter, E. C. Calavan and G. E. Carman, eds. University of California Press, Berkeley, CA.

14 El-Goorani, M. A., and Sommer, N. F. 1981. Effects of modified atmospheres in fruit and vegetable storage. Hort. Rev. 3:412-461.

15 Geysen, S., Geeraerd, A. H., Verlinden, B. E., Michiels, C. W., Van Impe, J. F., and Nicolaï, B. M. 2005. Predictive modeling and validation of Pseudomonas fluorescens growth at superatmospheric oxygen and carbon dioxide concentrations. Food Microbiol. 22:149158.

16 Jacxsens, L., Devlieghere, F., Van der Steen, C., and Debevere, J. 2001. Effect of high oxygen modified atmosphere packaging on microbial growth and sensorial qualities of fresh-cut produce. Int. J. Food Microbiol. 71:197-210.

17 Kader, A. A. 1986. Biochemical and physiological basis for effects of controlled and modified atmospheres on fruits and vegetables. Food Technol. 40:99-104.

18 Kader, A. A., and Arpaia, M. L. 2002. Postharvest handling systems: subtropical fruits. Pages 375-383 in: Postharvest Technology of Horticultural Crops. A. A. Kader, ed. University of California Agriculture and Natural Resources, Pub. 3311. Oakland, CA.

19 Kader, A. A., and Ben-Yehoshua, S. 2000. Effects of superatmospheric oxygen levels on postharvest physiology and 
quality of fresh fruits and vegetables. Postharvest Biol. Technol. 20:1-13.

20 Kader, A. A., and Watkins, C. B. 2000. Modified atmosphere packaging - Toward 2000 and beyond. HortTechnology 10:483-486.

21 Kim, J. J., Ben-Yehoshua, S., Shapiro, B., Henis, Y., and Carmeli, S. 1991. Accumulation of scoparone in heat-treated lemon fruit inoculated with Penicillium digitatum Sacc. Plant Physiol. 97:880885.

22 Lanza, G., and Di Martino Aleppo, E. 1996. Control of green mould of oranges and lemons by curing at high temperatures. Proc. Int. Soc. Citriculture 2:1187-1191.

23 Luengwilai, K., Sukjamsai, K., and Kader, A. A. 2007. Responses of 'Clemenules Clementine' and 'W. Murcott' mandarins to low oxygen atmospheres. Postharvest Biol. Technol. 44:48-54.

24 Montesinos-Herrero, C., del Río, M. A., Rojas-Argudo, C., and Palou, L. 2010. Short-term $\mathrm{O}_{2}$ exposure at curing temperatures to control postharvest penicillium molds on 'Ortanique' hybrid mandarins. Acta Hort. 876:365-371.

25 Montesinos-Herrero, C., and Palou, L. 2010. Combination of physical and low-toxicity chemical postharvest treatments for integrated disease management of citrus fruit: a review. Stewart Postharv. Rev. 1:1:1-11.

26 Mulas, M., and Schirra, M. 2007. The effect of heat conditioning treatments on the postharvest quality of horticultural crops. Stewart Postharv. Rev. 1:3:1-6.

27 Nafussi, B., Ben-Yehoshua, S., Rodov, V., Peretz, J., Ozer, B. K., and D'hallewin, G. 2001. Mode of action of hot-water dip in reducing decay of lemon fruit. J. Agric. Food Chem. 49:107-113.

28 Palou, L. 2009. Control of citrus postharvest diseases by physical means. Tree Forestry Sci. Biotechnol. 3:127-142.

29 Palou, L., Montesinos-Herrero, C., and del Río, M. A. 2006. Shortterm $\mathrm{CO}_{2}$ exposure at curing temperature to control postharvest green mold of mandarins. Acta Hort. 768:257-263.

30 Plaza, P., Usall, J., Torres, R., Lamarca, N., Asensio, A., and Viñas, I. 2003. Control of green and blue mould by curing on oranges during ambient and cold storage. Postharvest Biol. Technol. 28:195198. 
31 Plaza, P., Usall, J., Torres, R., Abadias, M., Smilanick, J. L., Viñas, I. 2004. The use of sodium carbonate to improve curing treatments against green and blue moulds on citrus fruits. Pest Manag. Sci. 60:815-821.

32 Porat, R., Pavoncello, D., Peretz, J., Ben-Yehoshua, S., and Lurie, S. 2000. Effects of various heat treatments on the induction of cold tolerance and on the postharvest qualities of 'Star Ruby' grapefruit. Postharvest Biol. Technol. 18:159-165.

33 Prusky, D., Kobiler, I., Fishman, Y., and Ardi, R. 1993. Induction of resistance of avocado fruit to Colletotrichum gloeosporioides attack by $\mathrm{CO}_{2}$ treatment. Acta Hort. 343:325-330.

34 Richter, D. L. 1987. Synergism: a patent point of view. Pestic. Sci. 19:309-315.

35 Robb, S. M. 1966. Reactions of fungi to exposure to 10 atmospheres pressure of oxygen. J. Gen. Microbiol. 45:17-29.

36 Rojas-Argudo, C., del Río, M. A., Montesinos-Herrero, C., and Palou, L. 2010. Effects of $\mathrm{CO}_{2}$ and $\mathrm{O}_{2}$ shocks at high temperature on postharvest quality of cold-stored citrus fruit. Int. J. Food Sci. Technol. 45:2062-2070.

37 Sánchez-Ballesta, M. T., Jiménez, J. B., Romero, I., Orea, J. M., Maldonado, R., González Ureña, A., Escribano, M. I., and Merodio, C. 2006. Effect of high $\mathrm{CO}_{2}$ pretreatment on quality, fungal decay and molecular regulation of stilbene phytoalexin biosynthesis in stored table grapes. Postharvest Biol. Technol. 42:209-216.

38 Schirra, M., D'hallewin, G., Ben-Yehoshua, S., and Fallik, E. 2000. Host-pathogen interactions modulated by heat treatment. Postharvest Biol. Technol. 21:71-85.

39 Tian, S. P., Fan, Q., Xu, Y., Wang, Y., and Jiang, A. L. 2001. Evaluation of the use of high $\mathrm{CO}_{2}$ concentrations and cold storage to control Monilinia fructicola on sweet cherries. Postharvest Biol. Technol. 22:53-60.

40 Tian, S. P., Jiang, A. L., Xu, Y., and Wang, Y. 2004. Responses of physiology and quality of sweet cherry fruit to different atmospheres in storage. Food Chem. 87:43-49.

41 Tian, S. P., Xu, Y., Jiang, A. L., and Gong, Q. 2002. Physiological and quality responses of longan fruit to high $\mathrm{O}_{2}$ or high $\mathrm{CO}_{2}$ atmospheres in storage. Postharvest Biol. Technol. 24:335-340. 
42 Wells, J., and Uota, M. 1970. Germination and growth of five fungi in low-oxygen and high-carbon dioxide atmospheres. Phytopathology 60:50-53.

43 Wilson, C. L., Franklin, J. D., and Otto, B. E. 1987. Fruit volatiles inhibitory to Monilinia fructicola and Botrytis cinerea. Plant Dis. 71:316-319.

44 Wszelaki, A. L., and Mitcham, E. J. 2000. Effects of superatmospheric oxygen on strawberry fruit quality and decay. Postharvest Biol. Technol. 20:125-133.

45 Yahia, E. M., and Sholberg, P. L. 2009. Effects on fungal diseases. Pages 193-212 in: Modified and Controlled Atmospheres for the Storage, Transportation, and Packaging of Horticultural Commodities. Recent Advances. E. M. Yahia, ed. CRC Press, Boca Raton, FL.

46 Yang, Z. F., Zheng, Y. H., Cao, S. F., Li, N., Ma, S. J., Chen, X. H., and Wang, X.X. 2005. Inhibition of postharvest decay and induction of defensive enzymes by pure oxygen in Chinese bayberry fruit. J. Plant Phys. Mol. Biol. 31:425-430.

47 Zhang, J., and Swingle, P. P. 2005. Effects of curing on green mold and stem -end rot of citrus fruit and its potential application under Florida packing system. Plant Dis. 89:834-840.

48 Zheng, Y., Fung, R., Wang, S., and Wang, C. Y. 2008. Transcript levels of antioxidative genes and oxygen radical scavenging enzyme activities in chilled zucchini squash in response to superatmospheric oxygen. Postharvest Biol. Technol. 47:151-158.

49 Zheng, Y., and Wang, C. Y. 2007. Effect of high oxygen atmospheres on quality of fruits and vegetables. Stewart Postharv. Rev. 2:1:1-8. 
Chapter 5

Synergism between potassium sorbate dips and brief exposure to high $\mathrm{CO}_{2}$ or $\mathrm{O}_{2}$ at curing temperature for control of citrus postharvest green and blue molds

\author{
CLARA MONTESINOS-HERRERO and LLUÍS PALOU
}

Laboratori de Patologia, Centre de Tecnologia Postcollita (CTP), Institut Valencià d'Investigacions Agràries (IVIA) Apartat Oficial, 46113 Montcada, València, Spain

Reference: Crop Protection 2016, 81, 43-46. 



\begin{abstract}
Synergistic effects and very effective control of citrus postharvest green and blue molds, caused by Penicillium digitatum and Penicillium italicum, respectively, were observed on artificially inoculated 'Valencia' oranges and 'Clemenules' and 'Ortanique' mandarins after a potassium sorbate (PS) treatment was followed by 2 days of storage in atmospheres of elevated $\mathrm{CO}_{2}$ or $\mathrm{O}_{2}$ at a curing temperature. A combined treatment consisting of 60 -s dips in aqueous solutions of $3 \%$ PS heated to $62{ }^{\circ} \mathrm{C}$ was followed by 48 -h exposure to air, $15 \mathrm{kPa} \mathrm{CO} 2$ or $30 \mathrm{kPa} \mathrm{O}_{2}$ at $33^{\circ} \mathrm{C}$. Control treatment was a 60-s water dip at $20{ }^{\circ} \mathrm{C}$ followed by $24-\mathrm{h}$ exposure to air at $20^{\circ} \mathrm{C}$. Synergism was observed on citrus fruit either incubated at $20{ }^{\circ} \mathrm{C}$ for up to 22 days, simulating direct commercialization, or stored at $5{ }^{\circ} \mathrm{C}$ for up to 45 days, simulating commercial cold storage. This research offers potential new tools to the citrus industry for implementation of nonpolluting integrated postharvest disease management programs, especially devoted to high added value organic markets or export markets with zero residue tolerance.
\end{abstract}

Keywords: Postharvest decay; Penicillium digitatum; P. italicum; food preservatives; potassium sorbate; antifungal controlled atmospheres; integrated disease control.

\title{
Introduction
}

Green mold, caused by Penicillium digitatum (Pers.:Fr.) Sacc., and blue mold, caused by Penicillium italicum Wehmer, are the cause of the most important economic losses due to postharvest decay in the citrus industry in Spain and other countries with Mediterranean-type climate (Palou, 2014). For many years, these diseases have been controlled by the application of conventional fungicides such as imazalil (IMZ), sodium orthophenylphenate (SOPP) or thiabendazole (TBZ), but now there are important general restrictions to the use of these products. Concerns about the effect of chemical residues on human health and the environment have led major European and worldwide markets to demand fruit that comply with zero or very low chemical residue tolerances. Moreover, the continuous and in some cases uncontrolled use of these 
fungicides in the past has caused the rise of resistant strains of the pathogens in many citrus packinghouses. Since effective decay control is imperative for the citrus industry, new low toxicity control methods are needed to replace or reduce the present use of synthetic fungicides (Palou et al., 2008).

Food additives or GRAS (generally regarded as safe) substances such as carbonates, sorbates, parabens, benzoates, etc. (Palou et al., 2001, 2002; Smilanick et al., 2008; Moscoso-Ramírez et al., 2013) and some brief exposures to high $\mathrm{O}_{2}$ or $\mathrm{CO}_{2}$ tested in our laboratory in recent years showed a good potential as alternative means for the control of citrus postharvest decay. Particularly, 60-s dips in aqueous solutions of 3\% potassium sorbate (PS) heated to $62{ }^{\circ} \mathrm{C}$ (Montesinos-Herrero et al., 2009) and 24- or 48-h exposures to $15 \mathrm{kPa} \mathrm{CO}_{2}$ or $30 \mathrm{kPa} \mathrm{O}$ at the curing temperature of $33{ }^{\circ} \mathrm{C}$ (Montesinos-Herrero et al., 2012) effectively controlled green and blue molds in several citrus cultivars and were selected among the most promising nonpolluting alternative treatments. The objective of this work was to evaluate the compatibility and possible synergistic effects between these two types of treatments on oranges and mandarins incubated at $20^{\circ} \mathrm{C}$ or cold-stored at $5{ }^{\circ} \mathrm{C}$.

\section{Materials and methods}

Fruit used in the trials were oranges (Citrus sinensis (L.) Osbeck) cv. 'Valencia', clementine mandarins (Citrus clementina Hort. ex Tanaka) cv. 'Clemenules', and hybrid mandarins cv. 'Ortanique' [Citrus reticulata Blanco x ( $C$. sinensis x $C$. reticulata)]. Fruit were harvested from commercial orchards and no postharvest treatments were applied. Inoculum was prepared from isolated local strains of $P$. digitatum and $P$. italicum included in the IVIA CTP fungal culture collection of postharvest pathogens. The two pathogens were grown on potato dextrose agar (PDA) petri dishes at $25{ }^{\circ} \mathrm{C}$ for 7-14 days. Spore suspensions of $10^{6}$ spores $/ \mathrm{mL}$ were prepared and fruit were inoculated by dipping the tip ( $1 \mathrm{~mm}$ wide, $2 \mathrm{~mm}$ long) of a sterile rod in the spore suspension and inserting it once in the equatorial area of the fruit rind. The two pathogens were inoculated in opposite sides of each fruit.

Stainless steel 10-L buckets were used for 60-s dip treatments with $3 \%$ (w/v) PS. Salt solutions were heated to $62{ }^{\circ} \mathrm{C}$ inside a $250-\mathrm{L}$ water tank provided with two electric resistances $(4.5 \mathrm{~kW}$ each), a thermostat, and 
an automatic water-recirculating system. About $24 \mathrm{~h}$ after inoculation, fruit were placed into $18 \mathrm{~L}$ multi-perforated wall stainless steel containers, exactly fitting in the previously mentioned buckets and completely immersed in the corresponding solution for $60 \mathrm{~s}$. Control fruit were immersed in water at $20^{\circ} \mathrm{C}$ for the same time. After treatment, fruit were rinsed with tap water at low pressure, dried in a packingline air tunnel at $45{ }^{\circ} \mathrm{C}$ for $15 \mathrm{~s}$, and exposed to the different gas treatments. Chambers used for gas exposure consisted of hermetically sealed, transparent polymethyl methacrylate cabinets $(82 \times 62 \times 87 \mathrm{~cm})$ fitted with outlet and inlet ports through which $\mathrm{O}_{2}$ or $\mathrm{CO}_{2}$ (Alphagaz, Air Liquide España S.A., Madrid, Spain) were injected to the desired concentrations. The cabinets were also fitted with internal basal water trays that allowed achieving a high relative humidity $(\mathrm{RH})$ of about $95 \pm 5 \%$. Cabinets were inside a $40 \mathrm{~m}^{3}$ chamber conditioned at the experimental temperature $\left(20\right.$ or $33^{\circ} \mathrm{C}$ for 24 or $48 \mathrm{~h}$ ). Control fruit were exposed to air at $20^{\circ} \mathrm{C}$ for $24 \mathrm{~h}$. Levels of $\mathrm{CO}_{2}, \mathrm{O}_{2}$, temperature and $\mathrm{RH}$ were set and continuously monitored by means of a computer-controlled system (Control-Tec ${ }^{\circledR}$, Tecnidex S.A., Paterna, València, Spain). For each combination of treatments, 3 replicates of 25 fruit each were used. Depending on the trial, treated fruit were incubated at $20^{\circ} \mathrm{C}$ for up to 22 days, or cold-stored at $5{ }^{\circ} \mathrm{C}$ and $90 \% \mathrm{RH}$ for up to 42 days. During these periods, disease incidence (number of infected wounds) and visible skin damage were periodically assessed. Every experiment was conducted twice.

For each cultivar, pathogen, treatment and evaluation date, disease reduction compared to control fruit was calculated by means of the equation: (\% infected wounds in control fruit - \% infected wounds in treated fruit $/ \%$ infected wounds in control fruit) x 100. On 'Valencia' oranges, average green and blue mold incidence in control fruit was 89, 98 and $100 \%$ and 65, 93 and $100 \%$, respectively, after 4, 8, and 14 days of incubation at $20{ }^{\circ} \mathrm{C}$. On 'Clemenules' mandarins, incidence of both green and blue molds in control fruit was $100 \%$ after 8 days of incubation at $20^{\circ} \mathrm{C}$ and also $100 \%$ after 14 days of storage at $5{ }^{\circ} \mathrm{C}$. On 'Ortanique' mandarins, incidence of both green and blue molds in control fruit was $100 \%$ after 8 days of incubation at $20^{\circ} \mathrm{C}$, while it was 96 and $97 \%$ and 100 and $100 \%$, respectively, after 14 and 28 days of storage at $5{ }^{\circ} \mathrm{C}$. Data from repeated experiments were statistically analyzed using analysis of 
variance (ANOVA) applied to percentages previously subjected to the arc-sine transformation in order to assure the homogeneity of variances. When appropriate, Fisher's Protected LSD test $(P<0.05)$ was used for means separation. The term synergy was applied as defined by Richer (1987), where the effectiveness of a combination of treatments exceeds the prediction of the effectiveness of their additive action estimated by Limpel's formula $(\mathrm{Ee}=\mathrm{X}+\mathrm{Y}-(\mathrm{XY} / 100))$.

\section{Results and discussion}

The reduction of disease incidence obtained with different treatments and combinations applied to 'Valencia' oranges and 'Clemenules' and 'Ortanique' mandarins incubated at $20{ }^{\circ} \mathrm{C}$ is shown in Fig. 1. On 'Valencia' oranges treated and incubated at $20{ }^{\circ} \mathrm{C}$ for 8 or 14 days, dip treatments with $3 \% \mathrm{PS}$ at $62^{\circ} \mathrm{C}$ for $60 \mathrm{~s}$ followed by 24-h exposure to either air at 20 or $33{ }^{\circ} \mathrm{C}$ or $15 \mathrm{kPa} \mathrm{CO}$ at $33{ }^{\circ} \mathrm{C}$, resulted in general high efficacy of PS treatments and general low efficacy of 24-h gaseous treatments. Furthermore, synergism between PS treatment and exposures to $33{ }^{\circ} \mathrm{C}$ was observed, although exposure to $15 \mathrm{kPa} \mathrm{CO}_{2}$ did not significantly improve the efficacy of treatments with air at that temperature. These combined treatments were further assayed with mandarins, but using gas treatments of $30 \mathrm{kPa} \mathrm{O}_{2}$ and testing also longer exposures of $48 \mathrm{~h}$. In general, efficacy was higher on 'Ortanique' than on 'Clemenules' mandarins, and higher against green mold than blue mold. The poor effectiveness of gaseous exposures as brief as $24 \mathrm{~h}$ and the synergism between PS dip treatments and exposures to $33{ }^{\circ} \mathrm{C}$ were confirmed, especially when high $\mathrm{O}_{2}$ was applied. 


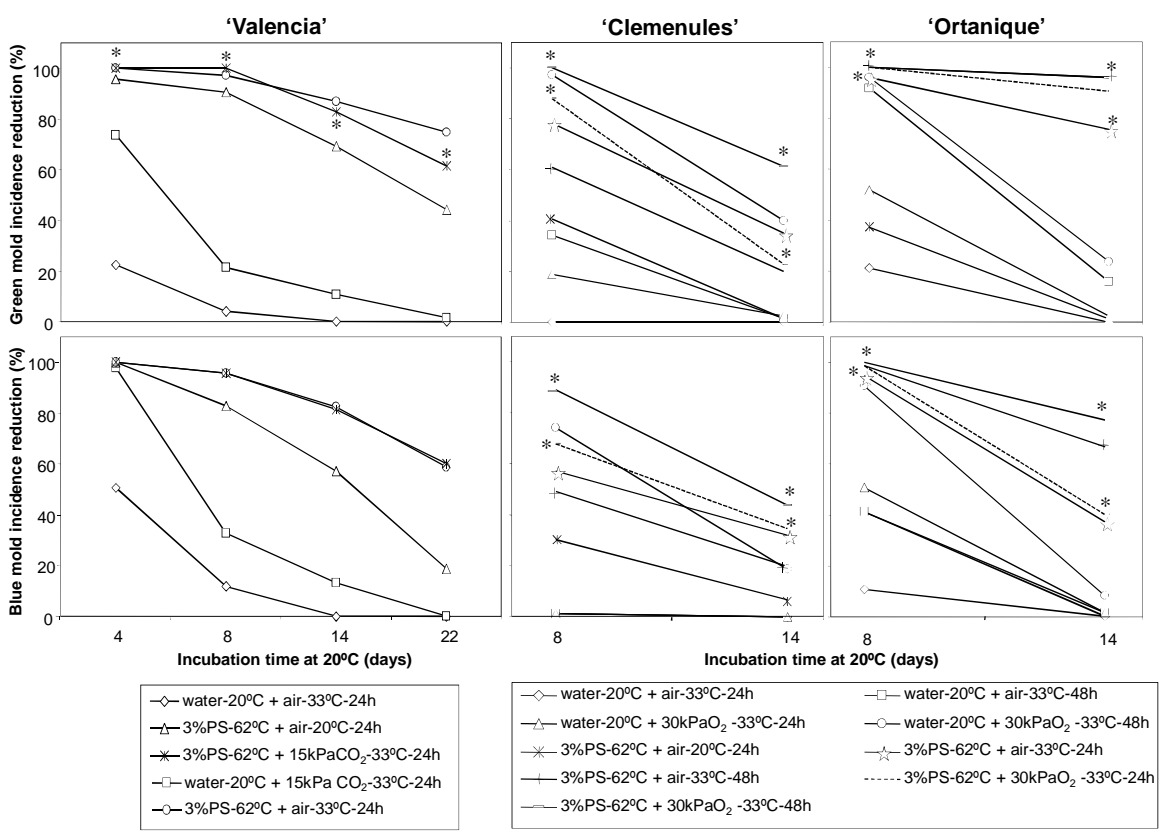

Figure 1. Reduction of the incidence of green and blue molds with respect to control fruit (60-s water dip at $20{ }^{\circ} \mathrm{C}+$ exposure to air at $20^{\circ} \mathrm{C}$ for $24 \mathrm{~h}$ ) on 'Valencia' oranges and 'Clemenules' and 'Ortanique' mandarins artificially inoculated with Penicillium digitatum or $P$. italicum, respectively, treated $24 \mathrm{~h}$ later with the indicated combinations of potassium sorbate (PS) dips and gaseous treatments, and incubated at $20{ }^{\circ} \mathrm{C}$ for up to 22 days. For each cultivar and incubation time, treatment means are significantly (no symbol) or not significantly (ns) different according to Fisher's protected LSD $(P<0.05)$ test applied after an ANOVA. (*) Synergistic effect between PS and gaseous treatments according to Limpel's formula.. 


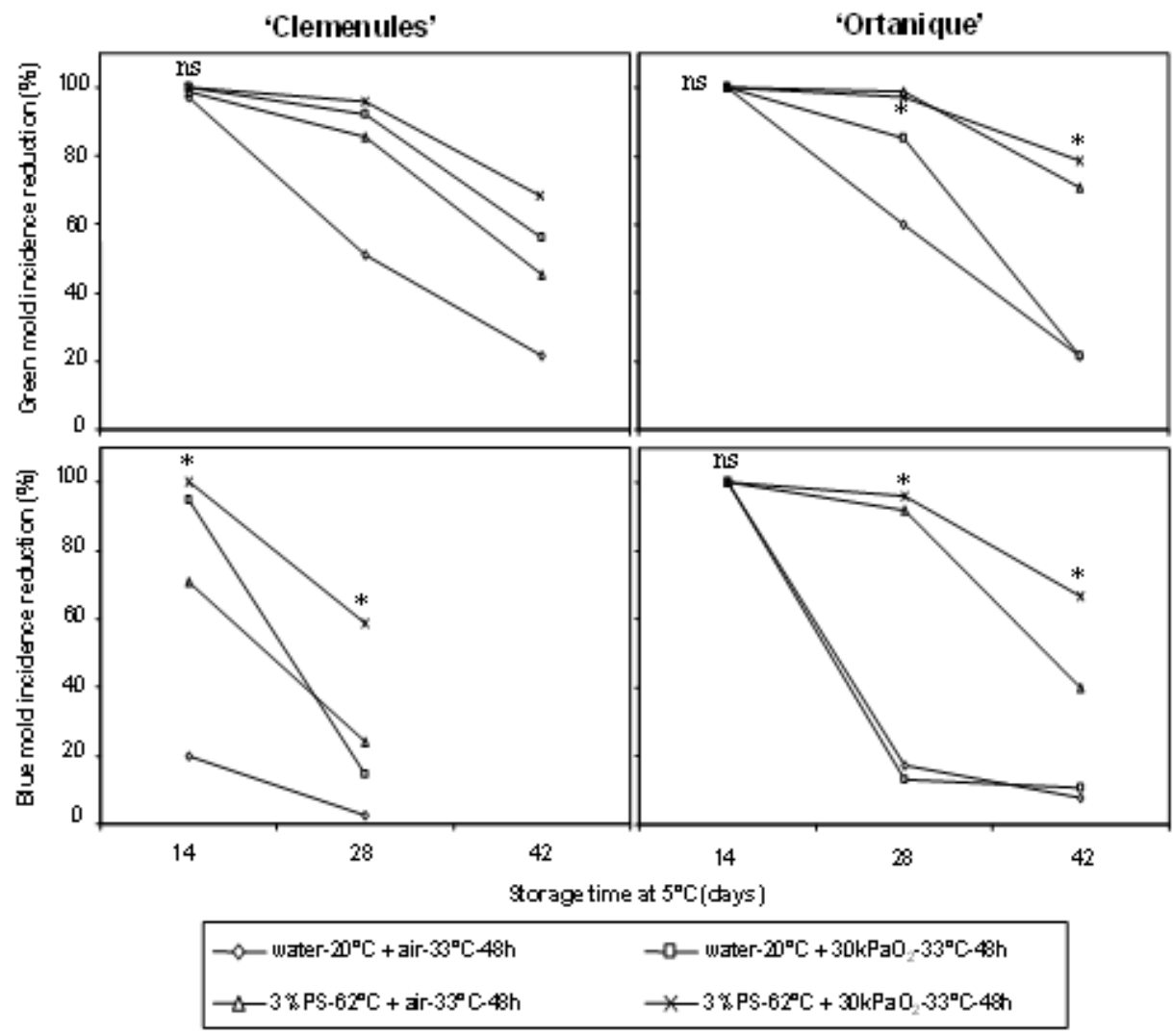

Figure 2. Reduction of the incidence of green and blue molds with respect to control fruit $\left(60\right.$-s water dip at $20{ }^{\circ} \mathrm{C}+$ exposure to air at $20{ }^{\circ} \mathrm{C}$ for $24 \mathrm{~h}$ ) on 'Clemenules' and 'Ortanique' mandarins artificially inoculated with Penicillium digitatum or P. italicum, respectively, treated $24 \mathrm{~h}$ later with the indicated combinations of potassium sorbate (PS) dips and gaseous treatments, and stored at $5{ }^{\circ} \mathrm{C}$ for up to 42 days. For each cultivar and cold storage time, treatment means are significantly (no symbol) or not significantly (ns) different according to Fisher's Protected LSD $(P<0.05)$ test applied after an ANOVA. (*) Synergistic effect between PS and gaseous treatments according to Limpel's formula. 
In mandarins stored at $5^{\circ} \mathrm{C}$ (Fig. 2), treatment efficacy was also higher on 'Ortanique' than 'Clemenules' mandarins and against green mold than blue mold. Synergism between treatments was also marked. Green mold reduction on 'Ortanique' mandarins treated with PS and $30 \mathrm{kPa} \mathrm{O}_{2}$ for 48 $\mathrm{h}$ after 14, 28, and 42 days of cold storage was 100, 97, and 79\%, respectively. In all cases, a fungistatic rather than fungicidal effect of the treatments was observed, since their disease control ability decreased as incubation or cold storage periods increased, and it was dependent on the cultivar. Irrespective of the combination of treatments and cultivar, no external damage was observed on the rind of treated fruit.

In the present study, the high efficacy of PS aqueous dips (Smilanick et al., 2008; Montesinos-Herrero et al., 2009) and brief exposures to high $\mathrm{CO}_{2}$ or $\mathrm{O}_{2}$ at curing temperature (Montesinos-Herrero et al., 2012) was confirmed and an important synergistic effect between these treatments was observed. Therefore, the combination of these treatments could be an alternative for the reduction of the long curing times (65 to $72 \mathrm{~h}$ ) that are currently required for effective control of citrus green and blue molds (Plaza et al., 2003), thus facilitating the commercial implementation of curing treatments. Future research should focus on the evaluation of these treatments in commercial scale trials with naturally infected citrus fruit and on the assessment in these trials of the effect of the combined treatments on the quality of long-term cold stored fruit.

This research offers potential new tools to the citrus industry for implementation of nonpolluting integrated postharvest disease management programs, especially devoted to high added value organic markets or export markets with zero residue tolerance. In spite of the highly satisfactory results obtained in these tests, the general commercial implementation of this combination of alternative treatments in citrus packinghouses working with fruit for conventional markets is currently hindered by the present availability of convenient conventional fungicides and the high implementation and maintenance costs of gaseous treatments

\section{Acknowledgments}

The authors thank Fontestad S.A. (Montcada, València) for providing fruit and technical assistance. This study was partially funded by the 
Spanish 'Ministerio de Educación y Ciencia' (project AGL2004-05271) and the EU (FEDER Program).

\section{Literature cited}

Montesinos-Herrero, C., del Río, M.A., Pastor, C., Brunetti, O., Palou, L., 2009. Evaluation of brief potassium sorbate dips to control postharvest penicillium decay on major citrus species and cultivars. Postharvest Biology and Technology 52, 117-125.

Montesinos-Herrero, C., del Río, M.A., Rojas-Argudo, C., Palou, L., 2012. Short exposure to high $\mathrm{CO}_{2}$ and $\mathrm{O}_{2}$ at curing temperature to control postharvest diseases of citrus fruit. Plant Disease 96, 423-430.

Moscoso-Ramírez, P.A., Montesinos-Herrero, C., Palou, L., 2013. Characterization of postharvest treatments with sodium methylparaben to control citrus green and blue molds. Postharvest Biology and Technology 77, 128-137.

Palou, L., 2014. Penicillium digitatum, Penicillium italicum (Green mold, Blue mold). In: Bautista-Baños, S. (Ed.), Postharvest Decay. Control Strategies. Academic Press, Elsevier Inc., London, UK, pp. 45-102.

Palou, L., Smilanick, J.L., Droby, S., 2008. Alternatives to conventional fungicides for the control of citrus postharvest green and blue molds. Stewart Postharvest Review 2:2, 1-16.

Palou, L., Smilanick, J.L., Usall, J., Viñas, I., 2001. Control of postharvest blue and green molds of oranges by hot water, sodium carbonate, and sodium bicarbonate. Plant Disease 85, 371-376.

Palou, L., Usall, J., Smilanick, J.L., Aguilar, M.J., Viñas, I., 2002. Evaluation of food additives and low-toxicity compounds as alternative chemicals for the control of Penicillium digitatum and Penicillium italicum on citrus fruit. Pest Management Science 58, 459-466.

Plaza, P., Usall, J., Torres, R., Lamarca, N., Asensio, A., Viñas, I., 2003. Control of green and blue mould by curing of oranges during ambient and cold storage. Postharvest Biology and Technology 28, 195-198.

Richer, D.L., 1987. Synergism - a patent view. Pesticide Science 19, 309315. 
Smilanick, J.L., Mansour, M.F., Mlikota-Gabler, F., Sorenson, D., 2008. Control of citrus postharvest green mold and sour rot by potassium sorbate combined with heat and fungicides. Postharvest Biology and Technology 47, 226-238. 

Chapter 6

\section{Control of citrus postharvest decay by ammonia gas fumigation and its influence on the efficacy of the fungicide imazalil}

CLARA MONTESINOS-HERRERO ${ }^{1}$, JOSEPH L. SMILANICK ${ }^{2}$, J.

STEVEN TEBBETS ${ }^{2}$, SPENCER WALSE $^{2}$ and LLUÍS PALOU ${ }^{1}$

${ }^{1}$ Laboratori de Patologia, Centre de Tecnologia Postcollita (CTP) Institut Valencià d'Investigacions Agràries (IVIA) Apartat Oficial, 46113 Montcada, València, Spain

${ }^{2}$ United States Department of Agriculture - Agricultural Research Service, San Joaquin Valley Agricultural Sciences Center 9611 South Riverbend Avenue, Parlier, California 93648 USA

Reference: Postharvest Biology and Technology, 2011, 59, 85-93. 



\begin{abstract}
Postharvest green mold and blue mold, caused by Penicillium digitatum and $P$. italicum, respectively, were effectively controlled by fumigation of lemons and oranges for $6 \mathrm{~h}$ at $22^{\circ} \mathrm{C}$ with two applied dosages of 3000 $\mu \mathrm{L} \mathrm{L}^{-1}$ of ammonia that was injected initially and again $2 \mathrm{~h}$ later. This treatment did not injure oranges, however, it caused the tissue within previously injured areas on the rind of lemons to become darker in color. Fumigation of lemons with $6000 \mu \mathrm{L} \mathrm{L}^{-1}$ of ammonia slightly accelerated the natural transition of rind color from green to yellow. The germination of conidia of $P$. italicum was more sensitive to ammonia than those of $P$. digitatum, although many survived fumigation. About $30 \%$ of the conidia of $P$. digitatum and $10 \%$ of those of $P$. italicum could germinate after a 6 $\mathrm{h}$ fumigation where two injections of $6000 \mu \mathrm{L} \mathrm{L}^{-1}$ of ammonia were applied, one initially and a second $2 \mathrm{~h}$ later. Ammonia fumigation controlled an isolate of $P$. digitatum with a high level of resistance to imazalil (IMZ). The influence of ammonia fumigation on the effectiveness of this common postharvest fungicide was examined. When fruit were first immersed in 10 or $30 \mathrm{mg} \mathrm{L}^{-1} \mathrm{IMZ}$ (about $10 \%$ of typical commercial rates) before ammonia fumigation, a single fumigation with $1500 \mu \mathrm{L} \mathrm{L}^{-1}$ of ammonia was adequate to control both diseases and the increase in effectiveness was usually additive and sometimes synergistic. This effect was probably due in part to the influence of $\mathrm{pH}$ on IMZ activity, because the neutral form of IMZ increases with increasing $\mathrm{pH}$ and it has markedly higher antifungal activity than the ionized molecule. Fumigation with 1500,3000 , or $6000 \mu \mathrm{L}$ of ammonia per liter increased the $\mathrm{pH}( \pm \mathrm{SD})$ of albedo tissue of pre-existing wounds on oranges and lemons from $5.9( \pm 0.2)$ before fumigation by $0.6( \pm 0.3), 0.9( \pm 0.4)$, or 1.3 ( \pm 0.3$)$ units, respectively. IMZ can be applied immediately after harvest by drenching fruit within harvest bins with aqueous IMZ solutions. Subsequent ammonia fumigation on their arrival to packinghouses may be a feasible practice, since it could employ the existent ethylene degreening chambers present at all packinghouses, if these were modified to be gas tight. Ammonia could replace synthetic fungicides or augment IMZ performance in citrus postharvest decay management. Its capacity to control IMZ resistant isolates of $P$. digitatum, common in citrus packinghouses, is particularly valuable.
\end{abstract}


Keywords:

ammonia

green mold

blue mold

Penicillium digitatum

Penicillium italicum

\section{Introduction}

The most significant decay loses in arid production areas, such as Spain and California, during storage and marketing of citrus fruit are caused by green and blue molds of citrus, caused by Penicillium digitatum (Pers.:Fr) Sacc., and P. italicum Wehmer, respectively. Initially, these diseases were controlled by immersing fruit in heated solutions of borax, sodium bicarbonate, or sodium carbonate, later, synthetic fungicides such as sodium ortho-phenylphenate, imazalil, or thiabendazole (Eckert and Eaks, 1989) were used, and the last two remain in common use. Their repeated use has given rise to resistant biotypes of the pathogens that has diminished their effectiveness (Bus et al., 1991; Holmes and Eckert, 1999; Kinay et al., 2007). More recently the 'reduced-risk' fungicides azoxystrobin, pyrimethanil and fludioxonil were introduced (Adaskaveg and Förster, 2010). To control fungicide resistant isolates, treatment of fruit in heated tanks has again become popular, often containing potassium sorbate (Montesinos-Herrero et al., 2009), sodium carbonate, or sodium bicarbonate (Montesinos-Herrero and Palou, 2010), sometimes alone or in mixtures with conventional fungicides (Palou et al., 2008; Smilanick et al., 2005; Smilanick et al., 2008). Significant issues remain regarding the use of fungicides to manage these diseases, including concerns about the impact of the fungicide residues on human health and the environment (Bates, 2002; Dezman et al., 1986), the lack of residue tolerances in some markets, disposal of the used tank solutions, chemical costs, and the need to produce residue-free fruit that comply with 'chemical free' or 'organic' marketing programs.

Ammonia fumigation was developed and rigorously evaluated more than 50 years ago but was not adopted because of the inconvenience and training needed to implement it (Eckert, 1967) and the fact the first 
generation of the synthetic fungicides, sodium ortho-phenylphenate and diphenyl, had been introduced. Since that time developments within the citrus industry make revisiting ammonia fumigation timely. It could be a tool in the management of fungicide resistant pathogens. It is likely ammonia does not deposit residues of dietary concern and it could conceivably be part of 'residue-free' or 'organic' programs. Large capacity fumigation chambers are present in citrus packinghouses where ethylene gas is applied to eliminate the green rind color for marketing purposes (Wardowski et al., 2006); these could be made gas-tight and adapted for ammonia fumigation. The use of a gas for decay control purposes itself offers significant advantages over fungicides applied on packinglines; fumigation can be applied in mass to fruit in cartons or bins, and the need for mechanical handling and the rind injuries it can cause is avoided.

The objectives of this work were to assess the effectiveness of brief ammonia fumigations to control of citrus green and blue molds and its influence on fruit quality. Several aspects of ammonia fumigation had not been assessed in prior work. To determine the interaction of ammonia fumigation with imazalil, fruit were treated with imazalil before ammonia fumigation to evaluate their interaction. The control of a $P$. digitatum isolate with a high degree of imazalil resistance by ammonia fumigation, the toxicity of ammonia gas to conidia of $P$. digitatum and $P$. italicum, and its effect on the $\mathrm{pH}$ of exposed albedo tissue and the rate of transition of green to yellow color of lemon fruit were determined. Ammonia concentration was measured during fumigation to determine losses of the gas during fumigation by sorption to chamber walls and fruit.

\section{Materials and methods}

\subsection{Fruit}

'Eureka' lemons (Citrus limon (L.) Burm) and 'Valencia' oranges (Citrus sinensis (L.) Osbeck) were used in this study. Lemons were collected from field bins in a packinghouse in Tulare County (California, USA) one day after harvest. The oranges were harvested by hand from a grove of the University of California, Lindcove Research and Extension Center (Exeter, CA). No fungicides had been applied before harvest and 
no postharvest treatments had been applied to any of these fruit. Before use, fruits were stored at $15{ }^{\circ} \mathrm{C}$ for less than two weeks. Fruits were washed and randomized before the experiments. To determine the influence of ammonia fumigation on rind quality, fresh wounds were made at 3 points in the equatorial zone by cutting the flavedo with the tip of a knife leaving an open albedo area of $5 \mathrm{~mm}$ in diameter and $2 \mathrm{~mm}$ in depth immediately before fumigation.

\subsection{Inoculum}

All pathogens were isolated from infected lemon fruit and cultured for one to two weeks on potato dextrose agar (PDA, Difco Laboratories, Detroit) at $25^{\circ} \mathrm{C}$. Isolates used were two $P$. digitatum biotypes (IMZsensitive D90 and IMZ-resistant D201) and an isolate of $P$. italicum. The virulence, growth, and other characteristics of these $P$. digitatum isolates were characterized in prior work (Kinay et al., 2007). Isolate PD90 is representative of the IMZ sensitive isolates $\left(\mathrm{EC}_{50}\right.$ on PDA of $0.05 \mathrm{mg} \mathrm{L}^{-1}$ IMZ) commonly encountered in citrus groves, while isolate D201 is representative of the IMZ resistant isolates $\left(\mathrm{EC}_{50}\right.$ on PDA of $1.75 \mathrm{mg} \mathrm{L}^{-1}$ IMZ) commonly encountered in packinghouses (Holmes and Eckert, 1999; Kinay et al., 2007). Suspensions containing $10^{6}$ conidiamL $^{-1}$ were prepared by measuring the concentration of an initial preparation of conidia with a spectrophotometer and diluting the suspension until the absorbance was 0.1 ( $P$. digitatum) or 0.11 absorbance $(P$. italicum). Fruit were inoculated by briefly dipping a stainless steel rod with a 1-mm wide and 2-mm long tip into the inoculum solution, and then immediately making a puncture on the equator of the fruit. Inoculated fruit were left at room temperature for $24 \mathrm{~h}$ before treatment.

\subsection{Ammonia fumigation}

Fruit were placed in $0.242-\mathrm{m}^{3}$ steel chambers with air circulation fans for fumigation with anhydrous ammonia (Airgas Inc., Radnor, PA, USA) or stored in air at $20^{\circ} \mathrm{C}$ (control). The chambers were housed inside a temperature controlled room $\left(22^{\circ} \mathrm{C}\right.$ ) and attached to an exhaust manifold so the fumigant was safely exhausted from the chamber at the end of the exposure period. There was no detectable loss of fumigant due to leakage. Fruit were pre-conditioned overnight to the desired treatment temperature and weighed before being fumigated. The load factor 
(percentage of the chamber volume occupied by the fruit ${ }^{ \pm}$SD) with 20 $\mathrm{kg}$ of fruit inside the chambers was approximately $20 \pm 1 \%$. Initial concentrations of 1500,3000 and $6000 \mu \mathrm{L} \mathrm{L}^{-1}$ ammonia were injected by extracting a calculated volume of gas from the ammonia cylinder using a syringe (models S-500 or S-1500, Hamilton Co., Reno, NV, USA) and injecting it into the chamber through a stainless steel LuerLok ${ }^{\circledR}$ valve to which the Teflon ${ }^{\circledR}$ LuerLok $^{\circledR}$ tip of the syringe was connected. Ammonia gas concentrations were recorded at the beginning of the fumigation $( \pm 2$ $\mathrm{min}$ ), and after 2, 4, and $6 \mathrm{~h} \mathrm{(} \pm 2 \mathrm{~min})$. Ammonia detector tubes (models 3HM and 3M, Gastec Corporation, Ayase-City, Japan) and gas sampling pump (model GV-100, Sensidyme/Gastec, Clearwater, Florida, USA) were used to make these measurements.

Chambers were loaded with $0,3,10$ or $20 \mathrm{~kg}$ of fruit and injected with ammonia to a calculated applied dosage of $6000 \mu \mathrm{L} \mathrm{L}^{-1}$ ammonia, then repeated measurements were taken as described previously in order to determine the influence of the amount of fruit within chamber on the ammonia concentration. The concentration of ammonia during fumigation in the chamber was also measured and a concentration-time product (C-T) was calculated by the method of Bond (1984), which is the area under the line depicting the concentration of ammonia during fumigation expressed in $\mu \mathrm{L} \mathrm{L}^{-1} \mathrm{~h}^{-1}$. After fumigation, fruit were incubated at $20^{\circ} \mathrm{C}$ and the number of infected fruit and the sporulation from decay lesions were observed after 4 and 7 days, and again after 10 days when oranges were evaluated. In a second set of experiments, the same procedure was employed except a second injection into the chamber of the calculated initial applied dosage of ammonia was done $2 \mathrm{~h}$ after the first injection. These double injections of 1500,3000 , or $6000 \mu \mathrm{L} \mathrm{L}^{-1}$ ammonia were depicted as $2 \times 1500,2 \times 3000$, or $2 \times 6000 \mu \mathrm{L} \mathrm{L}^{-1}$, respectively.

\subsection{Influence of ammonia fumigations on germination of conidia}

Conidia of $P$. digitatum isolate D201, $P$. digitatum isolate D90, and $P$. italicum were deposited on microscope slide cover slips and placed in the fumigation chambers where they were exposed to ammonia gas at initial concentrations of 1500,3000 , or $6000 \mu \mathrm{L} \mathrm{L}^{-1}$. Control samples were similarly prepared but not fumigated. After fumigation, the cover slips were placed in sterile centrifuge tubes and the conidia were suspended by 
adding sterile water with $0.05 \%$ (w/v) Triton X-100 to the tubes. A volume of $20 \mu \mathrm{L}$ of each conidial suspension was placed on the surface of PDA. After $12 \mathrm{~h}$ incubation at $25^{\circ} \mathrm{C}$, the number of germinated and non-germinated conidia in each Petri dish were counted by observation of 150 to 250 conidia from each isolate using a compound microscope $(200 \times)$.

\subsection{Interactions between imazalil treatment and subsequent ammonia fumigation}

In tests to determine the influence of subsequent ammonia fumigation on the efficacy of the fungicide imazalil (IMZ; 44.6\% imazalil, Fungaflor 500EC; Janssen Pharmaceutica, Beerse, Belgium), lower than commercial rates of IMZ and all tested dosages of ammonia, that partially controlled green mold and blue mold, were employed in order to reveal the interaction between these treatments. The fruit were inoculated as previously described with $P$. digitatum PD90 or $P$. italicum. IMZ treatments were applied by dipping the fruit for $30 \mathrm{~s}$ in aqueous solutions of 0 (control), 10, 15,30, or $45 \mathrm{mg} \mathrm{L}^{-1}$ of IMZ at room temperature. Fruit were not rinsed and were allowed to dry in air at approximately $20^{\circ} \mathrm{C}$. After 24 hours, they were fumigated with ammonia and incubated as previously described.

\subsection{Influence of ammonia fumigations on $\mathrm{pH}$ of fruit albedo.}

The $\mathrm{pH}$ of fruit albedo in contact with ammonia gas was measured before and after three fumigations, two of them with oranges and one with lemons, to assess the alteration in $\mathrm{pH}$. Two pieces of fruit were used for each concentration of ammonia tested (initial applied dosages of 0,1500 , 3000 , or $6000 \mu \mathrm{L} \mathrm{L}^{-1}$ ). Before ammonia fumigation, the fruit were wounded on 3 points in the equatorial zone by cutting the flavedo with the tip of a knife leaving an open albedo area of $5 \mathrm{~mm}$ in diameter and 2 $\mathrm{mm}$ in depth. A $\mathrm{pH}$ meter with a $2 \mathrm{~mm}$ diameter combination electrode with automatic temperature compensation (' 3 in 1'; Corning Incorporated Science Products Division, Corning, NY, USA) was used. A volume of $30 \mu \mathrm{l}$ of distilled water was added to each wound before measuring the $\mathrm{pH}$. The $\mathrm{pH}$ was measured immediately before the fumigations, immediately afterwards, and $24 \mathrm{~h}$ later. 
2.6. Influence of ammonia fumigation on the natural degreening rate of lemons

Dark green lemons were randomized and divided in two sets of 20 fruit each; one set was stored at $20^{\circ} \mathrm{C}$ and the second one was fumigated with an initial applied dosage of $6000 \mu \mathrm{L} \mathrm{L}^{-1}$ ammonia for $6 \mathrm{~h}$ at $22^{\circ} \mathrm{C}$. A colorimeter (Chromameter CR-300 Minolta Co. Ltd, Osaka, Japan) was used to measure the rind surface color using CIE color parameters $\mathrm{L}^{*}$ (lightness), $\mathrm{C}^{*}$ (chroma or saturation) and $\mathrm{h}^{\circ}$ (hue angle). The fruit were stored at $20^{\circ} \mathrm{C}$. Color was determined initially before ammonia fumigation and after 12, 20, and 22 days of storage.

\subsection{Statistical analysis}

Combinations of IMZ and ammonia fumigation were applied to three replicates of 20 oranges or lemons. Fruit were randomized before each experiment. Values recording disease incidence were arcsine transformed (arcsin of the square root of the proportion of infected fruit) before an analysis of variance was applied (Statgraphics Plus 4.1, Manugistics Inc., Rockville, MD, USA) and means were separated by Fisher's least significant difference test (LSD; $P=0.05$ ). Values shown are nontransformed data. In order to determine if the effectiveness of the combination of IMZ and ammonia fumigation was synergistic, Limpel's formula was applied (Richter, 1987). Experiments were repeated twice or more and data shown are means of all of the experiment 


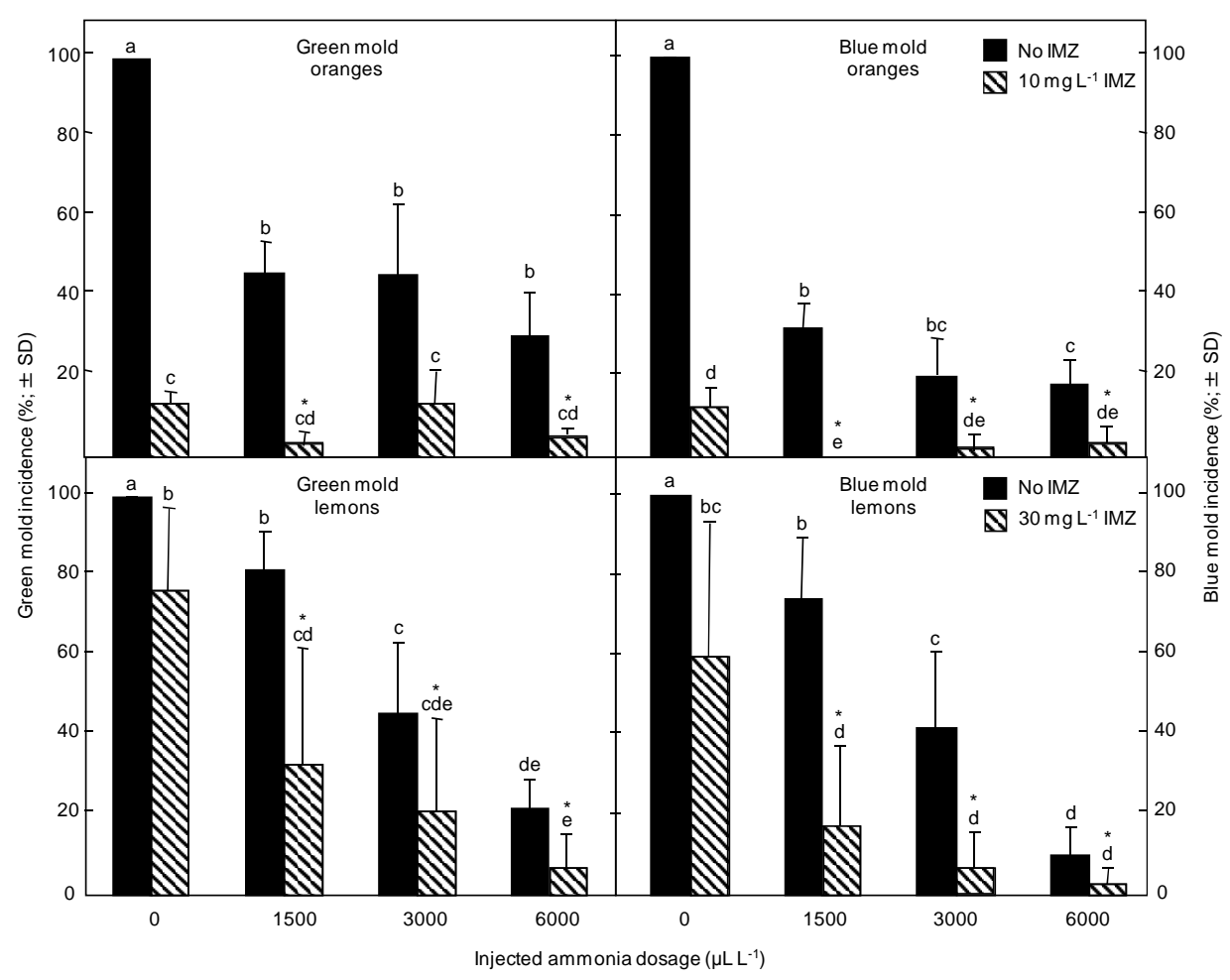

Fig. 1. Effectiveness of fumigation with one injection of ammonia on the incidence of green mold, caused by Penicillium digitatum isolate PD90, an imazalil (IMZ) sensitive isolate, and blue mold, caused by $P$. italicum, respectively, on Eureka lemons. The fruit were inoculated $24 \mathrm{~h}$ before treatment. Fumigation was for a period of $6 \mathrm{~h}$ at $22^{\circ} \mathrm{C}$ with ammonia dosages of $0,1500,3000$, or $6000 \mu \mathrm{L} \mathrm{L}^{-1}$ injected once at the beginning of the treatment. The incidence of infected fruit was determined after storage at $20^{\circ} \mathrm{C}$ for 10 and 7 days, respectively, for green mold and blue mold. Incidence of postharvest green and blue molds, caused by Penicillium digitatum, and P. italicum, respectively, on Eureka lemons incubated at $20^{\circ} \mathrm{C}$ for 10 and 7 days, respectively. Values within each disease with unlike letters are significantly different by Fisher's Protected LSD test $(P \leq 0.05)$. Asterisk indicates synergistic activity was present between ammonia and imazalil according to Limpel's formula (Richter, 1987). 


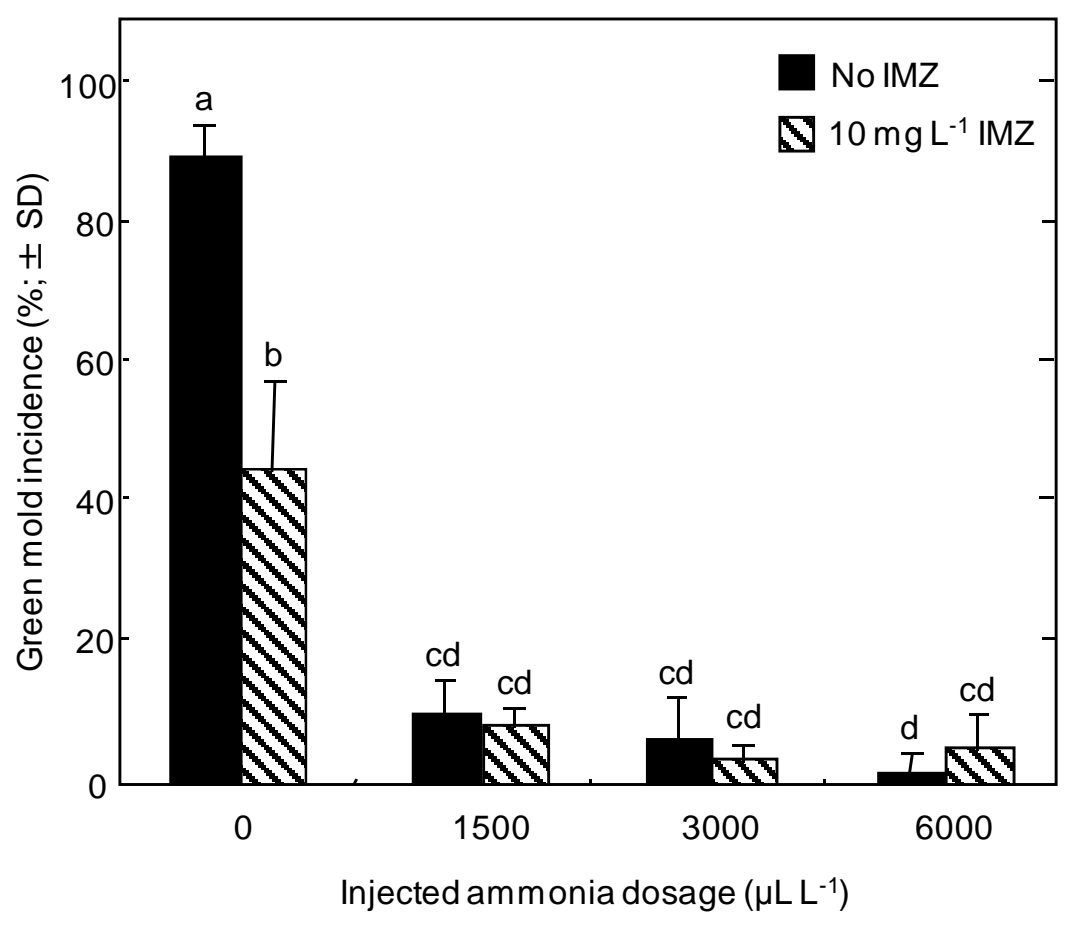

Fig. 2. Incidence of postharvest green mold, caused by Penicillium digitatum (isolate D201) with a high level of imazalil (IMZ) resistance, on Valencia oranges incubated at $20^{\circ} \mathrm{C}$ for 10 days after fumigation for $6 \mathrm{~h}$ at $22^{\circ} \mathrm{C}$ with ammonia dosages of $0,1500,3000$, or $6000 \mu \mathrm{L} \mathrm{L}^{-1}$, injected once at the beginning of treatment. The fruit were inoculated $24 \mathrm{~h}$ before treatment. Values with unlike letters are significantly different by Fisher's Protected LSD test $(P \leq 0.05)$.

\section{Results}

\subsection{Control of green and blue molds}

The incidence of green and blue molds was significantly lower on oranges and lemons treated with a single injection of ammonia gas than on non-treated fruit. In the case of oranges, control of the molds was evident even at the lower concentrations tested (Fig. 1). While non- 
treated fruit were completely decayed at the end of the incubation period, after 10 days of incubation the incidence of green mold on oranges treated with ammonia at any of the tested concentrations was about $40 \%$, and the incidence of blue mold was 26,18 , and $15 \%$ on oranges treated with 1500,3000 , and $6000 \mu \mathrm{L} \mathrm{L}^{-1}$ ammonia, respectively. On lemons, the effectiveness of ammonia fumigations on decay was lower and more dependent on the concentration used. After incubation for 7 days, the incidence of green mold on lemons treated with 1500,3000 , or $6000 \mu \mathrm{L}$ $\mathrm{L}^{-1}$ ammonia was 82,46 , and $22 \%$, and the incidence of blue mold was 74,42 , and $10 \%$, respectively. The incidence of green and blue molds on lemons treated with IMZ alone was relatively high and the combination of IMZ with ammonia was consistently synergistic and it greatly reduced the incidence of both molds compared to lemons treated with either of the treatments alone (Fig. 1). The incidence of green mold on non-treated oranges inoculated with the IMZ-resistant isolate D201 was 90\% after 10-days incubation (Fig. 2). Green mold developed on $45 \%$ of the oranges inoculated with this isolate and treated with $30 \mathrm{mg} \mathrm{L}^{-1} \mathrm{IMZ}$, while treatments with ammonia or combinations of $30 \mathrm{mg} \mathrm{L}^{-1}$ of IMZ with ammonia fumigation reduced the incidence of green mold to less than $10 \%$, and as low as $2 \%$ on oranges treated with $6000 \mu \mathrm{L} \mathrm{L}^{-1}$ ammonia. No synergy between IMZ and ammonia fumigation was observed at any of the concentrations used (Fig. 2). Sporulation of green and blue molds on decayed fruit was similarly reduced by ammonia treatments, although on oranges inoculated with P. digitatum D201 the reduction in sporulation caused by ammonia treatment was greater than that observed with the other isolates (data not shown). Ammonia fumigation did not visibly damage oranges; however, on lemons, albedo tissue within wounds made before fumigation was darker in color after treatments with 3000 or $6000 \mu \mathrm{L} \mathrm{L}^{-1}$ of ammonia. A second injection with the same concentration of ammonia $2 \mathrm{~h}$ after the first injection consistently improved the effectiveness of the fumigations, but it increased tissue darkening on lemons. The incidence of green and blue molds was very low (less than 5\%) or absent on fruit treated with $30 \mathrm{mg}$ $\mathrm{L}^{-1}$ of IMZ before two injections of ammonia at any of the concentrations applied (Fig. 3). Darkening within the albedo tissue of wounds on lemons after a double injection of ammonia was noticeable when $3000 \mu \mathrm{L} \mathrm{L}^{-1}$ of ammonia was used, and the damage was more severe after one or two 
injections of $6000 \mu \mathrm{L} \mathrm{L}^{-1}$ ammonia (Table 1). The albedo tissue in wounds on oranges treated with two injections of $6000 \mu \mathrm{L} \mathrm{L}^{-1}$ of ammonia was darkened slightly.

\subsection{Ammonia concentration within chambers}

Ammonia concentration in the chambers decreased rapidly after the initial injection and the rate of decline slowed as the ammonia concentration diminished. Ammonia concentration in the chambers had declined to $10 \%$ of the initial concentration $2 \mathrm{~h}$ after the injection (Fig. 4). When a second ammonia injection was made $2 \mathrm{~h}$ later, the ammonia concentration reached a higher peak, due to the addition to the amount of ammonia still present in the chamber, and the following drop in the concentration was similarly rapid as after the first injection (Fig. 4). The weight of the fruit treated in each chamber was $20 \pm 3 \mathrm{~kg}$. The rate of ammonia decline in the chamber was influenced by the load of fruit within the chamber (Fig. 5). Initial concentrations of $6000 \mu \mathrm{L} \mathrm{L}^{-1}$ ammonia declined after $2 \mathrm{~h}$ to $4000,3500,2500$, or $600 \mu \mathrm{L} \mathrm{L}^{-1}$ ammonia within chambers containing none, 3,10 , or $20 \mathrm{~kg}$ of non-wounded fruit, respectively. After $2 \mathrm{~h}$ the rate of decline in ammonia concentration was slower (Fig. 5). The C-T products calculated from the ammonia concentrations measured in this experiment and the observations of their effect on fruit appearance were summarized (Table 1). 


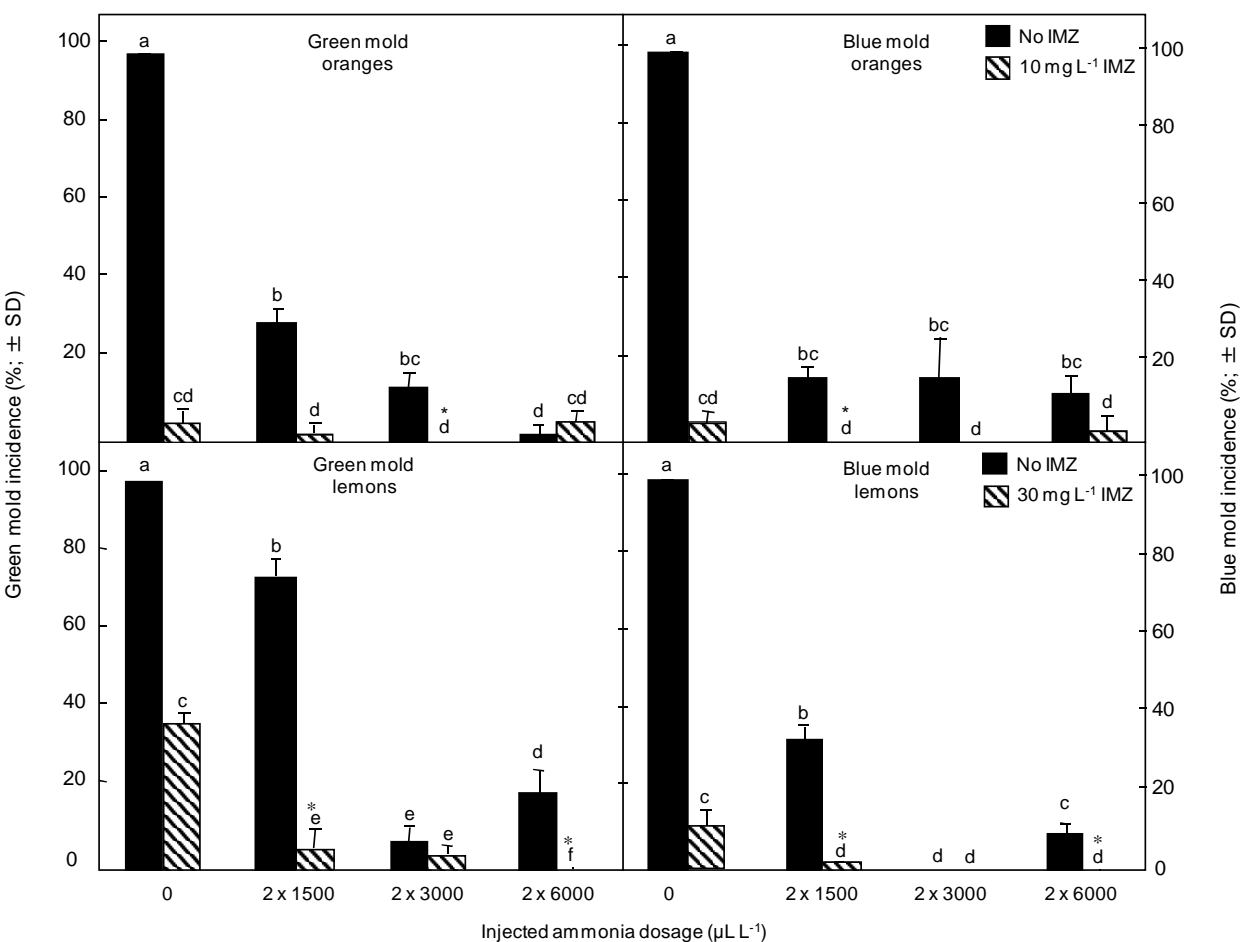

Fig. 3. Effectiveness of fumigation with two injections of ammonia on the incidence of green mold, caused by Penicillium digitatum (isolate D90, imazalil (IMZ) sensitive), and blue mold, caused by P. italicum, respectively, on Valencia oranges $(\mathrm{A}, \mathrm{B})$ and Eureka lemons $(\mathrm{C}, \mathrm{D})$. The fruit were inoculated $24 \mathrm{~h}$ before treatment. Fumigation was for a period of $6 \mathrm{~h}$ at $22^{\circ} \mathrm{C}$ with ammonia dosages of $0,1500,3000$, or 6000 $\mu \mathrm{L} \mathrm{L}^{-1}$ injected at the beginning of the treatment and again $2 \mathrm{~h}$ later. The incidence of infected fruit was determined after storage at $20^{\circ} \mathrm{C}$ for 10 and 7 days, respectively, for green mold and blue mold. Values within panel with unlike letters are significantly different by Fisher's Protected LSD test $(P \leq 0.05)$. Asterisk indicates synergistic activity was present between ammonia and imazalil according to Limpel's formula. 


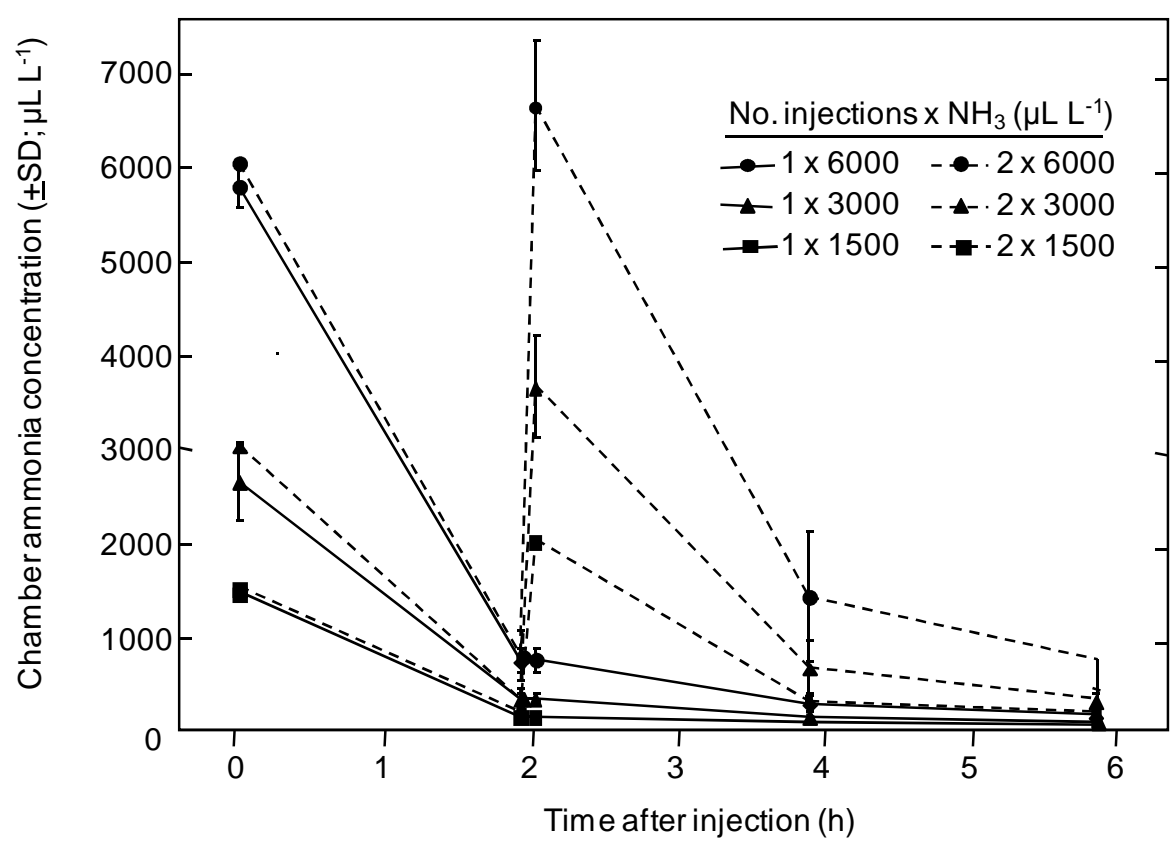

Fig. 4. Concentration of ammonia gas during fumigations in chambers with ammonia dosages of 1500,3000 , or $6000 \mu \mathrm{L} \mathrm{L}^{-1}$ injected at the beginning of the treatment $(1500,3000,6000)$ or at the beginning of the treatment and again $2 \mathrm{~h}$ later $(2 \times 1500,2 \times 3000,2 \times 6000)$. 


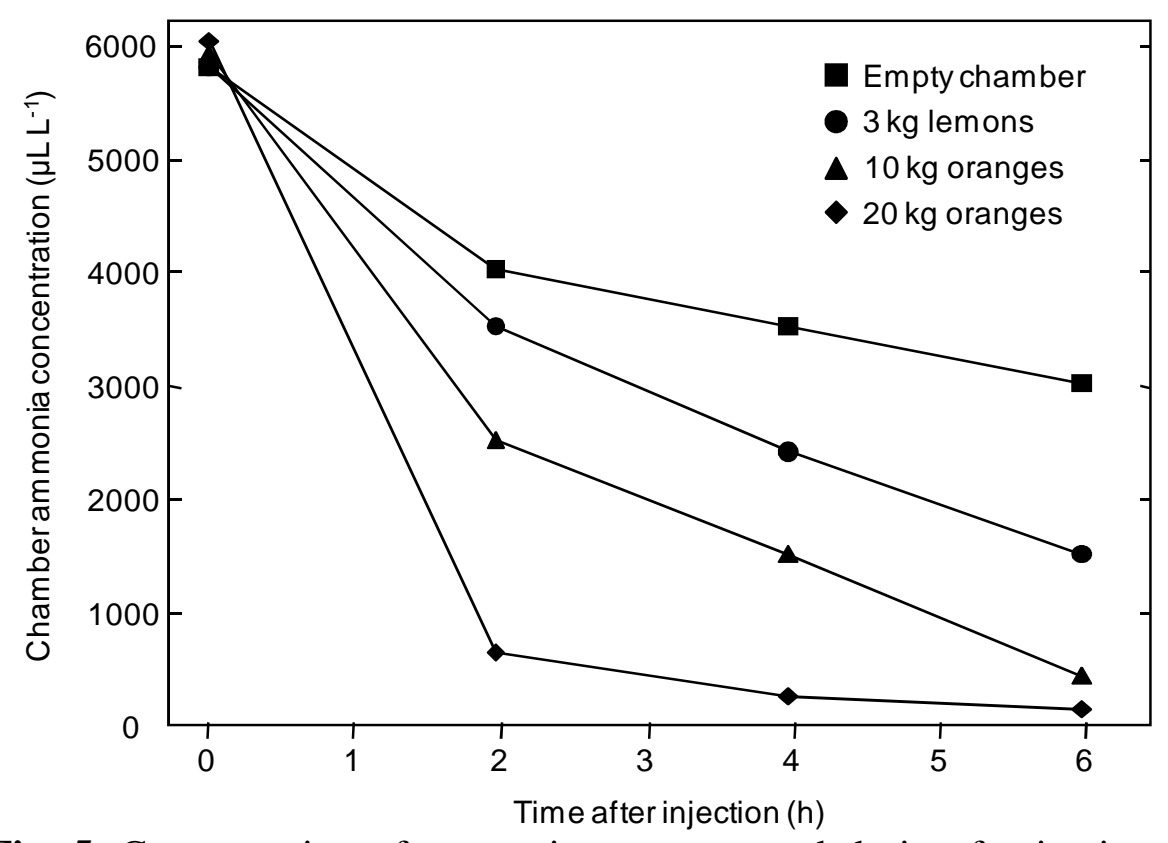

Fig. 5. Concentration of ammonia gas measured during fumigations with one injected dosage of ammonia at $6000 \mu \mathrm{L} \mathrm{L}^{-1}$ in chambers loaded with 0 (empty), 3, 10, or $20 \mathrm{~kg}$ of fruit.

\subsection{Influence of ammonia fumigations on germination of conidia}

Fumigations with injected concentrations of 1500,3000 , or $6000 \mu \mathrm{L} \mathrm{L}^{-1}$ of ammonia for $6 \mathrm{~h}$ inhibited the subsequent germination of conidia of $P$. digitatum isolate D90 from $97 \%$ to approximately 75 to $80 \%$ (Fig. 6). Two injections with the same dosage of ammonia gas inhibited the germination of conidia to between 45 to $70 \%$. Germination of the conidia of $P$. digitatum isolate D201 was reduced from $98 \%$ to $43 \%$ by one injection of $6000 \mu \mathrm{L} \mathrm{L}^{-1}$ of ammonia gas, and further reduced germination to $19 \%$ by a second injection (Fig. 6). P. italicum was the more sensitive to ammonia than $P$. digitatum; a single injection of 6000 $\mu \mathrm{L} \mathrm{L}^{-1}$ of ammonia reduced the germination of its conidia from $99 \%$ to $22 \%$, and further reduced germination to $11 \%$ by a second injection (Fig. $6)$. 


\subsection{Influence of ammonia fumigations on $\mathrm{pH}$ of fruit albedo}

The $\mathrm{pH}$ of citrus albedo in contact with ammonia gas was significantly increased by the fumigations. Exposure of albedo to higher concentrations of ammonia significantly increased the difference between its $\mathrm{pH}$ before and after treatments. The $\mathrm{pH}( \pm \mathrm{SD})$ of the albedo of citrus fruit before fumigation was $5.9( \pm 0.3)$, while after fumigations with 1500,3000 , or $6000 \mu \mathrm{L} \mathrm{L}^{-1}$ ammonia it was $6.5( \pm 0.3), 6.8( \pm 0.4)$, or 7.2 $( \pm 0.3)$, respectively. When the $\mathrm{pH}$ was measured in the same wounds 24 $\mathrm{h}$ after treatment, they had declined and were not significantly different than those measured before the fumigations (data not shown). 


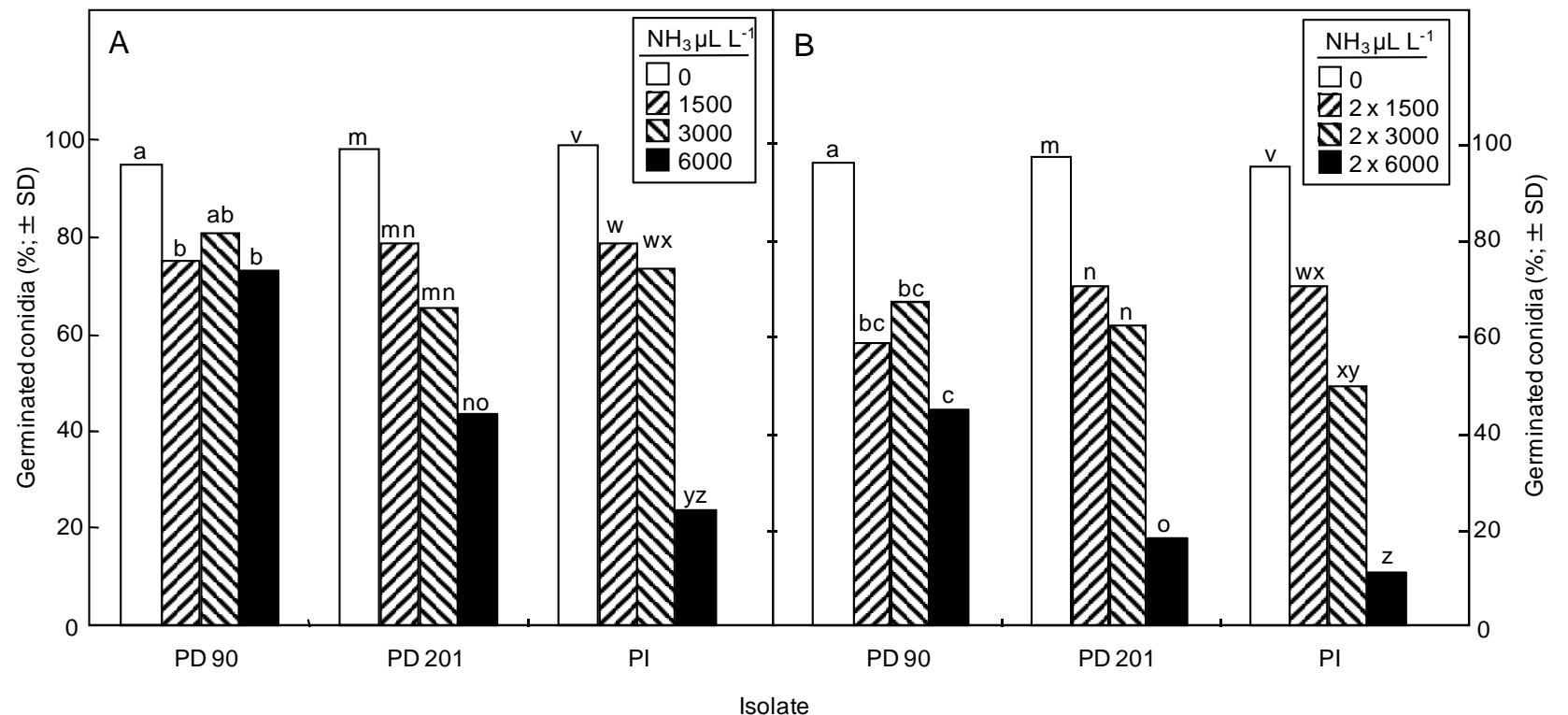

Fig. 6. Germination of conidia of Penicillium digitatum (imazalil-sensitive isolate PD90 and imazalilresistant isolate PD201) and P. italicum (PI) after fumigation for $6 \mathrm{~h}$ at $22^{\circ} \mathrm{C}$ with dosages of 0,1500 , 3000 , or $6000 \mu \mathrm{L} \mathrm{L}^{-1}$ of ammonia injected only at the beginning of the treatment (A) or at the beginning and again after $2 \mathrm{~h}(\mathrm{~B})$. Germination was determined after incubation for $12 \mathrm{~h}$ at $25^{\circ} \mathrm{C}$ on potato dextrose agar. Values within each isolate, fumigated by a single or double injection of ammonia, with unlike letters are significantly different by Fisher's Protected LSD test $(P \leq 0.05)$. Each value is the mean from three experiments of three replicates of 150 to 200 conidia each. 
Table 1. Applied ammonia dose, fruit load, measured concentration-time products (C-T), presence of fresh wounds before fumigation, and rind appearance after the fumigation of lemons or Valencia oranges.

\begin{tabular}{|c|c|c|c|c|c|}
\hline \multirow{2}{*}{$\begin{array}{c}\mathrm{NH}_{3}{ }^{\mathrm{a}} \\
\left(\mu \mathrm{LL}^{-1}\right)\end{array}$} & \multirow{2}{*}{$\begin{array}{l}\text { Fruit load } \\
\qquad(\mathrm{kg})\end{array}$} & \multirow{2}{*}{$\begin{array}{l}\text { C-T product }{ }^{b} \\
\left(\mu \mathrm{L} \mathrm{L}^{-1} \mathrm{~h}^{-1}\right)\end{array}$} & \multirow{2}{*}{$\begin{array}{l}\text { Wounded }{ }^{c} \\
\text { (yes or no) }\end{array}$} & \multicolumn{2}{|c|}{ Rind appearance } \\
\hline & & & & Oranges & Lemons \\
\hline $2 \times 1500$ & 20 & 3303 & yes & unaltered & unaltered \\
\hline $2 \times 3000$ & 20 & 8564 & yes & unaltered & Tissue slightly darker in wounds \\
\hline $2 \times 6000$ & 20 & 16960 & yes & Tissue slightly darker in wounds & Tissue much darker in wounds \\
\hline $1 \times 1500$ & 20 & 1770 & yes & unaltered & unaltered \\
\hline $1 \times 3000$ & 20 & 3650 & yes & unaltered & unaltered \\
\hline $1 \times 6000$ & 20 & 7953 & yes & unaltered & Tissue much darker in wounds \\
\hline $1 \times 6000$ & 20 & 7830 & no & unaltered & ND \\
\hline $1 \times 6000$ & 10 & 14320 & no & unaltered & ND \\
\hline $1 \times 6000$ & 3 & 19100 & no & ND & unaltered \\
\hline $1 \times 6000$ & 0 & 23800 & no & NA & NA \\
\hline
\end{tabular}

${ }^{\mathrm{a}}$ Number of injections and calculated concentration of ammonia applied into the chamber. When a second injection was made, it followed the first injection by $2 \mathrm{~h}$.

${ }^{b}$ Measured concentration times time product during fumigation.

${ }^{c}$ Fresh wounds were made at 3 points in the equatorial zone by cutting the flavedo to expose an albedo area of $5 \mathrm{~mm}$ in diameter and $2 \mathrm{~mm}$ in depth immediately before fumigation. 
Table 2. Color parameters of lightness $\left(\mathrm{L}^{*} ; \pm \mathrm{SD}\right)$, chroma or saturation $(\mathrm{C} ; \pm \mathrm{SD})$, and hue angle $\left(h^{\mathbf{0}} ; \pm \mathrm{SD}\right)$ measured on non-treated lemons (control) and on lemons fumigated with $6000 \mu \mathrm{L} \mathrm{L}^{-1}$ before $(0)$ and 12,20 , and 22 days after fumigation and storage at $20^{\circ} \mathrm{C}$.

\begin{tabular}{|c|c|c|c|c|c|c|}
\hline \multirow{2}{*}{$\begin{array}{l}\text { Days after } \\
\text { fumigation }\end{array}$} & \multicolumn{3}{|c|}{ Untreated } & \multicolumn{3}{|c|}{ Ammonia fumigated } \\
\hline & $\mathrm{L}^{*}$ & $\mathrm{C}$ & $h^{\circ}$ & $\mathrm{L}^{*}$ & $\mathrm{C}$ & $h^{\mathrm{o}}$ \\
\hline 0 & $50.2(0.6)$ & $39.3(0.4)$ & $117.7(0.5)$ & $53.2(3.0)$ & $42.6(2.4)$ & $115.9(1.4)$ \\
\hline 12 & $52.7(0.3)$ & $46.0(0.9)$ & $114.2(0.3)$ & $59.4(2.6)$ & $48.0(0.7)$ & $108.6(0.7)$ \\
\hline 20 & $54.7(4.8)$ & $45.9(4.5)$ & $113.1(3.0)$ & $61.0(4.7)$ & $47.8(2.7)$ & $106.7(3.5)$ \\
\hline 22 & $59.1(5.2)$ & $49.2(4.0)$ & $108.0(3.7)$ & $62.4(4.8)$ & $48.1(3.2)$ & $102.6(4.5)$ \\
\hline
\end{tabular}


A decrease in hue angle $\left(h^{0}\right)$, which indicates the transition from green to yellow color, was recorded for untreated and ammonia-fumigated lemons between days 0 and 22 of storage. On untreated lemons, hue angle values measured after 12, 20, and 22 days were 3.5, 4.6, and 8.8 degrees lower than the initial value, respectively. On lemons fumigated with $6000 \mu \mathrm{L} \mathrm{L}^{-}$ ${ }^{1}$ ammonia, hue values measured after 12, 20, and 22 days were 7.3, 9.1, and 13.2 lower, respectively (Table 2). At each time of measurement, the decrease of the hue values was significantly larger on lemons treated with ammonia than on untreated lemons. The parameters measuring lightness $\left(\mathrm{L}^{*}\right)$ and saturation $\left(\mathrm{C}^{*}\right)$ changed similarly on fumigated and untreated lemons. No injury was observed on the lemons used in this experiment.

\section{Discussion}

Fumigation of citrus fruit with ammonia effectively controlled postharvest green and blue molds. Generally, it controlled blue mold better than green mold, and it was more effective on oranges than on lemons. The inhibitory activity of ammonia increased as the concentration applied increased and a double injection of ammonia further improved its effectiveness. These results corroborate the findings in prior reports (Gunther et al., 1959A; Leggo and Seberry, 1964; Roistacher, et al., 1955; Roistacher, et al., 1957; Roistacher, et al., 1958; Tomkins and Trout, 1931). Citrus fruit tolerate ammonia gas well, unlike many other fresh commodities (Phillips, 1985). Bottini (1927) first used ammonia gas, sublimed from ammonium bicarbonate, to control green and blue molds and diplodia stem end rot, caused by Lasiodiplodia theobromae (Pat.) Griffon \& Maubl., on citrus fruit. Control of ammonia gas concentration from sublimed salts was difficult and rind injury of oranges occurred and this approach was not implemented for this reason (Eckert, 1967; Tomkins and Trout, 1931; Grasovsky and Shiff, 1934). Later, ammonia was applied as a fumigant from compressed cylinders where control of its concentration was facilitated. Constant storage in 50 to $200 \mu \mathrm{L} \mathrm{L}^{-1}$ of ammonia controlled decay and stopped sporulation from decay lesions yet did not injure the fruit rind, although rind defects occurred and the calyxes were darkened in some lots (Eckert, 1967). In most prior studies, ammonia was used for relatively long periods, from 2 
to 14 days. Only Roistacher and coworkers $(1955 ; 1957 ; 1958)$ evaluated briefer treatments, and found a single shorter treatment $(9-10 \mathrm{~h})$ with an ammonia concentration of $100 \mu \mathrm{L} \mathrm{L}^{-1}$ controlled green and blue molds. Effective ammonia C-T products were 500 to $3000 \mu \mathrm{L} \mathrm{L}^{-1} \mathrm{~h}^{-1}$, while injuries occurred with higher C-T products (Roistacher et al., 1957). However, the application of this low concentration of ammonia constantly during treatment, as suggested by Roistacher and coworkers (1957), entailed repeated measurements and ammonia injections and special equipment was required for this task. In order to facilitate its commercial adoption, ammonia fumigation should be as uncomplicated and brief as possible, so we evaluated single or double injection ammonia applications for periods of six hours.

On Valencia oranges, treatments with double injections and higher dosages of ammonia more effectively controlled green and blue molds than single injections and lower dosages. When comparing fumigations with similar C-T products, i.e., $3303 \mu \mathrm{L} \mathrm{L}^{-1} \mathrm{~h}^{-1}$ of ammonia from two injections of $1500 \mu \mathrm{L} \mathrm{L}^{-1} \mathrm{~h}^{-1}$ of ammonia compared to $3650 \mu \mathrm{L} \mathrm{L}^{-1} \mathrm{~h}^{-1}$ of ammonia from a single injection of $3000 \mu \mathrm{L} \mathrm{L}^{-1}$, double injections of a lower concentration more effectively controlled decay than a single injection of a higher dose. Roistacher and coworkers (1957) reported repeated dosages of the gas were believed to be more effective than single injections, and that it should be applied within 24 to 30 -h after harvest, before the pathogens had penetrated into the rind to a depth no longer reachable by the gas. In the initial treatment, they speculated ammonia concentrations that were lethal to moist conidia within wounds may not have been sufficient to inhibit the relatively dry conidia not within wounds. Later, in the moist storage environment, most of the conidia were sufficiently hydrated to be controlled by the second ammonia dose. In the present work with Eureka lemons, double injections were always more effective than single ones, but higher dosages were not always more effective. Lemons were apparently damaged by treatments with single $\left(\mathrm{C}-\mathrm{T}\right.$ product $\left.=7953 \mu \mathrm{L} \mathrm{L}^{-1} \mathrm{~h}^{-1}\right)$ or double injections of $6000 \mu \mathrm{L} \mathrm{L}^{-1}$ of ammonia while the tissue darkening in wounds was absent or minor after treatments with two injections of $3000 \mu \mathrm{L} \mathrm{L}^{-1}$ of ammonia $\left(\mathrm{C}-\mathrm{T}\right.$ product $\left.=8564 \mu \mathrm{L} \mathrm{L}^{-1} \mathrm{~h}^{-1}\right)$. This shows the sensitivity of Eureka lemons to single high concentrations of $6000 \mu \mathrm{L} \mathrm{L}^{-1}$ 
of ammonia was greater than to a similar C-T delivered by two injections with lower ammonia concentrations.

Risk of product injury must be established for any horticultural fumigant. Ammonia fumigations did not harm fruit with blemish-free rinds, but the exposed albedo tissue of wounded fruit darkened. The rind of Eureka lemons was more sensitive to ammonia fumigations than that of Valencia oranges. The rate of natural transition of green to yellow color of lemons was slightly accelerated by ammonia fumigation. Wounds in lemon rinds that exposed the albedo became dark brown in color after exposure to one or two injections of $6000 \mu \mathrm{L} \mathrm{L}^{-1}$ of ammonia, while the same treatment applied to Valencia oranges caused only a slight browning of this tissue. Similar injuries were described by Roistacher and coworkers (1957) on lemons and navel oranges treated with two daily injections of $5000 \mu \mathrm{L} \mathrm{L}^{-1}$ of ammonia applied daily for 4 days. Tomkins and Trout (1931) observed that neither the appearance nor taste of oranges treated with $1000 \mu \mathrm{L} \mathrm{L}^{-1}$ of ammonia was impaired; however, after storage for 15 days, a treatment with $2000 \mu \mathrm{L} \mathrm{L}^{-1}$ of ammonia caused considerable damage to the fruit. Leggo and Seberry (1964) observed no injuries on the rinds of Washington Navel oranges treated with $6000 \mu \mathrm{L} \mathrm{L}^{-1}$ of ammonia for $78 \mathrm{~h}$. Injuries reported in both the literature and in this study are primarily peripheral browning of fresh wounds in the rind. This effect could even have a positive aspect, since it makes fruit with injured rinds more visible, which would facilitate their detection and removal on packinglines.

Other aspects of the influence of ammonia on fruit quality were reported. Eaks (1959) examined the effect of repeated $10 \mathrm{~h}$-long, $100 \mu \mathrm{L} \mathrm{L}^{-1}$ ammonia fumigations on respiratory rate, juice composition, and appearance of oranges and lemons. Other than browning of fresh wounds, the only significant change was that premature browning and detachment of the calyxes ('buttons') on lemons, but not oranges, occurred after three weekly ammonia fumigations and subsequent storage for four weeks. Although not observed in our work, harm to the calyx has a negative influence on lemon quality, since intact, green 'buttons' are an important aspect of marketing quality and to retard alternaria stem end rot (Smilanick et al., 2006). Approaches to minimize calyx injury could be pre-treatment of the fruit with IMZ so lower ammonia concentrations could be used, incorporation of a low concentration treatment of 2,4-D 
before ammonia fumigation since $2,4-\mathrm{D}$ prolongs the retention of calyx and is commonly used for that purpose (Smilanick, et al., 2006), or if repeated ammonia fumigation of lemons was avoided.

Ammonia concentrations during fumigation declined rapidly during the first $2 \mathrm{~h}$ after injection, after which in many cases little ammonia remained within the chambers. In empty chambers, about $50 \%$ of the ammonia gas was present at the end of a 6-h fumigation. As the load of fruit increased, a faster decrease in the ammonia concentration occurred. Previous studies reported absorption of ammonia by fruit during fumigation (Gunther et al., 1959B; Roistacher, et al., 1957) and it was deemed temporary since no significant ammonia residues were found in fruit after the treatments. Ammonia is a normal constituent of citrus fruit; Valencia oranges contained about $15 \mu \mathrm{L} \mathrm{L}^{-1}$ in the clarified juice (Nelson et al., 1933). Ammonia at 50 to $700 \mu \mathrm{L} \mathrm{L}^{-1}$ in air induced little, if any, measureable increase in the ammonia content of the fruit of treated citrus. Ammonia sorption was proportional to the ammonia concentration and the temperature of the fruit. Wounded, non-waxed, or immature fruit sorbed ammonia faster than non-wounded, waxed, or mature fruit (Gunther et al., 1959B). Roistacher and coworkers (1957) observed that $\mathrm{C}-\mathrm{T}$ values of ammonia sufficient to cause chemically detectable increases in nitrogen residues in lemons usually resulted in severe fruit burns. Gunther and coworkers (1959B) reported that juice quality and organoleptic tests of ammonia-treated fruit revealed very little ammonia absorption in the juice and it was indistinguishable from juice samples of control fruit by standard quality tests. In our limited organoleptic evaluations, no differences in flavor or aroma were detected.

The mode of action of ammonia to inhibit fungi has not been conclusively determined. Its toxicity to the microsclerotia of Verticillium dahliae increases with increasing $\mathrm{pH}$ and it is fungistatic at sub-lethal concentrations (Tenuta and Lazarovits, 2002). It conceivably inhibits green and blue mold infections by both direct action, due to the toxicity to conidia, and indirect action, by modifying the wound environment where infection occurs. In previous tests on oranges fumigated with ammonia during up to 4 days, a direct toxic effect of ammonia on the pathogens was observed, since many conidia could no longer germinate after fumigation (Leggo and Seberry, 1964; Roistacher et al., 1957). A single injection of $6000 \mu \mathrm{L} \mathrm{L}^{-1}$ of ammonia was lethal to 25,60 , and $80 \%$ 
of conidia of $P$. digitatum isolates D90 and D201 and a $P$. italicum isolate, respectively, and a double injection of ammonia at this concentration further increased mortality. Differences in sensitivity of conidia to ammonia among the isolates may explain why ammonia fumigation controlled green mold caused by $P$. digitatum isolate D201 and blue mold better than they controlled green mold caused by $P$. digitatum isolate D90. Quantification of ammonia toxicity and the influence of humidity on its toxicity to $P$. digitatum and $P$. italicum are needed. However, the reduction in disease incidence by ammonia fumigation was very high and greater than the reduction in conidial germination. This supports the existence of an indirect effect of ammonia to inhibit these pathogens, probably by the induction of changes in the tissues of the wounds where infections are initiated. The $\mathrm{pH}$ of albedo exposed to ammonia through wounds was significantly increased by the fumigation, although the increase was reversible and typical $\mathrm{pH}$ values were recovered one day after treatments. It is conceivable that ammonia imparted a thin layer of alkalinized tissue within the wounds that significantly delayed or stopped infection, while wound healing mechanisms within the rind continued or were even stimulated to retard infection from the surviving conidia. Treatment of several Citrus spp. and cultivars with an alkaline solution of sodium carbonate, which reduced green mold infections by more than $90 \%$, also temporarily raised the $\mathrm{pH}$ of the albedo tissue in wounds about 3 units, altered its structure to a "melted" appearance, and induced the accumulation of the phytoalexin scoparone from four to ten times in the tissue (Venditti et al., 2005). Elevated $\mathrm{pH}$ alone could inhibit the growth of these pathogens. The germination of $P$. digitatum is inhibited at $\mathrm{pH} 8$ and above (Smilanick et al., 2005).

Griffin (1994) stated pH influence on fungi is complex and dependent on the ionization of acids or bases, and that $\mathrm{pH}$ can alter membrane potentials and change their permeability to many substances, including toxic compounds. Local $\mathrm{pH}$ modulation by pathogens may be a common mechanism for increasing their virulence during infection (Prusky et al., 2001). Colonization by Penicillium spp. on citrus and apple fruit, a pathogen that acidifies host tissue, was enhanced by citric acid and retarded by alkalinization with $\mathrm{NaHCO}_{3}$ (Prusky et al., 2004). Penicillium spp. acidify the tissue within lesions on citrus fruit tissue by 
the production of organic acids, mainly citric and gluconic, and by the utilization of ammonium ions that was correlated with an efflux of protons. Tissue $\mathrm{pH}$ was positively correlated with ammonium ion content, and presumably, ammonia fumigation would greatly increase ammonium ion content in this tissue, raise its $\mathrm{pH}$, and retard pathogenesis by acidifying pathogens such as the Penicillium spp.. Citrus fruit pathogens such as Colletotrichum spp. and/or Alternaria alternata, which raise the $\mathrm{pH}$ of lesion tissue by ammonia secretion, may not be controlled by ammonia fumigation.

The combination of IMZ treatment followed by ammonia fumigation was usually additive or synergistic in effectiveness to control green mold; IMZ concentrations as much as 50 times lower than those used commercially effectively controlled the disease. These very low rates would not be recommended; we used them to enable the interaction between these treatments to be evident. Siegel and coworkers (1977) showed the fungicide was more toxic to $P$. italicum at $\mathrm{pH} 7$ than at $\mathrm{pH} 5$, and observed that little IMZ entered the mycelium at $\mathrm{pH} 5$ compared with $\mathrm{pH}$ 7. They ascribed this difference in potency to the charge present on the molecule and concluded that reduced toxicity of IMZ at lower $\mathrm{pH}$, when the molecule is charged, occurs because it is less incorporated into the mycelium. Lukens (1971) reported that neutral forms of fungicides penetrated membranes and were more toxic than charged forms. Relatively small differences in $\mathrm{pH}$ can have a significant effect on the concentration of the neutral (un-dissociated) IMZ (Guan et al., 1989; Siegel, et al., 1977). Above the pKa of IMZ (pH 6.53), the imide nitrogen of the molecule is primarily un-dissociated, the molecule is not charged, and it is more lipophilic and soluble in membranes. At $\mathrm{pH}$ values below the $\mathrm{pKa}$, the imide nitrogen is primarily protonated, the molecule is charged, and it has less lipid solubility and poor penetration into membranes. Smilanick and coworkers (2005) empirically quantified IMZ toxicity associated with $\mathrm{pH}$ and reported increased $\mathrm{pH}$ enhanced both the activity of IMZ to inhibit conidial germination and its effectiveness to control green mold on fruit using an IMZ-sensitive or IMZ-resistant isolates, and in this study, we found in the present study ammonia fumigation increased $\mathrm{pH}$ of the albedo in the wounds markedly. The $\mathrm{pH}$ values we measured within the wounds were 5.9 and 7.2, respectively, before and after ammonia fumigation with an initial dose of $6000 \mu \mathrm{L} \mathrm{L}^{-1}$. 
Applying formulas from Smilanick and coworkers (2005) that predicted IMZ toxicity as a function of $\mathrm{pH}$, in the present study the $\mathrm{EC}_{50}$ of an IMZ-sensitive isolate of $P$. digitatum at $\mathrm{pH} 5.9$ would be $20.0 \times 10^{-3} \mathrm{mg}$ $\mathrm{L}^{-1}$, while at $\mathrm{pH} 7.2$ the $\mathrm{EC}_{50}$ would be reduced to $5.7 \times 10^{-3} \mathrm{mg} \mathrm{L}^{-1}$; an increase in IMZ acivity of approximately three-fold. It is likely that the synergism between ammonia and IMZ treatments occurred in part due to the increase in IMZ toxicity at higher $\mathrm{pH}$ values in the wounds where IMZ is in contact with the pathogens.

Several issues must be addressed before using ammonia as a fumigant. Anhydrous ammonia is classified by the US Department of Transportation as nonflammable (Anon., 2006). However, ammonia vapor in high concentrations (16 to 25 percent by weight in air) will burn, although it is difficult to ignite and will not support combustion after the ignition source is withdrawn. In previous studies, ammonia fumigation and ethylene degreening were compatible (Leggo and Seberry, 1964; Roistacher et al., 1957). Ammonia fumigation could be applied within degreening chambers, either before, after, or perhaps during ethylene degreening, and the treatment would not greatly prolong the time fruit are in the chambers. In the present study, we employed short exposures and the temperatures used during degreening, in order to facilitate their combined use. The existing degreening chambers, present in most of the packinghouses in California and Spain, would need to be modified to contain the gas safely and to resist corrosion. Ammonia, especially in the presence of moisture, reacts with and corrodes copper, zinc, and many alloys (Anon., 2006). Only wood, iron, steel, certain rubbers and plastics, and specific nonferrous alloys resistant to ammonia should be used. In order to establish a standardized procedure to employ ammonia fumigation, further studies on the optimal dosages and methods of application of ammonia gas are needed that account for different citrus species and cultivars, and to account for the fruit load factor within fumigation chambers. Gunther et al. (1959B) suggested the use of fiberboard cartons, which are now the most popular packaging, should be avoided unless the amount of ammonia applied was increased to compensate for their large ammonia sorption capacity. Safe entry into these chambers once ammonia fumigation is complete requires evaluation; since rapid sorption of ammonia occurs, atmospheric release of ammonia may be minimal, although it is likely entrapment of the 
remaining gas would be required. Occasionally, entrapment of sulfur dioxide gas remaining after fumigation of table grapes is done using an alkaline solution in an air-washer (Nelson, 1991); with an acidic solution, similar air scrubbing could be done to entrap remaining ammonia after fumigation before chambers are opened.

\section{Acknowledgements}

We thank the Institut Valencià d'Investigacions Agràries (IVIA, Valencia, Spain) for funding the visit of Clara Montesinos-Herrero to the San Joaquin Valley Agricultural Sciences Center in Parlier (California, USA). We acknowledge the California Citrus Research Board for financial assistance, and thank Franka Gabler and Monir Mansour for review of the manuscript.

\section{References}

Anon. 2006. Ammonia as a Refrigerant. Position Document of the Board of Directors, American Society of Heating, Refrigerating and AirConditioning Engineers, Inc. Atlanta, Georgia. http://www.ashrae.org/docLib/200622793710_347.pdf

Adaskaveg, J.E., Förster, H. 2010. New developments in postharvest registrations for edible horticultural crops and use strategies in the United States. In: Prusky, D., Gullino, M.L., (Eds.), Post-Harvest Pathology. Springer, New York, pp. 107-117.

Bates, R. 2002. Pesticide residues and consumer risk assessments. Pestic. Outlook 13, 142-147.

Bond, E.J. 1984. Manual of fumigation for insect control. FAO Plant Production and Protection Paper 54 of the Food and Agriculture Organization of the United Nations.

Bottini, E. 1927. Sulla concervazione della frutta. Ricerche sperimentali esquite sulle Arancie. Ann. Chim. Appl. 17, 129-163.

Bus, V.G., Bongers, A.J., Risse, L. A. 1991. Occurence of Penicillium digitatum and $P$. italicum resistant to benomyl, thiabendazole, and imazalil on citrus fruit from different geographic origins. Plant Dis. 75, 1098-1100. 
Dezman, D.J., Nagy, S., Brown, G.E. 1986. Postharvest fungal decay control chemicals: treatments and residues in citrus fruits. Residue Rev. 97, 37-92.

Eaks, I.L. 1959. Effect of ammonia gas fumigation on respiratory rate, chemical composition of juice, and general appearance and vitality of lemon and orange fruits. Proc. Am. Soc. Hortic. Sci. 73, 237-241.

Eckert, J.W. 1967. Application and use of postharvest fungicides. In: Torgeson, D.C. (Ed.), Fungicides. An Advanced Treatise. Academic Press, New York, pp. 287-378.

Eckert, J.W., Eaks, I.L. 1989. Postharvest disorders and diseases of citrus fruits. In: Reuter, W., Calavan, E.C., Carman, G.E. (Eds.), The Citrus Industry. Berkeley, California: Division of Agriculture and Natural Resources, University of California Press, pp. 179-260.

Grasovsky, A., Shiff, M. 1934. The effect of ammonium bicarbonate on the storage of oranges. Hadar 7, 168-172.

Griffin, D.H. 1994. Spore dormancy and germination. Pages 375-398 in: Fungal physiology, 2nd ed. Wiley-Liss, Inc., New York.

Guan, J., Kerkenaar, A., de Waard, M.A. 1989. Effects of imazalil on sterol composition of sensitive and DMI-resistant isolates of Penicillium italicum. Neth. J. Plant Pathol. 95, 73-86.

Gunther, F.A., Blinn, R.C., Barkley, J.H., Kolbezen, M.J., Staggs, E.A. 1959A. Fungicides for packaged foods, generation of ammonia for inpackage fumigation of foodstuffs. J. Agric. Food Chem. 7, 489-496.

Gunther, F.A., Blinn, R.C., Kolbezen, M.J., Conkin, R.A., Wilson, C.W. 1959B. Fungicides for package foods, sorption of ammonia by fruits, vegetables, eggs, and fiberboard in dynamic systems. J. Agric. Food Chem. 7, 496-502.

Holmes, G.J., Eckert, J.W. 1999. Sensitivity of Penicillium digitatum and $P$. italicum to postharvest citrus fungicides in California. Phytopathology 89, 716-721.

Kinay, P., Mansour, M.F., Gabler, F.M., Margosan, D.A., Smilanick, J. L. 2007. Characterization of fungicide-resistant isolates of Penicillium digitatum collected in California. Crop Prot. 26, 647-656.

Leggo, D., Seberry, J.A. 1964. Ammonia fumigation for reducing green mould wastage in oranges during ethylene degreening. Austral. J. Exp. Agric. Anim. Husb. 4, 173-177. 
Lukens, R.J. 1971. Chemistry of Fungicidal Action. Springer-Verlag, New York.

Nelson, E.K., Mottern, H.H., Eddy, C.W. 1933. Nitrogenous constitu ents on Florida Valencia orange juice. Fruit Prod. J. 12, 231-235, 250.

Montesinos-Herrero, C., Palou, L. 2010. Combination of physical and low-toxicity chemical postharvest treatments for integrated disease management of citrus fruit: a review. Stewart Postharvest Rev. 2010 1,1

Montesinos-Herrero, C., del Río, M.A., Pastor, C., Brunetti, O., Palou, L. 2009. Evaluation of brief potassium sorbate dips to control postharvest Penicillium decay on major citrus species and cultivars. Postharvest Biol. Technol. 52, 117-125.

Nelson, K.E. 1991. Quality and preservation of fruits. In: Eskin, N.A.M. (Ed.), The grape. Boca Raton, Florida: CRC Press, pp. 125-167.

Palou, L., Smilanick, J.L., Droby, S. 2008. Alternatives to conventional fungicides for the control of citrus postharvest green and blue moulds. Stewart Postharvest Rev. 2, 1.

Phillips, D.J. 1985. Detecting ammonia injury on stone fruit. Int. J. Refrig. 8, 54-55.

Prusky, D., McEvoy, J.L., Leverentz, B., Conway, W.S. 2001. Local modulation of host $\mathrm{pH}$ by Colletotrichum species as a mechanism to increase virulence. Mol. Plant-Microbe Interact. 14, 1105-1113.

Prusky, D., McEvoy, J.L., Saftner, R.A., Conway, W.S., Jones, R. 2004. Relationship between host acidification and virulence of Penicillium spp. on apple and citrus fruit. Phytopathology 94, 44-51.

Richter, D.L. 1987. Synergism: a patent point of view. Pestic. Sci. 19, 309-315.

Roistacher, C.N., Eaks, I.L., Klotz, L.J. 1955. Ammonia gas to control blue-green mold decay of citrus fruits. Plant Dis. Rep. 39, 202-205.

Roistacher, C.N., Klotz, L.J., Eaks, I.L. 1957. Ammonia gas used in citrus packing plants as fumigant for control of blue-green mold on Valencias, navels and lemons. Calif. Agric. 11, 11-12.

Roistacher, C.N., Klotz, L.J., Kolbezen, M.J., Staggs, E.A. 1958. Some factors in the control of blue-green mold decay of citrus fruit with ammonia. Plant Dis. Rep. 42, 1112-1122. 
Siegel, M.R., Kerkenaar, A., Kaars Sijpesteijn, A. 1977. Antifungal activity of the synthetic fungicide imazalil. Neth. J. Plant Pathol. 83, 121-133.

Smilanick, J.L., Brown, G.E., Eckert, J.W. 2006. Postharvest citrus diseases and their control. In: Wardowski, W.F. Miller, W.M. Hall, D.J., Grierson W. (Eds.), Fresh Citrus Fruits, Second Edition. Florida Science Source, Inc., Longboat Key, FL, USA, pp. 339-396.

Smilanick, J.L., Mansour, M., Gabler, F.M., Sorenson, D. 2008. Control of citrus postharvest green mold and sour rot by potassium sorbate combined with heat and fungicides. Postharvest Biol. Technol. 2008, 47, 226-238.

Smilanick, J.L., Mansour, M.F., Margosan, D.A., Mlikota-Gabler, F., Goodwine, W.R. 2005. Influence of $\mathrm{pH}$ and $\mathrm{NaHCO}_{3}$ on effectiveness of imazalil to inhibit germination of Penicillium digitatum and to control postharvest green mold on citrus fruit. Plant Dis. 89, 640-648.

Tenuta, M., Lazarovits, G. 2002. Ammonia and nitrous acid from nitrogenous amendments kill the microsclerotia of Verticillium dahliae. Phytopathology 92, 255-264.

Tomkins, R.G., Trout, S.A. 1931. The use of ammonia and ammonium salts for the prevention of green mould in citrus. J. Pomol. Hortic. Sci. 9, 257-264.

Venditti, T., Molinu, M.G., Dore, A., Agabbio, M., D'Hallewin, G. 2005. Sodium carbonate treatment induces scoparone accumulation, structural changes, and alkalinization in the albedo of citrus fruits. J. Agric. Food Chem. 53, 3510-3518.

Wardowski, W.F., Miller, W.M., Grierson, W. 2006. Degreening. In: Wardowski, W.F. Miller, W.M. Hall, D.J., Grierson W. (Eds.), Fresh Citrus Fruits, Second Edition. Florida Science Source, Inc., Longboat Key, FL, USA, pp. 277-298. 

Chapter 7

\title{
Relative susceptibility of major commercial orange and mandarin cultivars to postharvest green and blue molds and its relationship with fruit quality attributes
}

\author{
CLARA MONTESINOS-HERRERO ${ }^{1}$, MANUEL ZARZO ${ }^{2}$ \\ and LLUÍS PALOU ${ }^{1}$
}

${ }^{1}$ Laboratori de Patología, Centre de Tecnología Postcollita (CTP)

Institut Valencià d'Investigacions Agràries (IVIA)

46113 Montcada, Valencia, Spain

${ }^{2}$ Grupo de Ingeniería Estadística Multivariante (GIEMA)

Departamento de Estadística Aplicada e Investigación Operativa y

Calidad, Universitat Politècnica de València (UPV)

Camino de Vera, s/n, Edificio 7A, 46022 Valencia, Spain 



\begin{abstract}
Green and blue molds are responsible for the most important losses of citrus fruit after harvest. The development of these diseases was assessed on the most commercially important orange and mandarin cultivars in Spain during four consecutive harvest seasons and associated with fruit external (rind) and internal (juice) quality parameters. Citrus fruit were harvested at commercial maturity, artificially inoculated with Penicillium digitatum or $P$. italicum, and stored at $20^{\circ} \mathrm{C}$ and $90 \% \mathrm{RH}$ for up to 10 days. Fruit susceptibility to green and blue molds was assessed by means of measured variables, viz. disease incidence (\%) and severity (lesion diameter, $\mathrm{mm}$ ) and pathogen sporulation (\%), and calculated parameters, viz. disease severity rate (DSR, $\mathrm{mm} \mathrm{day}{ }^{-1}$ ), disease index (DI, dimensionless), and disease cube diagonal (DCD, dimensionless). The following cultivar ranking of increasing susceptibility to green mold was obtained: Nova, Sanguinelli, Ortanique, Lanelate, Navelate, Fortune, Clemenules, Valencia, W. Navel, Oronules, Clemenpons, Marisol, Salustiana, Hernandina, and Nadorcott. With some exceptions, blue mold susceptibility ranking was similar. Correlation analysis showed that peel texture characteristics were the most influencing quality parameters on the susceptibility of citrus fruit to green and blue molds.
\end{abstract}

\title{
Introduction
}

Green mold caused by Penicillium digitatum (Pers.: Fr.) Sacc. and blue mold caused by $P$. italicum Wehmer are major postharvest diseases of citrus fruit. These pathogens cause the most economically important postharvest losses of citrus in all production areas that, like Spain or California, are characterized by a Mediterranean-type climate with low summer rainfall (Eckert and Eaks, 1989; Palou, 2014). Green mold typically causes larger losses during commercialization because it is predominant at ambient temperatures, but blue mold can be more important when citrus fruit are long-term cold-stored because $P$. italicum grows faster than $P$. digitatum at temperatures of $10^{\circ} \mathrm{C}$ or lower (Plaza et al., 2003). Besides direct fruit losses, postharvest decay can also increase the costs of citrus fruit producers when disease is found in export shipments, the load is rejected and they are charged for transport and handling costs. Losses due to green and blue molds are variable and depend upon cultivar, climate, orchard, harvest and postharvest factors 
(Smilanick et al., 2006). Both $P$. digitatum and $P$. italicum are strict wound pathogens and incipient infections are typically visible only after about 3 days of incubation at room temperatures. A circular area surrounding the infection point appears soft and water-soaked. As the fungus grows, aerial white mycelium develops in the center of the lesion, expands radially and sporulation follows, forming a colored (green or blue) layer of velvety texture. Although visible mixed infections in the same fruit are not uncommon, usually green mold overgrows blue mold on fruits kept at room temperature.

Development of postharvest diseases depends on the relationship between the pathogen, the fruit host, and the environmental conditions. Host reaction can be highly variable depending on genetic traits (species and/or cultivar differences) and physical and physiological characteristics of the fruit when the infection occurs (Palou, 2014). Although no commercial citrus species and cultivars are known to be resistant to green and blue molds, different degrees of susceptibility are commonly observed in commercial conditions. In fact, the susceptibility ranking of various citrus cultivars to postharvest disease often depends more on the perception of packers and other actors involved in the commercialization process than on the results of a systematic study. According to Eckert and Eaks (1989), general susceptibility of citrus fruits to postharvest diseases typically decreases in this order: mandarins, lemons, oranges, and grapefruits. However, Ortuño et al. (2011) found that susceptibility to green mold decreased in this order: grapefruits, lemons, oranges, mandarins and satsumas. In their work, they also studied the relationship between citrus susceptibility to green mold and flavonoid and scoparone accumulation and found an inverse correlation between the degree of susceptibility and the content of some phenolic compounds. On the other hand, some studies have pointed the different efficacy of antifungal treatments alternative to conventional chemical fungicides depending on the citrus species and cultivar to which they were applied (Palou et al., 2001, 2002; Montesinos-Herrero et al., 2009, 2012; Moscoso-Ramírez et al., 2013a,b). There are several studies that showed differences in the susceptibility of different citrus species to certain pathogenic fungi such as Alternaria spp. (Gardner et al., 1986; Peever et al., 2000; Reis et al., 2007)) or Phytophthora citrophthora (Afek and Sztejnberg, 1988). 
The objective of the present study was to investigate the relative susceptibility of different commercially important orange and mandarin cultivars to postharvest green and blue molds, and determine the relationship between this susceptibility and fruit quality attributes.

\section{Materials and Methods}

Fruit. Fifteen of the most representative citrus cultivars commercially cultivated in Spain and worldwide were selected for this study: oranges (Citrus sinensis L. Osbeck) cvs. Lanelate, Valencia, Navelate, Washington Navel, Salustiana, and Sanguinelli; clementine mandarins (Citrus clementina hort. ex Tanaka), cvs. Clemenules (synonyms: Nules, Clementina de Nules), Clemenpons, Hernandina, Marisol, and Oronules; and hybrid mandarins cvs. Fortune $(C$. tangerina Tanaka $\times C$. clementina), Nadorcott (Citrus reticulata Blanco $\times C$. sinensis ; synonym: Afourer), Nova $[C$. clementina $\times(C$. reticulata $\times C$. paradisi McFadyen)], and Ortanique [C. reticulata $\times(C$. sinensis $\times$ C. reticulata), synonym: Topaz]. Fruit were tested during four consecutive harvest seasons, from 2004-2005 to 2007-2008. Each season, all cultivars were tested at least once. For each pathogen, cultivar, and assay, 4 replicates of 10 fruit each were used.

Pathogen inoculation. Penicillium digitatum and P. italicum, isolates NAV-7 and MAV-1, respectively, from the fungal culture collection of autochthonous postharvest pathogens of the IVIA CTP, were cultured on potato dextrose agar (PDA, Sigma-Aldrich Chemical Co., St. Louis, MA, USA) plates at $25^{\circ} \mathrm{C}$. Conidia of each fungus from 7 to 14-day-old cultures were taken from the agar surface with a sterile rod and transferred to a sterile aqueous solution of $0.05 \%$ Tween ${ }^{\circledR} 80$ (Panreac, S.A.U., Barcelona, Spain). Conidial suspensions were filtered through two layers of cheesecloth to separate hyphal fragments and adjusted to a concentration of $10^{6}$ spores $/ \mathrm{mL}$ using a haemocytometer. The tip of a stainless steel rod, $1 \mathrm{~mm}$ wide and $2 \mathrm{~mm}$ in length, was immersed in the conidial suspension and inserted once in the fruit rind afterwards, at the equatorial zone of the fruit. Inoculated fruit were kept in a temperaturecontrolled room at $20^{\circ} \mathrm{C}$ and $90 \% \mathrm{RH}$ for up to 10 days. 
Cultivar susceptibility assessment. Disease incidence (percentage of infected fruit) and severity (diameter of the lesion), and percentage of sporulated lesions on inoculated fruit incubated at $20^{\circ} \mathrm{C}$ and $90 \% \mathrm{RH}$ were evaluated every day. Disease development was further assessed by means of the calculated parameter AUDPC (area under the disease progress curve), by using the following formula:

$$
A_{k}=\sum_{i=1}^{N_{i}-1} \frac{\left(y_{i}+y_{i+1}\right)}{2}\left(t_{i+1}-t_{i}\right)
$$

where $y i$ is the diameter of a lesion at time $t i$, in days, and $y i+1$ is the diameter of the lesion at time $t i+1$, and $\mathrm{N}$ is the total number of observations (Shaner and Finney, 1977).

Other calculated parameters were studied in order to assess fruit susceptibility more accurately. Thus, a disease severity rate (DSR, in $\mathrm{mm}$ /day) was defined by the slope of the regression line of the increment of lesion diameter once the infection was initiated, and accounted for the speed of disease development in infected rind wounds. On the other hand, a disease index (DI), adapted from the McKinney disease index (McKinney, 1923), (was defined as DI $=$ disease incidence $(\%) \mathrm{x}$ AUDPC/100 (dimensionless) to take into account not only disease development but also the onset or not of the infection. Finally, a parameter taking into account disease incidence, AUDPC, and pathogen sporulation, was calculated to rank the cultivars by their overall susceptibility to green and blue molds. This dimensionless parameter was named as disease cube diagonal (DCD) and was calculated by measuring in a graph the length of the line between the origin and the point $(\mathrm{x}, \mathrm{y}, \mathrm{z})$, where $\mathrm{x}$ is incidence (\%), $\mathrm{y}$ is AUDPC, and $\mathrm{z}$ is sporulation (\%).

Fruit quality determination. All citrus cultivars were collected at commercial maturity, with commercial rind color (no artificial degreening was required for early season cultivars), and quality analyses were performed at room temperature within $24 \mathrm{~h}$ after harvest. Peel color was measured using Hunter parameters (L, a, b) with a colorimeter (Model Minolta CR-300, Konica Minolta Business Technologies, Inc., Tokio, Japan). A color index $(\mathrm{CI})$ was calculated: $\mathrm{CI}=1000 \cdot \mathrm{a} / \mathrm{L} \cdot \mathrm{b}$ 
(Jiménez-Cuesta et al., 1981). For each batch, three measurements on the equatorial area of 25 fruit were performed.

Firmness of 20 fruit per batch was determined using an Instron Universal Testing Machine (Model 4301, Instron Corp., Norwood, MA, USA). Each fruit was compressed between two flat surfaces closing together at the rate of $5 \mathrm{~mm} / \mathrm{min}$. The machine gave the deformation (\%) after application of a load of $1 \mathrm{~kg}$ to the equatorial region of the fruit. Results were expressed as percentage of deformation related to initial diameter. Peel break resistance was measured on 20 fruit per batch using the same machine. Each fruit was compressed with a $5 \mathrm{~mm}$ diameter steel rod until the fruit rind was broken, and the necessary pressure or maximum compressive load (kgf) was measured. The thickness ( $\mathrm{mm}$ ) of both the flavedo and the whole rind (flavedo + albedo) was measured at two opposite sites in the equatorial zone of 20 fruit per batch by means of a digital caliper (Pittsburgh Precisition Instruments, Pittsburgh, PA, USA). Peel oil release pressure $(\mathrm{kg})$ of 20 fruit per treatment was determined using a fruit pressure tester with a $8 \mathrm{~mm}$ diameter tip (Model FT327, Facchini, Alfonsine, Italy). Each fruit was wrapped with filter paper and then compressed with the tester until essential oil stains appeared. The necessary pressure (kg) was annotated (Tugwell and Moulds, 1999). For fruit internal quality characterization, the juice from 3 previously weighed samples of 8 fruit each was extracted with a rotatory citrus squeezer and filtered through a $0.8 \mathrm{~mm}$ diameter sieve. The following juice quality parameters were determined: soluble solids content (SSC) was measured with a digital refractometer (Model DR-101, Optic Ivymen System, Barcelona, Spain) and expressed as percentage. Titratable acidity (TA) was determined from a $5 \mathrm{~mL}$ aliquot by titration with $0.1 \mathrm{~N} \mathrm{NaOH}$ with phenolphthalein indicator and results were given as percentage ( $\mathrm{g}$ of citric acid per $100 \mathrm{~mL}$ ). Maturity index (MI) was calculated as the $\mathrm{SSC} / \mathrm{TA}$ ratio. Juice $\mathrm{pH}$ was measured by using a $\mathrm{pH}$ meter (Model S20 SevenEasy ${ }^{\mathrm{TM}} \mathrm{pH}$, Mettler-Toledo, LLC, Columbus, OH, USA). In all cases, two replicated measures were performed with each juice sample. Juice yield was expressed as percentage of juice $(\mathrm{mL})$ per fruit weight (g). 


\section{Data analysis}

Mean disease and fruit quality data from all four seasons were analyzed by analysis of variance (ANOVA) with Statgraphics software (Statgraphics Plus 5.1; Manugistics Inc., Rockville, MA, USA). The level of significance was established at $P=0.05$. Data on disease incidence and pathogen sporulation had been previously transformed to the arcsine of the square root of the proportion of infected or sporulated fruit to assure the homogeneity of variances. When appropriate, the Fisher's Protected Least Significant Difference (LSD) test was used for means separation. Values displayed in graphs are non-transformed means. Pearson correlation coefficients $(r)$ were estimated between mean values of fruit qualitative parameters and disease development parameters, and the $P$ values of such correlations were calculated.

\section{Results and Discussion}

Fruit quality. Marisol and Nadorcott mandarin cultivars were the least firm (7.14 and 6.76\% deformation, respectively) among the fifteen citrus cultivars tested. All oranges showed similar high rind firmness, around $2 \%$ deformation, similar to that of the hybrid cultivar Nova (Table 1). The citrus cultivar with the highest peel break resistance was Sanguinelli orange $(3.59 \mathrm{~kg})$, around $2 \mathrm{~kg}$ higher than that of the rest of cultivars. Peel (flavedo + albedo) thickness strongly marked the difference between oranges $(4.71-5.31 \mathrm{~mm})$ and clementine and hybrid mandarin cultivars $(2.38-2.87 \mathrm{~mm})$, except for the hybrid Nova, which had a slightly but significantly thicker peel $(3.61 \mathrm{~mm})$ than the rest of mandarins. Juice yield was significantly different among citrus cultivars $(P=0.01)$, and the values ranged from 41.41 to $51.10 \mathrm{ml}$ juice $/ 100 \mathrm{~g}$ fruit for Clemenpons and Ortanique citrus cultivars, respectively. Ortanique, Fortune, Marisol, and Valencia cultivars were those with higher juice yield. There was no significant influence of citrus cultivar on the juice SSC $(P=0.07)$. Hernandina clementine showed the lowest TA $(0.66 \%)$, while the most acid juice was that of Sanguinelli oranges $(1.71 \%)$. Juice $\mathrm{pH}$ differences between citrus cultivars were significant $(P=0.0472)$, but values slightly differ from each other and ranged from 2.95 to 3.97 for Ortanique and Hernandina mandarins, respectively. Tested citrus cultivars significantly differed on peel color; Navelate oranges showed the lowest CI value (6.01) and Nova mandarins showed the highest 
(18.16). Peel oil release pressure was markedly different among cultivars; in the case of Marisol mandarins, for instance, peel oil was released after applying a pressure of $2.79 \mathrm{~kg}$, while it was necessary to apply a pressure of $8.04 \mathrm{~kg}$ to break the oil glands of Sanguinelli oranges. Rind quality attributes such as firmness, peel thickness, and peel oil release pressure clearly distinguished oranges from mandarins (Table 1). 
Table 1. At harvest external and internal quality attributes of commercially important orange and mandarin cultivars.

\begin{tabular}{|c|c|c|c|c|c|c|c|c|c|c|}
\hline Cultivar & $\begin{array}{l}\text { Deformation } \\
(\%)\end{array}$ & $\begin{array}{c}\begin{array}{c}\text { Peel break } \\
\text { resistance } \\
(\mathbf{k g})\end{array} \\
\end{array}$ & $\begin{array}{c}\text { Peel } \\
\text { thickness } \\
(\mathbf{m m}) \\
\end{array}$ & $\begin{array}{c}\text { Juice yield (mL } \\
\text { juice/100 g } \\
\text { fruit) } \\
\end{array}$ & SSC ( ${ }^{\circ} B$ rix) & $\begin{array}{c}\text { TA (g citric/ } \\
100 \mathrm{~mL} \text { juice) }\end{array}$ & $\begin{array}{l}\text { Maturity } \\
\text { index }\end{array}$ & Juice pH & Color index & $\begin{array}{c}\text { Peel oil } \\
\text { release } \\
\text { pressure }(\mathrm{kg})\end{array}$ \\
\hline Clemenpons & $4.43 \mathrm{cde}$ & $1.32 \mathrm{abc}$ & $2.65 \mathrm{a}$ & $41.41 \mathrm{ab}$ & $11.74 \mathrm{abc}$ & $0.96 \mathrm{abc}$ & $12.30 \mathrm{bcde}$ & $3.12 \mathrm{ab}$ & $8.36 \mathrm{ab}$ & $3.66 \mathrm{abc}$ \\
\hline Clemenules & $5.44 \mathrm{e}$ & $1.39 \mathrm{abc}$ & $2.83 \mathrm{a}$ & $42.12 \mathrm{a}$ & $12.56 \mathrm{bc}$ & $0.88 \mathrm{ab}$ & $14.71 \mathrm{e}$ & $3.67 \mathrm{~cd}$ & $7.50 \mathrm{ab}$ & $4.03 \mathrm{bc}$ \\
\hline Hernandina & $4.79 \mathrm{de}$ & $1.59 \mathrm{abc}$ & $2.87 \mathrm{ab}$ & $41.63 \mathrm{ab}$ & $13.53 \mathrm{bc}$ & $0.66 \mathrm{a}$ & $20.77 \mathrm{~g}$ & $3.97 \mathrm{~d}$ & $12.74 \mathrm{abcd}$ & $4.28 \mathrm{bcd}$ \\
\hline Marisol & $7.14 \mathrm{f}$ & $0.95 \mathrm{ab}$ & $2.38 \mathrm{a}$ & $48.45 \mathrm{~cd}$ & $11.19 \mathrm{ab}$ & $1.18 \mathrm{bcd}$ & $9.71 \mathrm{abc}$ & & $10.41 \mathrm{abc}$ & $2.79 \mathrm{a}$ \\
\hline Oronules & $5.62 \mathrm{ef}$ & $1.40 \mathrm{abc}$ & $2.62 \mathrm{a}$ & $42.75 \mathrm{abc}$ & $11.56 \mathrm{abc}$ & $1.18 \mathrm{~cd}$ & $9.85 \mathrm{abc}$ & & $9.59 \mathrm{ab}$ & $3.23 \mathrm{ab}$ \\
\hline Fortune & $3.19 \mathrm{abc}$ & $1.43 \mathrm{abc}$ & $2.75 \mathrm{a}$ & $50.45 \mathrm{~d}$ & $14.03 \mathrm{c}$ & $1.36 \mathrm{def}$ & $10.32 \mathrm{abcd}$ & $3.32 \mathrm{abc}$ & $12.30 \mathrm{abcd}$ & 5.44 efg \\
\hline Nadorcott & $6.76 \mathrm{f}$ & $0.93 \mathrm{a}$ & $2.57 \mathrm{a}$ & $44.44 \mathrm{abc}$ & $12.16 \mathrm{abc}$ & $1.12 \mathrm{bcd}$ & $10.92 \mathrm{abcd}$ & $3.41 \mathrm{bc}$ & $17.32 \mathrm{~cd}$ & $3.73 \mathrm{abc}$ \\
\hline Nova & $2.86 \mathrm{ab}$ & $1.74 \mathrm{abc}$ & $3.61 \mathrm{~b}$ & $44.38 \mathrm{abc}$ & $12.67 \mathrm{abc}$ & $0.67 \mathrm{a}$ & $19.01 \mathrm{fg}$ & $3.63 \mathrm{bcd}$ & $18.16 \mathrm{~d}$ & $4.26 \mathrm{cdef}$ \\
\hline Ortanique & $3.33 \mathrm{bcd}$ & $2.26 \mathrm{c}$ & $2.46 \mathrm{a}$ & $51.10 \mathrm{~d}$ & $12.70 \mathrm{abc}$ & $1.62 \mathrm{ef}$ & $7.87 \mathrm{ab}$ & $2.95 \mathrm{a}$ & $14.05 \mathrm{bcd}$ & $6.87 \mathrm{~h}$ \\
\hline Lanelate & $1.96 \mathrm{a}$ & $1.92 \mathrm{c}$ & $5.05 \mathrm{~b}$ & $44.03 \mathrm{abc}$ & $11.23 \mathrm{a}$ & $0.82 \mathrm{a}$ & 15.30 ef & $3.63 \mathrm{~cd}$ & $7.51 \mathrm{a}$ & $5.38 \mathrm{fg}$ \\
\hline Navelate & $2.17 \mathrm{ab}$ & $2.05 \mathrm{c}$ & $4.89 \mathrm{~b}$ & $46.33 \mathrm{bcd}$ & $11.48 \mathrm{ab}$ & $0.84 \mathrm{ab}$ & $13.89 \mathrm{cde}$ & $3.60 \mathrm{bcd}$ & $6.01 \mathrm{a}$ & $5.85 \mathrm{~g}$ \\
\hline Salustiana & $2.24 \mathrm{ab}$ & $2.07 \mathrm{bc}$ & $4.87 \mathrm{~b}$ & $44.91 \mathrm{abcd}$ & $12.89 \mathrm{abc}$ & $1.34 \mathrm{cdef}$ & $9.86 \mathrm{abc}$ & $3.34 \mathrm{abc}$ & $7.60 \mathrm{ab}$ & $4.37 \mathrm{cde}$ \\
\hline Sanguinelli & $1.80 \mathrm{ab}$ & $3.59 \mathrm{~d}$ & $4.71 \mathrm{~b}$ & $44.99 \mathrm{abcd}$ & $10.38 \mathrm{a}$ & $1.71 \mathrm{f}$ & $6.07 \mathrm{a}$ & $3.06 \mathrm{ab}$ & $6.38 \mathrm{ab}$ & $8.04 \mathrm{i}$ \\
\hline Valencia & $2.74 \mathrm{ab}$ & $1.77 \mathrm{abc}$ & $5.12 \mathrm{~b}$ & $48.00 \mathrm{~cd}$ & $10.83 \mathrm{a}$ & $1.29 \mathrm{de}$ & $8.58 \mathrm{ab}$ & $3.64 \mathrm{bcd}$ & $8.75 \mathrm{ab}$ & $5.98 \mathrm{gh}$ \\
\hline W. Navel & $2.59 \mathrm{ab}$ & $1.75 \mathrm{abc}$ & $5.31 \mathrm{~b}$ & $41.52 \mathrm{ab}$ & $13.11 \mathrm{bc}$ & $1.25 \mathrm{~cd}$ & $10.75 \mathrm{abcd}$ & $3.28 \mathrm{abc}$ & $8.26 \mathrm{ab}$ & $5.23 \mathrm{defg}$ \\
\hline
\end{tabular}

Maturity index = SSC/TA $(\mathrm{SSC}=$ soluble solids concentration; TA = titratable acidity $)$. Color index $(\mathrm{CI}=1000 . \mathrm{a} / \mathrm{L} . \mathrm{b}$; Hunter parameters $)$

Within columns, values followed by the same letters did not differ significantly according to Fisher's protected least significant difference test $(P=0.05)$ 
Figure 1. Susceptibility to green (GM) and blue (BM) molds, according to disease incidence (\%) and pathogen sporulation (\%), of fifteen citrus cultivars artificially inoculated with Penicillium digitatum and $P$. italicum, respectively, and incubated at $20^{\circ} \mathrm{C}$ and $90 \% \mathrm{RH}$ for 10 days.

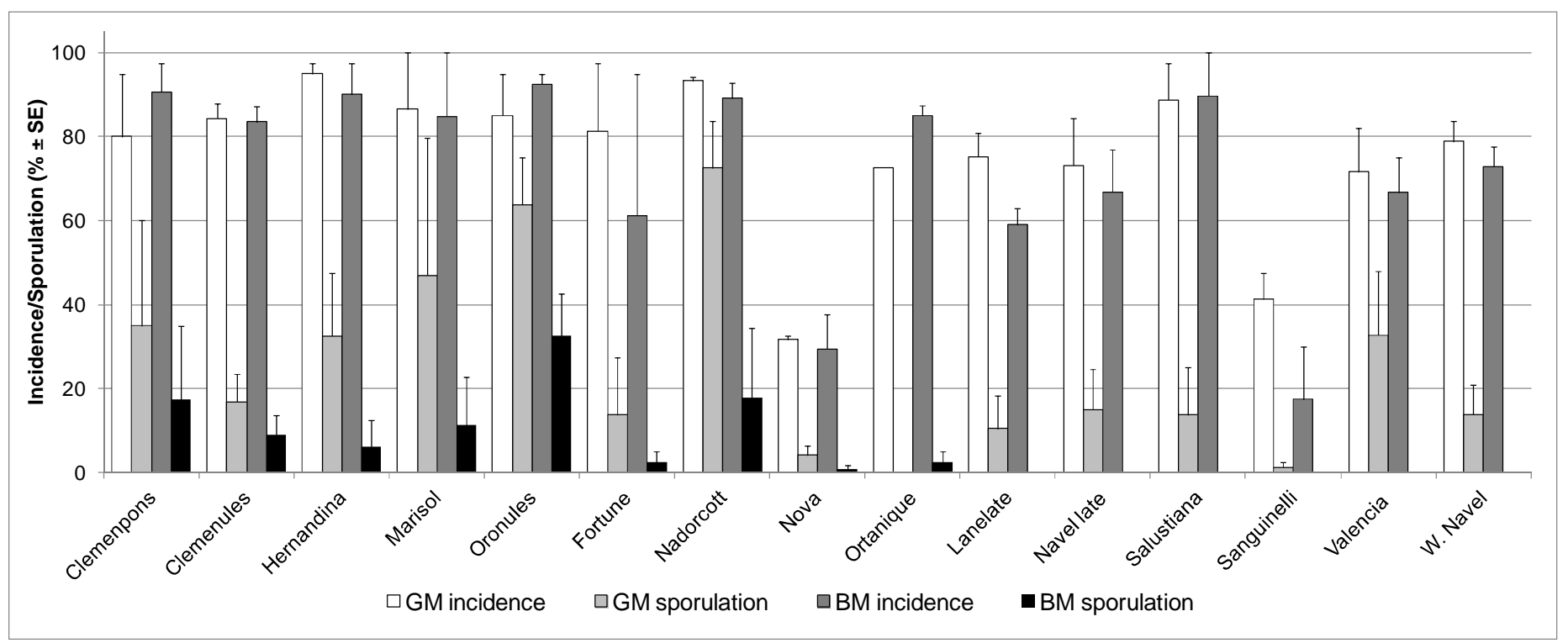


Figure 2. Disease severity rate (DSR, mm/day) of green (GM) and blue (BM) molds on fifteen citrus cultivars artificially inoculated with Penicillium digitatum and P. italicum, respectively, and incubated at $20^{\circ} \mathrm{C}$ and $90 \% \mathrm{RH}$ for 10 days.

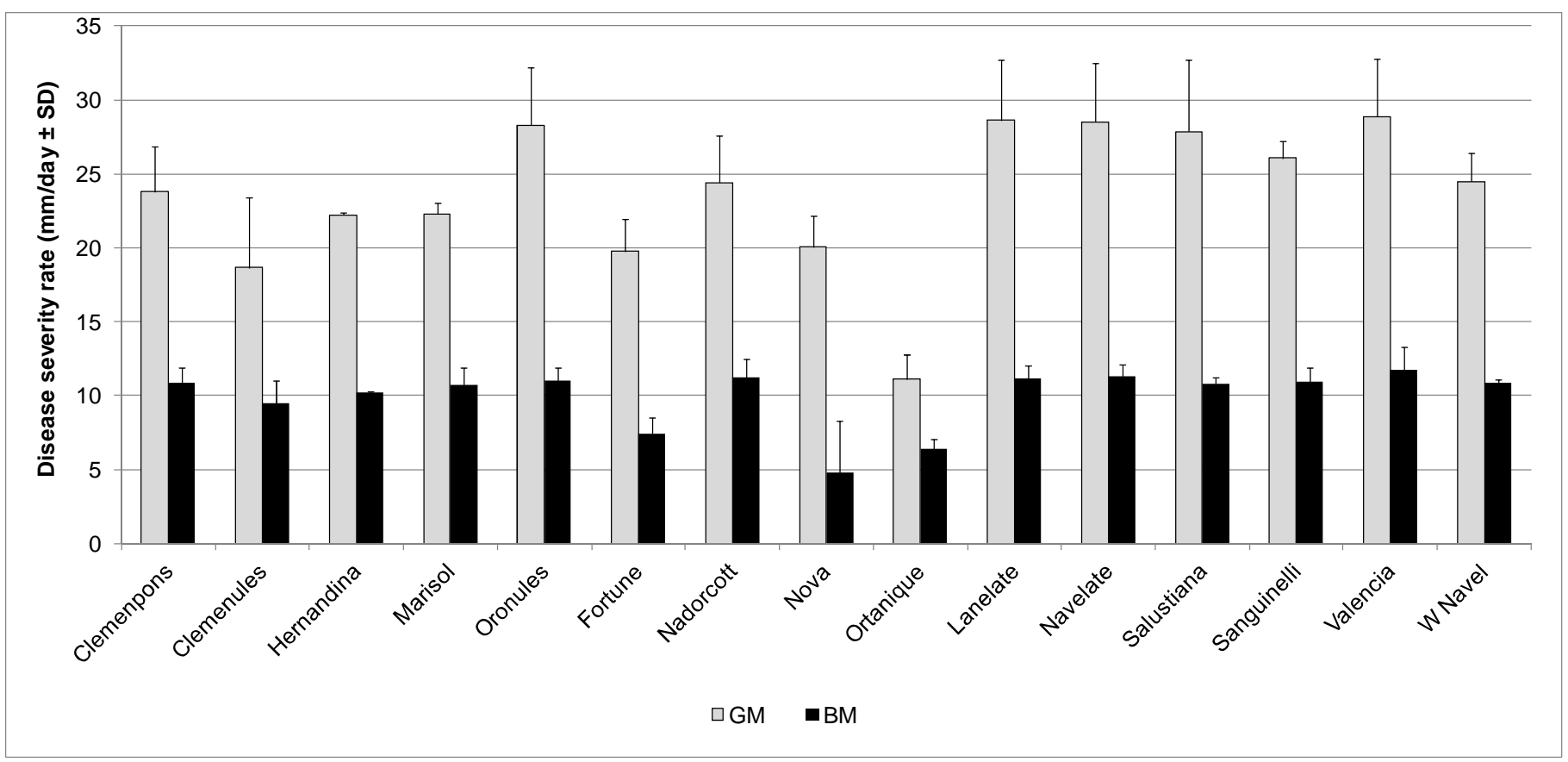


Cultivar susceptibility. Development of green and blue molds was evaluated on inoculated fruit by using the measurable parameters disease incidence $(\%)$ and severity (lesion diameter) and pathogen sporulation $(\%)$, and calculating other parameters (AUDPC, DSR, DI, and DCD) in order to have a better description of overall disease development. It is known that the occurrence of disease is determined by the relationship between the pathogen, the fruit host and the environmental conditions. In this study, the inoculum load and the environmental conditions were set as constant in order to isolate the effect of fruit host on disease development. For each cultivar, we intended to countervail the natural and seasonal variability associated with fruit growing conditions by repeating the trials for four different seasons.

Disease incidence is probably the most important parameter to account for the susceptibility of any fruit to a postharvest disease. Conidia of $P$. digitatum or $P$. italicum situated in peel wounds of mature fruit that rupture oil glands or penetrate into the albedo typically bring irreversible infection within $48 \mathrm{~h}$ at $20-25^{\circ} \mathrm{C}$ (Green, 1932; Kavanagh and Wood, 1967). Immature fruit, by contrast, have in the peel considerable amounts of preformed antifungal compounds such as citral or different flavonoids that interfere with fungal development and inhibit decay (Del Río and Ortuño, 2004). In addition, when citrus fruit are artificially inoculated following a methodology like that described here, both an abiotic (rind wounding) and a biotic stress (fungal infection) are produced that elicitate another line of defense comprising different induced resistance mechanisms such as accumulation of lignin or lignin-like polymers (Ismail and Brown, 1979), biosynthesis of phytoalexins like scoparone or scopoletin (Kim et al., 1991), or production of pathogenesis-related proteins like chitinases or glucanases (Pavoncello et al., 2001). Both preformed and induced defense responses are dependent on citrus genotype and the inherent capacity of each cultivar to use effectively these types of defense mechanisms is crucial to prevent the infection at the initial stage, and will determine the onset or failure of disease development. Incidence of green and blue molds revealed important differences among citrus cultivars $(P=0.000)$. The most resistant cultivars to get infected by $P$. digitatum and $P$. italicum after artificial inoculation were Nova and Sanguinelli and, in general, disease incidence 
was lower on oranges (except Salustiana) than mandarins (Fig. 1). Multiple range tests for incidence by cultivar (not shown) showed that Nova and Sanguinelli were significantly more resistant to green mold than the rest of cultivars, but differences among the rest of them were diffuse. On the contrary, according to blue mold incidence, the tested cultivars could be clearly divided into three groups with different susceptibility: Sanguinelli and Nova with high resistance; Lanelate, Fortune, Valencia, Navelate, and W. Navel with intermediate resistance; and all the clementines, the hybrid mandarin Ortanique, and the orange Salustiana with low resistance. When comparing the incidence of both molds, most of the cultivars were similarly susceptible to green and blue molds, except the mandarin Ortanique, for which blue mold incidence was slightly higher than that of green mold (Fig. 1).

On fruit with successful infections, disease severity as lesion diameter was measured daily for 10 days after inoculation and a curve representing severity by incubation time was obtained. After applying linear regression procedures, a line was obtained which slope can appropriately represent the rate of growth of the pathogen. This slope or DSR is an indicator of how quickly the pathogen grows once the infection has started. The average DSR for lesions caused by $P$. digitatum and $P$. italicum on citrus cultivars incubated at $20^{\circ} \mathrm{C}$ for 10 days was 23.8 and $10.1 \mathrm{~mm} /$ day, respectively. At this temperature, green mold grew faster than blue mold, however, blue mold can be more prevalent on fruit stored at $3-5^{\circ} \mathrm{C}$, the usual cold storage temperatures for oranges or mandarins. Different studies (Plaza et al., 2003, 2004) showed that P. italicum germinated and grew faster than $P$. digitatum at low temperatures and under drier conditions. It was observed in the present research that DSR values significantly differed among mandarin cultivars $(P=0.0102)$, being Oronules the cultivar in which green mold grew faster, while they were similar among orange cultivars $(P=0.6096)$. In general, DSR for green mold was higher on oranges and Oronules mandarins (>25 $\mathrm{mm} /$ day) than on the rest of mandarins $(10-25 \mathrm{~mm} /$ day). The cultivar with the lowest DSR for green mold was Ortanique (Fig. 2). Similarly, the lowest DSR for blue mold was observed on Nova, Ortanique, and Fortune mandarins. On the rest of cultivars, DSR for blue mold was higher and very similar among them (around $10 \mathrm{~mm} /$ day; Fig. 2). 
Figure 3. Susceptibility to green $(\mathrm{GM})$ and blue $(\mathrm{BM})$ molds, according to area under disease progress curve (AUDPC) and disease index (DI), of fifteen citrus cultivars artificially inoculated with Penicillium digitatum and P. italicum, respectively, and incubated at $20^{\circ} \mathrm{C}$ and $90 \% \mathrm{RH}$ for 10 days.

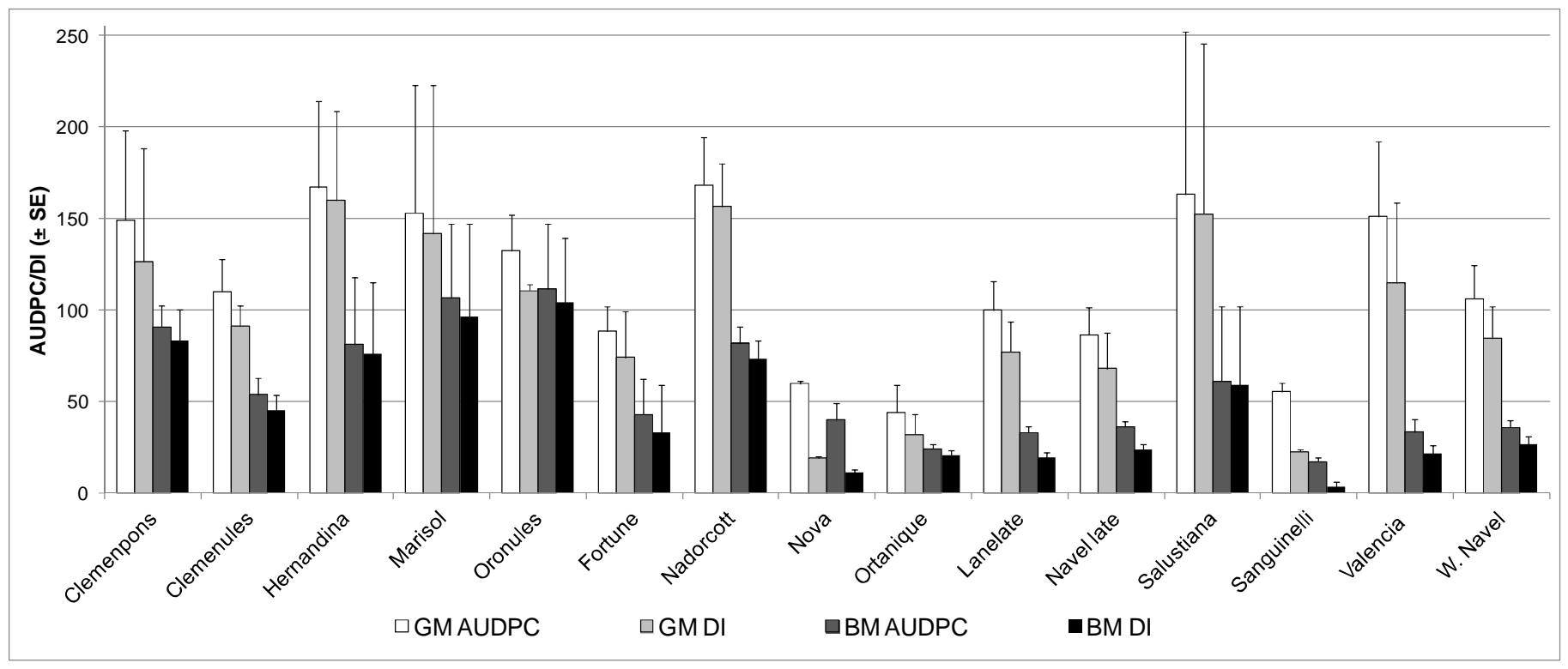


AUDPC is another parameter basically related to the severity of the disease, since it is calculated from the diameter of the lesion. It also takes into account the rate of disease development and how early the infection is successfully established and the pathogen starts its growth. The earlier the infection starts, and the faster the pathogen grows, the higher AUDPC values are. Nevertheless, AUDPC does not take into account the incidence of the disease. By introducing the index DI, both severity and incidence of the disease are taken into account. Based on their AUDPC, the most resistant citrus cultivars to green mold development were, in this order, Ortanique, Sanguinelli, and Nova, and the most susceptible were Salustiana, Hernandina, Nadorcott, Valencia, Clemenpons, Marisol, and Oronules (Fig. 3). In the case of blue mold, the most resistant were Sanguinelli, Ortanique, Valencia, Lanelate, Navelate, W. Navel, and Nova, and the most susceptible Marisol and Oronules mandarins. The index DI highlighted susceptibility differences among cultivars and strongly pointed Sanguinelli oranges as the most resistant cultivar to blue mold, and Sanguinelli and Nova as the most resistant to green mold (Fig. $3)$.

As the fungus grows and lesion size increases, aerial white mycelium develops in the center of the lesion and expands radially. Depending on the inoculum load and environmental factors $t$, sporulation begins after few days at usual room temperatures and forms the typical colored layer that gives their common name to the diseases (Palou, 2014). Fungal spores from fruit rotting in packinghouse facilities and storage rooms, or in any place during fruit transportation and marketing are massively transported by air currents and can easily contaminate the surrounding fruit. Therefore, sporulation is a crucial parameter for the spread of the disease, since it may result in the contamination of other fruits and a considerable increase of economic losses. In the present study, with fruit incubated at $20^{\circ} \mathrm{C}$, we observed that spores appeared on lesions infected by $P$. digitatum much earlier than on those infected by $P$. italicum. None of the oranges inoculated with $P$. italicum showed sporulation within 7 days after inoculation, and the percentage of sporulated fruit on the rest of cultivars was always lower than that of green mold, except on Ortanique hybrid mandarins, in which no green mold sporulation was observed and blue mold sporulation was very low. Nadorcott and Oronules were the cultivars showing a higher percentage of sporulation 
of green and blue molds, respectively (Fig. 1). Green mold sporulation was decreasingly observed on Marisol, Clemenpons, Hernandina, and Valencia. Clemenules, Fortune, and the rest of oranges (except Sanguinelli) showed a sporulation percentage around 15\%, and Nova, Sanguinelli and Ortanique $(0 \%)$ were the cultivars with the lowest sporulation percentages.

On oranges, although there were differences in the incidence of blue mold between cultivars, once the infection was established, blue mold development in terms of AUDPC, DSR, and sporulation percentage, was very similar among cultivars. It is remarkable that, except for Nova, Ortanique and Fortune, DSR for blue mold was virtually the same for all cultivars.

Table 2. Ranking of citrus cultivars susceptibility, from least susceptible to most susceptible, to green and blue molds according to the calculated parameter Disease Cube Diagonal (DCD).

\begin{tabular}{crlcrl}
\hline $\begin{array}{c}\text { Green mold } \\
\text { susceptibility } \\
\text { ranking }\end{array}$ & $\begin{array}{c}\text { Green mold } \\
\text { DCD value }\end{array}$ & $\begin{array}{c}\text { Blue mold } \\
\text { susceptibility } \\
\text { ranking }\end{array}$ & $\begin{array}{c}\text { Blue mold } \\
\text { DCD value }\end{array}$ \\
\hline $\begin{array}{c}\text { Nova } \\
\text { Sanguinelli }\end{array}$ & $67.84 \mathrm{a}$ & Sanguinelli & $25.42 \mathrm{a}$ \\
Ortanique & $69.43 \mathrm{ab}$ & Nova & $51.66 \mathrm{ab}$ \\
Lanelate & $112.86 \mathrm{abc}$ & Lanelate & $68.10 \mathrm{~b}$ \\
Navelate & $115.20 \mathrm{abc}$ & Valencia & $74.94 \mathrm{bc}$ \\
Fortune & $121.31 \mathrm{bcde}$ & Navelate & $77.20 \mathrm{bc}$ \\
Clemenules & $129.44 \mathrm{bcd}$ & W. Navel & $81.19 \mathrm{bc}$ \\
Valencia & $133.41 \mathrm{bcde}$ & Ortanique & $88.40 \mathrm{bcd}$ \\
W. Navel & $134.14 \mathrm{bcde}$ & Clemenules & $96.48 \mathrm{~cd}$ \\
Oronules & $171.30 \mathrm{cdef}$ & Salustiana & $112.31 \mathrm{cde}$ \\
Clemenpons & $173.64 \mathrm{cdef}$ & Hernandina & $123.61 \mathrm{de}$ \\
Marisol & $184.18 \mathrm{cdef}$ & Nadorcott & $124.42 \mathrm{de}$ \\
Salustiana & $190.17 \mathrm{def}$ & Marisol & $137.45 \mathrm{e}$ \\
Hernandina & $196.26 \mathrm{ef}$ & Clemenpons & $145.76 \mathrm{e}$ \\
Nadorcott & $206.64 \mathrm{e}$ & Oronules & $149.84 \mathrm{e}$ \\
\hline
\end{tabular}


Finally, in order to rank the overall susceptibility of cultivars to green and blue molds taking into account all three parameters that describe disease development (incidence, severity by means of AUDPC, and sporulation) the variable DCD was calculated. According to this parameter, the classification of cultivars from least to most susceptible is shown in Table 2. Although differences in DCD values among cultivars were rather gradual, a similar pattern followed by DCD for both green and blue molds could be established and hence the cultivars could be divided into three groups. Nova and Sanguinelli were the most resistant cultivars to both diseases, and a group with Salustiana, Nadorcott, and all mandarins except Clemenules, were the most susceptible to green and blue molds. Actual ranking of cultivars within this group of most susceptible cultivars was not the same for green and blue molds, but there were no significant differences among them in any case. The range of DCD values for cultivars with intermediate susceptibility was wider for green mold than blue mold. In this group, Ortanique mandarins showed a different position in the rank of susceptibility, with higher susceptibility to blue mold than green mold. In agreement with these results, a study carried out by Ortuño et al. (2011) with mature citrus fruits artificially inoculated with Penicillium digitatum showed that the degree of fungal development depended on the citrus species. Thus, grapefruits were more susceptible to green mold than lemons, oranges, clementines, and satsumas. They attributed the differences in susceptibility to differences in the composition of preformed antifungal compounds in the rind of each citrus species. For instance, they found high levels of the flavanones hesperidin in oranges, mandarins and satsumas and naringin in grapefruit, and of the flavanone hesperidin and the flavone diosmin in lemons. In contrast, Eckert and Eacks (1989) described a different order in the susceptibility of citrus species to postharvest diseases, and listed from more to less susceptible mandarins, lemons, oranges and grapefruits. In the present study differences were observed among cultivars within each citrus species group, which indicates that susceptibility is more specific to citrus cultivars rather than to citrus species. It was found that, in general, mandarins showed higher susceptibility than oranges, which would be in agreement with the classification by Eckert and Eacks (1989). Parental origin of the four hybrid mandarins in this study was not the same, and neither their susceptibility to green and blue molds. 
Nadorcott was much more susceptible to both diseases than the rest of hybrids, and its susceptibility was similar to that of the most susceptible clementines like Oronules and Marisol. On the contrary, Nova was the most resistant cultivar, at a similar level as Sanguinelli orange. Ortanique hybrid showed an intermediate susceptibility to blue mold, while it was among the most resistant cultivars to green mold. The susceptibility of Fortune hybrid to both molds was medium to low, and in both cases similar to that of the rest of oranges except Salustiana, which showed a high susceptibility similar to that of mandarins.

\section{Relationship between fruit quality parameters and cultivar susceptibility}

A Pearson analysis of correlations among the qualitative characteristics of all fifteen citrus cultivars and the development of green and blue molds (Table 3) showed that susceptibility of citrus fruit to both molds was positively correlated to rind deformation (negatively with rind firmness), and negatively correlated to peel oil release pressure and peel break resistance. The rest of quality parameters was not significantly correlated to susceptibility. These findings are in agreement with the results from previous studies with other commodities. For instance, susceptibility of apple cultivars to fungal pathogens was significantly correlated to quality parameters (Konstantinou et al., 2011). These authors observed that, while lesion diameter of disease caused by Penicillium expansum was negatively correlated to fruit firmness (tissue break resistance), none of the juice quality parameters assessed, namely $\mathrm{SSC}$, TA, or $\mathrm{pH}$, was correlated to susceptibility of apples to infection by P. expansum or Botrytis cinerea. 
Table 3. Pearson correlation coefficients $(r)$ among citrus fruit quality attributes and cultivar susceptibility to green $(\mathrm{GM})$ and blue $(\mathrm{BM})$ molds determined as disease incidence, pathogen sporulation, area under disease progress curve (AUDPC), and disease index (DI).

\begin{tabular}{|c|c|c|c|c|c|c|c|c|}
\hline $\begin{array}{l}\text { Fruit quality } \\
\text { parameters }\end{array}$ & $\begin{array}{c}\text { GM } \\
\text { incidence }\end{array}$ & $\begin{array}{c}\text { GM } \\
\text { sporulation }\end{array}$ & $\begin{array}{c}\text { GM } \\
\text { AUDPC } \\
\end{array}$ & GM DI & $\begin{array}{c}\mathbf{B M} \\
\text { incidence } \\
\end{array}$ & $\begin{array}{c}\text { BM } \\
\text { sporulation }\end{array}$ & $\begin{array}{c}\text { BM } \\
\text { AUDPC } \\
\end{array}$ & BM DI \\
\hline Deformation & $0,42 *$ & $0,41 *$ & $0,27 *$ & $0,32 *$ & $0,50 *$ & $0,45 *$ & $0,64 *$ & $0,64 *$ \\
\hline Peel break resistance & $-0,29 *$ & $-0,35 *$ & $-0,29 *$ & $-0,32 *$ & $-0,32 *$ & $-0,34 *$ & $-0,37 *$ & $-0,36 *$ \\
\hline Peel thickness & $-0,08$ & $-0,06$ & $-0,09$ & $-0,10$ & $-0,10$ & $-0,17$ & $-0,03$ & $-0,07$ \\
\hline Flavedo thickness & $-0,48$ & $-0,34$ & 0,05 & 0,00 & $-0,25$ & $-0,47$ & $-0,27$ & $-0,27$ \\
\hline Juice yield & $-0,18$ & $-0,05$ & $-0,02$ & $-0,07$ & $-0,12$ & 0,00 & 0,06 & 0,04 \\
\hline Juice SSC & 0,19 & $-0,20$ & $-0,16$ & $-0,06$ & 0,10 & 0,00 & $-0,04$ & $-0,02$ \\
\hline Juice TA & $-0,10$ & $-0,02$ & $-0,04$ & $-0,06$ & $-0,05$ & $-0,01$ & $-0,11$ & $-0,06$ \\
\hline Juice MI & 0,05 & $-0,18$ & $-0,10$ & $-0,06$ & $-0,05$ & $-0,07$ & 0,00 & $-0,05$ \\
\hline Juice $\mathrm{pH}$ & 0,10 & 0,01 & 0,15 & 0,14 & $-0,05$ & $-0,09$ & 0,14 & 0,05 \\
\hline Peel color & $-0,16$ & 0,01 & $-0,15$ & $-0,14$ & $-0,15$ & 0,10 & 0,08 & 0,00 \\
\hline Albedo $\mathrm{pH}$ & 0,05 & 0,82 & 0,33 & 0,22 & 0,03 & 0,32 & 0,75 & 0,46 \\
\hline Peel oil release pressure & $-0,52 *$ & $-0,52 *$ & $-0,53 *$ & $-0,57 *$ & $-0,60 *$ & $-0,48 *$ & $-0,58 *$ & $-0,61 *$ \\
\hline
\end{tabular}

Asterisks (*) indicate $r$ value significant at $P=0.05$. 
Table 4. Pearson correlation coefficients $(r)$ among orange fruit quality attributes and cultivar susceptibility to green $(\mathrm{GM})$ and blue $(\mathrm{BM})$ molds determined as disease incidence, pathogen sporulation, area under disease progress curve (AUDPC), and disease index (DI).

\begin{tabular}{|c|c|c|c|c|c|c|c|c|}
\hline $\begin{array}{l}\text { Fruit quality } \\
\text { parameters }\end{array}$ & $\begin{array}{c}\text { GM } \\
\text { incidence }\end{array}$ & $\begin{array}{c}\text { GM } \\
\text { sporulation }\end{array}$ & $\begin{array}{c}\text { GM } \\
\text { AUDPC }\end{array}$ & GM DI & $\begin{array}{c}\text { BM } \\
\text { incidence }\end{array}$ & $\begin{array}{c}\text { BM } \\
\text { sporulation }\end{array}$ & $\begin{array}{c}\text { BM } \\
\text { AUDPC }\end{array}$ & BM DI \\
\hline Deformation & 0,11 & 0,28 & 0,17 & 0,15 & 0,21 & 0,00 & 0,02 & 0,04 \\
\hline Peel break resistance & $-0,06$ & $-0,21$ & $-0,35$ & $-0,28$ & $-0,18$ & 0,00 & $-0,26$ & $-0,20$ \\
\hline Peel thickness & 0,22 & 0,14 & 0,25 & 0,22 & 0,10 & 0,00 & 0,12 & 0,05 \\
\hline Flaved o thickness & $-0,97 *$ & $-0,26$ & $-0,60$ & $-0,66$ & $-0,60$ & & $-0,49$ & $-0,52$ \\
\hline Juice yield & $-0,28$ & $-0,08$ & $-0,08$ & $-0,14$ & $-0,22$ & 0,00 & $-0,02$ & $-0,07$ \\
\hline Juice SSC & 0,21 & $-0,13$ & 0,01 & 0,06 & 0,21 & 0,00 & 0,24 & 0,22 \\
\hline Juice TA & $-0,31$ & 0,02 & 0,06 & $-0,02$ & $-0,19$ & 0,00 & 0,04 & 0,06 \\
\hline Juice MI & 0,30 & $-0,18$ & $-0,13$ & $-0,03$ & 0,12 & 0,00 & 0,05 & $-0,01$ \\
\hline Juice $\mathrm{pH}$ & 0,21 & $-0,02$ & 0,00 & 0,03 & 0,29 & & $-0,06$ & $-0,09$ \\
\hline Peel color & $-0,24$ & 0,02 & 0,13 & 0,01 & $-0,06$ & 0,00 & 0,09 & $-0,03$ \\
\hline Albedo pH & & & 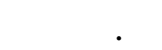 & . & & 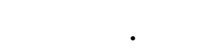 & . & . \\
\hline Peel oil release pressure & $-0,36$ & $-0,25$ & $-0,59 *$ & $-0,53 *$ & $-0,57$ & 0,00 & $-0,54 *$ & $-0,50 *$ \\
\hline
\end{tabular}


Table 5. Pearson correlation coefficients among mandarin fruit (quality attributes and cultivar susceptibility to green (GM) and blue (BM) molds determined as disease incidence, pathogen sporulation, area under disease progress curve (AUDPC), and disease index (DI).

\begin{tabular}{|c|c|c|c|c|c|c|c|c|}
\hline $\begin{array}{l}\text { Fruit quality } \\
\text { parameters }\end{array}$ & $\begin{array}{c}\text { GM } \\
\text { incidence }\end{array}$ & $\begin{array}{c}\text { GM } \\
\text { sporulation }\end{array}$ & $\begin{array}{c}\text { GM } \\
\text { AUDPC }\end{array}$ & GM DI & $\begin{array}{c}\text { BM } \\
\text { incidence }\end{array}$ & $\begin{array}{c}\text { BM } \\
\text { sporulation }\end{array}$ & $\begin{array}{c}\text { BM } \\
\text { AUDPC } \\
\end{array}$ & BM DI \\
\hline Deformation & $0,55^{*}$ & $0,44 *$ & $0,49 *$ & $0,53 *$ & $0,47 *$ & 0,17 & $0,58 *$ & $0,58 *$ \\
\hline Peel break resistance & $-0,48 *$ & $-0,42 *$ & $-0,26$ & $-0,38 *$ & $-0,25$ & $-0,30$ & $-0,27$ & $-0,27$ \\
\hline Peel thickness & $-0,11$ & $-0,07$ & $-0,13$ & $-0,14$ & $-0,13$ & $-0,17$ & $-0,02$ & $-0,07$ \\
\hline Flaved o thickness & $-0,23$ & $-0,06$ & 0,52 & 0,51 & 0,19 & $-0,30$ & 0,07 & 0,09 \\
\hline Juice yield & $-0,14$ & $-0,05$ & 0,01 & $-0,03$ & $-0,08$ & $-0,01$ & 0,09 & 0,08 \\
\hline Juice SSC & 0,09 & $-0,41 *$ & $-0,34$ & $-0,23$ & $-0,17$ & $-0,25$ & $-0,40 *$ & $-0,35$ \\
\hline Juice TA & 0,15 & 0,01 & $-0,14$ & $-0,07$ & 0,20 & 0,11 & $-0,08$ & $-0,01$ \\
\hline Juice MI & $-0,20$ & $-0,28$ & $-0,10$ & $-0,13$ & $-0,32$ & $-0,26$ & $-0,18$ & $-0,23$ \\
\hline Juice pH & 0,09 & 0,06 & 0,29 & 0,25 & $-0,23$ & 0,00 & 0,34 & 0,19 \\
\hline Peel color & $-0,29$ & $-0,12$ & $-0,30$ & $-0,29$ & $-0,44 *$ & $-0,11$ & $-0,14$ & $-0,24$ \\
\hline Albedo pH & 0,42 & 0,73 & 0,55 & 0,53 & 0,20 & 0,86 & $-0,03$ & 0,14 \\
\hline Peel oil release pressure & $-0,55 *$ & $-0,57 *$ & $-0,45 *$ & $-0,54 *$ & $-0,46 *$ & $-0,44$ & $-0,46 *$ & $-0,52 *$ \\
\hline
\end{tabular}

Asterisks $(*)$ indicate $r$ value significant at $P=0.05$ 
Pearson correlation coefficients were also calculated for the same variables, but separating oranges from the rest of citrus cultivars (Table 4). It was observed that in oranges, flavedo thickness was strongly and negatively correlated with green mold incidence, and peel oil release pressure was negatively correlated with AUDPC and DI for both green and blue molds, but there were no more significant correlations. Apparently, orange flavedo characteristics like thickness and peel oil release pressure were important to prevent and/or delay green mold disease. On the other hand, when Pearson correlation coefficients were calculated for the same variables, but only for mandarin cultivars (Table 5), it was observed that a higher amount of quality attributes significantly affected the susceptibility to disease. Rind deformation was positively correlated to all disease-defining parameters for both diseases except for blue mold sporulation. In other terms, softer fruit were more prone to disease than harder fruit. The fact that blue mold sporulation was not correlated to any quality parameter was probably due to the general lower values of the sporulation percentage. Peel break resistance was negatively correlated with green mold incidence, sporulation of $P$. digitatum and DI for green mold, but not with AUDPC or other diseasedefining parameters on mandarins. Therefore, peel hardness seemed to be determinant to prevent the onset of green mold, and disease incidence and pathogen sporulation were higher on soft fruit. However, once the infection was established, peel hardness did not influence the growth of $P$. digitatum. In contrast, none of the quality parameters was significantly correlated to susceptibility to blue mold on mandarin cultivars (Table 5). Green mold sporulation and blue mold AUDPC were negatively correlated to juice SSC, and blue mold incidence was negatively correlated to peel color (Table 5). It seems contradictory that lower SSC, that normally are indicative of more immature fruit, were associated with higher susceptibility. It is known that peel wound contamination of immature citrus fruit by spores of $P$. digitatum or $P$. italicum is rarely followed by successful infection establishment and disease development because of a variety of complex biochemical mechanisms triggered by the fruit host that lead to natural disease resistance. Typically, this resistance is gradually lost during fruit maturation and aging (Palou, 2014). Internal maturity-related changes have been proposed as key factors determining the onset of susceptibility to rot pathogens also in 
other fruits (Sitterly and Shay, 1960). On the other hand, the fact that peel color was negatively correlated to blue mold incidence might be the consequence of the higher susceptibility of more mature fruit to disease, since natural higher CI on oranges and mandarins are indicative of more intense orange color and less green shades.

In this study, some of the most commercially important orange and mandarin cultivars in Spain and worldwide were described based on their quality parameters and their relative susceptibility to green and blue molds. Availability of a rank of these citrus cultivars according to their susceptibility to major postharvest diseases, and knowledge about what easy-measurable peel characteristics better correlate to disease susceptibility, could be useful tools in integrated disease management programs to discriminate among fruit sets in order to tailor the disease control strategies to be applied in the packinghouse.

\section{Acknowledgements}

Mr. Federico Izquierdo from Fontestad S.A. (Montcada, València) is gratefully acknowledged for providing fruit. This work was partially funded by the Spanish 'Ministerio de Educación y Ciencia' (MEC; project AGL2004-05271) and the European Union (FEDER Program). Clara Montesinos-Herrero's doctorate program was supported by the IVIA. In memory of Dr. Miguel Ángel del Río, for his unconditional friendship, guidance and support.

\section{Literature cited}

Afek, U., Sztejnberg, A., 1988. Accumulation of scoparone, a phytoalexin associated with resistance of citrus to Phytophthora citrophthora. Phytopathology 78, $1678-1682$.

Del Río, J.A., Ortuño, A., 2004. Biosynthesis of flavonoids in citrus and its involvement in the antifungal defense mechanisms. In: Dris, R., Niskanen, R., Jain, S.M. (Eds.), Crop Management and Postharvest Handling of Horticultural Products. Science Publishers, Enfield, NH, USA, pp. 185-221. 
Eckert, J.W., Eaks, I.L., 1989. Postharvest disorders and diseases of citrus fruits. In: Reuter, W., Calavan, E.C., Carman, G.E. (Eds.), The Citrus Industry. DANR, University of California Press, Berkeley, CA, USA, pp. 179-260.

Gardner, J.M., Kono, Y., and Chandler, J.L. 1986. Bioassay and hostselectivity of Alternaria citri toxins affecting rouge lemon and mandarins. Physiological and Molecular Plant Pathology 29, 293 304.

Green, F.M., 1932. The infection of oranges by Penicillium. Journal of Pomology and Horticultural Science 10, 184-215.

Jiménez-Cuesta, M., Cuquerella, J., and Martínez-Jávega, J.M. 1981. Determination of a color index for Citrus fruit degreening. Proceedings of the International Society of Citriculture 2, $750-753$.

Kavanagh, J.A., Wood, R.K.S., 1967. The role of wounds in the infection of oranges by Penicillium digitatum Sacc. Annals of Applied Biology 60, 375-383.

Kim, J.J., Ben-Yehoshua, S., Shapiro, B., Henis, Y., Carmeli, S., 1991. Accumulation of scoparone in heat-treated lemon fruit inoculated with Penicillium digitatum Sacc. Plant Physiol. 97, 880-885.

Konstantinou, S., Karaoglanidis, G.S., Bardas, G. A., Minas, I.S., Doukas, E., and Markoglou, A.N. 2011. Postharvest fruit rots of apple in Greece: Pathogen incidence and relationships between fruit quality parameters, cultivar susceptibility, and patulin production. Plant Disease 95, 666-672.

Ismail, M.A., Brown, G.E. 1979. Postharvest wound healing in citrus fruit: Induction of phenylalanine ammonia-lyase in injured 'Valencia' orange flavedo. Journal of the American Society for Horticultural Science 104, 126-129.

McKinney, H.H. 1923. Influence of soil temperature and moisture on infection of wheat seedlings by Helmintosporium sativum. Journal of Agricultural Resource 26, 195-218.

Montesinos-Herrero, C., del Río, M.A., Pastor, C., Brunetti, O., Palou, L., 2009. Evaluation of brief potassium sorbate dips to control postharvest penicillium decay on major citrus species and cultivars. Postharvest Biology and Technology 52, 117-125. 
Montesinos-Herrero, C., del Río, M.A., Rojas-Argudo, C., Palou, L., 2012. Short exposure to high $\mathrm{CO}_{2}$ and $\mathrm{O}_{2}$ at curing temperature to control postharvest diseases of citrus fruit. Plant Disease 96, 423-430.

Moscoso-Ramírez, P.A., Montesinos-Herrero, C., Palou, L., 2013 a. Characterization of postharvest treatments with sodium methylparaben to control citrus green and blue molds. Postharvest Biology and Technology 77, 128-137.

Moscoso-Ramírez, P.A., Montesinos-Herrero, C., Palou, L., 2013 b. Control of citrus postharvest penicillium molds with sodium ethylparaben. Crop Protection 46, 44-51.

Ortuño, A., Díaz, L., Álvarez, N., Porras, I., García-Lidón, A., Del Río, J. A. 2011. Comparative study of flavonoid and scoparone accumulation in different Citrus species and their susceptibility to Penicillium digitatum. Food Chemistry 125, $232-239$.

Palou, L., 2014. Penicillium digitatum, Penicillium italicum (Green mold, Blue mold). In: Bautista-Baños, S. (Ed.), Postharvest Decay. Control Strategies. Academic Press, Elsevier Inc., London, UK, pp. 45-102.

Palou, L., Smilanick, J.L., Usall, J., Viñas, I., 2001. Control of postharvest blue and green molds of oranges by hot water, sodium carbonate, and sodium bicarbonate. Plant Disease 85, 371-376.

Palou, L., Usall, J., Muñoz, J.A., Smilanick, J.L., Viñas, I., 2002. Hot water, sodium carbonate, and sodium bicarbonate for the control of postharvest green and blue molds of clementine mandarins. Postharvest Biology and Technology 24, 93-96.

Pavoncello, D., Lurie, S., Droby, S., Porat, R., 2001. A hot water treatment induces resistance to Penicillium digitatum and promotes the accumulation of heat shock and pathogenesis-related proteins in grapefruit flavedo. Physiologia Plantarum 111, 17-22.

Peever, T.L., Olsen, L., Ibáñez, A., Timmer, L.W. 2000. Genetic differentiation and host specific among populations of Alternaria spp. causing brown spot of grapefruit and tangerine $\mathrm{x}$ grapefruit hybrids in Florida. Physiopathology 90, $407-414$.

Plaza, P., Usall, J., Teixidó, N., and Viñas, I. 2003. Effect of water activity and temperature on germination and growth of Penicillium digitatum, $P$. italicum and Geotrichum candidum. Journal of Applied Microbiology 94, 549 - 554. 
Plaza, P., Usall, J., Teixidó, N., and Viñas, I. 2004. Effect of water activity and temperature on competing abilities of common postharvest citrus fungi. International Journal of Food Microbiology $90,75-82$.

Reis, R.F., Almeida, T.F. De, Stuchi, E.S., Goes, A. De. 2007. Susceptibility of citrus species to Alternaria alternata, the causal agent of the Alternaria brown spot. Scientia Horticulturae 113, $336-$ 342.

Sitterly, W.R. Shay, J.R. 1960. Physiological factors affecting the onset of susceptibility of apple fruit to rotting by fungus pathogens. Phytopathology 50, $91-93$.

Shaner, E. Finney, R.E. (1977). The effect of nitrogen fertilization on the expression of slow-mildewing resistance in Knox wheat. Phytopathology, 67: 1051-1056.

Smilanick, J.L., Brown, G.E., Eckert, J.W., 2006. The biology and control of postharvest diseases. In: Wardowski, W.F., Miller, W.M., Hall, D.J., Grierson, W. (Eds.), Fresh Citrus Fruits, 2nd ed. Florida Science Source, Inc., Longboat Key, FL, USA, pp. 339-396.

Tugwell, B.L., Moulds, G. 1999. A guide to testing Citrus for potential rind injury. In: Citrus Handling Guide. ISBN: 0730852458. South Australian Research and Development Institute, Adelaide, Australia. 
Chapter 7

224 


Green and blue molds, caused by Penicillium digitatum and P. italicum, respectively, are the major postharvest diseases of citrus fruit, causing the most important economic losses during citrus commercialization. Application of fungicides after harvest has been shown to provide the most effective control. For decades, imazalil (IMZ), thiabendazol, and sodium o-phenylphenate have been the most commonly used fungicides worldwide for managing green and blue molds of citrus (Bus et al., 1991; Smilanick et al., 2006). Shortage of other synthetic fungicides with different modes of action has forced the industry to continuously use the same active ingredients, which has caused the rise of resistant strains of the pathogens. In addition, this problem is currently increasing due to the demand by citrus fruit distributors of maximum residue levels (MRLs) lower than those established by the current legislation (Palou, 2014).

The objective of the present thesis was to find alternative disease control treatments to be used as standalone treatments for organic markets, or in combination with synthetic fungicides in order to improve their efficacy at the restricted doses and hence reduce or slow down the development of resistant strains of the pathogens in the citrus postharvest industry.

Among the alternatives tested, dip treatments with potassium sorbate (PS) or sodium benzoate (SB) were the most readily applicable. This kind of treatments with low or no use of conventional fungicides is very demanded by general consumers and especially by most fruit distributors in the EU and worldwide. In addition, the different mode of action of SB and PS, compared to that of synthetic fungicides, could be an important additional tool to hinder the proliferation of strains of $P$. digitatum and $P$. italicum resistant to IMZ, which is at present a common important issue in most citrus packinghouses. In this sense, the use of these regulated food additives or generally regarded as safe (GRAS) compounds would allow the fight against resistances without the addition of other synthetic fungicides in the packinghouse disease management program. It is important to note, regarding this issue, that nowadays many important fruit distributors and large supermarket chains are also limiting the total number of synthetic active ingredients that can be present on/in exported citrus fruit. The postharvest treatments with aqueous solutions of SB or PS tested in this study, including those applied at temperatures as high as 
$50^{\circ} \mathrm{C}$, are currently feasible to be used at the commercial level in many modern Spanish or worldwide citrus packinghouses, with no need to change the established postharvest handling procedures. After the laboratory and small-scale trials with artificially inoculated fruit conducted as part of this thesis, which allowed the selection of the best application conditions, large-scale trials in citrus packinghouses with naturally infected fruit should be conducted to confirm the potential of SB and PS as commercial treatments against green and blue molds. As clearly shown by the obtained results and conveniently discussed in each corresponding chapter, the effectiveness of these food additives is variable and highly dependent on the treated citrus cultivars. Whenever the application of these substances is not effective enough to control decay satisfactorily, mainly due to very high inoculum loads or very susceptible citrus cultivars, combinations with control methods other than synthetic fungicides should be tested in order to improve SB and PS efficacy and offer alternative treatments for markets with zero tolerance to fungicide residues. It was found in this work that, at least in the case of PS, the application could be followed by a low pressure water rinse to avoid any damage on the skin of long-term stored sensitive citrus cultivars. Presumably, enough PS residues are still present in rind wounds after rinsing that can protect treated fruit against infections.

Another novel method evaluated in this thesis to lower decay that showed acceptable efficacy at the laboratory scale was the use of physical treatments such as brief fruit exposure to high $\mathrm{CO}_{2}$ or $\mathrm{O}_{2}$ atmospheres at curing temperatures. Exposure of citrus fruit to $15 \mathrm{kPa} \mathrm{CO}_{2}$ for $24 \mathrm{~h}$ or 30 $\mathrm{kPa} \mathrm{O}_{2}$ for $48 \mathrm{~h}$ at $33^{\circ} \mathrm{C}$ can be a convenient measure to inhibit green and blue molds after harvest. In general, treatments lacked persistence, but a marked inhibition was observed on fruit incubated for up to 7 days at $20^{\circ} \mathrm{C}$, which is a reasonable shelf-life period for domestic or, in the case of Spain, European export markets, especially taking into account that a nontoxic and residue-free antifungal treatment was applied that could open opportunities to conquer new and more profitable export markets. Furthermore, these treatments may be a suitable alternative to reduce the effective curing times of 65 to $72 \mathrm{~h}$ and thus facilitate the commercial implementation of curing treatments for citrus, which has been repeatedly found as one of the most effective methods to control 
penicillium molds (Ben-Yehoshua, 2005; Zhang and Swingle, 2005). Although the commercial feasibility of heated gaseous treatments in the conventional citrus industry is questionable due to treatment costs and the effectiveness, persistence, and availability of existing fungicides, these alternative treatments might be a useful tool to be considered in particular cases. Exposure to high $\mathrm{CO}_{2}$ or $\mathrm{O}_{2}$ leaves no chemical residues on fruit, which enables treated citrus fruit to be potentially traded as organic, considerably increasing the value of the commodity. Higher prices of the final product achieved by compliance with organic fruit production or specific 'green' markets may counteract the cost of establishing and using such postharvest treatments, especially when appropriate facilities are already available for citrus degreening or insecticidal quarantine treatments. In an integrated approach, the effectiveness and persistence of these treatments might be enhanced by combining them with other nonpolluting treatments, like for instance dips in aqueous solutions of GRAS compounds such as sodium carbonate, which are known for improving the performance of curing (Plaza et al., 2004). In the present thesis, when short gaseous treatments were preceded by selected PS dip treatments, very good control of green and blue molds was achieved. Of interest for future research, new gaseous combinations and also new combinations of gaseous exposure with other physical or chemical alternative methods should be tested on citrus to increase disease control effectiveness.

In a similar line of research, ammonia fumigations for $6 \mathrm{~h}$ at $22^{\circ} \mathrm{C}$ with two applied dosages of $3000 \mu \mathrm{L} \mathrm{L}^{-1}$ of ammonia, injected initially and again $2 \mathrm{~h}$ later, satisfactorily controlled green and blue molds on oranges and lemons. Combinations with low doses of IMZ were synergistic and allowed to lower the fungicide concentration without losing efficacy. IMZ can be applied immediately after harvest by drenching fruit within harvest bins with aqueous IMZ solutions. Subsequent ammonia fumigation on fruit arrival to the packinghouse may be a feasible practice. However, several important issues must be addressed before using ammonia as a fumigant. Anhydrous ammonia is classified by the US Department of Transportation as nonflammable (Anon., 2006). However, ammonia vapor in high concentrations (16 to 25 percent by weight in air) will burn, although it is difficult to ignite and will not support combustion after the ignition source is withdrawn. It was 
observed in early research that ammonia fumigation and ethylene degreening were compatible (Roistacher et al., 1957; Leggo and Seberry, 1964). Ammonia fumigation could be applied within degreening chambers, either before, after, or perhaps during ethylene degreening, and the treatment would not greatly prolong the duration of fruit exposure in the chambers. In the present study, we employed short exposures and the temperatures used during degreening in order to facilitate their combined use. The existing degreening chambers, present in most of the packinghouses in California and Spain, would need to be modified to contain the gas safely and resist corrosion. Ammonia, especially in the presence of moisture, reacts with and might corrode copper, zinc, and many alloys (Anon., 2006). Only wood, iron, steel, certain rubbers and plastics, and specific nonferrous alloys resistant to ammonia should be used. In order to establish a standardized procedure to employ ammonia fumigation, further studies on the optimal dosages and methods of application of ammonia gas are needed to validate the method for different citrus species and cultivars, and also to account for the fruit load factor within fumigation chambers. Gunther et al. (1959) suggested that the use of fiberboard cartons, which are now the most popular packaging material, should be avoided unless the amount of ammonia applied was increased to compensate for their large ammonia sorption capacity. Moreover, safe entry into these chambers once ammonia fumigation is complete requires evaluation; since rapid sorption of ammonia occurs, atmospheric release of ammonia may be minimal, although it is likely that entrapment of the remaining gas would be required. Occasionally, entrapment of sulfur dioxide gas remaining after fumigation of table grapes is done using an alkaline solution in an airwasher (Nelson, 1991). Similar air scrubbing could be done with an acidic solution to entrap remaining ammonia after fumigation before the chambers are opened.

As demonstrated by results from this thesis and has also been pointed out by other workers (Schirra et al., 2011; Valencia-Chamorro et al., 2011; Palou, 2014), and in contrast to what typically happens with synthetic fungicides, the effectiveness of many physical, chemical or biological alternative nonpolluting treatments is greatly dependent on citrus species and cultivar. Because of their mode of action, the effectiveness of these 
treatments usually varies with the natural susceptibility of treated fruit to penicillium decay. Although all commercial citrus species and cultivars are susceptible to be infected and decayed by $P$. digitatum or P. italicum (Eckert and Eaks, 1989), there is a gradation of relative susceptibility according to different physical and biochemical characteristics of the fruit. Therefore, the relative susceptibility to green and blue molds of the most important commercial citrus varieties cultivated in Spain was assessed in this thesis, and the correlation between fruit quality parameters and susceptibility was established. Having a rank of these citrus cultivars according to their susceptibility to postharvest diseases could be useful in integrated disease management programs to discriminate among fruit sets in order to tailor the control strategies to be applied in the packinghouse for particular cases and markets. Moreover, being able to measure peel characteristics that correlate to susceptibility could be an easy tool to use in the prediction of fruit susceptibility to diseases.

\section{Literature cited}

Anon. 2006. Ammonia as a Refrigerant. Position Document of the Board of Directors, American Society of Heating, Refrigerating and AirConditioning Engineers, Inc. Atlanta, Georgia. http://www.ashrae.org/docLib/200622793710_347.pdf

Ben-Yehoshua, S., (Ed), 2005. Environmentally Friendly Technologies for Agricultural Produce Quality. CRC Press, Taylor and Francis Group, Boca Raton, FL, USA, 534 pp.

Bus VG, Bongers AJ and Risse LA. 1991. Occurrence of Penicillium digitatum and $P$. italicum resistant to benomyl, thiabendazole and imazalil on citrus fruit from different geographic origins. Plant Disease 75, 11, 1098-1100.

Eckert JW and Eaks IL. 1989. Postharvest disorders and diseases of citrus fruits. In: Reuter, W., Calavan, E.C., Carman, G.E. (Eds.), The Citrus Industry. DANR, University of California Press, Berkeley, CA, USA, pp. 179-260.

Gunther FA, Blinn RC, Kolbezen MJ, Conkin RA, Wilson CW. 1959. Fungicides for package foods, sorption of ammonia by fruits, 
vegetables, eggs, and fiberboard in dynamic systems. J. Agric. Food Chem. 7, 496-502.

Leggo D and Seberry JA. 1964. Ammonia fumigation for reducing green mould wastage in oranges during ethylene degreening. Austral. J. Exp. Agric. Anim. Husb. 4, 173-177.

Nelson KE. 1991. Quality and preservation of fruits. In: Eskin, N.A.M. (Ed.), The grape. Boca Raton, Florida: CRC Press, pp. 125-167.

Palou L. 2014. Penicillium digitatum, Penicillium italicum (Green Mold, Blue mold). In: Bautista-Baños, S. (ed.), Postharvest Decay. Control Strategies. 1st ed. Academic Press, Elsevier. London, UK. pp. 45-102.

Plaza P, Usall J, Torres R, Abadias M, Smilanick JL and Viñas I. 2004. The use of sodium carbonate to improve curing treatments against green and blue moulds on citrus fruits. Pest Manag. Sci. 60,815-821.

Roistacher CN, Klotz LJ and Eaks IL. 1957. Ammonia gas used in citrus packing plants as fumigant for control of blue-green mold on Valencias, navels and lemons. Calif. Agric. 11, 11-12.

Schirra M, D’Aquino S, Cabras P and Angioni A. 2011. Control of postharvest diseases of fruit by heat and fungicides: efficacy, residue levels, and residue persistence. A review. Journal of Agricultural and Food Chemistry 59, 8531-8542.

Smilanick JL, Brown GE and Eckert JW. The biology and control of postharvest diseases. In: Fresh citrus fruits, 2nd edition. Wardowski WF, Miller WM, Hall DJ, Grierson W (editors). Longboat Key, FL, USA: Florida Science Source Inc.; 2006: pp. 339-396.

Valencia-Chamorro SA, Palou L, del Río MA and Pérez-Gago MB. 2011a. Antimicrobial edible films and coatings for fresh and minimally processed fruits and vegetables: a review. Critical Reviews in Food Science and Nutrition 51, 872-900.

Zhang J and Swingle PP. 2005. Effects of curing on green mold and stem-end rot of citrus fruit and its potential application under Florida packing system. Plant Disease 89, 834-840. 
CONCLUSIONS 



\section{GENERAL CONCLUSIONS}

1. Sodium benzoate (SB) alone or combined with low doses of imazalil (IMZ) showed high efficacy for the control of citrus green and blue molds, caused by Penicillium digitatum and $P$. italicum, respectively. Stand-alone dip treatments for $60 \mathrm{~s}$ with $3 \%(\mathrm{w} / \mathrm{v}) \mathrm{SB}$ heated above $50^{\circ} \mathrm{C}$ satisfactorily controlled green and blue mold on oranges, even when treated fruit were cold-stored. However, on mandarins and lemons, the combination of SB with low doses of $\mathrm{IMZ}$ was necessary to reduce disease incidence to commercially acceptable levels.

2. Treatment conditions of $62^{\circ} \mathrm{C}$ and 30 or $60 \mathrm{~s}$ were appropriate for satisfactory control of both citrus green and blue molds with $3 \%$ potassium sorbate (PS) aqueous solutions as part of an alternative integrated postharvest decay control program. These non-phytotoxic conditions would allow a reduction in the immersion time to at least half that required at temperatures of approximately $40^{\circ} \mathrm{C}$ and make PS treatments more feasible for the industry, particularly by allowing the use of smaller tanks that would save time, material costs, and space in the packinghouses.

3. A synergistic effect between PS and IMZ treatments was found when they were applied on oranges previously inoculated with $P$. digitatum. Compatibility and benefits from the integration of PS and IMZ treatments were also observed in semi-commercial trials with oranges and clementines. This integration allowed a considerable reduction of IMZ concentration without losing effectiveness for green mold control.

4. A simple, rapid, and accurate spectrophotometric method adapted from a known reaction with thiobarbituric acid was developed to determine residues of PS in citrus fruit based on blended whole fruit. Compared to a standard HPLC method, the spectrophotometric method is more convenient, easy, and rapid.

5. The amount of PS residues in citrus fruit increased with temperature and concentration of the treatment solution. A brief water rinse 
almost completely removed the residues of PS when applied promptly after treatment. However, PS migrated rapidly into the fruit rind and residue removal was not complete even when a highpressure water wash was used. PS residue levels in fruit decreased during storage at $15^{\circ} \mathrm{C}$ to approximately one-half the initial residue concentration after 5 or 6 days, and then remained relatively constant.

6. Exposure of citrus fruit to $15 \mathrm{kPa} \mathrm{CO}_{2}$ for $24 \mathrm{~h}$ or $30 \mathrm{kPa} \mathrm{O}_{2}$ for $48 \mathrm{~h}$ at $33^{\circ} \mathrm{C}$ effectively controlled both green and blue molds after 7 days of incubation at $20^{\circ} \mathrm{C}$, with incidence reductions from 73 to $100 \%$, but control of both diseases was minimal after 15 days. There was a synergistic effect between high $\mathrm{CO}_{2}$ or $\mathrm{O}_{2}$ and exposure temperature. Efficacy of treatments was highly cultivar dependant.

7. Combined treatments of $3 \%$ PS dips followed by exposure to $15 \mathrm{kPa}$ $\mathrm{CO}_{2}$ or $30 \mathrm{kPa} \mathrm{O}$ at $33^{\circ} \mathrm{C}$ for $24 \mathrm{~h}$ were synergistic and consistently reduced the incidence of green mold more than each treatment alone on commercially important citrus cultivars stored for either 7 days at $20^{\circ} \mathrm{C}$ or 28 days at $5^{\circ} \mathrm{C}$.

8. Fumigation of citrus fruit with two applied dosages of $3000 \mu \mathrm{L} / \mathrm{L}$ of ammonia, that was injected initially and again $2 \mathrm{~h}$ later, effectively controlled postharvest green and blue molds. Generally, it controlled blue mold better than green mold, and it was more effective on oranges than on lemons. The inhibitory activity of ammonia increased as the concentration applied increased and a double injection of ammonia further improved its effectiveness.

9. The combination of IMZ treatment followed by ammonia fumigation was usually additive or synergistic in effectiveness to control green mold. Using such combination, the disease was effectively controlled with IMZ concentrations as much as 50 times lower than those used commercially.

10. Quality attributes of the most important commercial citrus species and cultivars in Spain, namely, 'Clemenpons', 'Clemenules', 'Hernandina', 'Marisol', 'Oronules', 'Fortune', 'Nadorcott', 'Nova', 'Ortanique', 'Lanelate', 'Navelate', 'Salustiana', 'Sanguinelli', 
'Valencia', and 'Washington Navel' were assessed. External quality attributes such as peel firmness, thickness, and oil release pressure were clearly different on oranges and mandarins.

11. Ranking of citrus cultivar susceptibility to green mold from less to more susceptible was the following: 'Nova', 'Sanguinelli', 'Ortanique', 'Lanelate', 'Navelate', 'Fortune', 'Clemenules', 'Valencia', 'W. Navel', 'Oronules', 'Clemenpons', 'Marisol', 'Salustiana', 'Hernandina', and 'Nadorcott'.

12. Ranking of citrus cultivar susceptibility to blue mold from less to more susceptible was the following: 'Sanguinelli', 'Nova', 'Lanelate', 'Fortune', 'Valencia', 'Navelate', 'W. Navel', 'Ortanique', 'Clemenules', 'Salustiana', 'Hernandina', 'Nadorcott', 'Marisol', 'Clemenpons', and 'Oronules'.

13. Susceptibility of citrus fruit to green and blue molds was mostly correlated to peel characteristics, and not to juice or color properties. Susceptibility was positively correlated to peel deformation, and negatively correlated to peel oil release pressure and peel break resistance. 